\title{
The evolution of the Ascomycota - new insights from Mesozoic and Cenozoic amber fossils
}

\author{
Dissertation \\ zur Erlangung des mathematisch-naturwissenschaftlichen Doktorgrades \\ "Doctor rerum naturalium" \\ der Georg-August-Universität Göttingen
}

im Promotionsprogramm Geowissenschaften

der Georg-August University School of Science (GAUSS)

vorgelegt von

Christina Beimforde

aus Lohne

Göttingen 2013 


\section{Betreuungsausschuss:}

PD Dr. Alexander R. Schmidt, Courant Forschungszentrum Geobiologie, Arbeitsgruppe "Evolution der Landpflanzen und Entwicklung der terrestrischen Ökosysteme", GeorgAugust-Universität Göttingen

Prof. Dr. Joachim Reitner, Geowissenschaftliches Zentrum, Abteilung Geobiologie, Georg-August-Universität Göttingen

\section{Mitglieder der Prüfungskommission:}

Referent:

PD Dr. Alexander R. Schmidt, Courant Forschungszentrum Geobiologie, Arbeitsgruppe "Evolution der Landpflanzen \& Entwicklung der terrestrischen Ökosysteme", GeorgAugust-Universität Göttingen

Korreferent:

Prof. Dr. Joachim Reitner, Geowissenschaftliches Zentrum, Abteilung Geobiologie, Georg-August-Universität Göttingen

Dr. habil. Heinrich Dörfelt, Mikrobielle Phytopathologie und Institut für Ökologie, Friedrich-Schiller-Universität Jena

JProf. Dr. Daniel J. Jackson, Courant Forschungszentrum Geobiologie, Arbeitsgruppe "Evolution der Metazoen", Georg-August-Universität Göttingen

Prof. Dr. Jouko Rikkinen, Department of Biosciences, University of Helsinki, Finland

Prof. Dr. Volker Thiel, Geowissenschaftliches Zentrum, Abteilung Geobiologie, GeorgAugust-Universität Göttingen

Tag der mündlichen Prüfung: 16.05.2013 


\section{Versicherung}

Hiermit versichere ich an Eides statt, dass die Dissertation mit dem Titel „The evolution of the Ascomycota - new insights from Mesozoic and Cenozoic amber fossils“" selbstständig und ohne unerlaubte Hilfe angefertigt wurde.

Göttingen, den 14.04.2013

Unterschrift:

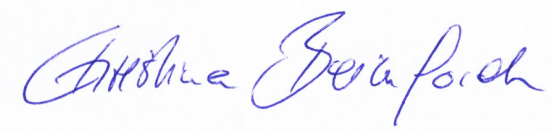




\section{Contents}

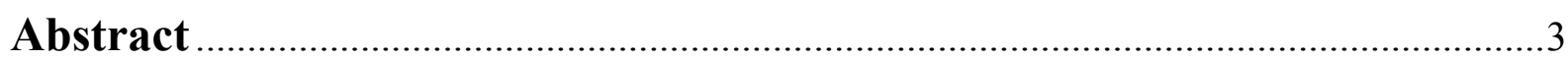

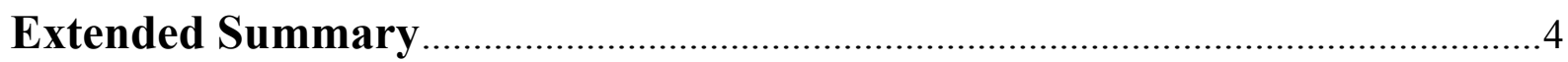

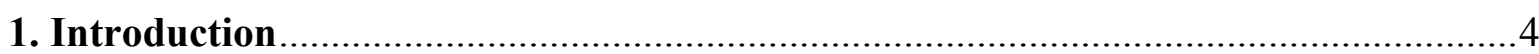

1.1 What are fungi? - Some facts of delimitation.........................................................

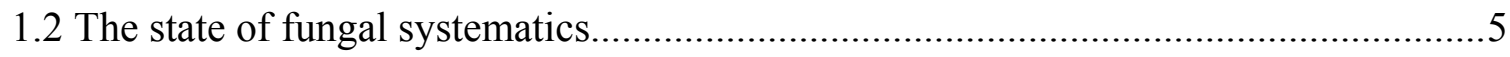

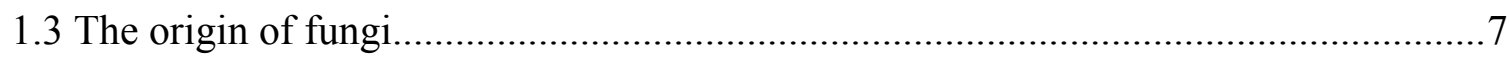

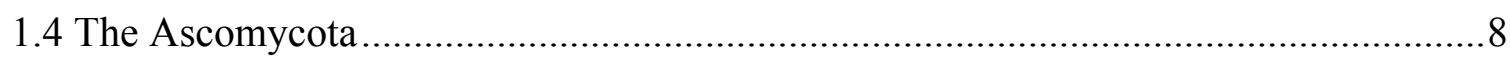

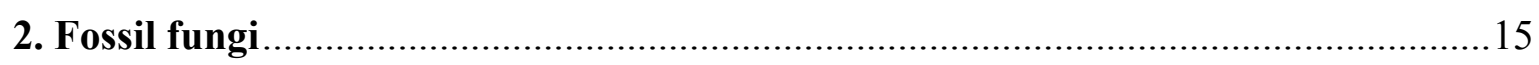

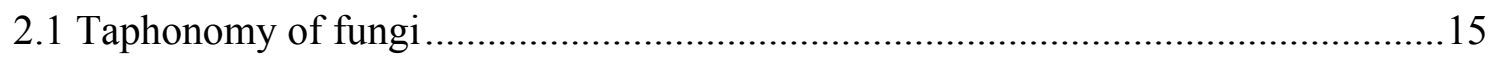

2.2 Fossil ascomycetes from amber and chert......................................................... 17

3. Contributions to the systematics, taphonomy and

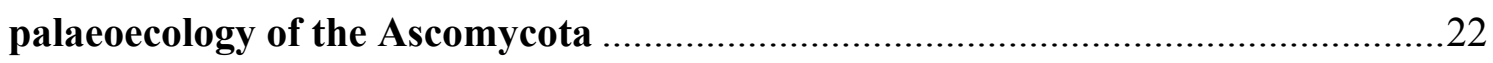

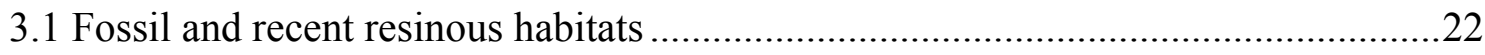

3.2 A resinicolous species of Chaenothecopis with proliferating

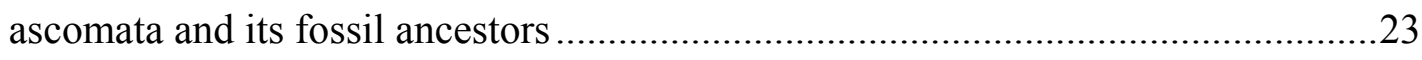

3.3 A fossil and a recent representative of the anamorphic genus

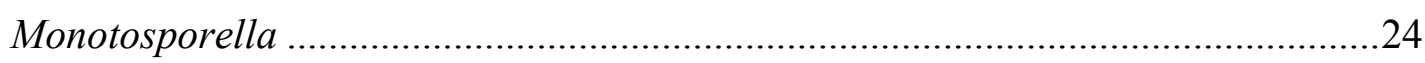

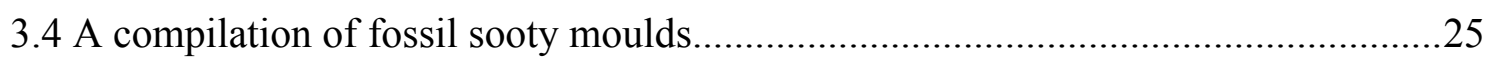

3.5 The first fossil ectomycorrhizae associated with an angiosperm .............................26

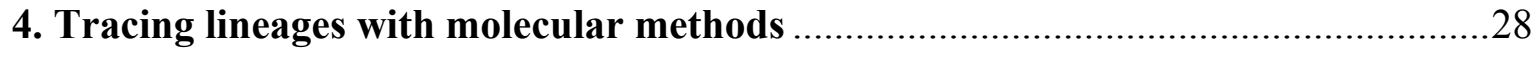

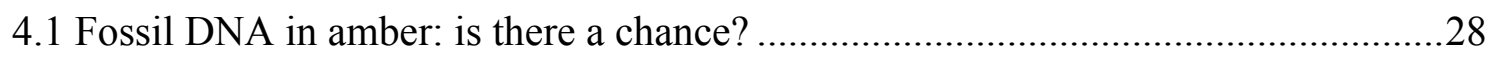

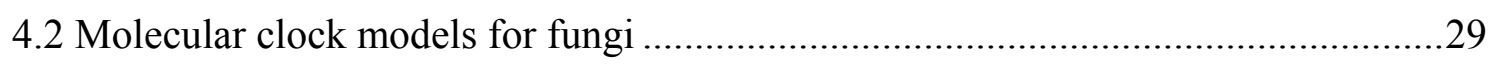

4.3 Using fossil ascomycetes from amber and chert to estimate the

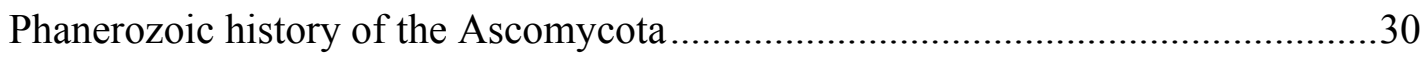

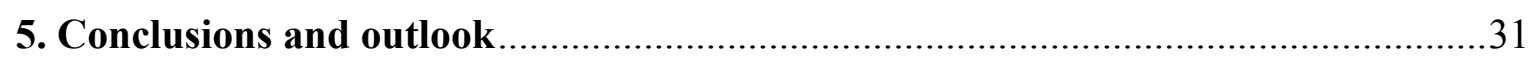

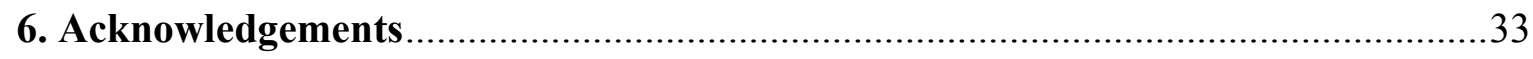

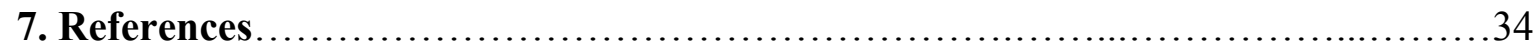

Appendices................................................................49

Curriculum Vitae........................................................... 199 


\section{Appendices}

[1] Beimforde C, Schmidt AR (2011) Microbes in resinous habitats: a compilation from modern and fossil resins. In: Reitner J, Queric N-V, Arp G (eds) Advances in Stromatlite Geobiology. Lecture Notes in Earth Sciences. 131, 391-407.

[2] Tuovila H, Schmidt AR, Beimforde C, Dörfelt H, Grabenhorst H, Rikkinen J (2013) Stuck in time - a new Chaenothecopsis species with proliferating ascomata from Cunninghamia resin and its fossil ancestors in European amber. Fungal Diversity 58, 199-213.

[3] Sadowski E-M, Beimforde C, Gube M, Rikkinen J, Singh H, Seyfullah LJ, Heinrichs J, Nascimbene PC, Reitner J, Schmidt AR (2012) The anamorphic genus Monotosporella (Ascomycota) from Eocene amber and from modern Agathis resin. Fungal Biology 116, 1099-1110.

[4] Schmidt AR, Beimforde C, Seyfullah LJ, Wege SE, Dörfelt H, Girard V, Grabenhorst H, Gube M, Heinrichs J, Nel A, Nel P, Perrichot V, Reitner J, Rikkinen J (in review). Amber fossils of sooty moulds. Review of Palaeobotany and Palynology.

[5] Beimforde C, Schäfer N, Dörfelt H, Nascimbene PC, Singh H, Heinrichs J, Reitner J, Rana RS, Schmidt AR (2011) Ectomycorrhizas from a Lower Eocene angiosperm forest. New Phytologist 192, 988-996.

[6] Beimforde C, Feldberg K, Nylinder S, Rikkinen J, Tuovila H, Dörfelt H, Gube M, Jackson D, Reitner J, Seyfullah LJ, Schmidt AR (submitted). Estimating the Phanerozoic history of the Ascomycota lineages: combining fossil and molecular data. Molecular Phylogenetics and Evolution. 


\begin{abstract}
This thesis contributes to the knowledge of the evolutionary history and palaeoecology of the Ascomycota (sac fungi). The six included papers are based on the investigation of Cretaceous and Palaeogene amber inclusions and deal with systematics, taphonomy and palaeoecology of newly discovered ascomycetes. Two new fossil ascomycetes of the resinicolous genus Chaenothecopsis (Mycocaliciales, Eurotiomycetes) are described from Eocene Baltic and Oligocene Bitterfeld ambers and are compared to a new modern representative, described as Chaenothecopsis proliferatus. Besides, the anamorphic fungal genus Monotosporella (Ascomycota, Sordariomycetes) has been recovered from a piece of Early Eocene Indian amber, as well as from the surface of extant resin flows in New Caledonia. The newly described fossil Monotosporella doerfeltii represents the second fossil record of Sordariomycetes, as well as the first fossil of its particular order (either Savoryellales or Chaetosphaeriales). Furthermore, an overview about the fossil record of capnodialean sooty moulds fungi is provided. This traces the fossil record of this group of fungi from the Early Miocene back to the Early Cretaceous. Another study presents the first known fossil ectomycorrhizae from an angiosperm forest. The fossil ascomycete mycobiont is associated to an angiosperm of the family Dipterocarpaceae and is described as Eomelanomyces cenococcoides. Apart from previously described fossil ascomycetes, the new described fossils were used to constrain a molecular clock in order to estimate the origin and divergence of Ascomycota lineages with a Bayesian approach (BEAST). This is the first study to combine molecular and fossil data solely from within the Ascomycota in order to produce a chronogram with multiple calibration points throughout the Phanerozoic. According to our results the diversification of the ascomycetes started in the Cambrian, followed by a continuous diversification throughout the Phanerozoic that was likely unaffected by mass extinctions. This suggests that the ecological diversity within each lineages ensured that at least some taxa of each group were able to survive global crises and rapidly recovered.
\end{abstract}




\section{Extended Summary}

\section{Introduction}

\subsection{What are fungi? - Some facts of delimitation}

With an estimated number of 1.5 million species (Hawksworth, 1991; 2001) the fungi constitute one of the major eukaryotic groups on earth. Members of this group exhibit a tremendous variety of lifestyles and morphologies ranging from microscopic single celled organisms/individuals to huge multi-cellular colonies with species that are known to be among the largest and oldest organisms on earth (Brazee et al., 2012). There is virtually no aquatic or terrestrial ecosystem which is not occupied by a diverse range of fungal species. Fungi are important degraders, particularly for persistent organic matter such as lignin, and play a significant role in nutrient cycles of present ecosystems. Many fungal species live in symbiotic association, from which some such as mycorrhizae or lichens, are extremely successful (Heckmann et al., 2001; Brundrett, 2002; Beimforde et al., 2011). In particular mycorrhizae, associations between fungi and vascular plant roots, are abundant and ubiquitous in terrestrial ecosystems (Beimforde et al., $2011 \mathbf{[ 5}^{\mathbf{1}}$ ). This symbiosis is considered to be a key innovation that enabled early land plants to extensively colonize terrestrial habitats (e.g. Cairney, 2000).

Fungi neither belong to the kingdom Viridiplantae nor to the Metazoan kingdom. Unlike most plants, they exhibit a heterotrophic life style and do not contain any chloroplasts or amyloplasts. In contrast to most animals, fungi are sessile and exhibit external ingestion, which is followed by the absorption of nutrients. Exceptions to this are representatives of the Chytridiomycetes, which produce self-mobile flagellated zoospores. Like Chytrydiomycetes, most species that were formerly grouped in the Oomycota, produce flagellated zoospores. These species are now treated as protists (eukaryotes with a unicellular level of organisation, without cell differentiation into tissues) and are as assigned to Peronosporomycetes in the Stramenopiles (Adl et al., 2005). Thus they even belong to another super group of the Eukaryota and are more closely related to brown algae (Phaeophyceae) than to fungi (Adl et al., 2005).

However, it is an ongoing debate about how to define the fungi and whether particular groups should be included or excluded from the fungal kingdom. So far, no general definition exists but, next to phylogenetic classifications, a range (or combination) of features delimit fungi from other organisms. The most characteristic features are their cell walls that contain chitin. Fungi are never autotrophic and never

\footnotetext{
${ }^{1}$ References to papers included in this thesis are indicated by bold numbers in brackets after the year of publication which refers to the respective appendix.
} 
contain any plastids. Their unique biosynthetic lysine-pathway, the permeability between their cells (hyphae) through septae, their sexual (teleomorphic) or/and asexual (anamorphic) life cycles and their unique form of tubulin (involved in nuclear division) are some further distinctive characteristics of fungi.

\subsection{The state of fungal systematics}

Due to their primarily sessile mode of life, early classifications (e.g. Copeland, 1938; 1956) grouped the fungi together with plants. This is the reason why the field of Mycology is still strongly linked to that of Botany. The idea of fungi belonging to a separate kingdom was established/or introduced in 1949 by Jahn and Jahn (1949) and was advanced by Whittaker (1959). Later on, in the early 1990s molecular methods were established and Woese (1987) introduced the three domain system, including Bacteria, Archea and Eukaryotes.

Molecular methods have revolutionized the field of taxonomy during the last two decades. Compared to morphological approaches these methods provide many more characters for species delimitation, by comparing sequences of homologous genes encoding for conserved biological functions or even whole genomes (for fungi e.g Fitzpatrick et al., 2006). Nevertheless, molecular approaches are also limited since potential sources of errors such as undetected (e.g. homoplasy, Goloboff et al., 2008) or wrongly inferred substitutions (e.g. long branch attraction, Bergsten 2005, 1978), polymorphisms and gene specific evolution have to be taken into account. Since most species are not sequenced and/or even discovered so far (Blackwell, 2011) taxon sampling biases have to be considered too (e.g. Cusimano et al., 2012). The field of phylogenetics is highly dynamic and many new approaches such as parallel pyrosequencing which is referred to as next generations-sequencing (Voelkerding et al., 2005) and resulting pyhylogenomic studies (Delusc, 2005) will further improve resulting phylogenies. Nevertheless, some sources of error such as non-phylogenetic signals still exists (Philippe et al., 2011) and the increased quantity of data in phylogenomic studies does not necessarily result in more reliable phylogenies if the quality of the used data is poor (Jeffroy et al., 2006). However, in any case traditional diagnostic features such as morphological and physiological aspects should not be disregarded in current classification systems as they serve to provide additional information. Nowadays, classifications are often based on variations in homologous genes but involve microscopic, ultrastructural and biochemical characters too (e.g. Hibbett et al., 2007).

Many recent studies have shed light on fungal taxonomy. As the studies of individual groups of fungi are so numerous, only an overview of some important projects is given here. The 'Dictionary of fungi' (Kirk et al., 2008) and the broad work 
'The Mycota' (McLaughlin et al., 2001a; 2001b) for instance contain a comprehensive classification up to genus level. In the project 'Assembling the Fungal Tree of Life' (AFTOL, Lutzoni et al., 2004) many mycologist collaborated in order to establish a phylogenetic hypothesis containing all major clades of fungi and achieve the aim of a public database containing sequence data, ultrastructural and biochemical characters (Celio et al., 2006). James et al. (2006) shed new light on early-diverging clades of fungi and discussed four independent losses of the flagellum in the kingdom fungi by constructing a phylogenetic hypothesis based on six genes and over 200 species. Another important work is the 'Deep Hypha' project, which is published in issue 98 (2006) of Mycologia. Other crucial multigene projects focus on individual groups of fungi (e.g. Miadlikowska et al., 2006; Hibbett et al., 2007, Schoch et al., 2009; Matheny et al., 2007; Ebersberger et al., 2012; Kumar et al., 2012; Morgenstern et al., 2012). Additionally, in the last few years many online resources were established which facilitate the exchange and distribution of new data and information throughout the mycological community. Examples are a classification of Ascomycota (www.fieldmuseum.org/myconet), the coordination of a global fungal nomenclature in Index Fungorum (www.indexfungorum.org), the documentation of new mycological nomenclature and associated data such as descriptions and illustrations in MycoBank (www.mycobank.org), and the general source of sequence data, related publication and numerous tools on GenBank (www.ncbi.nlm.nih.gov). All these novelties of the last two decades have lead to considerable opportunities in the fungal systematics. In their study 'A higher-level phylogenetic classification of the fungi' Hibbett et al. (2007) collaborated with numerous other mycologists and proposed a phylogenetic classification of the kingdom fungi, which reflects the current knowledge of phylogenetic relationships (Fig.1). The major changes in comparison to previous classifications are related to groups that traditionally belong to the Chytridiomycota and Zygomycota. In the newly proposed system, the phylum Chytridiomycota is retained but the Blastocladiomycota and the Neocallimastigomycota represent separate phyla of flagellated fungi. The taxa that were traditionally placed in the Zygomycota are now distributed among the Glomeromycota and several subphyla. The Ascomycota and Basidiomycota were assigned to the subkingdom Dikarya. As a result, six phyla are proposed: Blastocladiomycota, Neocallimastigomycota, Chytridiomycota, Glomeromycota, Basidiomycota and Ascomycota. Furthermore, four subphyla (Mircosporidia, Kickxellomycotina, Zoophagomcotina and Entomophtoromycotina) are placed in the category fungi incertae sedis. 


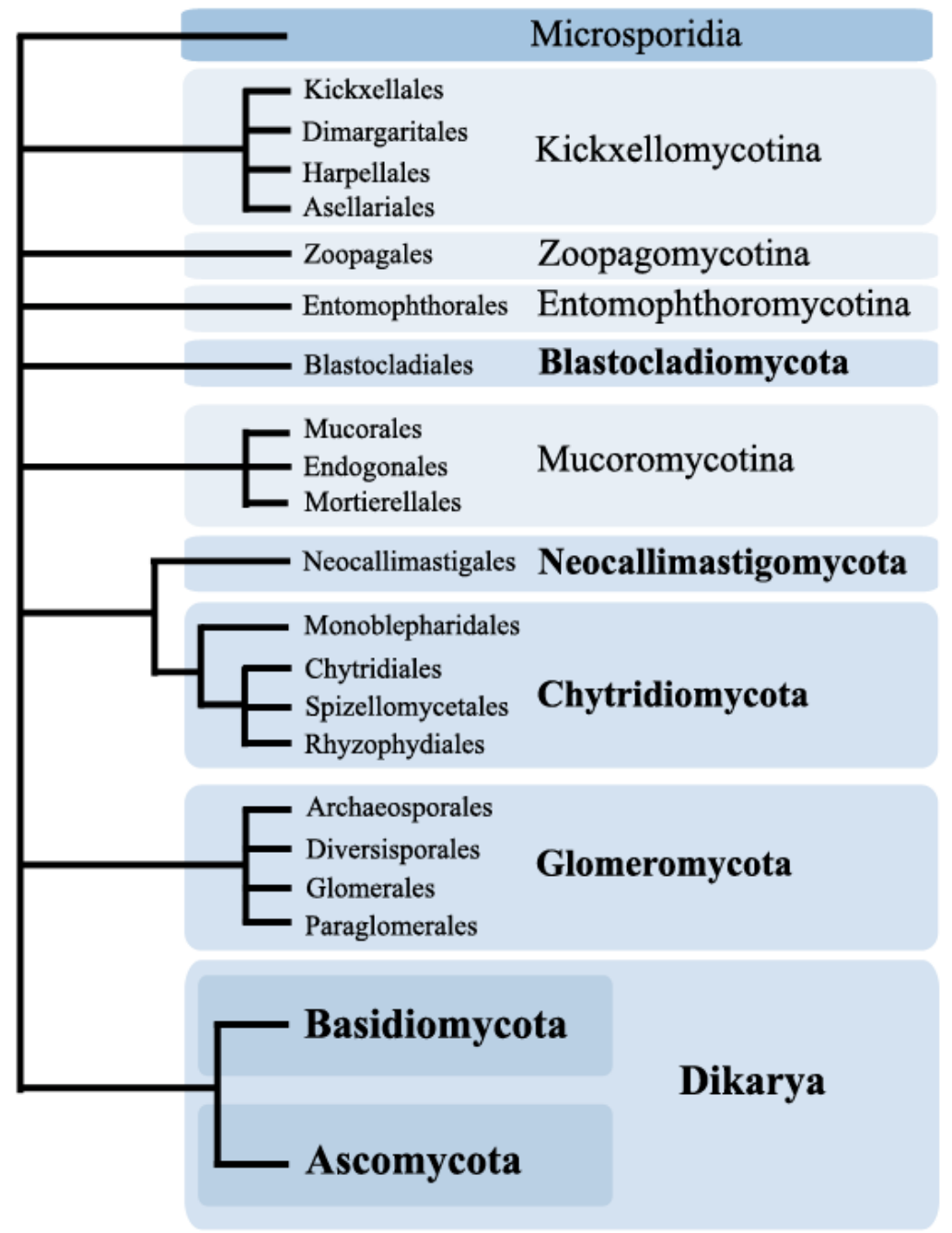

Figure 1. Phylogeny and classification of Fungi modified after Hibbett et al. (2007). Branch lengths are not proportional to genetic distances.

\subsection{The origin of fungi}

Several lines of evidence indicate that the fungi are a very ancient group of organisms that has diverged at a basal stage of the Eukaryota. Although several kingdoms such as animals, plants, fungi, and ciliates appear monophyletic, it is challenging to decipher the relationships between those kingdoms and various other groups of unicellular protists (e.g. Koonin, 2010). Within the eukaryotic supergroups, the fungi are placed in the Opisthokonta, making them much more closely related to the Metazoan kingdom than to Viridiplantae (e.g. Baldauf et al., 2000; Bapteste et al., 2001; Lang et al., 2002). The relationships within the Opisthokonta are not yet resolved and the closest phylogenetic relative of the fungi is still controversial. Based on ribosomal information, several current studies propose a sister relationship between fungi and the nucleariids, an assemblage of amoeboid protists from aquatic environments (Liu et al., 2009; Lara et al., 2010). It seems that the amoeboid protist of Nuclearia, a phagotropic member of the 
nucleariids growing on bacteria and algae, is the closest relative to the fungal kingdom (Steenkamp et al., 2006). Another putative sister group could be a member of the endoparasitic genus Rozella. With the exception of Rozella coleochaetis (Sparrow et al., 1965) that infects an alga, representatives of this genus parasitize other zoosporic fungi, mainly Chytridiomycetes and species formerly as assigned to Oomycetes (Held, 1981). Subsequent studies suggested that the genus Rozella might be the earliest branch within the fungal kingdom (Lara et al., 2010). Unlike fungi, members of this group possess phagocytosis in their trophic stage, which contradicts the definition of fungi and Jones et al. (2011a) further argued that Rozella is lacking chitin in their cells and should not be defined as fungi. In contrast, James and Berbee (2011) pointed out that Rozella possess a fungal-specific chitin synthase and chitin in walls of resting sporangia. Nevertheless, most current studies suggest not defining Rozella as a fungus but as very close sister group (e. g. Jones et al., 2011b; 2011). The latter authors placed Rozella into a newly defined and highly diverse group, the so called Cryptomycota, formerly described as Rozellida (Lara et al., 2010). However, if not Rozella, the enigmatic Microsporidia, intracellular parasites that parasitize many other eukaryotes, seems to form the earliest diverging branch of the fungal phylogenetic tree (James et al., 2006). Microsporidia are now placed in the fungal kingdom (Hibbett et al., 2007) but the phylogenetic position is still controversial, since a sister relationship of the Microsporidia to the Entomophthorales, the Blastocladialeanchytrids, the zygomycete Dimargaris or to the Dikarya also seems possible (James et al., 2006).

Fungi are likely to be derived from an aquatic environment. The Chytridiomycota are a paraphyletic assemblage and, next to Microsporidia, seem to constitute the most basal fungal group. Many recent chytridiomycetes and also members of the above discussed genera Nuclearia and Rozella share an aquatic mode of life.

\subsection{The Ascomycota}

The phylum Ascomycota comprises 15 classes and 68 orders and is by far the largest and most diverse group of the fungal kingdom. Around 64,000 species of approximately 6400 genera are described so far (Kirk et al., 2008) and the real number is likely to be much higher (Hawksworth, 1991; 2001).

Appearing a little inconspicuous on the first view, members of the Ascomycota actually play a significant role for earth's ecosystems and diverse aspects of human life. Besides comprising unpleasant pathogens, many species are integrated in beneficial industrial and agricultural settings and, even more important provide a variety of medical substances. Members of the genus Penicillium (Eurotiales) for instance are known for their production of antibiotics and are irreplaceable with respect to human health care. The aggressive mode of life of some saprophytes like Aspergillus species 
goes along with the production of diverse enzymes that degrade a wide variety of complex molecules and can be utilized for a plenty of industrial processes (Pitt, 1994). Apart from that, ascomycetes ${ }^{2}$ take a significant part in present nutrient cycles on earth.

Members of the Ascomycota are ubiquitous in aquatic and terrestrial ecosystems and occur in numerous ecological habitats. They can live saprotrophically, necrotrophically and biotrophically as symbionts (mycobionts) with diverse organisms or as parasites in or on plants, animals and humans (Webster and Weber, 2009). Like many other fungi, members of the Ascomycota can exist in very exceptional environments such as solid rocks (Sterflinger et al., 1999; Beimforde, 2011) or under hypersaline conditions (KisPapo et al., 2003). Some species can adapt their mode of life or morphology to changing ambient conditions. Many types of yeasts for instance are dimorphic and can switch from yeast to filamentous states or vice versa (Webster and Weber, 2009). Furthermore, numerous ascomycetes form lichens if a potential phytobiont is available, but live as saprophytes in their absence (Wedin et al., 2004). In fact, lichens cover a huge area of the surface on earth and more than two fifths of all ascomycetes live in a lichenized association (Grube and Winka, 2002). A special feature of ascomycetes (and basidiomycetes) concerns their life-cycles that can involve anamorphic (vegetative) and teleomorphic (sexual) modes of reproduction. Both forms can prove to succeed in given environmental conditions and may evolve independently over the course of time. In fact, a huge variety of ascomycete (and basidiomycete) species are only known from their anamorphic state (and vice versa). Species that are only known from their anamorphic state and were formerly placed into the phylum Deuteromycota the so called 'Fungi Imperfecti'.

What distinguishes the Ascomycota from other fungi is a sac-like structure, the ascus, in which they produce their sexual spores. The ascus consists of a rigid cell wall and typically contains eight haploid ascospores. For most members of the Ascomycota the ascus resides in a defined fruiting body, called ascoma (or ascocarp) which can have various shapes (cleistothecial, apothecial, perithecial or ascolocular, see Webster and Weber, 2009). Exceptions are basal members of the Ascomycota such as the Saccharomycotina and Taphrinomycotina which do not develop defined ascomata but have naked asci. The development of the ascoma, especially the structure of asci and the mechanisms of spore release are the most important synapomorphies to denfine groups within the Ascomycota. There are three different mechanisms of how asci release their spores: prototunicate, unitunicate, and bitunicate (Webster and Weber, 2009). Prototunicate asci have a thin, delicate wall and exhibit a passive form of spore release

\footnotetext{
${ }^{2}$ The term ascomycetes is a synonym for members of the subphylum Pezizomycota comprising Ascomycota species that produce asci inside fruiting bodies instead of naked asci (Hibbett et al., 2007).
} 
such as dissolving the wall layer. Unitunicate and bitunicate asci actively eject their spores by discharge through the ascus tip that can have a lid-like structure (operculum) or lack it (inoperculate). The walls of unitunicate and bitunicate asci have two layers. In contrast to unitunicate asci in which both layers are attached to each other, the layers of bitunicate asci separate from each during dehiscence. Dothideomycetes possess a special form of bitunicate asci, termed fissitunicate asci, in which both layers are completely separated. Many variations of spore release mechanisms exist, but usually they are related to the types of ascomata. Apothecia are typically disk-shaped to cupshaped and produce operculate or inoperculate unitunicate asci in a well defined layer (hymenium) which is exposed to the environment. Perithecial ascomata are partially closed and the ascus production occurs within the central cavity of the ascoma (Spartafora et al., 2006). The asci of perithecial ascomata are usually unitunicate and lack a lid-like structure (inoperculate). Cleistothecial ascomata are completely closed and contain prototunicate asci. Their wall typically dissolves at maturity. Ascolocular asomata are characterized by thick-walled asci in preformed openings in the stromatic tissue. Their wall layers separate in a fissitunicate manner which is often called a“jackin-the-box" manner. The mentioned types of asci and ascomata describe only generalized types but additional variants of fruiting bodies and types of asci exist.

Although there is a broad range of diagnostic structures, the vast number of species makes it challenging to classify the phylum Ascomycota. However, due to continuous advances of molecular approaches great progress has been made in elucidating deeper phylogenetic relationships of this phylum (e.g. Lutzioni et al., 2004; Miadlikowska et al., 2006; Schoch et al., 2009). Nevertheless, many families and genera could still not be assigned with confidence to any family or higher phylogenetic level (Kirk et al., 2008). Due to the numerous species of the Ascomycota and difficulty of excluding potential homoplasy of morphological traits, former classification systems that were mainly based on morphological and on ecological traits are controversial. Those previous systems primarily utilized the type of fruiting bodies and ascus arrangements and delimit for instance Hemiascomycetes (yeasts), Plectomycetes (groups that form mainly cleistothecia), Pyrenomycetes (groups that form mainly perithecia), Discomycetes (groups that form mainly apothecia) and Loculoascomycetes (groups that form ascolocular ascomata). Further former terms include Archiascomycetes (which include the basal groups Taphrinomycetes, Schizosaccharomycetes and Pneumocystis), Euascomycota (which is another term for higher fungi and describes all fungi with defined fruiting bodies) and Hymenoascomycetes or Ascohymeniales (which include operculate and inoperculate discoycetes and pyrenomycetes). Those terms will be avoided in this thesis. Instead, the terms used in this thesis are based on recent classifications presented by Hibbett et al. (2007). In several cases the morphological data confirm sequence data, but many others have been rearranged in the last few years. 
Currently, based on various studies (e.g. Lutzioni et al., 2004; Blackwell et al., 2006; Miadlikowska et al., 2006; Hibbett et al., 2007; Schoch et al., 2009), three subphyla are accepted: (1) Taphrinomycotina (former Archiascomycetes), (2) Saccharomycotina (former Hemiascomycetes) and (3) Pezizomycotina (species that develop defined fruiting bodies). The relationships between some Pezizomycotina classes, mainly concerning classes comprising the super class Leotiomyceta (Schoch et al., 2009) are still unresolved. Fig. 2 represents a Bayesian phylogenetic hypothesis of the Ascomycota based on ribosomal (SSU, LSU) and protein coding (RPB1, RPB2). The following sections give a short overview of morphological and ecological traits as well as progressive relationships within the Ascomycota. More detailed aspects and relationships of individual groups can be found in the related publications cited herein.

The Taphrinomycotina consist of four classes (Schizosaccharomycetes, Taphrinomycetes, Neolectomycetes and Pneumocystidomycetes) and comprise species that mainly live as parasites in or on plants, animals and humans. Some members may cause serious diseases. Pneumocystis for instance infects mammalian lungs and cause Pneumocystis pneumonia (PCP) in humans. This subphylum represents the most basal group of the Ascomycota. With the exception of Neolecta, constituting the sole genus of the Neolectomycetes, all members of the Taphrinomycotina lack defined ascomata but produce naked asci. They have been seen as a paraphyletic assemblage (Sugiyama et al., 2006), but recent molecular studies rather suggest monophyletic affiliations (e. g. Spatafora et al., 2006; Wang et al., 2009).

The sole order Saccharomycetales of the subphylum Saccharomycotina is divided into 11 families. Like the Taphrinomycotina, members of the Saccharomycotina build naked, free asci either directly following karyogamy or sometimes after a diploid phase (Webster and Weber, 2009. The subphylum Saccharomycotina is supposed to represent the sister group to all higher fungi (Pezizomycotina/ascomycetes) that develop ascomata. The term "true yeast" is a common expression for members of the Saccharomycotina. What delimits the "true yeasts" from the Schizosaccharomycetes is that they reproduce by budding rather than by fission. Several studies propose an early divergence of Saccharomycotina from Schizosaccharomycetes and confirm a close relationship between the Pezizomycotina and Saccharomycotina (e. g. Wang et al., 2009).

The Pezizomycotina (ascomycetes) is the largest subphylum of the Ascomycota and contains the majority of filamentous members that develop ascomata. Ten classes are defined within this subphylum: Pezizomycetes, Orbiliomycetes, Dothideomycetes, Arthoniomycetes, Eurotiomycetes, Laboulbeniomycetes, Lichinomycetes, Lecanoromycetes, Leotiomycetes and Sordariomycetes. 


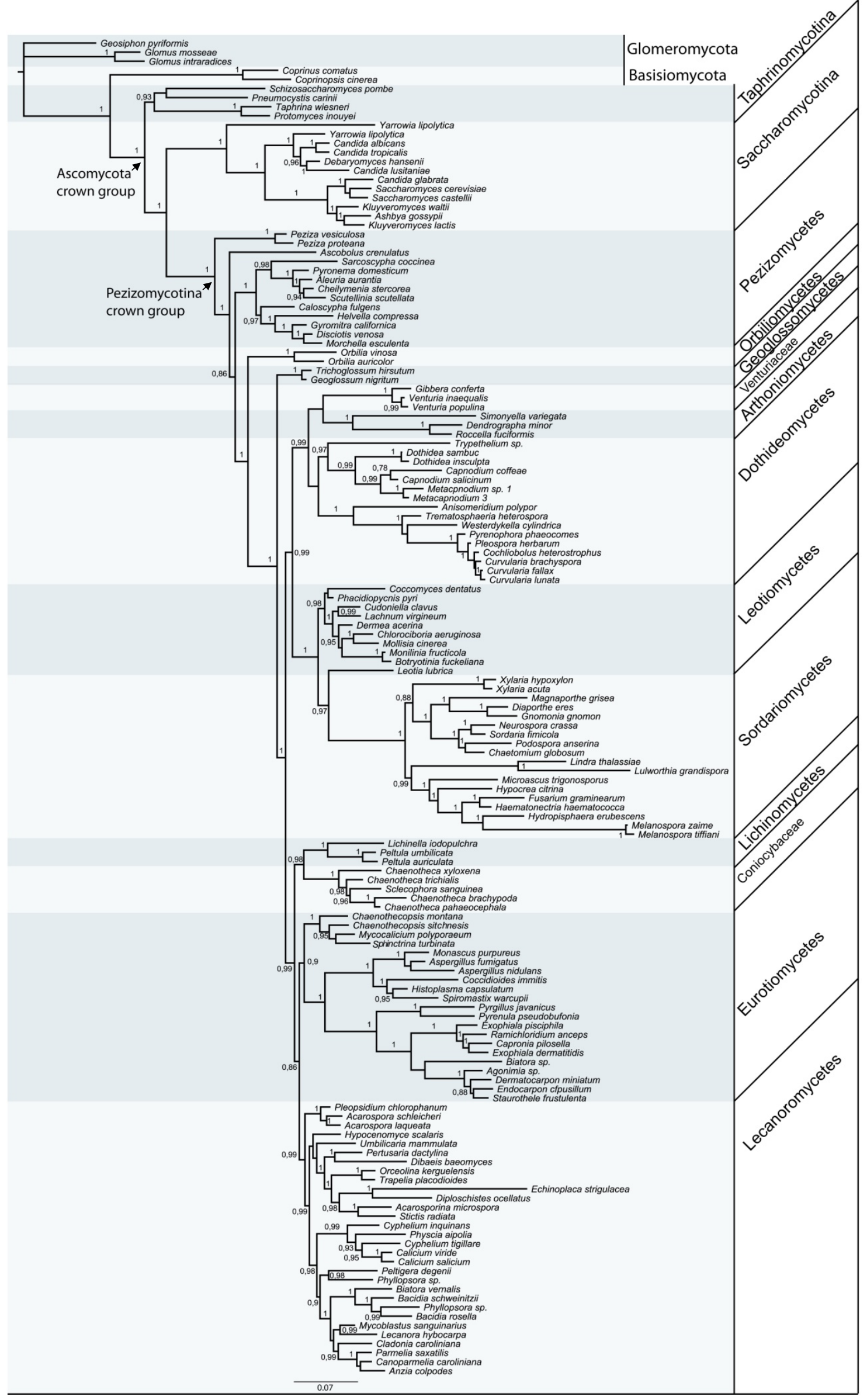


Figure 2. The 50\% majority Rule consensus phylogram achieved in this study from nuclear ribosomal (SSU and LSU) and protein coding data (RPB1 and RPB2) of 142 Ascomycota species by using MrBayes 3.1.2 (Ronquist and Huelsenbeck, 2003) under GTR $+\mathrm{I}+\mathrm{G}$ model obtained from jmodeltest (Posada, 2008) for two separate partitions (ribosomal and protein coding genes). Two independent runs, with four chains, were conducted simultaneously for 20 million generations with trees sampled every $1000^{\text {th }}$ generation. $25 \%$ percent of the sampled trees were discarded as burn in. Numbers above branches indicate Bayesian posterior probabilities (BBP).

Most members of the Pezizomycetes and Orbiliomycetes build apothecial ascomata (e.g. Spatafora et al., 2006). The Pezizomycetes are considered to represent the sister group to all other members of the Pezizomycotina. In contrast to Orbiliomycetes which form inoperculate asci, members of the Pezizomycetes exhibit operculate asci. Obiliomycetes include saprophytic species and predatory species involving different types of trapping devices (Yang et al., 2007).

Dothideomycetes were formally defined as Loculoascomycetes (Luttrell, 1955). In contrast to the ascohymenial development that is found in the majority of other Pezizomycotina classes, their asci develop in locules (ascolocular) which are preformed within vegetative hyphae. Members of this group live as pathogens in plants, animals or fungi, occur as endo- or epiphyts on plants but also as saprophytes degrading carbohydrates from plant matter or dung. Dothideomycetes form bitunicate ascus cells which consist of a thick extensible inner layer (endotunica) and a thin inextensible outer layer (ectotunica). There are numerous variations of spore release mechanisms in this group, but most species have fissitunicate asci, ejecting the spores by the extension of the inner ascus wall and ripping of the outer wall (Schoch et al., 2006). Schoch et al. (2006) established a phylogenetic hypothesis of relationships within the Dothideomycetes based on four nuclear loci.

Arthoniomycetes develop apothecia with bitunicate asci. They live as saprophytes on plants or are associated with algae to form lichens. They occur mostly in tropical and subtropical latitudes. Although there are clear morphological differences between Arthoniomycetes and Dothideomycetes, such as the ascohymenial ascoma development in contrast to asolocular ascoma (Henssen and Thor, 1994), a close relationship between the Dothideomycetes and Arthoniomycetes was reported and confirmed in this thesis, Fig. 2. (Lutzoni et al., 2004; Schoch et al., 2006).

Eurotiomycetes live as saprophytes, parasites or lichens. They were formerly described as Plectomycetes mainly producing closed asomata (cleistothecia) with prototunicate asci. However, nowadays two major subclasses are defined, the Eurotiomycetidae (cleistothecia with prototunicate asci) and the Chaetothyriomycetidae (perithecia with bitunicate asci, Geiser et al., 2006). It has been suggested that the Eurotiomycetes evolved by the loss of the bitunicate ascus and the conjugated mode of 
forcible spore discharge (Berbee, 1996). The Eurotiomycetidae include many species such as Aspergillus and Penicillium (Eurotiales) that are of great interest concerning industrial and medical issues (Pitt, 1994).

Laboulbeniomycetes are widespread parasites on insects, mites and millipedes (Arndt et al., 2003). They develop perithecial ascoma with prototunicate asci. Two orders are defined in the Laboulbeniomycetes, the Laboulbeniales and the Pyxidiophorales (Hibbett et al., 2007). Their placement in the Ascomycota has long been controversial, and they were either treated as an order, Laboulbeniales (Hawksworth et al., 1995) or as a class Laboulbeniomycetes (Barr, 1983). Weir and Blackwell (2001) have proposed to handle this group as a separate class of Ascomycota, along with Schoch et al. (2009) who were the first to place this insect symbiont class with bootstrap support as a sister group to Sordariomycetes.

Lecanoromycetes comprise the largest class of the Ascomycota containing most of the lichen-forming species. Its members exhibit a huge variety of phenotypic natures (Miadlikowska et al., 2006). The Lecanoromycetes are divided in to three subclasses (Acarosporomycetidae, Ostropomycetidae and Lecanoromycetidae) and in to ten orders. The monophyly of the subclasses Acarosporomycetidae and Ostropomycetidae could be confirmed, whereas the relationships of the Lecanoromycetidae (the largest subclass) are still controversial (Miadlikowska et al., 2006). Members of the Lecanoromycetes mainly possess apothecia but they can also develop perithecial ascomata. Different mechanisms of spore release appear in this class, with asci having bitunicate, inoperculate or prototunicate types. Their lichinized associations involve a broad range of algae and cyanobacteria as phytobionts (Cordeiro et al., 2005). There have been numerous studies in the last years that focused on individual groups of the Lecanoromycetes (parmeloid lichens: Crespo et al., 2007; Arup et al., 2007). Due to a conspicuous host specify of some phytobionts they have been suggested as useful for classification of some groups (Rambold et al., 1998). Furthermore, many Lecanoromycetes produce a variety of unique secondary compounds that are used in recent classifications (e.g. Schmitt and Lumbsch, 2004).

Representatives of the Leotiomycetes produce apothecia with unitunicate inoperculate asci or cleistothecia having prototunicate asci. They comprise five orders and 19 families (Kirk et al., 2008). Representatives, especially the Helotiales as largest non-lichenized group of ascomycetes, display various life styles and live biotropically as plant pathogens, endophytes, nematode-trapping fungi, mycorrhizae, fungal parasites, but also as saprobes in aquatic and terrestrial niches (Wang et al., 2006). Furthermore the class exhibits a high morphological variability that is noticeable, for instance, in very different appearances of the apothecia. Wang et al. (2006b) proposed ecological characters of some groups of Leotiomycetes as potentially useful diagnostic traits. They mention the orders Erysiphales, Cyttariales, Thelebolales and Rhytismatales as showing 
distinct ecological characters and nutritional modes that are, together with morphology characteristics, unique for each group. Phylogenetic analysis of this class of ascomycetes have just started and, according to Wang et al. (2006), the current taxon and character sampling needs to be enhanced to stabilize internal nodes of the class.

The Lichinomycetes contain lichen- forming species assembled in two orders (Lichinales, Eremithallales). They form apothecia containing bitunicate, inoperculate or prototunicate asci (Spatafora et al., 2006). Based on protein coding and ribosomal data Reeb et al. (2004) delimited representatives from Lecanoromycetes and described it as new class. All species of Lichinales build symbiotic associations with Cyanobacteria whereas species of the Eremithallales are associated with algal cells (Trentepohlia). Lücking et al. (2008) introduced the order Eremithallales and described the distinct mode of lichen forming. Instead of building a thallus that encloses the phytobiont the algal cells are located in periderm cells of the tree bark. Pierto (2008) found that polysaccharide of Lichinomycetes differ from those of Lecanoromycetes and suggested that an ancestor of the Lichinomycetes containing this form of polysaccharide was probably part of an early radiation in the ascomycetes.

Most Sordariomycetes build perithecia with inoperculate unitunicate asci but cleistothecial ascomata are also produced (Zhang et al., 2006). According to Eriksson (2006) the Sordariomycetes contain 16 orders in three subclasses, constituting the largest non-lichinized group of ascomycetes. Many Sordariomycetes live biotrophically, often as endogeneous parasites in plants, humans or animals. Others are saprobes occupying mainly terrestrial habitats. Species from various groups live in aquatic habitats which is considered a derived character that probably evolved several times (Samuels and Blackwell, 2001). It is likely that Sordariomycetes and Leotiomycetes share a common ancestor. This close relationship was supported by bayesian and maximum likelihood analysis (Spatafora et al., 2006; Lumbsch et al., 2005).

\section{Fossil fungi}

\subsection{Taphonomy of fungi}

In comparison with organisms that have robust and strong tissues, there is only a rare fossil record of soft bodied organisms such as representatives of the fungal kingdom. Fungal hyphae and fruiting bodies are delicate and soft, which makes them easily degradable. Generally, the most exceptional preservation of organisms in sedimentary rocks occurs in fine-grained carbonates of lacustrine and shallow marine settings (e.g. Frickhinger, 1994; Martínez-Delclós et al., 2004). Those conditions may be suitable for the preservation of labile soft-tissues, but are still insufficient to preserve very delicate 
features of microbial organisms such as fungi. In contrast, amber and chert preserve those organisms in a greater detail and regardless of their susceptibly to decay. Stankiewicz et al. (1998) posed the question why fossils embedded in amber remain in such morphologically pristine condition and found that the volatile components of the resin have penetrated even the internal tissues, resulting in an extraordinary, threedimensional preservation. The diagenesis of enclosed organisms is not yet clear and depends on various factors such as the type of resin and the tissue of the inclusion.

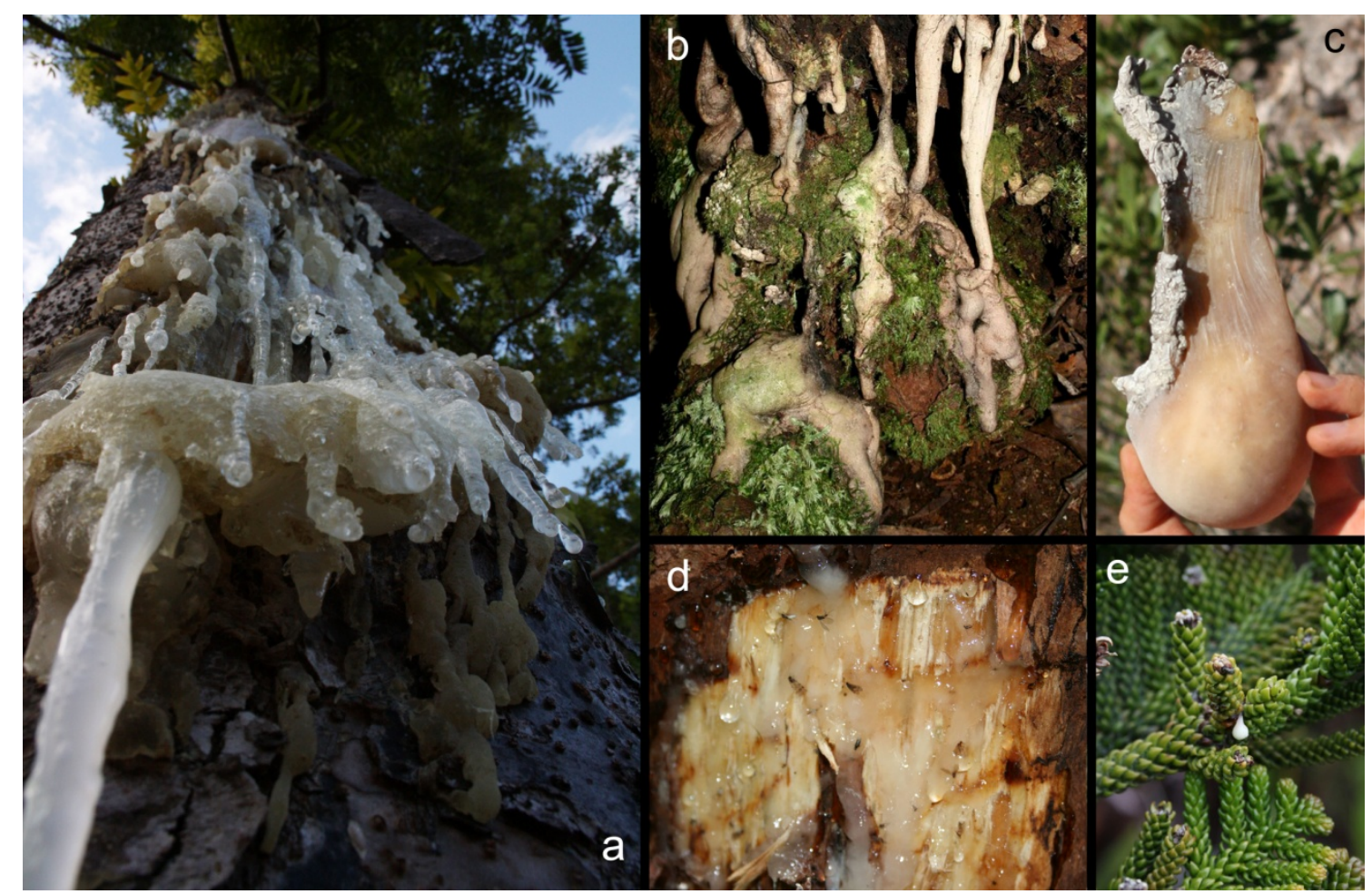

Figure 3. Various resin flows in extant conifers. (a) Resin flow at a wounded tree trunk of Agathis lanceolata, New Caledonia (b) Resin produced by roots of $A$. lanceolata, New Caledonia; flows are overgrown by abundant mosses, algae and resinicolous fungi (c) Recently solidified resin lump found at the treetop of Agathis ovata from New Caledonia. (d) Sticky resin flow with trapped insects at a wounded tree trunk of Pinus sylvestris, Germany (e) Resin drops produced by Araucaria humboldtensis due to insect infestation, New Caledonia.

However, several studies indicate that the degree of dehydration of engulfed organisms play a significant role for the quality of preservation (Henwood, 1992a, 1992b). Poinar and Hess (1982) considered that organic compounds such as sugars and terpenes in the resin might react with water from the tissues, which supports the dehydration hypothesis of the inclusion tissues. Resin flows are capable of trapping various kinds of organisms, depending on the size and location of both resin flows and organisms. Various plant species produce different resin flows and amounts (Fig. 3). The study of amberenclosed arthropods or remnants of plants from such fossilized resin flows is well established, but apart from those macroinclusions, amber even enables insights into 
microhabitats of Mesozoic and Cenozoic woodlands (e.g., Beimforde et al., 2011 [5]; Schmidt et al., 2010a; Schmidt et al.; 2006, Touvila et al., 2013 [2]; Sadowski et al., 2012 [3]). The fossil resin preserves morphological features of microorganisms with extraordinary fidelity; sometimes even cell organelles can be defined (Schmidt et al., 2006). Besides chert, amber is the only source of such well-preserved fossil soft-bodied microorganisms. As a special feature, amber preserved organisms from forest habitats, where fossilization processes rarely happened. Thus, the study of amber allows the tracing of the evolutionary history of organisms that are otherwise rarely or never preserved. Due to the exceptional preservation and hence microscopic fidelity, minute diagnostic features are often accessible, allowing a characterization and direct comparison of the fossil fungi to determinable extant taxa (e. g. Tuovila et al., 2013 [2]; Sadowski et al., 2012 [3]; Dörfelt and Schmidt, 2007).

Amber represents fossil tree resin that was produced by different conifers and angiosperms of the ancient "amber forests" of the Mesozoic and the Cenozoic. It is still a matter of debate why those trees produced such large amounts of resin. Different reasons have been suggested to explain the extensive resin productions of some former trees. As a reaction to physical damage like fire, resin may have been produced to close wounds (Meyer and Leney, 1968; Henwood, 1992b). Furthermore resin served as defense mechanism against microbial infections and infestations by insects such as weevils (True and Snow, 1949; Janzen 1975; Farrell et al., 1991). Storage of waste products from cellular metabolism or growth was also discussed (Henwood, 1993). Langenheim (1995) discussed a resin production as a protective barrier to reduce temperature and water loss. Additionally, an attraction of insect pollinators was hypothesized (Langenheim 1994; Gonçalves-Alvim, 2001).

However, those sticky flows served as ideal traps for organisms of Cenozoic and Mesozoic forest habitats. Arthropods and other organisms got stuck on the resin surface and were covered by subsequent resin flows. Diverse microorganisms such as bacteria, cyanobacteria, algae and fungi were also trapped in the resin flows. Single amber pieces containing various microorganisms are especially interesting for analyses of microbial interactions and life cycles of Mesozoic and Cenozoic ecosystems (e. g. Schmidt et al., 2006; Perrichot and Girard, 2009).

\subsection{Fossil ascomycetes from amber and chert}

The oldest fossil evidence of probable fungal structures showing septate anastomosing hyphae are described from the Proterozoic period and would extend the record of putative fungi to $1430 \mathrm{Ma}$ (Butterfield, 2005). Unfortunately, the mode of preservation does not allow satisfactory predictions of possible affiliations to recent fungal lineages. 
As mentioned in chapter 2.1, amber provides the exceptional potential to conserve fragile structures, like those of fungi. However, detailed windows into past fungal lineages are also provided by cherts, for instance the Devonian Rhynie chert (e. g. Krings et al., 2007) and various Carboniferous cherts (e. g. Taylor et al., 1994; Krings et al., 2009). So far only one example of ascomycetes, described by Taylor et al. (2005) as Paleopyrenomycites devonicus, was discovered from the Rhynie chert, but this fossil represents by far the oldest ( $\sim 400 \mathrm{Ma}$ ) fossil ascomycete.

The following paragraphs give an overview about the most important ascomycete fossils. Particulary in the last few years, many new excellently preserved fossil ascomycetes were found in Cretaceous to Miocene ambers. Due to the mode of preservation, these fossils are assignable to extant lineages and were utilized in this thesis to estimate divergence times of Ascomycete lineages by molecular clock models (chapter 5).

Fossil Dothideomycetes. Fossils resembling the extant genus Metacapnodium were found in ambers from eight Mesozoic and Cenozoic deposits (Schmidt et al., in review [4]). The genus Metacapnodium belongs to the ecological group of sooty moulds, a term that is commonly used for saprophytic fungi colonizing living plant surfaces by using exudates and honeydew of sap sucking insects (compare chapter 3.3). The diverse fossils allow to trace the morphological development of these fungi for approximately 100 million years. The oldest find is enclosed in Early Cretaceous amber (Albian, about 113 to $100 \mathrm{Ma}$ ) from Àlava and clearly represents a metacapnodiaceous sooty mould. The specimen (MCNA 9495) is housed in the Museo de Ciencias Naturales de Àlava in Spain.

The fossil parasitic fungus Petropus brachyphylli (NHMM RD 265, Natuurhistorisch Museum Maastricht, The Netherlands; see Fig. 1d in Beimforde et al. (submitted) [6]) was found in several silicified, detached conifer leaves of Brachyphyllum patens (van der Ham et al., 2003) and described by van der Ham and Dortangs (2005). The fossil leaves of the host plant are preserved in Late Maastrichtian (66.5 Ma) chert. Peteropus brachyphylli is considered a close relative of the extant Phaeocryptopus of the Venturiaceae. Species of this genus infect leaves of conifers belonging to the families Araucariaceae, Cupressaceae, Pinaceae and Podocarpaceae, which are seen as possible amber producing plants. The authors assumed that $P$. brachyphylli may have been closely associated with cheirolepidiaceous conifers, which became extinct near the end of the Cretaceous.

Fossil Eurotiomycetes. A fossil specimen of the anamorpic genus Aspergillus (Trichocomaceae, Eurotiales) was described as Aspergillus collembolorum (no. 805, Hoffeins collection Hamburg) by Dörfelt and Schmidt (2005). The species was growing 
on an enclosed springtail (Collembola) which is preserved in Eocene amber (50-35 Ma) from a Baltic deposit. Numerous extremely well preserved conidiophores with conidia are enclosed (see Fig. 1f in Beimforde et al., (submitted) [6]). A. collembolorum resembles representatives of the modern Aspergillus flavus group.

Several fossil species of the genus Chaenothecopsis are described from Oligocene and Eocene amber. Rikkinen and Poinar (2000) described a fossil species of Chaenothecopsis as C. bitterfeldensis (AF 9-26, Poinars collection, Oregon State University) from Bitterfeld amber, which represents an age of 23Ma. Over 20 stalked ascomata clearly represent the genus Chaenothecopsis and reflect the full range of ontogenetic stages. Two other species of Chaenothecopsis were described from Eocene Baltic (GZG.BST.27286) and Oligocene Bitterfeld amber (GZG, BST. BST.27285) dating back to 50-35 and 23 Ma, respectively (Tuovila et al., 2013 [2]) compare chapter 3.2). Both fossils are housed in the Geoscientific Collections of the Georg August University in Göttingen. The genus Chaenothecopsis belongs to the order Mycocaliciales and mainly contains species that live parasitic on free-living algae and lichens or live as saprobes on bark or lignum, but some species grow exclusively live on fresh or even on older resin flows (see chapter 3.2 and appendix [2]). The order Mycocaliciales is commonly placed in the Eurotiomycetes (Schoch et al., 2009). This phylogenetic position could be confirmed in this thesis when using only ribosomal gene markers, but differs when protein coding genes were involved. With those genes the used representatives of Mycocaliciales rather clustered within the Lecanoromycetes (see Fig. 2 in Beimforde et al., (submitted) [6]).

A plethora of septate, mostly four-celled and slightly curved conidia are enclosed in a piece of 93-95 million years old Ethiopian amber (MB. Pb. 2009/201, Museum für Naturkunde, Berlin) is described as Paleocurvularia variabilis (Schmidt et al., 2010b; see Fig. 1c in Beimforde et al. (submitted) [6]). The structures are most similar to those of the extant genus Curvularia (Eurotiales) but may also represent a species of the genera Bipolaris, Drechslaria, or Exserohilum. The genus Chochliobolus is recognized as the teleomorph of this anamorphic genus. Species of this hyphomycete genus are facultative pathogens and live as parasites on vascular plants, mainly in tropical regions but also in temperate areas.

Fossil Laboulbeniomycetes. A fossil species of the genus Stigmatomyces is described from the 23 million-year-old Bitterfeld amber deposit (Rossi et al., 2005). The fossil $S$. succini clearly resembles the genus Stigmatomyces and is attached to the thorax of a stalk-eyed fly (Prosphyracephala succini, Diopsidae). The genera Stigmatomyces (Laboulbeniaceae) belongs to the order Laboulbeniales in the class Laboulbeniamycetes, all members of which are known to live as ectoparasites on 
arthropods, mainly on insects. The holotype is located in the Zoologische Staatssammlung of Munich (see Fig. 1k in Beimforde et al., (submitted) [6]).

Fossil Lecanoromycetes. A fossil representative of the genus Anzia (Oschin 5/0, Michael Oschin's collection, Los Angeles) was described as A. electra by Rikkenen and Poinar (2002; see Fig. 1e in Beimforde et al. (submitted) [6]). The specimen is preserved in a piece of Eocene Baltic amber (55 - $35 \mathrm{Ma})$. The fossil appears morphologically similar to the extant species $A$. japonica. However, despite its extraordinary preservation and many similarities, the fossil cannot be assigned to $A$. japonica or to any other recent species. A confident assignment of A. electra would need to include features of secondary chemistry and for vegetative reproduction. The genus Anzia is morphologically very similar to the genus Pannoparmelia (Thell et al., 2010) an belongs to the family Parmeliaceae (Lecanorales), which is the largest family of lichen forming fungi, comprising more than 2000 species (Crespo et al., 2007). Due to morphological characteristics (deviating thallus), Anzia was segregated from Parmeliaceae as Anziaceae, but recent phylogenetic studies nested Anziaceae within Parmeliaceae (Arup et al., 2007).

Rikkenen (2003a) described a fossil Calicium (no. 1294 of the private collection of Volker Arnold, Heide, Germany) from the Baltic amber deposit dating back to 55 - 35 Ma. The fossil consists of a single detached ascoma and numerous spores (see Fig. $1 \mathrm{~g}$ in Beimforde et al. (submitted) [6]). The species is morphologically very similar to the modern species Calicium viride. The genus Calicium belongs to the so called calicioid lichens. Although this group is now known to be a paraphyletic assemblage, the term is still commonly used for fungi sharing morphological similarities such as stalked fruiting bodies and a mazaedium containing a powdery free spore mass (Tibell, 2003). Calicum is a genus within the family Caliciaceae which is closely related to the family Physciaceae (Wedin et al., 2002; Helms et al., 2003). Tibell (1984) explicitly described morphological delimitations of the genus Calicium, but since phylogenetic data are available, many species have been removed from the former order Caliciales. In recent classifications, the family Caliciaceae is assigned to the order Teloschistales in the Lecanoromycetes (Kirk et al., 2008).

Poinar et al. (2000) described two species of the family Parmeliaceae: Parmelia ambra (AF9-17E; (see Fig. 11 in Beimforde et al., (submitted) [6]) and P. isidiiveteris (AF9-17B Poinar collection of Dominican amber maintained at Oregon State University) from Dominican amber ( $\sim 17 \mathrm{Ma})$. Both fossils cannot with confidence be assigned to particular genera within the foliose parmelioid lichens ("Parmelia sensu lato").

A fossil specimen of Phyllopsora, described as Phyllopsora dominicanus (Poinar B 1-23, Poinar amber collection at the Oregon State University) by Rikkinen and Poinar 
(2008) is embedded in 17 million years old Dominican amber (see Fig. $1 \mathrm{~m}$ in Beimforde et al., (submitted) [6]). The morphological features of $P$. dominicanus closely resemble those of modern Phyllopsora species and seem to be most similar to recent $P$. chlorophaea. As many Phyllopsora species are quite phenotypically plastic, a reliable identification at species-level would need an additional chemical examination of the thallus. Species of the genus Phyllopsora are lichen-forming fungi and belong to the family Ramalinaceae in the Lecanoromycetes.

Fossil Sordariomycetes. Another fungal inclusion from Baltic amber (50-35 Ma) was found on a fossil spruce seedling and is described as Gonatobotryum piceae (no. F129/BB/F/CJW collection of Jörg Wunderlich, Germany) by Dörfelt and Schmidt (2007). The fungus infested a remnant of the hypocotyl and the basal parts of the cotyledons of the seedling (see Fig. $1 \mathrm{j}$ in Beimforde et al., (submitted) [6]). The preserved conidiophores show close similarities to the recent species Gonatobotryum fuscum. G. fuscum mainly occurs as parasite on bark and wood (Kirk et al., 2008). A further fossil species from Baltic amber shows close similarities to G. piceae and was describes by Caspary and Klebs (1907) as Gonatobotrys primigenia. Species of the anamorphic extant genera Gonatobotrys and Gonatobotryum are mainly mycoparasites. The ascomycete genus Melanospora (Ceratostomataceae, Sordariomycetes) is recognized as the teleomorph of Gonatobotrys species (Vakili, 1989). In contrast, no teleomorphs are currently known for Gonatobotryum species (Arx, 1981).

Fossil Ascomycetes with ambiguous systematic positions. Rikkinen (2003b) described a fossil species of the genus Chaenotheca (no. 1285 and 1294 of the private collection of Volker Arnold, Heide, Germany) also enclosed in Baltic amber (55 - 35 Ma). The fossilized lichen has a well developed thallus that was growing over a piece of bark (see Fig. 1h in Beimforde et al., (submitted) [6]). Six ascomata (four mature ones) have been well preserved in the amber. Even so, the fossil Chaenotheca was not assigned to any extant species because of its unknown photobiont identities and undeterminable ascus characteristics. The lichen genus Chaenotheca belongs to the family Coniocybaceae and is known for its association with four genera of photobionts: Dictyochloropsis, Stichococcus, Trentepohlia, and Trebouxia (Tibell, 2001). Like Calicium, Chaenotheca is part of the calicioid lichen group. The phylogenetic position of Chaenotheca is still enigmatic (Tibell and Koffmann, 2002). Phylogenetic analyses of this thesis based on ribosomal and protein coding genes revealed a grouping of Coniocybaceae and Lichinomycetes (see Fig. 2 and also Fig.1 in Beimforde et al., (submitted) [6]) but a denser taxon sampling would be needed to clarify the phylogenetic position of this group. 
Paleopyrenomycites devonicus is by far the oldest evidence of ascomycetes. It is preserved in 400 million years old Rhynie Chert from Scotland (Taylor et al., 2005). The fossil comprises perithecial ascomata with asci containing ascospores (see Fig. 1a in Beimforde et al., (submitted) [6]). Its perithecia are located beneath the epidermis in the outer cortical tissue of the host plant Asteroxylon. A closer assignment of $P$. devonicus to the Sordariomycetes was assumed by the authors, but its exact systematic position is still disputed (Taylor et al., 2005; Eriksson, 2005; Padovan et al., 2005; Taylor and Berbee, 2006). An assignment to the Pezizomycotina, the Pezizomycotina except Leotiomyceta (Schoch et al., 2009) or to the Pezizomycetes seems also possible (e.g. Lücking et al., 2009).

\section{Contributions to the systematics, taphonomy and palaeoecology of the Ascomycota}

The studies integrated in this section deal with systematics, taphonomy and palaeoecology of resin preserved ascomycetes and aim to elucidate the evolutionary history of the respective taxa. The respective publications are attached as appendices 1 to 5 .

\subsection{Fossil and recent resinous habitats}

In this study (Beimforde and Schmidt et al., 2011 [1]) various associations between microorganisms and fossil and recent resins are illustrated and discussed with the aim to enlighten embedding and conservation processes of microbial organisms in tree resin. For this purpose, microorganisms from inside and from the surface of modern and fossil resins were examined. The studies revealed three forms of associations between microorganisms and resins in which microorganisms (1) were enclosed by resin, (2) showed patterns of growth into the resin, and (3) colonized the resin surfaces.

Various limnetic and terrestrial microorganisms were found entirely embedded in modern resin of Pinus elliottii, a species from a Florida swamp forest that exhibits a massive natural resin production (Fig. 1a c in Beimforde and Schmidt, 2011 [1]). Those single celled limnetic organisms became enclosed, when the resin flowed down the tree trunks and reached the humid forest floor. Correspondingly, enclosed limneticterrestrial microorganisms have been reported from Cretaceous ambers (Schönborn et al., 1999; Dörfelt and Schäfer, 2000; Schmidt et al., 2004).

Additionally various fungal hyphae and filamentous bacteria were found in various fossil and recent resins (Fig. 2-6 in Beimforde and Schmidt, 2011 [1]). Many Cretaceous amber pieces are interspersed with fossil bacterial filaments, especially in 
their outer parts (Fig. 3 and 4 in Beimforde and Schmidt, 2011 [1]). Most of them are sheathed, branched cell chains that morphologically closely resemble the modern genus Leptothrix (Schmidt and Schäfer, 2005). Most likely these filamentous bacteria came into contact to the resin flows at the forest floor and used it as temporary habitat, probably by utilizing compounds of the resin as a nutrient source. Peñalver et al. (2007) described similar filamentous structures from Cretaceous amber as "alteration crust" and suggested them to be caused by weathering processes. According to the results of this study, those "crusts" of Cretaceous ambers are not caused by weathering but by microbial colonization. Experiments with living taxa convincingly demonstrated an active microbial growth, both bacteria and fungi, inside liquid gum of Cycas revoluta and resin of Pinus strobus two or three days after inoculation (Fig. 2e in Beimforde and Schmidt, 2011 [1]). Additionally, abundant fungal mycelia colonize recently solidified resin flows of Agathis lanceolata from New Caledonia (Fig. 2g-h and Fig. 5 in Beimforde and Schmidt, 2011 [1]), and those fungal hyphae most likely represent species of the family Mycocaliciaceae, a group of ascomycetes which includes several species that exclusively grow on resin and other exudates of vascular plants (Touvila et al., 2013 [2], Tibell and Titov, 1995).

Furthermore, living bacteria, fungi and algae were found at the surface and in cracks of amber pieces (Fig. 7 in Beimforde and Schmidt, 2011 [1]). Bacteria and fungi preferentially colonized impressions of the amber surface probably due to accumulated inorganic and organic matter that serve as a nutrient source. Whether components of the amber itself can be utilized as nutrient source is conceivable but has not been examined so far. Regarding the degradation of amber, processes of oxidation are probably decisive, but an additional microbial colonization may accelerate the degradation because chemical, physical and biological processes are triggered due to the microbial activity.

\subsection{A resinicolous species of Chaenothecopis with proliferating ascomata and its fossil ancestors}

In this paper (Tuovila et al., 2013 [2]), an extant species of Chaenothecopsis is decribed as $C$. proliferatus and compared with extant species and two new fossil specimens from Eocene Baltic and Oligocene Bitterfeld ambers dating back 35 and $23 \mathrm{Ma}$, respectively. The genus Chaenothecopsis belongs to the order Mycocaliciales (Eurotiomycetes). About $10 \%$ of all Chenothecopsis species exclusively grow on resin and other exudates of vascular plants (Tibell and Titov, 1995; Rikkinen, 1999; 2003b; Tuovila et al., 2011a; b), probably by utilizing compounds of the exudates as nutrient source (Rikkinen and Poinar, 2000). 
Chaenothecopsis proliferatus (Fig. 1-5 in Tuovila et al., 2013 [2]) was collected growing on resin of Cunninghamia lanceolata (Lamb.) Hook. (Cupressaceae) from Hunan Province, China. The phylogenetic relationship of $C$. proliferatus was analyzed using ribosomal gene regions (ITS, LSU) but its phylogenetic placement remains unclear (Fig. 6 in Tuovila et al., 2013 [2]).

The exquisite mode of preservations of both fossils described in this manuscript allowed a detailed comparison with extant relatives. The Oligocene fossil (Fig. 7 in Tuovila et al., 2013 [2]) had produced proliferating ascomata that are identical to those of $C$. proliferatus and to other extant species of the same lineage. In contrast, the Eocene species (Fig. 8 and 9 in Tuovila et al., 2013 [2]) shows non-proliferating ascoma. This fossil is represented by four immature and six mature ascomata which derive from a mycelium on the surface of a stalactite-like resin piece which served as substrate for the fungus. A subsequent resin flow buried the resinicolous specimen which demonstrates that the ability to rapidly exploit new substrates is advantageous, but also carries the inherent risk of being buried by its own substrate (Rikkinen and Poinar, 2000). The fossils show that resinicolous Chaenothecopsis species were already well adapted to their special ecological niche by the Eocene, and that the morphology of these fungi has since remained remarkably constant. The Oligocene fossil had produced proliferating ascomata identical to those of the newly described species from China and its extant relatives. This morphology may represent an adaptation to their life near exuding resin making it easy to rejuvenate if they were partly overrun by fresh resin. While many extant Chaenothecopsis species live on lichens and/or green algae, the fossils and the sporadic occurrence of resinicolous taxa in several distantly related extant lineages suggests that the early diversification of Mycocaliciales may have occurred on plant substrates.

\subsection{A fossil and a recent representative of the anamorphic genus Monotosporella}

This paper (Sadowski et al., 2012 [3]) deals with a fossil and recent species of the anamorphic ascomycete genus Monotosporella. All species of this genus are saprophytic and have a worldwide distribution (e.g., Sivichai et al., 1998; Raja et al., 2007). They are mostly found on decaying wood that is submerged in water (Sivichai et al., 1998, Tsui et al., 2001), but also occur on woody plants (Rao and de Hoog, 1986; Raja et al., 2007). Species of Monotosporella are generally distinguished by the size and shape of their conidiophores, conidia and conidiogenous cells (Ranghoo et al., 1999, Hughes, 1978, Yanna and Hyde, 2002). Since the teleomorph state of Monotosporella, Ascotaiwania was discovered (Ranghoo and Hyde, 1998; Sivichai et al., 1998) they are 
now placed in the Annulatascaceae of the Sordariomycetes. No sequence data of Monotosporella can corroborate this placement, so far, and attempts in this thesis to obtain sequence data from the extant New Caledonian species failed since too few conidia were available for DNA extraction.

The fossil Monotosporella is described as M. doerfeltii (see Fig. 1 and 2 in Sadowski et al., 2012 [3]) and represents the second fossil record of Sordariomycetes, as well as the first fossil of its particular order (either Savoryellales or Chaetosphaeriales). It was found enclosed in 52 million-year-old amber from the Tarkeshwar Lignite Mine of Gujarat State, western India. Inclusions of the Indian amber represent a part of the biota of an early tropical angiosperm rainforest. During the Early Eocene India was covered by a dense, multi-storied rain forest (Morley, 2000; Collinson, 2003) in which the uppermost tree species belonged to the resin-producing family Dipterocarpaceae (Rust et al., 2010).It is most likely that $M$. doerfeltii was growing on a degrading Cladonialike lichen thallus in a corticolous or terrestrial microhabitat of this early tropical angiosperm rain forest.

Morphological similarities were drawn between the fossil $M$. doerfeltii and an extant species of Monotosporella which was found on fresh resin flows of Agathis ovata in New Caledonia. This recent species could be assigned to Monotosporella setosa. Actually, it is the first time that a species of Monotosporella is recorded from resinous habitats. So far, resinicolous life styles were exclusively known from members of the order Capnodiales and representatives of Mycocaliciales (Tuovila et al., 2013 [2]). It is not clear if species of Monotosporella may exhibit the same grade of substrate specification as it is proposed for several of the above mentioned species such as Cheanothecopsis (Tibell and Titov, 1995; Tuovila et al., 2011a; b). However, our recent finds from different resinous habitats demonstrates that the genus is ecologically variable, with occurrences of Monotosporella in both early tropical angiosperm forests and extant tropical araucarian forests.

\subsection{A compilation of fossil sooty moulds}

The term sooty moulds is commonly used for saprophytic fungi forming extensive subicula with dark brown hyphae on living plant surfaces subsisting from plant exudates and honeydew of sap sucking insects (Seifert et al., 2011). This fungal group mainly involves capnodialean species (Capnodiales, Dothideomycetes) from the families Antennulariellaceae, Capnodiaceae, and Metacapnodiaceae, but also includes other species that share ecologically and morphologically similar traits.

In this manuscript (Schmidt et al., (in review) [4]) a compilation of diverse metacapnodian fossils from eight northern hemispheric Mesozoic and Cenozoic deposits is presented. These various finds of fossils of capnodialean sooty moulds 
allowed tracing the fossil record of this fungal group back for approximately 100 million years, from the Early Miocene (17 million years) back to the Early Cretaceous (Albian, about 113 to 100 million years).

The fossil sooty moulds described in this manuscript are preserved in amber from various deposits and most probably grew on different trees. Most of them have probably grown epiphytically on the bark or leaves of the amber-producing tree or on neighbouring trees. Others lived as hyperepiphytes on corticolous lichens and bryophytes, which is also known for extant species (e.g. Braun et al., 2009). The ancient fungi were probably trapped in the resin when it exuded over bark or when fragments of the fungal subicula became detached and dropped onto fresh resin on the tree trunk or forest floor.

The presence of sooty mould species generally indicates a certain degree of humidity. Typically, Cretaceous forests even in the tropics received less rainfall than modern angiosperm-dominated rainforests (Boyce et al., 2010). The finding of fossil sooty moulds from mid-Cretaceous ambers suggests that those coastal 'amber forests' probably received additional moisture in form of frequent coastal fog or local rainfall.

The oldest founds of sooty moulds come from the Early Cretaceous 110 million years ago (Àlava, San Just and Archingeay) which was the time when early angiosperms diversified in forest ecosystems (Crane, 1987). The rise of angiosperms changed the climate conditions of Cretaceous forests in the form of increasing humidity (Boyce et al., 2010) which has probably favoured the growth of metacapnodiaceous species. Additionally, the increase of broad-leaved plant species opened up further niches and food sources for plant sap sucking insects (aphids and scale insects), which consequently created new habitats for sooty moulds (Rikkinen et al., 2003). However, the association between plant-sucking insects and sooty moulds may have evolved in pre-Cretaceous times, because insect excretions as potential nutrition source were available much earlier (Labandeira, 2006; Szwedo and Nel, 2011; Nel et al., 2012).

Saprobic genera represent the earliest diverging lineages among extant capnodialean fungi and this nutritional style is assumed to be an ancestral mode of this group (Crous et al., 2009). Additionally, the morphological similarity of Early Cretaceous sooty moulds and extant taxa suggests that they might represent an ancient component of humid forest ecosystems. The lack of pre-Cretaceous sooty mould fossils may well be a sampling artifact because of the limited amounts of pre-Cretaceous amber.

\subsection{The first fossil ectomycorrhizae associated with an angiosperm}

Fossil ectomycorrhizae (ECM) are preserved in amber from a tropical angiosperm tree of the family Dipterocarpaceae of likely Gondwanan origin (Beimforde et al., 2011 [5]). The amber was recovered from Early Eocene (52 million year-old) sediments at the 
Tadkeshwar Lignite Mine in Gujarat, western India (Rust et al., 2010). About 20 unramified to monopodial-pinnate ectomycorrhizal systems are fossilized adjacent to several rootlets and different developmental stages of the ectomycorrhizae are preserved in this single piece of amber (Fig. 1 in Beimforde et al., 2011 [5]). Dissolving the surrounding amber from parts of the ectomycorrhizal system allowed a detailed study of the fossil by scanning electron microscopy (Fig. 2 Beimforde et al., 2011 [5]). The exposed fossil hyphae were analyzed by Raman spectroscopy revealing traces of fossil melanin in the dark hyphae (Fig. 4 Beimforde et al., 2011 [5]). This was the first time that melanin could be detected from a fossil fungus.

The mycobiont of this fossil symbiosis is considered to be an ascomycete anamorph because narrow perforations are present in the septae, while clamp connections are absent (Fig. S1H in Beimforde et al., 2011 [5]). The black color of the hyphae is similar to the extant ascomycete genus Cenococcum, whose only species, however, forms mostly unbranched ECM with modern phytobionts. The fossil ectomycorrhizae was therefore described as Eomelanomyces cenococcoides.

Besides ascomycetes, all glomeromycetes and several basidiomycetes form symbiotic cooporations with vascular plant roots. Those mycorrhizial associations are ubiquitous in terrestrial ecosystems and constitute a crucial part concerning the evolution of terrestrial life on earth, especially in terms of plants. In fact, up to $90 \%$ of all vascular plants live in a mutualistic association with fungi (Pirozynski and Malloch 1975; Malloch et al., 1980; Wang et al., 2010). This symbiosis is considered to be a key innovation of early land plants that enabled them to extensively colonize terrestrial habitats (e.g. Cairney, 2000; Wang et al., 2010).

Various forms of mycorrhizae have evolved over the course of time (Brundrett, 2002). Endomycorrhizae, in which the fungus forms intracellular vesicles and arbuscles, are recorded since the Early Devonian (Remy et al., 1994). Ectomycorrhizae, in which the fungus does not penetrate living cells, as well as ericoid and orchid mycorrhizae, seem to have evolved subsequently in response to changing environments and the appearance of possible new fungal symbionts (Cairney, 2000, Hibbett and Matheny 2009).

Endomycorrhizae are typically predominant in modern tropical forests, but some ectomycorrhizal symbioses are very successful, cover a large portion of the total area (e.g. Newbery et al., 1988), and sometimes even dominate tropical rainforests (Connell and Lowman, 1989). However, several ecologically important tropical plant families including the amber-producing Dipterocarpaceae are obligatorily ectomycorrhizal. The paleogeographic and temporal origin of Dipterocarpaceae and their history of association with ectomycorrhizal fungi have frequently been discussed (Ducousso et al., 2004; Moyersoen, 2006). Dipterocarps are likely to have originated in eastern Africa or 
Madagascar (Dutta et al., 2011). After the Indian landmass separated and drifted northward, they reached Asia during the Eocene and spread.

The fossil Eomelanomyces cenococcoides reveals the occurrence of angiosperm ectomycorrhizae in the Paleogene tropics and supports the hypothesis of an ancestral ectomycorrhizal stage of the Dipterocarpaceae. In fact, ectomycorrhizae may have conferred an evolutionary advantage on dipterocarps, allowing them to become the dominant tropical hardwood trees in India as the landmass moved over the equator and finally interacted with Asia, so that they subsequently spread into South East Asia, where they still predominate today, constituting $80 \%$ of the canopy.

Mycorrhizae are unstable associations and evolved independently within the family Pinaceae and several times in the angiosperm clade that includes Rosids and Asterids (Fitter and Moyersoen, 1996). This was probably also influenced by changing environmental conditions, and by the appearance of possible new fungal symbionts (Hibbett and Matheny, 2009; Moyersoen et al., 2001; Cairney, 2000). Consequently, E. cenococcoides itself is not necessarily an ancestral mycobiont of its host.

The basal geographic origins of ectomycorrhizae have remained unclear, but the ectomycorrhizal symbiosis that evolved with the exclusively northern hemispheric Pinaceae may be one of the earliest; the only previously reported fossil record of ectomycorrhizae is actually from roots of Eocene Pinaceae on Vancouver Island (LePage et al., 1997). However, our fossil suggests that ectomycorrhizae were contemporaneous in tropical angiosperm forests of Gondwanan origin, and that ectomycorrhizae may have developed independently in Laurasia and Gondwana.

\section{Tracing lineages with molecular methods}

\subsection{Fossil DNA in amber: is there a chance?}

The exceptionally preservation of organisms in amber has often lead to the conclusion that DNA molecules of enclosed organisms might be intact and amplifiable. This is a very appealing speculation, but unfortunately it could not be confirmed by any study, so far. Even an amplification of DNA from copal (semi-fossil resin) failed, whereupon Austin et al. (1997) concluded that resin is not capable of the preservation of complex molecules such as DNA, although the morphological structures are recorded very well. Besides, non-degraded modern molecules are always preferred during the polymerase chain reaction, making an amplification of fragments of ancient DNA highly unlikely. It is assumed that amplifiable DNA does generally not persist much longer than several thousands of years (Hofreiter et al., 2001, Willerslev et al., 2004, Willerslev and Cooper, 2005, Allentoft et al., 2012). 
In the 1990s, several attempts have been made to amplify DNA from amberpreserved insect and plant inclusions (e.g., Cano et al., 1994; Poinar and Poinar, 1994; Lambert et al., 1998; Greenblatt et al., 1999). However, it turned out, that the DNA obtained in these studies was modern contamination. Greenblatt et al. (2004) demonstrated that it is difficult or almost impossible to get the amber free of modern DNA and RNA since bacteria, fungi and other microbes remain in fissures, even after surface sterilization by ultrasonic cleaning, $\mathrm{H}_{2} \mathrm{O}_{2}$ and ethanol (for protocols see Lambert et al., 1998). Greenblatt et al. (1999; 2004) noticed that putative fossil microorganisms that were isolated from different ambers were actually much younger than the amber itself. Consequently, they suggested that those microorganisms exist as contaminants in amber cracks instead of being fossil microinclusions.

\subsection{Molecular clock models for fungi}

Molecular clock methods have greatly improved over the last few years and serve as a remarkable tool that allows more and more accurate predictions about the unrecorded prehistory of considered lineages. New methods such as relaxed clocks (Drummond and Rambaut, 2007) consider different evolution rates for individual lineages and allow an implementation of minimum and maximum age constraints for one or for several calibration points (Ho, 2007; Benton et al., 2009; Inoue et al., 2010; Magallon, 2010; Heled and Drummond, 2012; Lukoschek et al., 2012). Those studies integrate the information that is used for calibration (e.g. from fossils) in form of probability distributions.

So far, various studies have been carried out to estimate the origin and evolution of major lineages (e.g. Douzery et al., 2004; Schneider et al., 2004; Magallón and Sanderson, 2005; Donoghue and Benton, 2007; Ramírez et al., 2007, Wikström et al., 2010; Nauheimer et al., 2012) and several attempts have been made to date the temporal origin and evolution of main fungal lineages by molecular clock methods (e. g. Simon et al., 1993; Redecker et al., 2000; Heckman et al., 2001; Berbee and Taylor, 1993; 2007; Taylor and Berbee, 2006; Padovan et al., 2005; Lücking et al., 2009; Gueidan et al., 2011; Fouldas et al., 2012; Ohm et al., 2012).

Compared to early molecular evolution studies of fungi, recent studies are much more congruent. This is likely to be due to improvements in developing relaxed molecular clock models, but also due to more well resolved fungal phylogenies that have been established over the last decade (e. g. Hibbett et al., 2007). However, despite the improvements in methodology and data sampling, the resulting age estimates are not fully consistent across recent studies. Such discrepancies are due to a variety of reasons, such as possible inability to properly model evolutionary rates, parameter settings for 
the applied relaxed clock models, unequal taxon sampling, and choice of genes under study.

Many studies of molecular evolution showed the importance of constraining the molecular clocks with reliable fossil evidence (Benton et al., 2009; Hedman, 2010; Inoue et al., 2010; Magallon, 2010; Pyron, 2010; Wilkinson et al., 2011; Lukoschek et al., 2012; Sauquet et al., 2012, Feldberg et al., 2013). One important requirement for the use of fossils as minimum age constrains is their accurate placement to corresponding nodes in the chosen phylogeny (Rutschmann et al., 2006; Marshall, 2008; Forest, 2009; Praham et al., 2012; Pyron, 2010; Dornberg et al., 2011). This requires information about their systematic position and age of selected fossil species/material. In this regard, fossils preserved in amber and cherts provide excellent conditions. Amber and cherts may conserve delicate structures of organisms regardless of their susceptibility to decay (Stankiewicz et al., 1998; Martínez-Delclós et al., 2004). Even very fragile diagnostic features, like those of fungi, are preserved and can be compared to recent species with great detail. The following chapter provides an overview of a study (Beimforde et al., submitted [6]) in which available fossil ascomycetes from amber and chert are utilized to constrain a molecular clock for the Ascomycota.

\subsection{Using fossil ascomycetes from amber and chert to estimate the Phanerozoic history of the Ascomycota}

In this manuscript (Beimforde et al., (submitted) [6]), all of the oldest available ascomycete fossils from amber and chert were reinvestigated with respect to their potential use as minimum age constraints for models of molecular evolution. These fossils (see Fig. 1 in Beimforde et al., (submitted) [6]) represent several major lineages of the ascomycetes (Caliciaceae, Parmeliaceae, and Ramalinaceae of the Lecanoromycetes; Laboulbeniaceae of the Laboulbeniomycetes; Metacapnodiaceae and Pleosporaceae of the Dothideomycetes; Trichocomaceae and Venturiaceae of the Eurotiomycetes, in addition to two smaller groups of uncertain position, i.e., the Coniocybaceae and Mycocaliciaceae) and are preserved in amber from various deposits spanning an Albian to Miocene age (about 113 to 17 million years old) as well as in Devonian and Maastrichtian cherts (about 410 and 66.5 million years old, respectively).

Six of the reinvestigated fossil specimens were used to constrain a molecular clock model for an Ascomycota phylogeny. To combine the fossil data with molecular data, a multi-gene data set (18SrDNA, 28SrDNA, RPB1 and RPB2) with a total of 145 modern taxa representing the main groups of the Ascomycota was assembled. A Bayesian approach was used (BEAST) to implement the fossil data as minimum age constraints in order to estimate the divergence times of the main ascomycete classes. The 
extraordinary preservation of the fossil ascomycetes allowed a precise assignment of the fossils to particular nodes in the phylogeny under study (see Fig. 1 in Beimforde et al., (submitted) [6]). To evaluate the influence of our internal node constraints, two analysis with identical parameter settings were performed in which the Devonian fossil Paleopyrenomycites devonicus (Tayor et al., 2005) was either used as the sole constraint for Pezizomycotina or in addition to further ascomycotan fossils.

The resulting age estimates (see Fig. 2 and supplementary Fig. 1 in Beimforde et al., (submitted) [6]) were exclusively based on internal age constraints (either one or six) but largely agree with estimates in recent studies that employed external (nonascomycotan and/or non-fungal) constraints (Berbee and Taylor 2006; Lücking et al., 2009; Gueindan et al., 2010). The results show that minimum age constraints in terminal groups of the Ascomycota significantly affect the estimated divergence times of both early branching nodes and nodes of terminal groups of Ascomycota lineages by pushing them back in time (see table 2 in Beimforde et al. (Table 2) [6]). The results indicate that further inclusions of reliable fossil constraints are likely to lead to even more accurate estimated ages of individual lineages. According to the resulting age estimates from the multiple calibration study, the diversification of the Pezizomycotina started in the Cambrian, and was followed by a continuous diversification of ascomycetes throughout the Phanerozoic that was likely to have been unaffected by mass extinctions. We suggest that the ecological diversity within each lineage ensured that at least some taxa of each group were able to survive global crises such as mass extinctions and rapidly recovered.

\section{Conclusions and outlook}

The investigation of amber inclusions has made great advances and many new taxa have been described in the last few years. The studies involved in this thesis demonstrate the great potential of fossil Ascomycota from amber in order to trace the evolutionary history this large group of fungi. The newly described taxa involved in this thesis (Beimforde et al., 2011 [5]; Touvila et al., 2013 [2]; Sadowski et al., 2012 [3], Schmidt et al., (submitted) [4]) are among the oldest evidence for the respective Pezizomycotina lineages and provide the most detailed descriptions of those fossil Pezizomycotina. The results contribute to the increasing information about ascomycotan life in Phanerozoic ecosystems. They provide information of interactions such as mycorrhizae (Beimforde et al., 2011 [5]) between ascomycotan fungi and other organism of the respective ecosystems. These results may also provide a template for further research since a large amount of material is available for further research. The steady accumulation of newly discovered fossils from worldwide amber deposits will allow further enlightenment of 
the Phanerozoic history of the Ascomycota. The results of this thesis further contribute to the knowledge about the taphonomy of amber preserved fungi and other microorganisms by investigating associations between microorganisms and fossil and recent resins (Beimforde and Schmidt, 2011 [1]). This study emphasizes an active growth of microorganisms in liquid resins and on solidified resin surfaces.

Additionally, the results of this thesis (Beimforde et al., [submitted) [6]) show the great potential of amber fossils for constraining molecular clock models. The delicate preservation of fossil Pezizomycotina in amber and chert enabled a very precise assignment of the fossil specimens in a recent Ascomycota phylogeny. The unresolved relationships for some Pezizomycotina classes in the Ascomycota phylogeny restricted comparisons of divergence times between some classes belonging to the super class Leotiomyceta. Improved phylogenetic studies, larger taxon sampling and the integration of a more comprehensive fossil record is likely to lead to more reliable results. For this reason a continuous screening of newly discovered ambers and cherts is needed to accumulate determinable fossils of fungi which are likely to improve molecular evolution models for fungal phylogenies, especially for individual groups of fungi. 


\section{Acknowledgements}

I am very grateful to my advisor Alexander Schmidt for giving me the opportunity to work in such an exciting research field, for sharing his knowledge about fossil microorganisms, and for the critical but very constructive discussions. I would like to thank Joachim Reitner for giving me the opportunity to work in his lab and for his helpful advice.

I sincerely thank Kathrin Feldberg, Stephan Nylinder, Matthias Gube and Daniel Jackson for their discussions and technical support in terms of phylogenetics and molecular evolution. Heinrich Dörfelt, Jouko Rikkinen and Hanna Tuovila are thanked for their helpful advices regarding the systematics of fossil and extant fungi.

For proof reading and for sharing her broad knowledge about fossils and plants I thank Leyla Seyfullah. Thomas Bode was always very helpful in all kinds of computer and software support. For discussions, literature, support with field works or with technical equipment I am indebted to Jennifer M. Bannister, Wolfgang Dröse, David Grimaldi, Linn Groenevelt, Axel Hackmann, Daphne E. Lee, Jon Lindqvist, Luciana Macis, Paul Nacimbene, Nadia Valérie Queric, Mike Reich, Dorothea Hause Reitner, Birgit Röhring, Regine Sammel and Nadine Schäfer.

I am indebted to all my colleagues and friends that contributed to the success of this study. Sincere thanks are given to Jennifer Hohagen, Christine Heim, Ines Herlitze, Nora Glaubrecht, Mahesh Desai, Juliane Germer, Eva-Maria Sadowski for their encouragement and nice coffee break and chats.

For the everlasting support and encouragement I am deeply indebted to Uwe Kaulfuß and to my family, especially to my parents. Thank you so much for your love and for your endless and uncomplaining support in every aspect. 


\section{References}

Adl, SM et al. (2005) The new higher level classification of eukaryotes with emphasis on the taxonomy of protists. Journal of Eukaryotic Microbiology 52, 399-451.

Allentoft ME, Collins M, Harker D, Haile J, Oskam CL, Hale ML, Campos PF, Samaniego JA, Gilbert MTP, Willerslev E, Zhang G, Scofield RP, Holdaway RN, Bunce M. (2012) The half-life of DNA in bone: measuring decay kinetics in 158 dated fossils. Proceedings of the Royal Society, Series B 279, 4724-4733.

Arndt E, Rossi W, Zerm M (2003) A new species of Laboulbenia parasitic on tiger beetles. Mycological Progress 2 123-126.

Arup U, Ekman S, Grube M, Mattsson J-E, Wedin M (2007) The sister-group relation of Parmeliaceae (Lecanorales, Ascomycota). Mycologia 99, 42-49.

Arx JA (1981) The genera of fungi sporulating in pure culture. Vaduz: J. Cramer.

Austin J, Ross AJ, Smith AB, Fortey RA, Thomas RH (1997) Problems of reproducibility - does geologically ancient DNA survive in amber-preserved insects? Proceedings Royal Society London, Series B Biological Science 264, 467-621.

Baldauf SL, Roger AJ, Wenk-Sierfert I, Doolittle WF (2000) A kingdom-level phylogeny of eukaryotes based on combined protein data. Science 290, 972-977.

Bapteste E, et al. (2001) The analysis of 100 genes support the grouping of three highly divergent amoebae: Dictyostelium, Entamoeba, and Mastigamoeba. Proceedings of the National Academy of Sciences USA 99, 1414-1419.

Barr ME (1983) The ascomycete connection. Mycologia 75, 1-13.

Beimforde C (2011) Biodeterioration (of Stone). In: Reitner J, Thiel V (eds), Encyclopedia of Geobiology, Springer-Verlag, Heidelberg, pp 112-117.

Beimforde C, Schmidt AR (2011) Microbes in Resinous Habitats: A Compilation from Modern and Fossil Resins. In: Reitner J, Queric N-V, Arp G (eds) Advances in Stromatlite Geobiology. Lecture Notes in Earth Sciences. 131, 391-407.

Beimforde C, Schäfer N, Dörfelt H, Nascimbene PC, Singh H, Heinrichs J, Reitner J, Rana RS, Schmidt AS (2011) Ectomycorrhizas from a Lower Eocene angiosperm forest. New Phytologist 192, 988-996.

Beimforde C, Feldberg K, Nylinder S, Rikkinen J, Tuovila H, Dörfelt H, Gube M, Jackson D, Reitner J, Seyfullah LJ, Schmidt AR (submitted). Estimating the Phanerozoic history of the Ascomycota lineages: combining fossil and molecular data. Molecular Phylogenetics and Evolution.

Benton MJ, Donoghue PCJ, Asher RJ (2009) Calibrating and constraining molecular clocks. In: Hedges SB, Kumar S (eds) Timetree of Life. University Press, Oxford, pp $35-86$. 
Berbee ML (1996) Loculoascomycete origins and evolution of filamentous ascomycete morphology from 18SrRNA gene sequence data. Molecular Biology and Evolution $13,462-470$.

Berbee, ML, Taylor, JW (1993) Dating the evolutionary radiations of the true fungi. Canadian Journal of Botany 71, 1114-1127.

Berbee, ML, Taylor, JW (2007) Rhynie chert: a window into a lost world of complex plant-fungus interactions. New. Phyt. 174, 475-479.

Berbee ML, Taylor JW (2010) Dating the molecular clock in fungi - how close are we? Fungal biology reviews 24, 1-15.

Bergsten J (2005) A review of long-branch attraction. Cladistics 21 163-193

Blackwell M (2011) The Fungi: 1, 2, 3 ... 5.1 Million Species? American Journal of Botany 98, 426-438.

Boyce CK, Lee JE, Field TS, Brodribb TJ, Zwieniecki MA (2010) Angiosperms helped put the rain in the rainforests: The impact of plant physiological evolution on tropical biodiversity. Annals of the Missouri Botanical Garden 97, 527-540.

Braun U, Heuchert B, Diederich P (2009) Two new and another interesting lichenicolous hyphomycete. Herzogia 22, 165-171.

Brazee NJ, Marra RE, Wick RL (2012) Genotypic diversity of Armillaria gallica from mixed oak forests in Massachusetts. Mycologia 104, 53-61.

Brundrett MC (2002) Coevolution of roots and mycorrhizas of land plants. New Phytologist 154, 275-304.

Butterfield NJ (2005) Probable Proterozoic fungi. Paleobiology. 31 165-182.

Cairney JWG (2000) Evolution of mycorrhiza systems. Naturwissenschaften 87, 467-475.

Cano RJ, Borucki MK, Higby-Schweizer M, Poinar HN, Poinar GO Jr, Pollard KJ (1994) Bacillus-DNA in fossil bees: an ancient symbiosis? Applied and Environmental Microbiology 60, 2164-2167.

Caspary R, Klebs R (1907) Die Flora des Bernsteins und anderer fossiler Harze des ostpreussischen Tertiärs. Berlin: Königlich Preußische Geologische Landesanstalt, Neue Folge, Heft 4.

Celio GJ, Padamsee M, Dentinger BT, Bauer R, McLaughlin DJ (2006) Assembling the Fungal Tree of Life: constructing the structural and biochemical database. Mycologia 98, 850-9.

Collinson ME (2003) Rise of modern land plants and vegetation. In: Briggs DEG, Crowther PR (eds) Palaeobiology II. Blackwell Science, Oxford pp 112-115.

Connell JH, Lowman MD (1989) Low-diversity tropical rain forests: some possible mechanisms for their existence. American Naturalist 134 88-119.

Copeland HF (1938) The kingdoms of organisms. Quarterly Review of Biology 13, 383420. 
Copeland HF (1956) The Classification of Lower Organisms. Pacific Books, Palo Alto.

Cordeiro LMC, Reis RA, Cruz LM, Stocker-Wörgötter E, Grube M, Iacomini M (2005) Molecular studies of photobionts of selected lichens from the coastal vegetation of Brazil. FEMS Microbiol Ecol 54, 381-390.

Crane PR (1987) Vegetational consequences of the angiosperm diversification. In: Friis EM, Chaloner WG, Crane PR (eds) The origins of angiosperms and their biological consequences. University Press, Cambridge, pp 107-144.

Crespo A, Lumbsch TH, Mattsson J-E, Blanco O, Divakar PK, Articus K, Wiklund E, Bawingan PA, Wedin M (2007) Testing morphology-based hypotheses of phylogenetic relationships in Parmeliaceae (Ascomycota) using three ribosomal markers and the nuclear RPB1 gene. Molecular Phylogenetics and Evolution 44, 812-824.

Crous PW, Schoch CL, Hyde KD, Wood AR, Gueidan C, de Hoog GS, Groenewald JZ (2009) Phylogenetic lineages in the Capnodiales. Studies in Mycology 64, $17-47$.

Cusimano N, Stadler T, Renner SS (2012) A new method for handling missing species in diversification analysis applicable to randomly or non-randomly sampled phylogenies. Systematic Biology 61, 785-792.

Delsuc F, Brinkmann H, Philippe H (2005). Phylogenomics and the reconstruction of the tree of life. Nature Reviews Genetics, 361-375.

Donoghue PCJ, Benton MJ (2007) Rocks and clocks: calibrating the Tree of Life using fossils and molecules. Trends in Ecology and Evolution 22, 424-431.

Dörfelt H, Schäfer U (2000) Palaeozygnema spiralis, ein Vertreter der Conjugatophyceae in mesozoischem Bernstein aus Bayern. Hoppea 61 785-793.

Dörfelt H, Schmidt AR (2005) A fossil Aspergillus from Baltic amber. Mycolgical Research 109, 956-960.

Dörfelt H, Schmidt AR (2007) A conifer seedling with two herbicolous fungi from the Baltic amber forest. Botanical Journal of the Linnean Society 155 449-456.

Dornberg A, Beaulie JM, Oliver JC, Near TJ (2011) Integrating fossil preservation biases in the selection of calibrations for molecular divergence time estimation. Systematic Biology 60, 519-527.

Douzery EJP, Snell EA, Bapteste E, Delsuc F, Philippe H (2004) The timing of eukaryotic evolution: Does a relaxed molecular clock reconcile proteins and fossils? Proceedings of the National Academy of Sciences, USA 101, 15386-15391.

Drummond AJ, Rambaut A (2007) BEAST: Bayesian evolutionary analysis by sampling trees. BMC Evolutionary Biology 7, 214.

Drummond AJ, Ho SY, Rambaut A (2006) Relaxed phylogenetics and dating with confidence. PLoS Biology 4, e88.

Ducousso M, Béna G, Bourgeois C, Buyck B, Eyssartier G, Vincelette M, Rabevohitra R, Randrihasipara L, Dreyfus B, Prin Y (2004) The last common ancestor of 
Sarcolaenaceae and Asian dipterocarp trees was ectomycorrhizal before the India Madagascar separation, about 88 million years ago. Molecular Ecology 13, 231-236.

Dutta S, Tripathi SM, Mallick M, Mathews RP, Greenwood PF, Rao MR, Summons RS. (2011) Eocene out-of-India dispersal of Asian dipterocarps. Review of Palaeobotany and Palynology 166, 63-68.

Ebersberger I, de Matos Simoes R, Kupczok A, Gube M, Kothe E, Voigt K, von Haeseler A, 2012. A consistent phylogenetic backbone for the fungi. A. Molecular Biology and Evolution 29, 1319-1334.

Eriksson OE (2005) Origin and evolution of Ascomycota - the protolichenes hypothesis. Svensk Mykol Tidskr 26, 30-33.

Eriksson OE (2006) Outline of Ascomycota-2006. Myconet 121-82.

Farrell BD, Dussourd DE, Mitter C (1991) Escalation of plant defense: Do latex/resin canals spur plant diversification? American Naturalist 138 881-900.

Feldberg K Heinrichs J, Schmidt, AR, Váòa J, Schneider H (2013) Exploring the impact of fossil constraints on the divergence time estimates of derived liverworts. Plant Systematic and Evolution 299, 585-601.

Fitter AH, Moyersoen B (1996) Evolutionary Trends in root microbe symbiosis. Philosophical Transactions of the Royal Society B 351, 1367-1375.

Fitzpatrick DA, Logue ME, Stajich JE, Butler G (2006) A fungal phylogeny based on 42 complete genomes derived from supertree and combined gene analysis. BMC Evolutionary Biology 6, 99.

Floudas D et al. (2012) The Paleozoic Origin of Enzymatic Lignin Decomposition Reconstructed from 31 Fungal Genomes. Science, 336 1715-1719.

Forest F (2009) Calibrating the Tree of Life: fossils, molecules and evolutionary timescales. Annals of Botany 104, 789-794.

Frickhinger KA (1994) The Fossils of Solnhofen. Goldschneck, Weinstadt, BademWürtemberg.

Geiser DM, MiadlikowskaJ, Lutzoni F, Kauff F, Hofstetter V, Fraker E, Schoch CL, Tibell L, Untereiner WA, Aptroot A (2006) Eurotiomycetes: Eurotiomycetidae and Chaetothyriomycetidae. Mycologia 98, 1053-1064.

Goloboffa, PA, Carpenterb JM, Salvador Ariasc J, Rafael D, Esquivel M (2008) Weighting against homoplasy improves phylogenetic analysis of morphological data sets. Cladistics 24, 758-773.

Gonçalves-Alvim SD (2001) Resin-collecting bees (Apidae) on Clusia palmicida (Clusiaceae) in a riparian forest in Brazil. Journal of tropical Ecology 17, 149-153.

Greenblatt CL, Davis A, Clement BG, Kitts CL, Cox T, Cano RJ (1999) Diversity of microorganisms isolated from amber. Microbial Ecology 38, 58-68.

Greenblatt CL, Baum J, Klein BY, Nachson S, Cano RJ (2004) Micrococcus luteus survival in amber. Microbial Ecology 48, 120-127. 
Grube M, Winka K (2002) Progress in understanding the evolution and classification of ichenized Ascomycetes. Mycologist 16, 67-76.

Gueidan C, Ruibal C, de Hoog S, Schneider H (2011) Rock-inhabiting fungi originated during periods of dry climate in the late Devonian and middle Triassic. Fungal Biology 115, 987-96.

Hawksworth DL (1991) The fungal dimension of biodiversity: magnitude, significance, and conservation. Mycological Research 95, 641-655.

Hawksworth DL, Kirk PM, Sutton BC, Pegler, DN (1995) Ainsworth \& Bisby's Dictionary of the Fungi. 8th edn. CAB International, Wallingford.

Hawksworth DL (2001) The magnitude of fungal diversity: the 1.5 million species estimate revisited. Mycological Research 105, 1422-1432.

Heckman, DS, Geiser, DM, Eidell BR, Stauffer RL, Kardos NL, Blair Hedges S (2001) Molecular Evidence for the Early Colonization of Land by Fungi and Plants. Science 293, 1129-1133.

Hedman MH 2010. Constraints on clade ages from fossil outgroups. Paleobiology 36, $16-31$.

Held AA (1981) Rozella and Rozellopsis: Naked endoparasitic Fungi which dress up like their hosts. The Botanical Reviews 47, 452-481.

Heled J, Drummond AJ (2012) Calibrated tree priors for relaxed phylogenetics and divergence time estimation. Systematic Biology 61, 138-149.

Helms G, Friedl T, Rambold G (2003) Phylogenetic relationships of the Physciaceae inferred from rDNA sequence data and selected phenotypic characters. Mycologia 95, 1078-1099.

Henssen A, Thor G (1994) Developmental morphology of the "Zwischengruppe", between Ascohymeniales and Ascoloculares. In: Hawksworth DL (ed) Ascomycete Systematics. Problems and Perspectives in the Nineties. Plenum Press, New York, pp $43-61$.

Henwood A (1992a) Exceptional preservation of dipteran flight muscle and the taphonomy of insects in amber. Palaios 7, 203-212.

Henwood A (1992b) Insect Taphonomy from Tertiary Amber of the Dominican Republic. PhD Thesis, University of Cambridge.

Henwood A (1993) Recent plant resins and the taphonomy of organisms in amber: A review. Modern Geology 19, 35-59.

Hibbett DS, Matheny PB (2009) The relative ages of ectomycorrhizal mushrooms and their plant hosts estimated using Bayesian relaxed molecular clock analyses. BMC Biology 7, 13.

Hibbett DS et al. (2007) A higher-level phylogenetic classification of the Fungi. Mycological Research 111, 509-547. 
Ho SYW (2007) Calibrating molecular estimates of substitution rates and divergence times in birds. Journal of Avian Biology 38, 409-414.

Hofreiter M, Serre D, Poinar HN, Kuch M, Pääbo S (2001) Ancient DNA. Nature Reviews Genetics 2, 353-359.

Hughes SJ (1978) New Zealand fungi 25. Miscellaneous species. New Zealand Journal of Botany 16, 311-370.

Inoue J, Donoghue PCJ, Yang Z (2010) The impact of the representation of fossil calibrations on Bayesian estimation of species divergence times. Systematic Biology $59,74-89$.

Jahn TL, Jahn F (1949) How to know the Protozoa. Wm.C. Brown Dubuque, Iowa

James T, Berbee ML (2011) No jacket required - new fungal lineage defies dress code: recently described zoosporic fungi lack a cell wall during trophic phase. Bioessays 34, 94-102.

James TY et al. (2006) Reconstructing the early evolution of Fungi using a six-gene phylogeny. Nature 443, 818-822.

Janzen DH (1975) Behavior of Hymenaea courbaril when its predispersal seed predator is absent. Science 189, 145-147.

Jeffroy O, Brinkmann H, Delsuc F, Philippe H (2006) Phylogenomics: the beginning of incongruence? Trends Genet 22, 225-231.

Jones MDM, Forn I, Gadelha C, Egan MJ, Bass D, Massana R \& Richards TA (2011a) Discovery of novel intermediate forms redefines the fungal tree of life. Nature 474, 200-203.

Jones MDM, Richards TA, Hawksworth DL, \& Bass D (2011b) Validation and justification of the phylum name Cryptomycota phyl. nov. IMA Fungus 2, 173-175.

Kirk PM, Cannon PF, David JC, Stalpers JA (2008) Ainsworth and Bisby's dictionary of the fungi, 10th edn. CAB International, Wallingford.

Kis-Papo T, Kirzhner V, Wasser SP, Nevo E (2003) Evolution of genomic diversity and sex extreme environments: Fungal life under hypersaline Dead Sea stress Proceedings of the National Academy of Sciences 100 14970-14975.

Koonin EV (2010) The origin and early evolution of eukaryotes in the light of phylogenomics. Genome Biology 11, 209.

Krings M, Taylor TN, Hass H, Kerp H, Dotzler N, Hermsen EJ (2007) Fungal endophytes in a 400 million-year-old land plant: infection pathways, spatial distribution, and host responses. New Phytologist 174, 648-657.

Krings M, Dotzler N, Galtier J \& Taylor TN (2009) Microfungi from the upper Visean (Mississippian) of central France: Chytridiomycota and chytrid-like remains of uncertain affinity. Review of Palaeobotany and Palynology 156, 319-328. 
Kumar TKA, Healy R, Spatafora JW, Blackwell M, McLaughlin DJ (2012) Orbilia ultrastructure, character evolution and phylogeny of Pezizomycotina. Mycologia, 104, 462-476.

Labandeira CC (2006) The four phases of plant-arthropod associations in deep time. Geologica Acta 4, 409-438.

Lambert LH, Cox T, Mitchell K, Rosselló-Mora, RA, Del Cueto C, Doge DE, Orkland P, Cano RJ (1998) Staphylococcus succinus sp. nov., isolated from Dominican amber. International Journal of Systemaic Bacteriology 48, 511-518.

Lang BF, O'Kelly C, Nerad T, Gray MW, Burger G (2002) The closest unicellular relatives of animals. Current Biology 12, 1773-1778.

Langenheim JH (1994) Higher plant terpenoids: A phytocentric overview of their ecological roles. Journal of Chemistry and Ecology 20, 1223-1280.

Langenheim JH (1995) Biology of amber-producing trees: Focus on case studies of Hymenaea and Agathis. In: Anderson KG, Crelling JC (eds), Amber, Resinite and Fossil Resins. American Chemical Society Symposium Series 617, Washington, DC, pp. 1-31.

Lara E, Moreira D, López-García P (2010) The EnvironmentalCladeLKM11and Rozella form the Deepest Branching Clade of Fungi. Protist 161 116-121.

LePage A, Currah RS, Stockey RA, Rothwell GW (1997) Fossil ectomycorrrhizae from the middle Eocene. American Journal of Botany 84, 410-412.

Liu Y, Steenkamp ET, Brinkmann H, Forget L, Philippe H and Lang F (2009) Phylogenomic analyses predict sistergroup relationship of nucleariids and Fungi and paraphyly of zygomycetes with significant support. BMC Evolutionary Biology 9, 272.

Lücking R, Lumbsch TH, Di Stéfano JF, Lizano D, Carranza J, Bernecker A, Chaves JL, Umaña L (2008) Eremithallus costaricensis (Ascomycota: Lichinomycetes: Eremithallales), a new fungal lineage with a novel lichen symbiotic lifestyle discovered in an urban relict forest in Costa Rica. Symbiosis 46, 161-170.

Lücking R, Huhndorf S, Pfister DH, Plata ER, Lumbsch TH (2009) Fungi evolved right on track. Mycologia. 10, 810-822.

Lumbsch HT, Lindemuth R, Miller A, Mangold A, Fernandez F, Huhndorf S (2005) Performance of four ribosomal DNA regions to infer higher-level phylogenetic relationships of inoperculate euascomycetes (Leotiomyceta). Molecular Phylogeny and Evolution 34, 512-524.

Lukoschek V, Keogh JS, Avise JC (2012) Evaluating fossil calibrations for dating phylogenies in light of rates of molecular evolution: a comparison of three approaches. Systematic Biology 61, 22-43.

Luttrell ES (1955) The ascostromatic Ascomycetes. Mycologia 47, 511-532. 
Lutzoni $\mathrm{F}$ et al. (2004) Assembling the fungal tree of life: progress, classification, and evolution of subcellular traits. American Journal of Botany 91, 1446-1480.

Magallón SA, Sanderson MJ (2005) Angiosperm divergence times: the effect of genes, codon positions, and time constraints. Evolution 59, 1653-1670.

Magallon SA (2010) Using fossils to break long branches in molecular dating: a comparison of relaxed clocks allied to the origin of angiosperms. Systematic Biology 59, 384-399.

Malloch DW, Pirozynski KA, Raven PH (1980) Ecological and evolutionary significance of mycorrhizal symbioses in vascular plants (a review). Proceedings of the National Academy of Science USA 77, 2113-2118.

Martínez-Delclós X, Briggs DEG, Peňalver E (2004) Taphonomy of insects in carbonates and amber. Palaeogeography Palaeoclimatology Palaeoecology 203, 1964.

Marshall CR (2008) A simple method for bracketing absolute divergence times on molecular phylogenies using multiple fossil calibration points. American Naturalist 171, 726-742.

Matheny PB, Wang Z, Binder M, Curtis JM, Lim YW, Nilsson RH, Hughes KW, Hofstetter V, Ammirati JF, Schoch CL, Langer E, Langer G, McLaughlin DJ, Wilson AW, Frøslev T, Ge ZW, Kerrigan RW, Slot JC, Yang Z-L, Baroni TJ, Fischer M, Hosaka K, Matsuura K, Seidl MT, Vauras J, Hibbett DS (2007) Contributions of rpb2 and tef1 to the phylogeny of mushroom and allies (Basidiomycota, Fungi). Molecular Phylogenetics and Evolution. 43, 430-451.

McLaughlin DJ, McLaughlin EG, Lemke PA (2001a) The Mycota. Vol. VII. Part A. Systematics and Evolution. Springer-Verlag, Berlin.

McLaughlin DJ, McLaughlin EG, Lemke PA (2001b) The Mycota. Vol. VII. PartB. Systematics and Evolution. Springer-Verlag, Berlin.

Meyer RW, Leney L (1968) Shake in coniferous wood ananatomical study. Forest Products Journal 18, 51-56.

Miądlikowska J et al. (2006) New insights into classification and evolution of the Lecanoromycetes (Pezizomycotina, Ascomycota) from phylogenetic analyses of three ribosomal RNA- and two protein-coding genes. Mycologia 98 1089-1102.

Morgenstern I, Powlowski J, Ishmael N, Darmond C, Marqueteau S, Moisan MC, Quenneville G, Tsang A, (2012) A molecular phylogeny of thermophilic fungi. Fungal Biology 116, 489-502.

Morley RJ (2000) Origin and Evolution of Tropical Rain Forests. Wiley, West Sussex, England, pp 162-166.

Moyersoen B, Becker P, Alexander IJ (2001) Are ectomycorrhizas more abundant than arbuscular mycorrhizas in tropical heath forests? New Phytologist 150, 591-599. 
Moyersoen B (2006) Pakaraimaea dipterocarpacea is ectomycorrhizal, indicating an ancient Gondwanaland origin for the ectomycorrhizal habit in Dipterocarpaceae. New. Phytol. 172, 753-762.

Nauheimer L, Metzler D, Renner SS (2012) Global history of the ancient monocot family Araceae inferred with models accounting for past continental positions and previous ranges based on fossils. New Phytologist 195, 938-50.

Nel A, Prokop J, Nel P, Grandcolas P, Huang DY, Roques P, Guilbert E, Dostál O, Szwedo J (2012) Traits and evolution of wing venation pattern in paraneopteran insects. Journal of Morphology 273, 480-506.

Newbery DM, Alexander IJ, Thomas DW, Gartlan JS (1988) Ectomycorrhizal rainforest legumes and soil phosphorus in Korup National Park, Cameroon. New Phytologist 109, 433-450.

Ohm RA et al. (2012) Diverse Lifestyles and Strategies of Plant Pathogenesis Encoded in the Genomes of Eighteen Dothideomycetes Fungi. PLOS 8 e1003037.

Padovan ACB, Sanson GFO, Brunstein A, Briones MRS (2005) Fungi Evolution Revisited: Application of the Penalized Likelihood Method to a Bayesian Fungal Phylogeny Provides a New Perspective on Phylogenetic Relationships and Divergence Dates of Ascomycota Groups. Journal of Molecular Evolution 60, 726735.

Parham JF, Donoghue PCJ, Bell CJ, Calway TD, Head JJ, Holroyd PA, Inoue JG, Irmis RB, Joyce WG, Ksepka DT, Patane JSL, Smith ND, Tarver JE, van Tuinen M, Yang ZH, Angielczyk KD, Greenwood JM, Hipsley CA, Jacobs L, Makovicky PJ, Mueller J, Smith KT, Theodor JM, Warnock RM, Benton MJ (2012) Best Practices for justifying fossil calibrations. Systematic Biology 61, 346-359.

Peñalver E, Delclós X, Soriano C (2007) A new rich amber outcrop with palaeobiological inclusions in the Lower Cretaceous of Spain. Cretaceous Research 28, 791-802.

Perrichot V, Girard V (2009) A unique piece of amber and the complexity of ancient forest ecosystems. Palois. 24, 137-139.

Philippe H, Brinkmann H, Lavrov DV, Littlewood DTJ, Manuel M, Wörheide G, Baurain D (2011) Resolving Difficult Phylogenetic Questions: Why More Sequences Are Not Enough. PLoS Biol 9, e1000602.

Pirozynski KA, Malloch DW (1975) The origin of land plants: a matter of mycotrophism. Biosystems 6, 153-64.

Pitt JI (1994) The current role of Aspergillus and Penicillium in human and animal health. Journal of Medical and Veterinary Mycology 32, 17-32.

Poinar GO Jr, Hess R (1982) Ultrastructure of 40-millionyear-old insect tissue. Science 215, 1241-1242. 
Poinar GO, Poinar R (1994) The quest for life in amber. Addison-Wesley Publishing Company, Reading, MA.

Poinar GO Jr, Peterson EB, Platt JL (2000) Fossil Parmelia in New World Amber. Lichenologist 32, 263-269.

Posada D (2008) jModelTest: Phylogenetic Model Averaging. Molecular Biology and Evolution 25, 1253-1256.

Praham et al. (2012) Best Practices for Justifying Fossil Calibrations. Systematic Biolology 61, 346-359.

Prieto A, Leal JA, Bernabé M, Hawksworth DL (2008) A polysaccharide from Lichina pygmaea and L. confinis supports the recognition of Lichinomycetes, Mycological Research 112, 381-388.

Pyron RA (2010) A likelihood method for assessing molecular divergence time estimates and the placement of fossil calibrations. Systematic Biology 59, 185-195.

Raja HA, Stchigel AM, Miller AN, Crane JL, Shearer CA (2007) Hyphomycetes from the Great Smoky Mountains National Park, including three new species. Fungal Diversity 26, 271-286.

Rambold G, Friedl T, Beck A (1998) Photobionts in lichens: possible indicators of phylogenetic relationships? Bryologist 101, 392-397.

Ramírez SR, Gravendeel B, Singer BR, Marshall CR, Pierce NE (2007) Dating the origin of the Orchidaceae from a fossil orchid with its pollinator. Nature 448, 10421045.

Ranghoo VM, Hyde KD (1998) Ascomycetes from freshwater habitats: Ascolacicola aquatica gen. et sp. nov. and a new species of Ascotaiwania from wood submerged in a reservoir in Hong Kong. Mycologia 90, 1055-1062.

Ranghoo VM, Goh TK, Hyde KD (1999) New observations on Monotosporella rhizoidea. Mycoscience 40, 377-382.

Rao V, de Hoog GS (1986) New or critical Hyphomycetes from India. Studies in Mycology 28, 1-84.

Redecker D, Kodner R, Graham LE (2000) Glomalean fungi from the Ordovician. Science 289, 1920-1921.

Reeb V, Lutzoni F, Roux C (2004) Multilocus phylogenetic circumscription of the lichen-forming fungi family Acarosporaceae and its position within the Ascomycota. Molecular Phylogeny and Evolution 32, 1036-1060.

Remy W, Taylor TN, Hass H, Kerp H (1994) Four hundred-million-year old vesicular arbuscular mycorrhizae. Proceedings of the National Academy of Science USA 91, 11841-11843.

Rikkinen J (1999) Two new species of resinicolous Chaenothecopsis (Mycocaliciaceae) from western North America. Bryologist 102, 366-369. 
Rikkinen J (2003a) Chaenothecopsis nigripunctata, a remarkable new species of resinicolous Mycocaliciaceae from western North America. Mycologia 95, 98-103.

Rikkinen J (2003b) Calicioid lichens and fungi in the forests and woodlands of western Oregon. Acta Botanica Fennica 175, 1-41.

Rikkinen J, Poinar GO Jr (2000) A new species of resinicolous Chaenothecopsis (Mycocaliciaceae, Ascomycota) from 20 million year old Bitterfeld amber, with remarks on the biology of resinicolous fungi. Mycological Research 104, 7-15.

Rikkinen J, Poinar GO Jr (2002) Fossilised Anzia (Lecanorales, lichen-forming Ascomycota) from European Tertiary amber Mycoogical. Reseach 106, 984-990.

Rikkinen J, Poinar GO Jr (2008) A new species of Phyllopsora (Lecanorales, lichenforming Ascomycota) from Dominican amber, with remarks on the fossil history of lichens. Journal of Experimental Botany 59, 1007-1011.

Rikkinen J, Dörfelt H, Schmidt AR, Wunderlich, J (2003) Sooty moulds from European Tertiary amber, with notes on the systematic position of Rosaria (Cyanobacteria). Mycological Research 107, 251-256.

Ronquist F, Huelsenbeck JP (2003) Bayesian phylogenetic inference under mixed models. Bioinformatics 19, 1572-1574.

Rossi W, Kotrba M, Triebel D (2005) A new species of Stigmatomyces from Baltic amber, the first fossil record of Laboulbeniomycetes. Mycological Research 109, 271-274.

Rust J, et al. (2010) Biogeographic and evolutionary implications of a diverse paleobiota in amber from the Early Eocene of India. Proceedings of the National Academy of Sciences 107, 18360-18365.

Sadowski E-M, Beimforde C, Gube M, Rikkinen J, Singh H, Seyfullah LJ, Heinrichs J, Nascimbene PC, Reitner J, Schmidt AR (2012) The anamorphic genus Monotosporella (Ascomycota) from Eocene amber and from modern Agathis resin. Fungal Biology 116, 1099-1110.

Samuels GJ, Blackwell M (2001) Pyrenomycetes-fungi with perithecia. In: McLaughlin DJ McLaughlin EG, Lemke PA (eds) The Mycota VII Part A. Berlin, Heidelberg: Springer Verlag. pp 221-255.

Sanderson MJ (2002) Estimating absolute rates of molecular evolution and divergence times: a penalized likelihood approach. Molecular Biology and Evolution 19, 101109.

Sanderson MJ (2003) Molecular data from 27 proteins do not support a Cambrian origin of land plants. American Journal of Botany 90, 954-956.

Sauquet H, Ho SYW, Gandolfo MA, Jordan GJ, Wilf P, Cantrill DJ, Bayly MJ, Bromham L, Brown GK, Carpenter RJ, Lee DM, Murphy DJ, Sniderman JMK, Udovicic F (2012) Testing the impact of calibration on molecular divergence times 
using a fossil-rich group: the case of Nothofagus (Fagales). Systematic Biology 61, 289-313.

Schmidt AR, Schäfer U (2005) Leptotrichites resinatus new genus and species, a fossil sheathed bacterium in alpine Cretaceous amber. Journal of Paleontology 79, 184-193

Schmidt AR, Schönborn W, Schäfer U (2004) Diverse fossil amoebae in German Mesozoic amber. Palaeontology 47, 185-197.

Schmidt AR, Ragazzi E, Coppellotti O, Roghi G (2006) A microworld in Triassic amber. Nature 444835.

Schmidt AR, Perrichot V, Svojtka M, Anderson KB, Belete KH, Bussert R, Dörfelt H, Jancke S, Mohr S, Mohrmann E, Nascimbene PC, Nel A, Nel P, Ragazzi E, Roghi G, E. Saupe E, Schmidt K, Schneider H, Selden PA, Vávra N (2010a) Cretaceous African life captured in amber. Proceedings of the National Academy of Sciences USA 107, 7329-7334.

Schmidt A.R., Dörfelt, H., Struwe, S., Perrichot, V. (2010b). Evidence for fungivory in Cretaceous amber forests from Gondwana and Laurasia. Palaeontographica. 283, 157-173.

Schmidt AR, Jancke S, Lindquist EE, Ragazzi E, Roghi G, Nascimbene PC, Schmidt K, Wappler T, Grimaldi DA (2012) Arthropods in amber from the Triassic Period. Proceedings of the National Academy of Sciences USA 109, 14796-14801.

Schmidt AR, Beimforde C, Seyfullah LJ, Wege SE, Dörfelt H, Girard V, Grabenhorst H, Gube M, Heinrichs J, Nel A, Nel P, Perrichot V, Reitner J, Rikkinen J (in review). Amber fossils of sooty moulds. Review of Palaeobotany and Palynology.

Schneider H, Schuettpelz E, Pryer KM, Cranfill R, Magallón S, Lupia R (2004) Ferns diversified in the shadow of angiosperms. Nature 428, 553-557.

Schoch CL, Shoemaker RA, Seifert KA, Hambleton S, Spatafora JW, Crous PW (2006) A multigene phylogeny of the Dothideomycetes using four nuclear loci Mycologia, 98, 1041-1052.

Schoch CL et al. (2009). The Ascomycota Tree of Life: A Phylum-wide Phylogeny Clarifies the Origin and Evolution of Fundamental Reproductive and Ecological Traits. Systematic Biology (2009) 58, 224-239.

Schönborn W, Dörfelt H, Foissner W, Krienitz L, Schäfer U (1999) A fossilized microcenosis in Triassic amber. Journal of Eukaryotic Microbiology 46 571-584.

Seifert K, Morgan-Jones G, Gams W, Kendrick B (2011) The genera of the Hyphomycetes. CBS-KNAW Fungal Biodiversity Centre, Utrecht.

Simon J, Bousquet L, Lévesque RC, Lalonde M (1993) Origin and diversification of endomycorrhizael fungi and coincidence with vascular land plants. Nature 363 67-69

Sivichai S, Hywel-Jones N, Jones EBG (1998) Lignicolous freshwater Ascomycota from Thailand: 1. Ascotaiwania sawada and its anamorph state Monotosporella. Mycoscience 39, 307-311. 
Sparrow FK, Paterson RA, Johns RM (1965) Additionstothe phycomycete flora of the Douglas Lake region. V. New or interesting fungi. Papers of the Michigan Academy of Science 50, 115-123.

Spatafora JW et al. (2006) A five-gene phylogenetic analysis of the Pezizomycotina. Mycologia 98, 1020-1030.

Stankiewicz BA, Poinar HN, Briggs DEG, Evershed RP, Poinar GO Jr (1998) Chemical preservation of plants and insects in natural resins. Philosophical Transactions of the Royal Society of London, Series B 265, 641-647.

Steenkamp ET, Wright, J and Baldauf SL (2006) The Protistan Origins of Animals and Fungi. Molecular Biologie and Evolution 23, 93-106.

Sterflinger K, Hoog GS, Haase G (1999) Phylogeny and ecology of meristematic ascomycetes. Studies in Mycology 43, 5-22.

Sugiyama J, Hosaka K, Suh S-O (2006) Early diverging Ascomycota: phylogenetic divergence and related evolutionary enigmas. Mycologia 98 996-1005.

Szwedo J, Nel A (2011) The oldest aphid insect from the Middle Triassic of the Vosges, France. Acta Palaeontologica Polonica 56, 757-766.

Taylor JW, Berbee ML (2006) Dating divergences in the Fungal Tree of Life: review and new analyses. Mycologia 98, 838-84.

Taylor TN, Galtier J, Axsmith BJ (1994) Fungi from the Lower Carboniferous of central France. Review of Palaeobotany and Palynology 83, 253-260.

Taylor TN, Hass H, Kerp H, Krings M, Hanlin RT (2005) Perithecial ascomycetes from the 400 million year old Rhynie chert: an example of ancestral polymorphism. Mycologia 97, 269-285.

Thell, A., Crespo A., Divakar, P.K., Kärnefelt, I., Leavitt, S. D., Lumbsch, T.H., Seaward, M.R.D., 2012. A review of the lichen family Parmeliaceae - history, phylogeny and current taxonomy. Nord. J. Bot. 30, 641-664.

Tibell L (1984) A reappraisal of the taxonomy of Caliciales. Nova Hedwigia Beiheft 79, $597-714$.

Tibell L (2001) Photobiont Association and Molecular Phylogeny of the Lichen Genus Chaenotheca. The Bryologist 104, 191-198.

Tibell L (2003) Tholurna dissimilis and generic delimitations in Caliciaceae inferred from nuclear ITS and LSU rDNA phylogenies (Lecanorales, lichenized ascomycetes). Mycological Research 107, 1403-1418.

Tibell L, Titov A (1995) Species of Chaenothecopsis and Mycocalicium (Caliciales) on exudate. The Bryologist 98, 550-560.

Tibell L, Koffmann A (2002) Chaenotheca nitidula, A New Species of Calicioid Lichen from Northeastern North America. The Bryologist 105 353-357.

True RP, Snow, AG (1949) Gum flow from turpentine pines inoculated with the pitchcanker Fusarium. Journal of Forestry 47, 894-899. 
Tsui CKM, Goh TK, Hyde KD, Hodgkiss IJ (2001) New species or records of Cacumisporium, Helicosporium, Monotosporella and Bahusutrabeeja on submerged wood in Hong Kong streams. Mycologia 93, 389-397.

Tuovila H, Cobbinah JR, Rikkinen J (2011a) Chaenothecopsis khayensis, a new resinicolous calicioid fungus on African mahogany. Mycologia 103 610-615.

Tuovila H, Larsson P, Rikkinen J (2011b) Three resinicolous North American species of Mycocaliciales in Europe with a re-evaluation of Chaenothecopsis oregana Rikkinen. Karstenia 51, 37-49.

Tuovila H, Schmidt AR, Beimforde C, Dörfelt H, Grabenhorst H, Rikkinen J (2013) Stuck in time - a new Chaenothecopsis species with proliferating ascomata from Cunninghamia resin and its fossil ancestors in European amber. Fungal Diversity 58, 199-213.

Vakili NG (1989) Gonatobotrys simplex and its teleomorph, Melanospora damnosa. Mycological Research 93 67-74.

van der Ham RWJM, Dortangs RW (2005) Structurally preserved ascomycetous fungi from the Maastrichtian type area (NE Belgium). Review of Palaeobotany and Palynology 136, 48- 62.

Voelkerding KV, Shale AD, Durtschi JD (2005) Next-Generation Sequencing: From Basic Research to Diagnostics. Clinical Chemistry 55, 641-658.

Wang B, Yeun LH, Xue J-Y, Liu Y, Ané J-M, Qiu Y-L (2010) Presence of three mycorrhizal genes in the common ancestor of land plants suggests a key role of mycorrhizas in the colonization of land by plants. New Phytologist 186 514-525.

Wang H, Xu Z, Gao L, Hao B (2009) A fungal phylogeny based on 82 complete genomes using the composition vector method. BMC Evolutionary Biology 9195.

Wang Z, Schoch CL, Johnston PR, Spatafora JW, Hibbett DS (2006) Evolution of helotialean fungi (Leotiomycetes, Pezizomycotina): a nuclear rDNA phylogeny. Molecular Phylogenetic and Evolution 41, 295-312.

Webster J, Weber R (2009) Introduction to the fungi. Cambridge University Press, Cambridge.

Wedin M, Baloch E, Grube M (2002) Parsimony analyses of mtSSU and nITS rDNA sequences reveal the natural relationships of the lichen families Physciaceae and Caliciaceae. Taxon 51, 655-60.

Wedin M, Döring H, Gilenstam G (2004) Saprotrophy and lichenization as option for the same fungal species on different substrata: environmental plasticity and fungal lifestyles in the Stictis-Conotrema complex. New Phytologist 164, 459-465.

Weir A, Blackwell M (2001) Molecular data support the Laboulbeniales as a separate class of Ascomycota, Laboulbeniomycetes. Mycoogical Research 105 1182-1190.

Whittaker RH (1959) On the broad classification of organisms. The Quarterly review of biology 34, 210-26. 
Wilkinson RD, Steiper ME, Soligo C, Martin RD, Yang ZH, Tavaré S (2011) Dating primate divergences through an integrated analysis of palaeontological and molecular data. Systematic Biology 60, 16-31.

Wikström N, Savolainen V, Chase MW (2010) Evolution of the Angiosperms: calibrating the family tree. Proceedings of the Royal society Series B 268, 22112220 .

Willerslev E, Hansen AJ, Poinar HN (2004) Isolation of nucleic acids and cultures from fossil ice and permafrost. Trends in Ecology and Evolution 19, 141-147.

Willerslev E, Cooper A (2005) Ancient DNA. Proceedings Royal Society London, Series B Biological Science 272, 3-16.

Woese CR (1987) Bacterial Evolution. Microbiological Reviews 51, 221-271.

Yang Y, Yang E, An Z, Liu Y (2007) Evolution of nematode-trapping cells of predatory fungi of the Orbiliaceae based on evidence from rRNA-encodin DNA and multiprotein sequences. Proceedings of the National Academy of Science USA 104, 8379-8384.

Yanna; Hyde KD (2002) New saprobic fungi on fronds of palms from northern Queensland, Australia. Australian Systematic Botany 15, 755-764.

Zhang N, Castlebury LA, Miller AN, Huhndorf SH, Schoch CL, Seifert KA, Rossman AY, Rogers JD, Volkmann-Kohlmeyer B, Sung G-H (2006) An overview of the systematics of the Sordariomycetes based on a four-gene phylogeny. Mycologia 98, 1076-1087. 
Appendices 
Appendix 1

\section{Appendix 1}

Beimforde C, Schmidt AR (2011) Microbes in resinous habitats: a compilation from modern and fossil resins. In: Reitner J, Queric N-V, Arp G (eds), Advances in Stromatlite Geobiology. Lecture Notes in Earth Sciences, 131, 391-407. 


\title{
Microbes in resinous habitats: a compilation from modern and fossil resins
}

\author{
Christina Beimforde and Alexander R. Schmidt \\ Courant Research Centre Geobiology, Georg-August-Universität Göttingen, \\ Goldschmidtstr. 3, 37077 Göttingen, Germany \\ Corresponding author: Alexander Schmidt (alexander.schmidt@geo.uni-goettingen.de)
}

\begin{abstract}
Interactions of microorganisms with fresh and fossil resin may be very diverse and are sometimes poorly understood. In this study, we illustrate and discuss various associations of microbes and resins. We examined microorganisms from inside and at the surface of various modern and fossil resins and found microorganisms that (1) were enclosed by resin, (2) showed patterns of growth into the resin, and (3) colonized the resin surfaces. Various limnetic and terrestrial microorganisms were found entirely engulfed in resins. Furthermore, we observed modern fungal and prokaryotic filaments growing into liquid resins until solidification occurred. Correspondingly many amber pieces contain fossil filamentous bacteria or fungi which grew into the formerly liquid resin. Most likely they used the liquid resin as a temporary habitat and became well preserved when the resin solidified. Apart from these fossils, various living bacteria, fungi and algae were found at the surface and in cracks of amber pieces. Recent microbial colonization of amber pieces may accelerate processes of degradation of amber.
\end{abstract}

Key words: amber, fossil bacteria, fossil fungi, resinicolous microorganisms 


\section{Introduction}

Amber can be considered as a window into the past allowing insights into the palaeoecology of Mesozoic and Cenozoic woodlands. Insects, spiders, fragments of higher plants and even small vertebrates were trapped by resins of conifers and angiosperms of the ancient "amber forests". Apart from these macroinclusions, amber may contain diverse and well-preserved fossil microorganisms (e.g., Waggoner 1994, Schönborn et al. 1999, Schmidt et al. 2006). Most often they are representatives of limnetic or humid microhabitats of the forest floor (Girard et al. 2009b). Although microorganisms associated with amber are known for a long time (e. g. Berkeley 1848, Caspary \& Klebs 1907, Galippe 1920, Blunck 1929) extensive studies were not done until the end of the 1980s (e. g. Ting \& Nissenbaum 1986, Waggoner 1993, 1994, 1996). Currently, continuous research on microinclusions is done at several institutions (e.g., Schmidt et al. 2006, Rikkinen 2000, Girard et al. 2009b). Various fossil microorganisms such as bacteria, cyanobacteria, fungi, algae, protozoans and micrometazoans can be found associated in single amber pieces (Schmidt 2006; Girard et al. 2008b). Amber preserved organisms from forest habitats where fossilizationprocesses rarely happened. Furthermore, besides of chert, amber is the only source of well-preserved fossil soft-bodied microorganisms. Because of the excellent preservation even of cell organelles, a morphological characterization and a direct comparison to determinable recent organisms is often possible (Dörfelt \& Schäfer 2000; Dörfelt \& Schmidt 2007, Schmidt et al. 2006). The reconstruction of microbial life cycles and interactions of plants and microorganisms of Mesozoic and Cenozoic ecosystems is of special interest in examining amber microinclusions. Furthermore, amber inclusions may help to trace the evolutionary history of groups of organisms that are otherwise rarely or never preserved.

Until now, only little research has been done about recent microorganisms that are associated with fresh resin and amber. Resinicolous fungi are found on resins and other exudates of vascular plants (Tibell \& Titov 1995, Rikkinen 1999, 2003) and also bacteria can be observed growing into liquid resin (Schmidt \& Dilcher 2007, Schmidt \& Schäfer, 2005). The first researcher who noticed modern microorganisms from fossil resin samples was Galippe (1920). He observed bacteria on Cretaceous and Cenozoic amber samples from various localities. Recently, a study by Girard et al. (2008a) emphasized the occurrence of recent bacteria and diatoms at surfaces and in fissures of mid-Cretaceous amber samples that were found at the sea shore and in freshwater lakes of southwestern France.

In the 1990's, several papers dealt with DNA enclosed in amber and from amberpreserved insect and plant inclusions (e.g., Cano et al. 1994, Poinar \& Poinar 1994, 
Lambert et al. 1998, Greenblatt et al. 1999). However, critical reinvestigations suggest that the DNA obtained in these studies was modern contamination. Because even the amplification of DNA from copal failed, Austin et al. (1997) concluded that resin is not predestined for preservation of complex molecules such as DNA although morphological structures are recorded very well. Greenblatt et al. (2004) demonstrated that it is difficult or almost impossible to get the amber free of modern DNA and RNA since bacteria, fungi and other microbes remain in fissures even after surface sterilization by ultrasonic cleaning, $\mathrm{H} 2 \mathrm{O} 2$ and ethanol as described by Lambert et al. (1998). Greenblatt et al. (1999, 2004) isolated putative fossil microorganisms from different ambers but characterisation of the supposed microfossils showed that they were actually much younger than the amber itself. Thereupon they suggested that the microorganisms exist as contaminants in amber cracks. The estimation of the exact date of these supposed microfossils seems to be impossible. Since non-degraded modern molecules are always preferred during the polymerase chain reaction, an amplification of fragments of ancient DNA is highly unlikely and today it is widely assumed that DNA does generally not persist more than thousands of years as amplifiable molecules (Hofreiter et al. 2001, Willerslev et al. 2004, Willerslev \& Cooper 2005).

Investigating amber one has to consider that amber is an organic substance and thus potentially represents an attractive substrate by itself. Because of their habitat specificity, it has been suggested that resinicolous fungi use liquid resin as sole nutrient source. Thereby the fungal mycelium penetrates into upper regions of liquid resins (Tibell \& Titov 1995, Rikkinen et al. 2000, 2003). Greenblatt et al. (2004) postulate, that bacteria colonize small cracks of amber and possibly use the amber as a nutrient source.

These previous studies indicate that interactions of microorganisms with fresh and fossil resin may be very diverse and are sometimes poorly understood. We therefore examined microorganisms from inside and at the surface of various modern and fossil resins. In both, modern and fossil resins, we found microbes that (1) were enclosed by resin, (2) showed patterns of growth into the resin, and (3) colonized the resin surfaces. It is the intent of this study to illustrate and to discuss these various associations of microbes and resins. 


\section{Material and methods}

We investigated modern and fossil resins of various botanical sources that were colonized by microbial communities before and after solidification of the resin. The pieces of amber were ground and polished manually with a series of wet silicon carbide papers (grit from 600 to 4000, firm Struers, Germany) to minimize light scattering for the investigation of the inclusions. The samples of modern and fossil resins and fragments thereof were examined under incident-light (Carl Zeiss Stemi 2000) and transmitted light microscopes (Carl Zeiss AxioScope A1 with long-distance objectives) equipped with Canon 450D digital cameras and under a scanning electron microscope (Carl Zeiss LEO 1530).

In laboratory experiments, fresh resin of Cycas revoluta and Pinus strobus was placed on a microscopic slide, coated with a cover slip and stored under humid conditions in a Petri dish for two weeks. Growth of microbes was observed daily.

For sequencing, electrophoresis was carried out on an ABI Prism 3100 Genetic Analyser. Sequences were assembled and edited in BioEdit version 7.0.8 (www.mbio.ncsu.edu/BioEdit/bioedit.html) and ARB version 4.0 (www.arb-home.de).

\subsection{Modern resin investigated}

Resin of Agathis lanceolata Lindley ex Warburg and Agathis ovata (Moore) Warburg (Araucariaceae). The resin samples derive from southeastern New Caledonia and were collected by A.R.S. in 2005. These Agathis species have a natural massive resin production. Root-resin of $A$. lanceolata was found solidified at the forest floor. Solidified resin of $A$. ovata was collected at the base of the tree trunks. The samples are housed at the Geoscientific Museum of the University of Göttingen (GZG.BST 14975 to GZG.BST 14977).

Resin of Pinus elliottii Engelmann (Pinaceae). The resin samples originate from 'Dilcher's swamp forest', a swamp in a warm-temperate mixed forest east of the city of Gainesville in north central Florida. The resin samples were collected by A.R.S. and David L. Dilcher in 2006 in liquid and solid stage (for methods, see Schmidt \& Dilcher 2007). The sample is housed at the Geoscientific Museum of the University of Göttingen (GZG.BST 14974).

Resin of Prunus avium L. (Rosaceae). Resin was collected at a tree trunk near the city of Jena in central Germany. The sample is housed at the Geoscientific Museum of the University of Göttingen (GZG.BST 14973). 
Resin of Cycas revoluta Thunberg (Cycadaceae) and Pinus strobus L. (Pinaceae). Resin of potted plants was used for laboratory studies on the growth of bacteria, cyanobacteria and fungi in liquid resin.

\subsection{Fossil resin investigated}

Cretaceous amber from Golling (Salzburg, Austria). Amber from this famous locality is probably Hauterivian in age (for review, see Vávra 2005). Samples were kindly provided by Johann Peschl (Laufen) and are housed in the Museum für Naturkunde Berlin (MB. Pb 2009/344).

Cretaceous amber from Myanmar (Burma). Both, biostratigraphic data obtained from the amber-bearing sediment and the amber inclusions indicate a mid-Cretaceous age of the amber (Grimaldi et al., 2002; Cognato \& Grimaldi, 2009). Based on a recent re-investigation of the amber locality, Cruickshank \& Ko (2003) suggest an Upper Albian age of the sediment. The samples are housed in the British Natural History Museum in London (BNHM In 20206).

Cretaceous amber from Santander (Spain). This Upper Albian amber was found north of the village of Ubiarco that is situated about $20 \mathrm{~km}$ west of Santander (Wilmsen 1997). The samples were kindly provided by Markus Wilmsen (Würzburg) and are housed in the Museum für Naturkunde Berlin (MB. Pb 2009/345 and MB. Pb 2009/346) and in the Geoscientific Museum of the University of Göttingen (GZG.BST 14973).

Cretaceous amber from Kuji (Japan). This amber originates from the Late Cretaceous Tamagawa Formation near the city of Kuji and is probably Coniacian in age (see Krumbiegel \& Krumbiegel 2005). The samples are housed in the British Natural History Museum in London (BNHM V.65206).

Cretaceous amber from the Cedar Lake (Canada). Cedar Lake amber is considered to be Upper Cretaceous (probably Campanian) in age (see McKellar et al. 2008). The samples were kindly provided by Ulf-Christian Bauer (Schliersee) and are housed in the Museum für Naturkunde Berlin (MB. Pb 2009/347).

Eocene Baltic amber from Russia. The pieces of Baltic amber were found in the Kaliningrad (Königsberg) area on the eastern coast of the Baltic Sea (western Russia). The sediments containing the majority of Baltic amber in the Kaliningrad area are 47-38 million years old (Ritzkowski 1999, Standke 2008). One amber piece investigated was 
kindly loaned from Wolfgang Weitschat (Hamburg; collection number 1805 of the amber collection of the Institute of Geology and Palaeontology of the University of Hamburg, Germany). Eocene Baltic amber of the collection of the Geoscientific Museum of the University of Göttingen was also investigated (GZG.HST 19 and GZG.HST 21). These samples are part of the historic Blumenbach collection that was collected by Johann Friedrich Blumenbach in (1752-1840). These samples have been stored in the Göttingen collection for more than 200 years. During the whole storage period the amber was kept in the dark and exposed to low air humidity. Since 40 years the ambient conditions of the storage-room are kept at a constant level of 40-60\% air humidity and $22^{\circ} \mathrm{C}$.

\section{Results and discussion}

Our studies revealed that microorganisms can be associated with plant resins in three different ways since (1) enclosure by resin, (2) growth into resins and (3) colonization of resin surfaces and fissures may take place.

\subsection{Microorganisms enclosed by resin}

Various limnetic and terrestrial microorganisms were found engulfed, i.e., entirely embedded in resins. Among others, representatives of conjugatophytes (Fig. 1A) and testate amoeba (testate lobose amoebae, order Arcellinida, Fig. 1B-C) were found inside resin flows of Pinus elliottii from a Florida swamp forest. Single celled limnetic organisms became enclosed, when resin flowed down the tree trunks and reached the humid forest floor. Some of these inclusions exhibit an excellent preservation of detailed structures such as chloroplasts (Fig. 1A). Schmidt \& Dilcher (2007) found all major groups of limnic microorganisms of the swamp water embedded in resin of Pinus elliottii, a species that exhibits a massive natural resin production. Limnetic-terrestrial microorganisms have also repeatedly been reported from Cretaceous ambers. Aquatic bacteria, microalgae, conjugatophytes, ciliates and testate amoebae described from the Cenomanian Schliersee amber from the Bavarian Alps are examples hereof (see Schönborn et al. 1999, Dörfelt \& Schäfer 2000, Schmidt et al. 2004). 

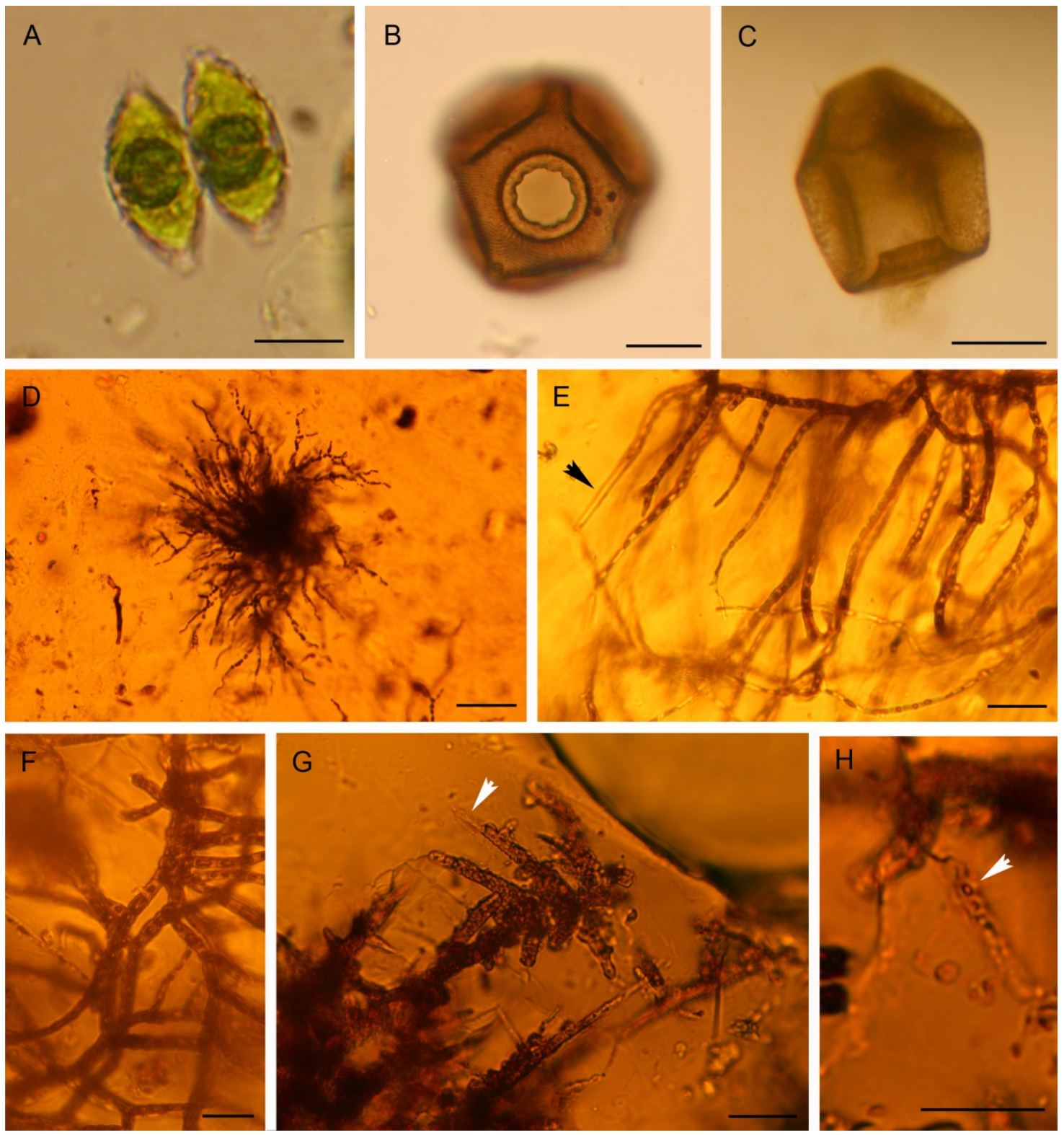

Figure 1. Light-microscopical images of modern and fossil microorganisms that became engulfed by resin: A Conjugatophyte of the genus Cosmarium enclosed in modern resin from Pinus elliottii. B-C Testate amoeba of the genus Arcella in ventral $\mathbf{B}$ and lateral $\mathbf{C}$ view inside $P$. elliottii resin. D-F Epiphytic cyanobacteria enclosed in modern resin of Prunus avium (GZG.BST 14973). The filaments continued to grow for a short time after embedding. The arrow shows a narrow filaments in which cross walls are absent. G-H Fossil cyanobacteria in Upper Cretaceous amber from Canada (MB.Pb.2009/347). The arrow in (C) indicates a narrow filament without cross walls; the arrow in H shows a regular filament. Scale bars represent $30 \mu \mathrm{m}$ in A-C and E-H, and $200 \mu \mathrm{m}$ in D. 

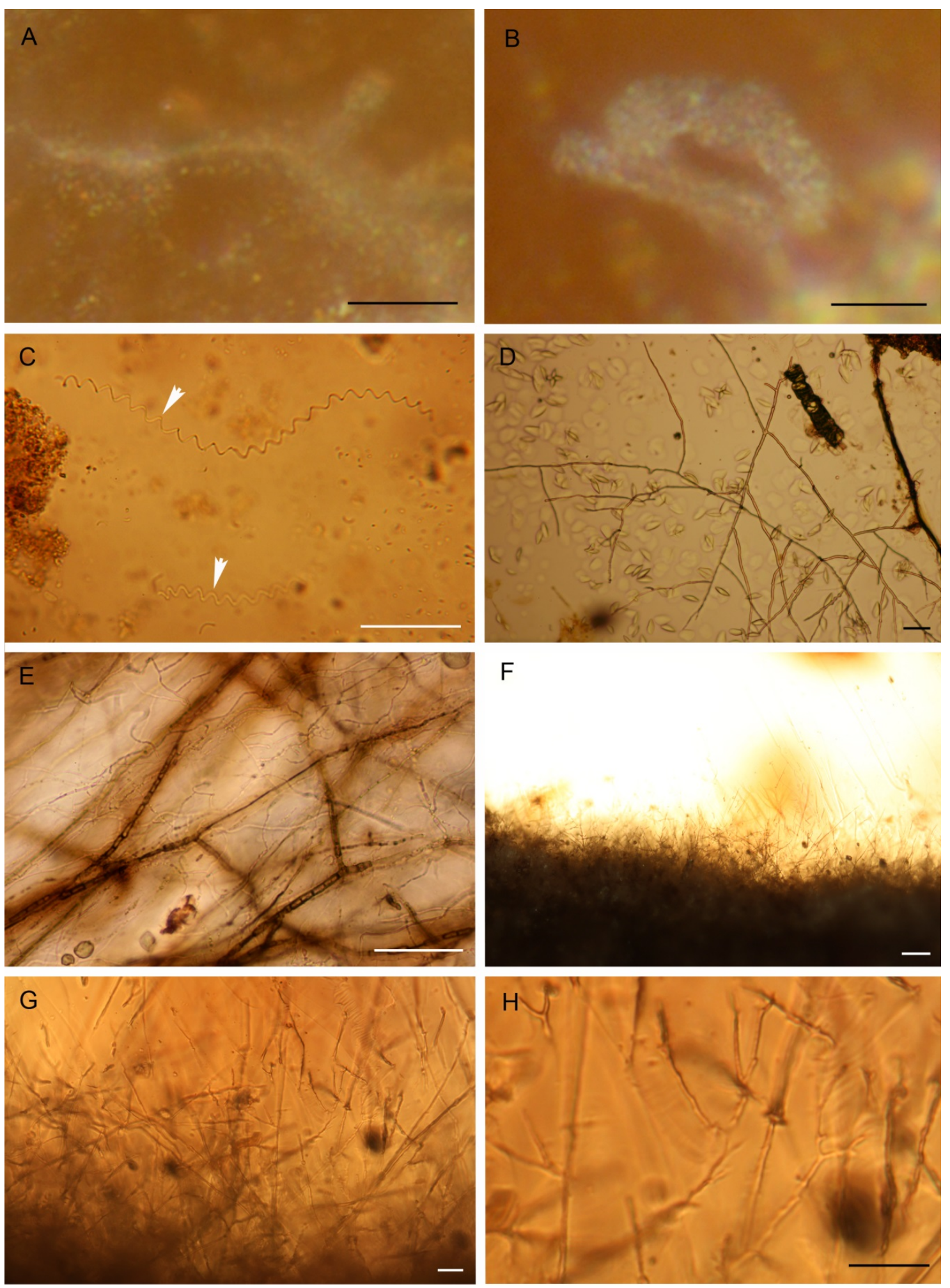

Figure 2. Light-microscopical images of modern microorganisms that grew on and into liquid resin: A-B Leptothrix-like sheated bacteria inside modern resin of Pinus elliottii (GZG.BST 14974). C Spiral prokaryotic filaments growing in resin of Pinus elliottii. D Fungal hyphae growing in resin of Pinus elliottii. E Fungal hyphae growing into liquid resin of Cycas revoluta. F-H Resinicolous fungi grown into modern resin of Agathis lanceolata in New Caledonia (GZG.BST 14975). Scale bars represent $10 \mu \mathrm{m}$ in $\mathrm{A}-\mathrm{B}, 50 \mu \mathrm{m}$ in $\mathrm{C}-\mathrm{E}, 100 \mu \mathrm{m}$ in $\mathrm{F}$, and $20 \mu \mathrm{m}$ in $\mathrm{G}-\mathrm{H}$. 
Cyanobacteria are rarely enclosed in fossil resins. We found modern filamentous cyanobacteria inside resin at the trunk of a cherry tree (Prunus avium, Fig. 1D-F). After becoming entirely enclosed by the fresh resin, further growth of the filaments took place for a short time. During this limited growth, narrow filaments were produced in which cross walls were often absent. We discovered similar narrow filaments without cross walls in cyanobacterial mats inside Upper Cretaceous amber from the Cedar Lake in Canada (Fig. $1 \mathrm{G}-\mathrm{H}$ ). Therefore, we interpret these fossil cyanobacteria to be alive during embedding and a couple of hours to days afterwards in the liquid resin.

However, generally those entirely embedded organisms died off immediately after embedding and correspond to the classic term of inclusions since they do not touch the resin surface at all.

\subsection{Microorganisms growing on and into the liquid resin}

We found many examples of modern and fossil fungal hyphae and filamentous bacteria that grew from the surface into the resin bodies until solidification occurred. Despite being preserved inside amber and modern resin, these inclusions do not correspond to the typical criteria of inclusions because they touch the surface at least at one point.

Sheathed bacteria occurred sometimes in fresh resin of Pinus elliottii that flowed into the ponds of a Florida swamp forest. Their sheaths are about $10 \mu \mathrm{m}$ in diameter and exhibit a central lumen of about $1 \mu \mathrm{m}$ diameter. Cell chains could sometimes not be identified inside the lumen. As in modern Leptothrix specimens, the observed sheaths are hyaline, slightly granulated and contain minute gas bubbles which might indicate metabolic activity after embedding in the resin (Fig. 2A-B). Spiral prokaryotic filaments and branched fungal hyphae were regularly found in P. elliottii resin that had contact to the swamp water (Fig. 2C-D).

Correspondingly, many Cretaceous amber pieces are interspersed with fossil bacterial filaments. We found filaments that are composed of rod-shaped cells (Fig. 3A-B), but mostly sheathed branched cell chains or empty sheaths that morphologically closely resemble modern representatives of the genus Leptothrix occurred in the ambers (Figs. $3 \mathrm{C}-\mathrm{I})$. The random orientation of the sheathed filaments and the absence of broken parts thereof suggest that these filaments grew from the surface to the inner parts of the formerly liquid resin bodies. In many cases, the densely arranged fossil bacterial filaments even cause opacity of the outer parts of the resin pieces. Sometimes, cell chains are visible (Fig. 3F). The sheaths of ca $10 \mu \mathrm{m}$ diameter are mostly hyaline and often contain gas bubbles (Fig. 3I). Under the scanning electron microscope, empty tubes were visible at the former location of the cell chains and bubble-shaped holes are frequently visible inside the resin-preserved sheaths (Fig. 4A-B). Sometimes, possible remnants of the former cells were seen attached to the inner face of the tubes. 
Appendix 1
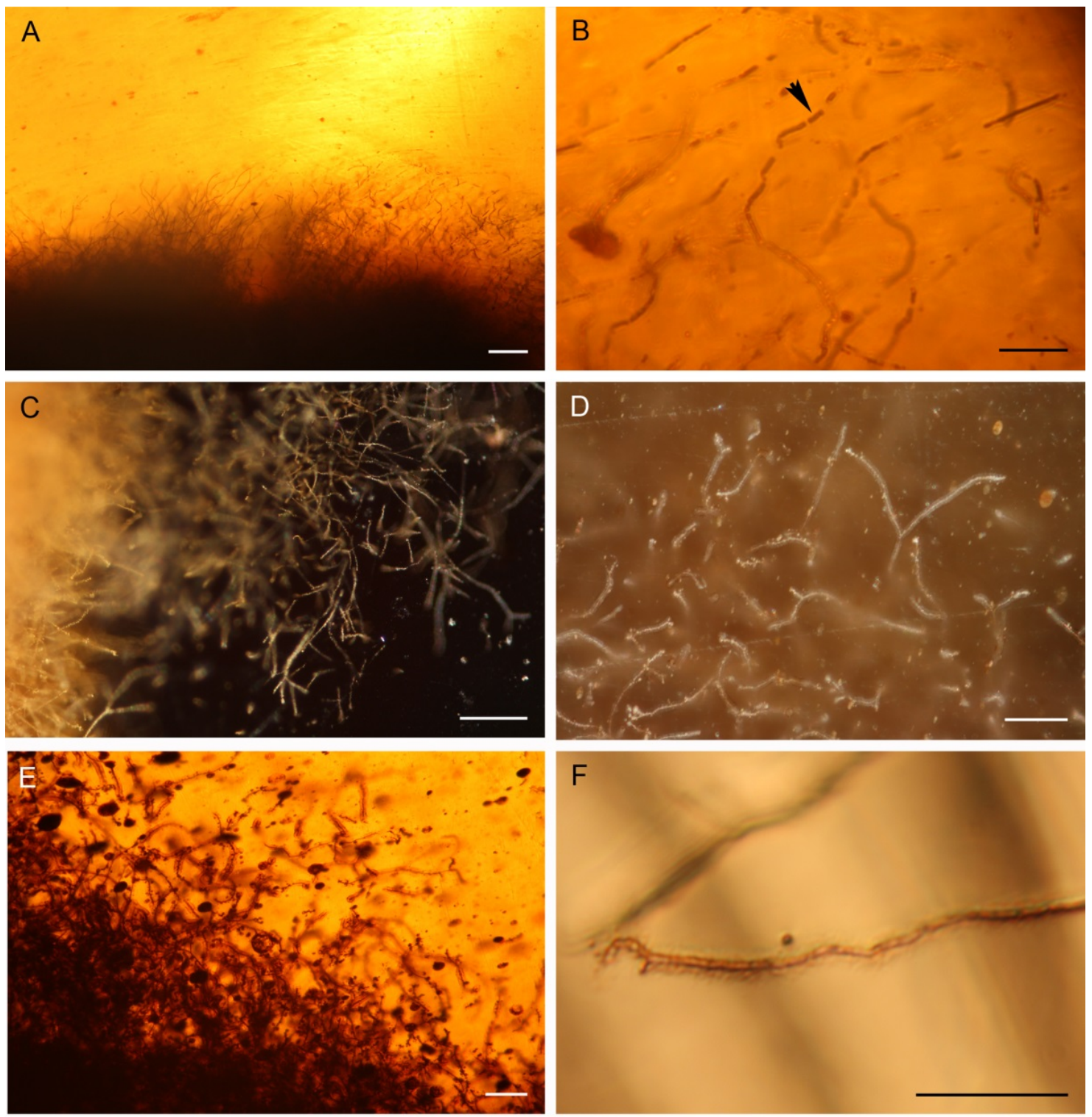

G
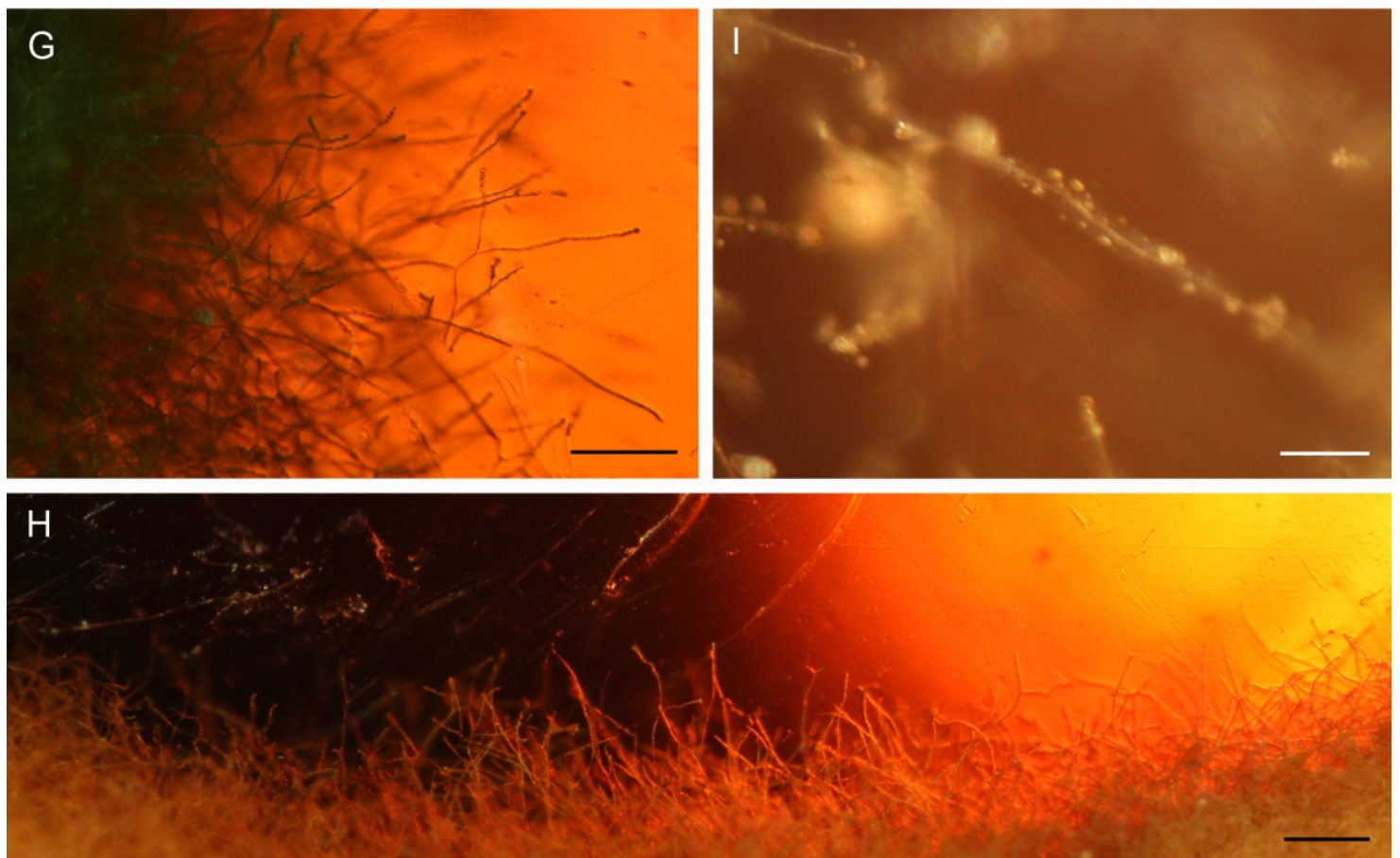
Figure 3. (previous page) Light-microscopical images of fossil microorganisms that have grown into the formerly liquid resin: A-B Fossil rod-shaped bacteria in Lower Cretaceous Golling amber from Austria (MB.Pb.2009/344). C-E Branched filaments of sheated bacteria in Albian amber from Santander (northern Spain; MB.Pb.2009/345 and 346). F Bacterial cell chain with only slightly developed sheath in Albian amber from Santander (GZG.BST 14979). G-H Sheated bacteria Upper Cretaceous amber from Kuji (Japan; BMNH V.65206). I Minute bubbles are sometimes visible inside the sheaths. Scale bars represent $500 \mu \mathrm{m} \mathrm{A}$ and $\mathrm{H}, 50 \mu \mathrm{m}$ in B-C, $100 \mu \mathrm{m}$ in $\mathrm{G}$, and $20 \mu \mathrm{m}$ in D, F and $\mathrm{I}$.
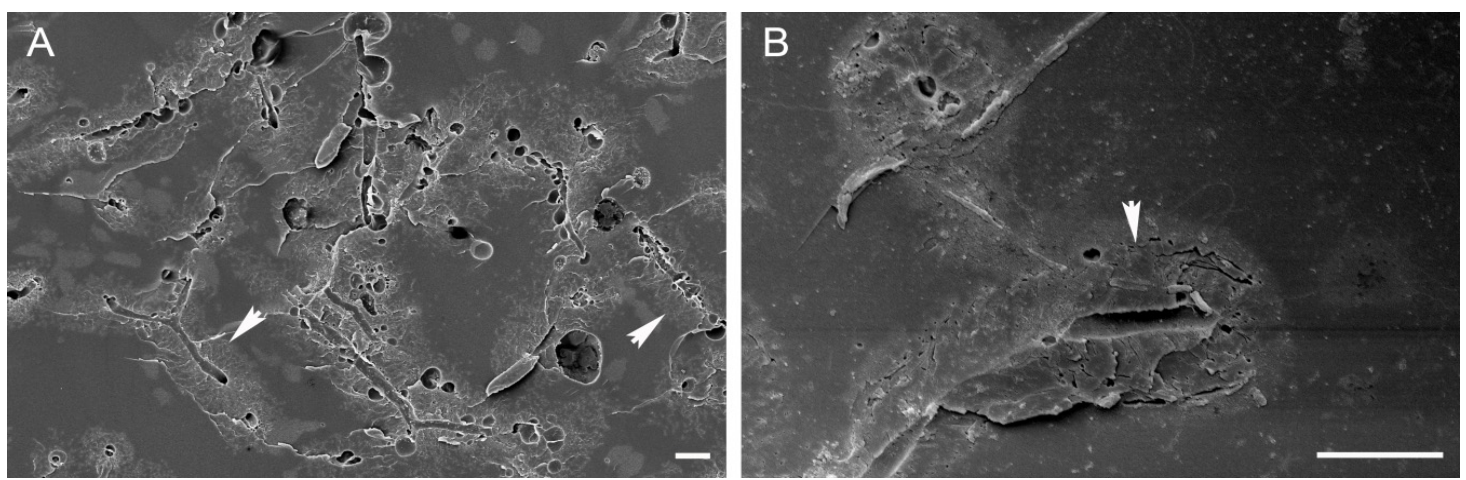

Figure 4. Scanning electron microscope images of sheathed bacteria visible at a break surfaces of Albian amber from Santander (Spain, GZG.BST 14978): A Several branched filaments are exposed at the surface. The arrows indicate the surface of the fossilized sheaths that are interspersed with minute bubbles. B Detailed view. The tubular hole inside the sheath at the former location of the cell chain is well visible. Scale bars represent $5 \mu \mathrm{m}$.

Modern sheathed bacteria of the genera Leptothrix and Sphaerotilus are chemoorganotrophic organisms, using a large number of carbon and nitrogen sources by tolerating a wide range of nutrient concentrations. Many carbohydrates, alcohols, organic acids and amino acids can be metabolized. Also the utilization of succinate as sole nutrient source was reported for modern sheathed bacteria. Resin, as an organic material, might be an appropriate habitat in liquid and possibly even in solid stage. Greenblatt et al. (2004) postulated, that bacteria of the genus Micrococcus may survive long times in cracks of amber pieces and possibly use amber compounds as a nutrient source. Most likely the Cretaceous filamentous bacteria that are preserved in amber used resin as a temporary habitat and could probably use compounds of the resin as a nutrient source. 

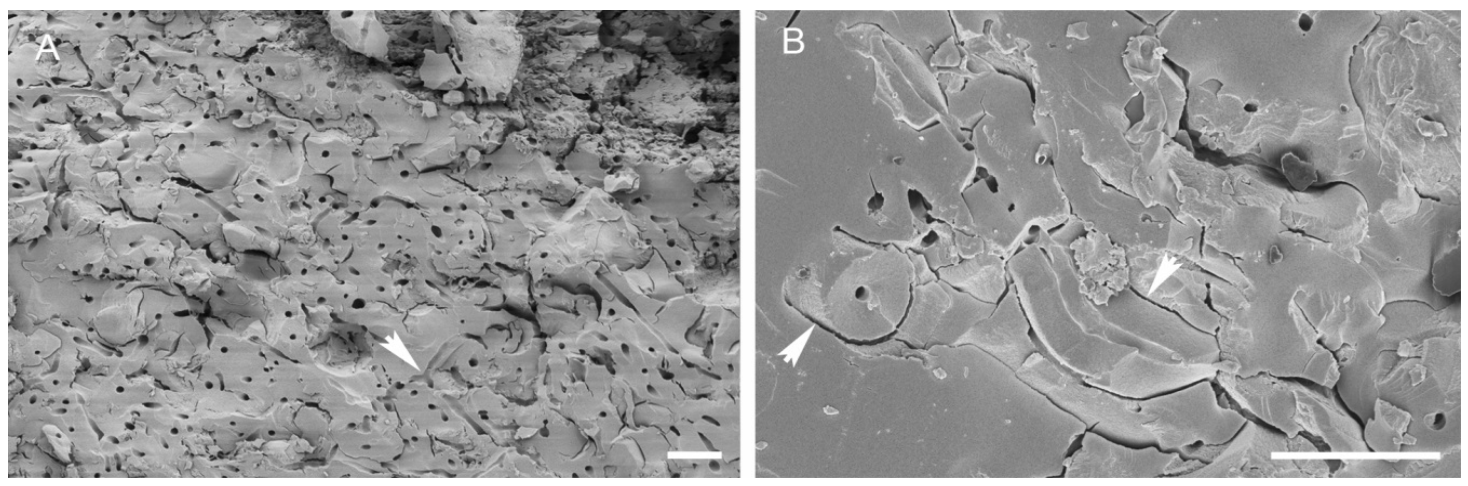

Figure 5. Scanning electron microscope images of resinicolous fungi grown into modern resin of Agathis lanceolata in New Caledonia (GZG.BST 14976): A Break surface of hardened resin interspersed by minute tubes that resulted by hyphal growth. The arrow indicates a branching. B Detail of the filamentous structures. The arrows indicate the sheath-like structure around the hyphae. Scale bars represent $10 \mu \mathrm{m}$.

We assume that these filamentous microorganisms came into contact to the resin flows at the forest floor and used this temporary microhabitat as long as possible. Peňalver et al. (2007) described similar filamentous structures from Cretaceous amber from San Just (Spain) as "alteration crust". These authors interpret these structures as nonbiological inclusions and suggest degradation structures caused by weathering of the amber pieces. According to our results, most "crusts" of Cretaceous ambers are not primarily caused by weathering but by colonization of liquid resin by filamentous microorganisms. It is, however, likely that numerous micrometer-sized tubes (see Fig. 4) that remain in the solidified resin promote subsequent physical-chemical weathering of the resin's outer parts.

Our experiments with living taxa demonstrated an active microbial colonization of liquid resin of Cycas revoluta and Pinus strobus (Fig. 2E). Growth of filaments could be observed after two or three days. Both, bacteria and fungi grew into the resins as long as it was liquid. The filaments stopped growing when the resin solidified. Interestingly, the Cycas-resin became darker around the hyphae (Fig. 2E) which might indicate some kind of interactions between compounds of the resin and fungal mycelia due to metabolic activity.

We found abundant fungal mycelia on recently solidified extensive resin flows of Agathis lanceolata from New Caledonia. In the humid forests of southeastern New Caledonia the resin flows were mostly completely overgrown by mycelia, causing a grey opaque surface of the translucent resin bodies. The hyphae did not exclusively grow at the resin surface but also penetrated the resin up to ca $3 \mathrm{~mm}$ deep which caused an opaque and fragile surface layer. These fungal mycelia are composed of very thin hyphae of only 1.5 to $3 \mu \mathrm{m}$ diameter that are densely arranged, irregular branched and sparsely septated (Fig. 2F-H). The numerous minute tubes caused by the fungal growth are shown in the SEM images of Fig. 5A and B. Around some of these tubes, an indication of a sheath appears (see Fig. 5B) that is not visible under the transmitted-light 
microscope. Possibly, this structure is caused by alteration of the surrounding resin due to metabolic activity of the hyphae. These resinicolous fungi from New Caledonia are probably representatives of the mycocaliciaceae group of ascomycetes whose representatives exclusively grow on resin and other exudates of vascular plants. Representatives of the genera Chaenothecopsis, Mycocalicium, Phaeocalicium and Stenocybe have been described to be resinicolous (see Tibell \& Titov (1995). Rikkinen (1999, 2003) described several new recent species from temperate rain forests of western North America and one extinct species, Chaenothecopsis bitterfeldensis, from 24 million-year-old amber from Germany (Rikkinen \& Poinar 2000). Because of their habitat specificity, it has been suggested that these fungi use liquid resin as sole nutrient source (see Rikkinen \& Poinar 2000).

Also many fossil resins contain fungal hyphae which have grown into the formerly liquid resin. Mycelia often cover inclusions of arthropods. Fungi that were probably attached to the animals when embedded continued growing until the resin solidified (Fig. 6A-B). Many amber pieces contain fungal hyphae that are densely arranged particularly in outer parts. Correspondingly to filamentous bacteria, fungal growth occurred from the surface to inner parts of the amber and the hyphae are orientated in many directions (Fig. 6C-D). These fungal hyphae also derived from the ancient environment and most likely came into contact with the resin at the forest floor.

We never found cyanobacteria growing into the resin. In contrast to the filiform bacteria illustrated and discussed above, these phototrophic organisms probably did not continue to grow extensively after being embedded in the liquid resin. Current reports of abundant cyanobacteria from French Cretaceous ambers (Girard et al. 2009a) are questionable since these results are mainly based on the putative detection of phycocyanin in these resins. These authors used a probe detecting fluorescence of the wave lengths that are specific for phycocyanian. However, they did not outline how they exclude measuring of the fluorescence of the amber itself. The fact that they often got higher signals in those parts of the amber that did not contain microinclusions confirms our doubts. 

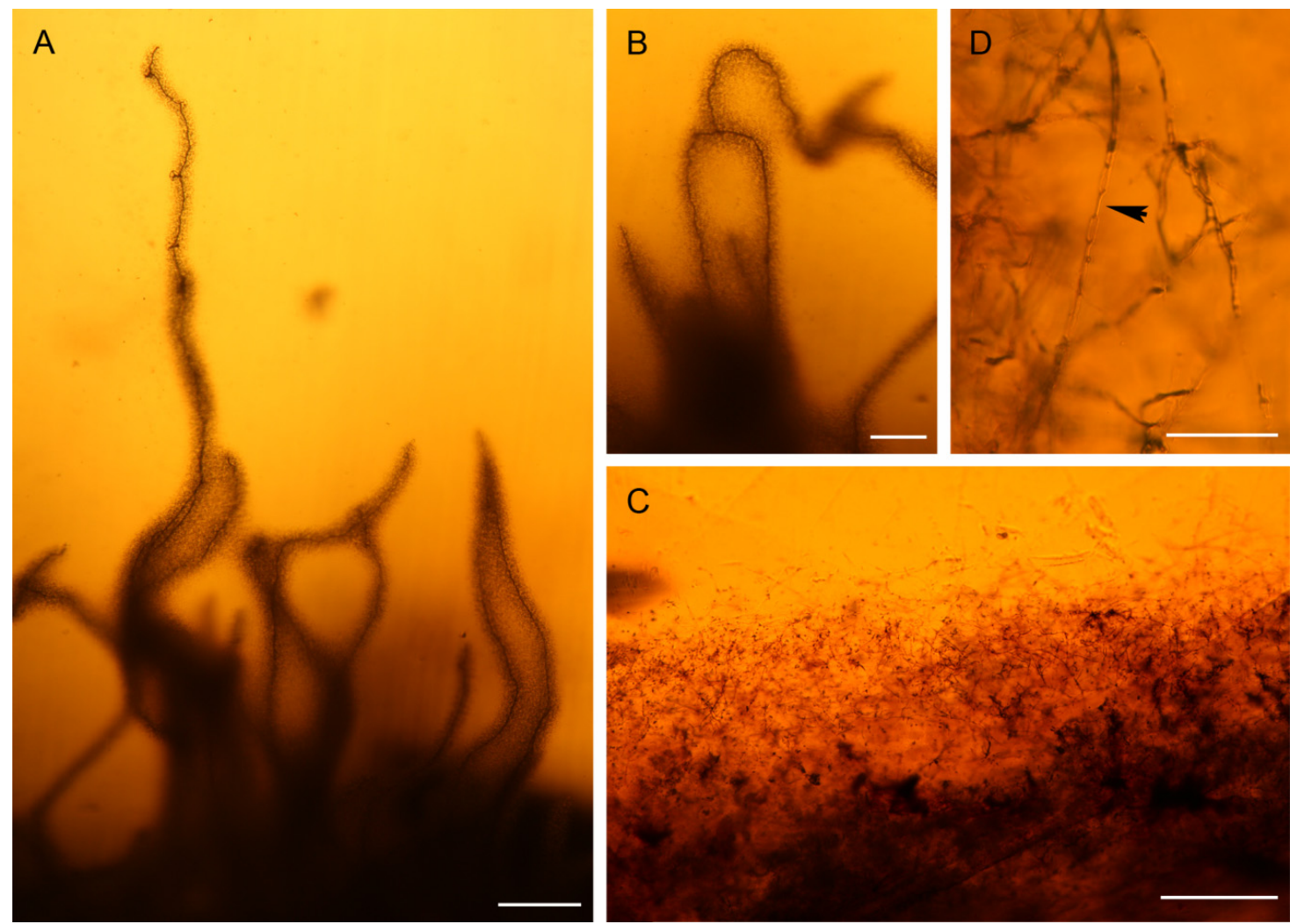

Figure 6. Light microscopical images of fossil fungi that have grown into the formerly liquid resin: A-B Branched hyphae at the surface of an insect enclosed in Baltic amber (amber collection of the Institute of Geology and Palaeontology of the University of Hamburg, coll. no. 1805). Note the darkened amber filaments that resembles the structures shown in Fig. 2E from modern resin . C-D Mycelium in Cretaceous Burmese amber (BMNH In 20206). The arrow indicates collapsed cells. Scale bars represent $50 \mu \mathrm{m}$ in $\mathrm{A}, \mathrm{B}$ and $\mathrm{D}$, and $500 \mu \mathrm{m}$ in $\mathrm{C}$.

\subsection{Microorganisms colonizing surfaces of solidified resins}

Investigating solidified modern resins in the field and ambers stored in collections, we found various examples of microbial colonization, too.The New Caledonian resin samplesof Agathis lanceolata and Agathis ovata that solidified at the forest floor or close to it at the tree trunk exhibited surfaces that were often covered by associations of bacteria, fungal mycelia and algae (Fig. 7A-B). These mycelia were distinguished from those of the resinicolous fungi mentioned above since their hyphae did not penetrate the resin bodies but overgrew their surfaces and bordering microhabitats.

Both, bacteria and fungi occurred on surfaces of Baltic amber samples of the Blumenbach collection. Hereby, fungal growth was predominantly observed. Some of these samples were strongly covered by fungal mycelia that sometimes plentiful sporulated (Fig. 7G-J). Molecular determination of the isolates revealed affiliations to the genus Aspergillus. 

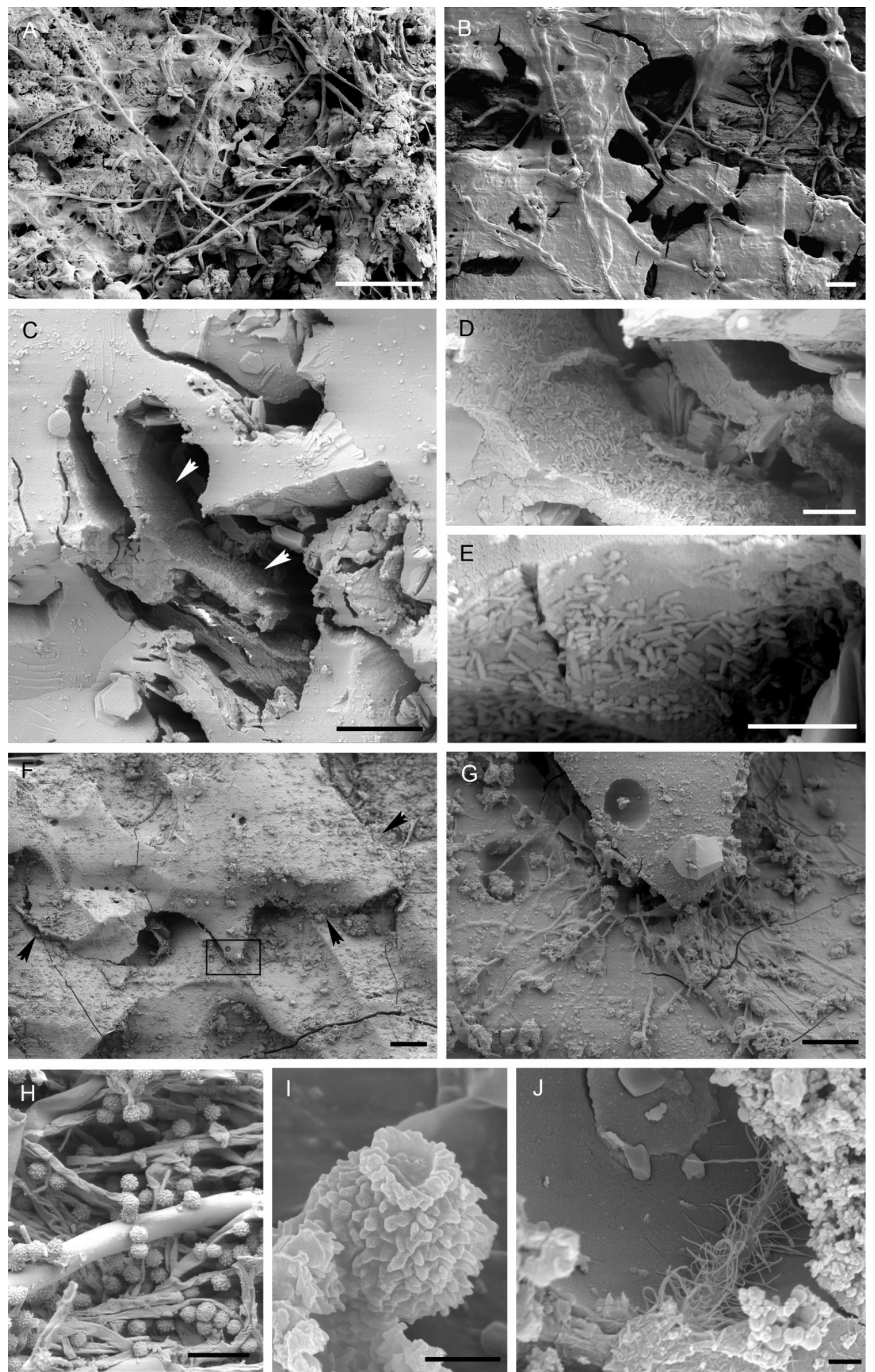
Figure 7. (previous page) Scanning electron microscope images of modern bacteria and fungi that colonize surfaces of solidified modern and fossil resins: A-B Hyphae at solidified resin of Agathis ovata (GZG.BST 14977), C-E Rod-shaped bacteria accumulated in deeper regions and fissures of surfaces of Baltic amber samples of the Blumenbach collection (GZG.HST 21). F-G Hyphae in cracks and minute fissures of Baltic amber samples of the Blumenbach collection (GZG.HST 19). H Sporulating Aspergillus sp. isolated from surface of Baltic amber of the Blumenbach collection. I Single spore of Aspergillus sp. $\mathbf{J}$ Fungal hyphae at the surface of Baltic amber of the Blumenbach collection (GZG.HST 19). Scale bars represent $50 \mu \mathrm{m}$ in $\mathrm{A}$ and $\mathrm{C}, 10 \mu \mathrm{m}$ in $\mathrm{B}, \mathrm{D}-\mathrm{E}$ and $\mathrm{G}-\mathrm{H}$, and $1 \mu \mathrm{m}$ in I-J.

Associated bacteria were mostly rod-shaped and showed affiliations to various classes, such as Betaproteobacteria, Gammaproteobacteria, Bacilli and Flavobacteria (Fig 7CE). It is well known that microorganisms, particularly in form of biofilms, can cover nearly all surfaces. We found bacteria and fungi preferentially in impressions of the amber surface and in fissures. This accumulation might be caused by improved growing conditions because of the presence of inorganic and organic matter including nutrients that accumulated in deeper regions and fissures. Whether amber as an organic material can be utilized as a nutrient source for microorganisms has not been examined so far, but it is conceivable. Due to the microbial activity, recent colonization may accelerate the degradation of the amber objects. The degradation of amber is probably caused by various chemical, physical and biological processes that may act together and sometimes trigger or enforce each other. Processes of oxidation are probably most important for the degradation of amber. However, when fungal mycelia penetrate into present fissures and extent their mycelia, physical forces arise that can break up upper amber layers, thus opening new areas for oxidation processes. So far, it is unclear if also secretion of metabolic compounds can represent a damaging factor and if the microbes may utilize amber compounds as a nutrient source. This should be subject of further studies.

Usually, recent biofilms are easily distinguishable from fossil inclusions using highmagnification light-microscopy. Also, microorganisms that are situated inside fissures that extend into the amber are usually distrainable from microinclusions when tracing the refractive micrometre-sized fissures under the microscope. During the study of midCretaceous amber of southwestern France, Girard et al. (2008a) discovered living marine and freshwater diatoms at the amber surface and in micrometre-sized fissures. Furthermore, these authors found fungal mycelia, bacteria and cyanobacteria in fissures inside the amber samples, showing that not exclusively ambers in collections represent habitats of microorganisms. 


\section{Acknowledgments}

We thank Jérôme Munzinger (Nouméa) for supporting the field work in New Caledonia and David L. Dilcher (Gainesville) for making the field studies in Florida possible. We are indebted to Mike Reich (Göttingen) for amber loans from the Blumenbach collection of Baltic amber, to Wolfgang Weitschat (Hamburg) for loans of Baltic amber, to Johann Peschl (Laufen) for providing Cretaceous amber from Austria, to Markus Wilmsen (Würzburg) for Cretaceous amber samples from Spain, and to Ulf-Christian Bauer (Schliersee) for donating samples of Cedar Lake amber. Hilary Ketchum and Claire Mellish (London) kindly provided access to the amber collection of the Natural History Museum in London. We acknowledge with thanks the help of Dorothea HauseReitner and Andreas Reimer (Göttingen) during the SEM analyses and the help of Kerstin Schmidt (Jena) in the preparation of the manuscript. We heartily thank Joachim Reitner (Göttingen) for technical support and for his kind invitation to contribute to this special issue. This is contribution number 39 from the Courant Research Centre Geobiology that is funded by the German Initiative of Excellence. 


\section{References}

Austin J, Ross AJ, Smith AB, Fortey RA \& Thomas RH (1997) Problems of reproducibility - does geologically ancient DNA survive in amber-preserved insects? Proc R Soc Lond B Biol Sci 264:467-621

Berkeley MJ (1848) On three species of mould detected by Dr. Thomas in the amber of East Prussia. Ann Mag Nat Hist (Series 2) 2:380-383

Blunck G (1929) Bakterieneinschlüsse im Bernstein. Zbl Min Geo Pal 11:554-555

Cano RJ, Borucki MK, Higby-Schweizer M, Poinar HN, Poinar GO Jr \& Pollard KJ (1994) Bacillus-DNA in fossil bees: an ancient symbiosis? Appl Environ Microbiol 60:2164-2167

Caspary R \& Klebs R (1907) Die Flora des Bernsteins und anderer fossiler Harze des ostpreußischen Tertiärs. Abhandlungen der Königlich-Preußischen Geologischen Landesanstalt 4:1-181

Cognato A.I. \& Grimaldi D.A. (2009) 100 million years of morphological conservation in bark beetles (Coleoptera: Curculionidae: Scolytinae). Syst Entomol 34:93-100

Cruickshank RD \& Ko K (2003) Geology of an amber locality in the Hukawng valley, Northern Myanmar. J Asian Earth Sci 21:441-445

Dörfelt H \& Schäfer U (2000) Palaeozygnema spiralis, ein Vertreter der Conjugatophyceae in mesozoischem Bernstein aus Bayern. Hoppea 61:785-793

Dörfelt H \& Schmidt AR (2007) A conifer seedling with two herbicolous fungi from the Baltic amber forest. Bot J Linn Soc 155:449-456

Galippe V (1920) Recherches sur la résistance des microzimas àlàction du temps er sur survivance dans làmbre. C.R. hebdo. Acad Sci Paris 170:856-858

Girard V, Néraudeau D, Breton G (2008a) Contamination of amber samples by recent microorganisms and remediation evidenced by Mid-Cretaceous amber of Charentes (SW France), Geomicrobiol J 26:21-20

Girard V, Schmidt AR, Saint Martin S, Struwe S, Perrichot V, Saint Martin JP, Grosheny D, Breton G, \& Néraudeaua D (2008b) Evidence for marine microfossils from amber. Proc Natl Acad Sci USA 105:17426-17429

Girard V, Breton G, Brient L, Néraudeau D (2009a) Sheathed prokaryotic filaments, major components of Mid-Cretaceous French amber microcoenoses. J Paleolimnol 42:437-447

Girard V, Schmidt AR, Struwe S, Perrichot V, Breton G \& Néraudeau D (2009b) Taphonomy and palaeoecology of mid-Cretaceous amber-preserved microorganisms from southwestern France. In: Perrichot V \& Néraudeau D (eds) Studies on midCretaceous amber from southwestern France. Geodiversitas 31:153-162

Greenblatt CL, Davis A, Clement BG, Kitts CL, Cox T \& Cano RJ (1999) Diversity of microorganisms isolated from amber. Microb Ecol 38:58-68 
Greenblatt CL, Baum J, Klein BY, Nachson S \& Cano RJ (2004) Micrococcus luteus survival in amber. Microb Ecol 48:120-127

Grimaldi DA, Engel MS \& Nascimbene PC (2002) - Fossifiliferous Cretaceous amber from Myanmar (Burma): its rediscovery, biotic diversity and paleontological significance. Am Mus Novit 3361:1-72

Hofreiter M, Serre D, Poinar HN, Kuch M \& Pääbo S (2001) Ancient DNA. Nat Rev Genet 2:353-359

Krumbiegel G \& Krumbiegel B (2005) Bernstein - Fossile Harze aus aller Welt. Goldschneck Verlag, Wiebelsheim

Lambert LH, Cox T, Mitchell K, Rosselló-Mora, RA, Del Cueto C, Doge DE, Orkland P \& Cano RJ (1998) Staphylococcus succinus sp. nov., isolated from Dominican amber. Int J Syst Bacteriol 48:511-518

McKellar RC, Wolfe AP, Tappert R \& Muehlenbachs K (2008) Correlation of Grassy Lake and Cedar Lake ambers using infrared spectroscopy, stable isotopes and palaeoentomology. Can J Earth Sci 45:1061-1082

Peňalver E, Delclòs X \& Soriano C (2007) A new rich amber outcrop with palaeobiological inclusions in the Lower Cretaceous of Spain. Cretaceous Research 28:791-802

Poinar H, Cano R, Poinar G. (1993) DNA from an extinct plant. Nature 363:677

Rikkinen J (1999) Two new species of resinicolous Chaenothecopsis (Mycocaliciaceae) from western North America. Bryologist 102:366-369

Rikkinen J (2003) Chaenothecopsis nigripunctata, a remarkable new species of resinicolous Mycocaliciaceae from western North America. Mycologia 95:98-103

Rikkinen J \& Poinar GO Jr (2000) A new species of resinicolous Chaenothecopsis (Mycocaliciaceae, Ascomycota) from 20 million year old Bitterfeld amber, with remarks on the biology of resinicolous fungi. Mycol Res 104:7-15

Ritzkowski S (1999) Das geologische Alter der bernsteinführenden Sedimente in Sambia (Bezirk Kaliningrad), bei Bitterfeld (Sachsen-Anhalt) und bei Helmstedt (SE Niedersachsen) In: KosmowskaCeranowicz B, Paner H. (eds) Investigations into amber. Proceedings of the InternationalInterdisciplinary Symposium: Baltic amber and other fossil resins, 2-6 September 1997: 33 40, Gdansk, Poland

Schmidt AR \& Schäfer U (2005) Leptotrichites resinatus new genus and species: a fossil sheathed bacterium in alpine Cretaceous amber. J Paleontol 79:175-184

Schmidt AR \& Dilcher DL (2007) Aquatic organisms as amber inclusions and examples from a modern swamp forest. Proc Natl Acad Sci USA 104:16581-16585

Schmidt AR, Schönborn W \& Schäfer U (2004) Diverse fossil amoebae in German Mesozoic amber. Palaeontology 47:185-197

Schmidt AR, Ragazzi E, Coppellotti O \& Roghi G (2006) A microworld in Triassic amber. Nature 444:835 
Schönborn W, Dörfelt H, Foissner W, Krienitz L \& Schäfer U (1999) A fossilized microcenosis in Triassic amber. J Eukaryot Microbiol 46:571-584

Standke G (2008) Bitterfelder Bernstein gleich Baltischer Bernstein? - Eine geologische Raum- Zeit-Betrachtung und genetische Schlußfolgerungen. In: Rascher J, Wimmer R, Krumbiegel G \& Schmiedel S (eds) Bitterfelder Bernstein versus Baltischer Bernstein - Hypothesen, Fakten, Fragen. Exkursionsführer und Veröffentlichungen der Deutschen Gesellschaft für Geowissenschaften 236:11-33

Tibell L \& Titov A (1995) Species of Chaenothecopsis and Mycocalicium (Caliciales) on exudate. Bryologist 98:550-560

Ting WS \& Nissenbaum A (1986) Fungi in Lower Cretaceous amber from Israel. Special Publication by the Exploration and Development Research Center, Chinese Petroleum Corporation, Miaoli, Taiwan

Vávra N (2005) Bernstein und verwandte organische Minerale aus Österreich. Beiträge zur Paläontologie von Österreich 29:255-280

Waggoner BM (1993) Fossil actinomycetes and other bacteria in Eocene amber from Washington State, USA. Tertiary Research 14:155-160

Waggoner BM (1994) Fossil microorganisms from Upper Cretaceous amber of Mississippi. Rev Palaeobot Palynol 80:75-84

Waggoner BM (1996) Bacteria and protists from Middle Cretaceous amber of Ellsworth County, Kansas. PaleoBios 17:20-26

Willerslev E \& Cooper A (2005) Ancient DNA. Proc R Soc Lond B Biol Sci. 272:3-16

Willerslev E, Hansen AJ \& Poinar HN (2004) Isolation of nucleic acids and cultures from fossil ice and permafrost. Trends Ecol Evol 19:141-147

Wilmsen M (1997) Das Oberalb und Cenoman im Nordkantabrischen Becken (Provinz Kantabrien, Nordspanien): Fazesentwicklung, Bio- und Sequenzstratigraphie. Berliner Geowiss Abh E 23:1-167 


\section{Appendix 2}

Tuovila H, Schmidt AR, Beimforde C, Dörfelt H, Grabenhorst H, Rikkinen J (2013) Stuck in time - a new Chaenothecopsis species with proliferating ascomata from Cunninghamia resin and its fossil ancestors in European amber. Fungal Diversity 58, 199-213.

Impact factor of Fungal Diversity 2011: 4.749, according to Journal Citation Reports 


\title{
Stuck in time - a new Chaenothecopsis species with proliferating ascomata from Cunninghamia resin and its fossil ancestors in European amber
}

\author{
Hanna Tuovila $^{\mathrm{a}}$, Alexander R. Schmidt ${ }^{\mathrm{b}}$, Christina Beimforde ${ }^{\mathrm{b}}$, Heinrich Dörfelt ${ }^{\mathrm{c}}$, \\ Heinrich Grabenhorst ${ }^{\mathrm{d}}$ and Jouko Rikkinen ${ }^{\mathrm{a}}$
}

\author{
${ }^{a}$ Department of Biosciences, P.O. Box 65, FIN-00014 University of Helsinki, Finland, ${ }^{b}$ Courant \\ Research Centre Geobiology, Georg-August-Universität Göttingen, Goldschmidtstraße 3, 37077 \\ Göttingen, Germany, ${ }^{\mathrm{c}}$ Mikrobielle Phytopathologie, Friedrich Schiller-Universität Jena, Neugasse 25, \\ 07743 Jena, Germany, ${ }^{\mathrm{d}}$ Nachtigallenweg 9, 29342 Wienhausen, Germany
}

Corresponding author: Jouko Rikkinen (jouko.rikkinen@helsinki.fi)

\begin{abstract}
Resin protects wounded trees from microbial infection, but also provides a suitable substrate for the growth of highly specialized fungi. Chaenothecopsis proliferatus is described growing on resin of Cunninghamia lanceolata from Hunan Province, China. The new fungus is compared with extant species and two new fossil specimens from Eocene Baltic and Oligocene Bitterfeld ambers. The Oligocene fossil had produced proliferating ascomata identical to those of the newly described species and to other extant species of the same lineage. This morphology may represent an adaptation to growing near active resin flows: the proliferating ascomata can effectively rejuvenate if partially overrun by fresh, sticky exudate. Inward growth of fungal hyphae into resin has only been documented from Cenozoic amber fossils suggesting comparatively late occupation of resin as substrate by fungi. Still, resinicolous Chaenothecopsis species were already well adapted to their special ecological niche by the Eocene, and the morphology of these fungi has since remained remarkably constant.
\end{abstract}

Keywords. Fossil fungi. Proliferating ascomata. Resin compounds. Ecology. Taxonomy 


\section{Introduction}

Resinous exudates provide plants with protection against pathogens and parasites, but some highly specialized fungi are also known to grow exclusively on resin substrates. In the Mycocaliciales Tibell \& Wedin (Eurotiomycetes, Ascomycota) some ten percent of the approximately 150 known species grow on plant exudates (Tibell and Titov 1995; Rikkinen 1999, 2003a; Titov 2006; Tuovila et al. 2011a, 2011b). Most of these fungi live on conifers and produce perennial, stipitate ascomata on hardened resin and/or resin-impregnated wood. Some species are also able to colonize relatively fresh, semisolid resin. The ability to rapidly exploit new substrates is advantageous, but also carries the inherent risk of being buried by subsequent resin flows. This danger is well exemplified, not only by the occurrence of partially or completely submerged ascomata in modern resins, but also by submerged specimens in European amber dating back to the Oligocene (Rikkinen and Poinar 2000) and Eocene (this study).

Here, we describe a new resinicolous Chaenothecopsis species from the exudate of Cunninghamia lanceolata (Lamb.) Hook. (Cupressaceae) from Hunan Province, China, as well as newly discovered Chaenothecopsis fossils from Eocene Baltic and Oligocene Bitterfeld ambers dating back to at least 35 and 24 million years ago, respectively. The exquisite preservation of the fossils allows a detailed comparison with extant relatives. One fossil fungus has produced branched and proliferating ascomata similar to those of the newly described species from China, as well as some other extant species of the same lineage.

\section{Material and Methods}

\section{Extant and fossil fungi}

Resinicolous fungi were collected from tree trunks of Cunninghamia lanceolata (Cupressaceae), Ailanthus altissima (Mill.) Swingle (Simaroubaceae), Kalopanax septemlobus (Thunb.) Koidz (Araliaceae), and Pinus massoniana Lamb. (Pinaceae) in warm temperate evergreen broadleaved forests in Zhangjiajie National Forest Park (1999), Badagongshan National Nature Reserve (1999, 2000), Daweishan National Forest Park (2000), and Shunhuangshan National Forest Park (2001) of Hunan Province in south-central China. For more information on the study area, see Koponen et al. (2000, 2004).

The fossils with proliferating ascocarps (Fig. 7) are preserved attached to wood debris in a $17 \times 13 \times 5 \mathrm{~mm}$ piece of Bitterfeld amber from the Heinrich Grabenhorst collection (collection number Li-83) that is now housed in the Geoscientific Collections 
of the Georg August University Göttingen (collection number GZG.BST.27285). Bitterfeld amber originates from the Goitzsche mine near the city of Bitterfeld (central Germany) and was recovered from the "Bernsteinschluff" Horizon in the upper part of the Cottbus Formation. The Upper Oligocene amber-bearing sediment has an absolute age of 25.3-23.8 million years (Blumenstengel 2004; Knuth et al., 2002). A previous notion that Bitterfeld amber either represents re-deposited Eocene Baltic amber, or is at least much older than the amber-bearing strata (Weitschat 1997) was disproven by recent reconstructions of the sedimentary environment of this huge amber deposit (see Standke 2008, and discussion in Schmidt and Dörfelt 2007, and Dunlop 2010).

The non-proliferating fossil ascocarps (Figs 8 and 9) are enclosed in a $2.5 \times 1.5 \times 1$ $\mathrm{cm}$ piece of Baltic amber from the Jörg Wunderlich collection (collection number F1178/BB/FUN/CJW) that is now housed in the Geoscientific Collections of the Georg August University Göttingen (collection number GZG.BST.27286). Four immature and six mature ascomata derive from a mycelium that directly grew on the surface of a stalactite-like resin piece which served as substrate for the resinicolous fungus. These were preserved by a subsequent resin flow that had then covered over the material. The Eocene sediments containing the majority of Baltic amber in the Kaliningrad area (Russia) are 35-47 million years old (Standke 1998).

\section{Microscopy, imaging and microanalysis}

Morphological features of the extant fungal specimens were observed and measured in water under a light microscope (Leica DMLS) with a 100x oil-immersion objective. Potassium-hydroxide (KOH), Lugol's reagent (IKI), Melzer's reagent (MLZ), Congo Red (CR; CR+ congophilous, coloring strongly red in $\mathrm{CR}$ ), and nitric acid (N) were used when observing some diagnostic structures, like paraphyses and stipe hyphae. Ascomata from dried Cunninghamia bark pieces were imaged under a Carl Zeiss AxioScope A1 compound microscope using simultaneously incident and transmitted light. Spores were imaged on a microscope slide in water using $1600 \times$ (oil immersion) magnification and Differential Interference Contrast (DIC) illumination.

For scanning electron microscopy, several dried specimens of $C$. proliferatus were removed from the substrate, placed on a carbon-covered SEM-mount, sputtered by gold/palladium and examined under a Carl Zeiss LEO 1530 Gemini field emission scanning-electron microscope as described by Beimforde et al. (2011). Energydispersive X-ray spectroscopy (EDX) was performed on some ascomata using an INCA-EDX system (Oxford Instruments) with an excitation voltage of $15 \mathrm{KV}$ at this electron microscope. 

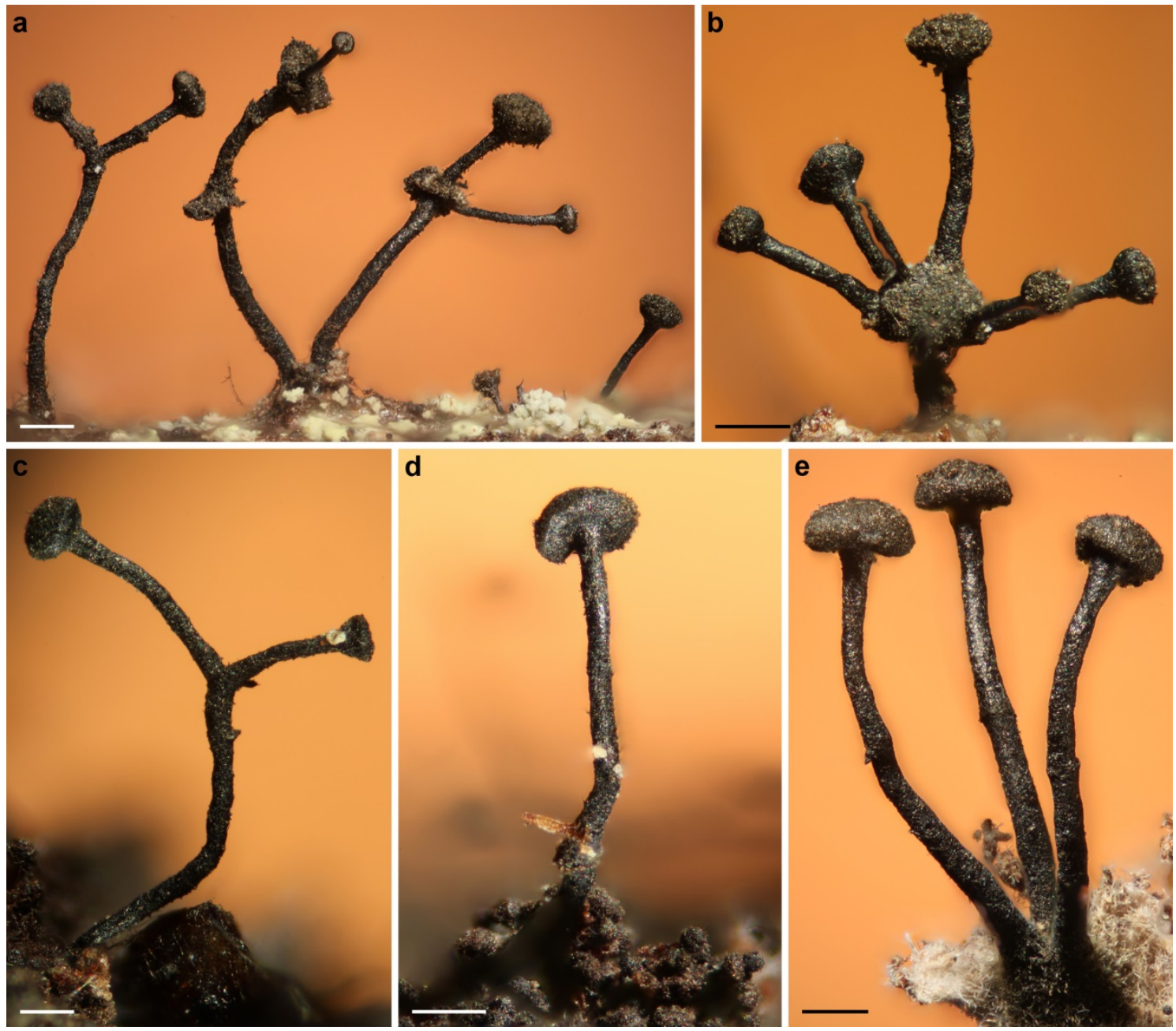

Fig. 1 Ascomata of Chaenothecopsis proliferatus sp. nov. on resin-impregneted bark of Cunninghamia lanceolata. a Proliferating ascomata (JR 990048). b Multiple branching from capitulum (holotype, JR 990061). c Ascoma with branched stipe (holotype, JR 990061). d Mature non-branched ascoma on resin (holotype, JR 990061). e Non-branched ascomata rising from a common stroma; note dense aerial mycelium (holotype, JR 990061). Scale bars: $200 \mu \mathrm{m}$.

The amber pieces were ground and polished manually with a series of wet silicon carbide abrasive papers to remove the weathered crusts and to minimize light scattering for the investigation. Prepared specimens were placed on a glass microscope slide with a drop of water applied to the upper surface of the amber, and covered with a glass coverslip. The inclusions were studied using a Carl Zeiss AxioScope Al compound microscope. In most instances, incident and transmitted light were used simultaneously (see Schmidt et al. 2012, for protocols). In order to protect the amber from oxidation and breakage, the polished Baltic amber piece was embedded using polyester resin as described by Hoffeins (2001).

Images of Figs 1, 2, and 7 to 9 (except of Figs 2e, $7 \mathrm{~g}$, and 9f, g) are digitally-stacked photomicrographic composites obtained from several focal planes using the software package HeliconFocus 5.0 for a better illustration of the three-dimensional objects. 

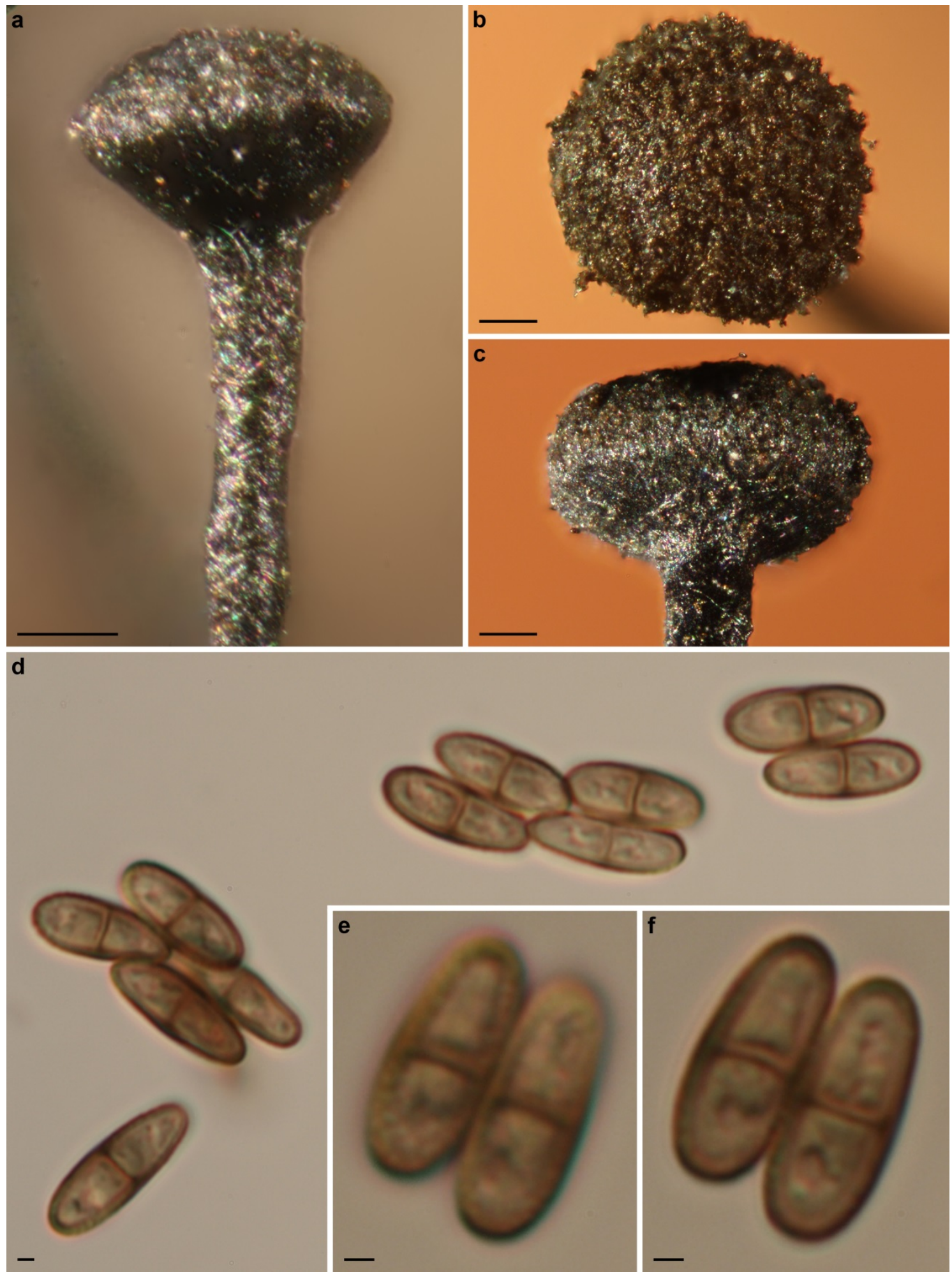

Fig. 2 Capitulum and spores of Chaenothecopsis proliferatus sp. nov. (holotype, JR 990061). a Young capitulum and upper section of stipe; note intertwined surface hyphae. b Capitulum with thin mazaedium seen from above. c Exciple. d Ascospores. e Spore wall in focus. f Septum in focus. Scale bars: $50 \mu \mathrm{m}$ (ac) and $1 \mu \mathrm{m}(\mathrm{d}-\mathrm{f})$. 


\section{DNA extraction, PCR amplification and sequencing}

DNA was extracted from extant representative specimens of resinicolous fungi collected from Hunan Province. Additional resinicolous, lignicolous and parasitic fungi were collected from different localities in Finland (2009) and northwestern USA (2006). DNA was extracted from 5 to 10 ascomata of each species with the NucleoSpin@Plant DNA extraction kit (Macherey-Nagel) with the following modification to the manufacturer's protocol: specimens were incubated for 2 hours to ensure the lysis of the ascocarps. The nuclear large subunit ribosomal RNA (LSU) partial gene was amplified using the primers LR0R and LR3 (Rehner and Samuels 1994; Vilgalys and Hester 1990). The ITS region of rDNA was amplified using the primers ITS4 and ITS5 (White et al. 1990) or alternatively ITS4 and ITS1F (Gardes and Bruns 1993). PCR amplification was conducted using Phusion ${ }^{\circledR}$ High-Fidelity DNA Polymerase (Thermo scientific/Finnzymes) according to the manufacturer's specifications using a 1:4 dilution of template DNA. PCR products were purified with GeneJET ${ }^{\mathrm{TM}}$ PCR Purification Kit (Fermentas). Amplicons were sequenced by Macrogen Inc. (South Korea) in the forward and reverse directions using the same primers as during amplification. Sequences for each sample were assembled into contigs using Geneious v5.4 (Drummond et al. 2011) and the consensus sequences used for further analyses. For samples that failed to amplify using the Phusion PCR method, amplification was conducted using PuReTaq Ready-To-Go PCR Beads (GE Healthcare, Piscataway NJ, USA) according to the manufacturer's instructions with the primers LROR \& LR7 (Vilgalys and Hester, 1990) or ITS1F \& ITS4, and $3 \mu 1$ of template DNA in a total PCR reaction volume of $25 \mu \mathrm{l}$. These amplicons were then sequenced using an ABI 3100 automated sequencer (Applied Biosystems Inc., Foster City, CA, USA) with the primers ITS1F \& ITS4, and LROR, LR3, LR5, and LR7.

\section{Phylogenetic analyses}

A concatenated dataset was composed of both the ITS and LSU sequences that were generated, and previous accessions from NCBI GenBank. The GenBank sequences were selected following two criteria: both ITS and LSU sequences were from the same voucher material (with the exception of Mycocalicium sequoiae from which only the LSU sequence was available), and sequences were from species with unequivocal taxonomic status. The dataset was aligned with MAFFT version 6 (Katoh and Toh 2008) and adjusted manually in PhyDE® 0.9971 (Müller et al. 2010). Unequivocal short (1-3 nucleotides) uninformative insertions were first removed from the alignment, and the program Gblocks 0.91 (Castresana 2000) was then used to remove ambiguously aligned 
regions. Phylogenetic relationships and confidence statistics were inferred using a partitioned Bayesian approach in which models of evolution were generated independently with jModeltest 1.1 (Posada 2008) for each of the gene regions (LSU, ITS1, 5.8S, ITS2). The suggested evolutionary models (TIM2ef $+\mathrm{G}, \mathrm{HKY}+\mathrm{G}$, TIM2ef $+\mathrm{G}$, TIM3ef $+\mathrm{G}$, respectively) were implied for the partitioned dataset analyses. Bayesian analyses employing four Markov chain Monte Carlo (MCMC) chains were carried out with MrBayes 3.1.2 (Ronquist and Huelsenbeck 2003) on the freely available computational resource Bioportal at the University of Oslo (http://www.bioportal.uio.no; Kumar et al. 2009). The four chains were run simultaneously for 10 million generations for the partitioned datasets with trees sampled every 100th generation. Average standard deviations of split frequency (ASDSF) values lower than 0.01 were taken as an indication that convergence had been achieved. A burn-in sample of 5000 trees was discarded for the run and the remaining trees were used to estimate branch lengths and posterior probabilities. Additional support values were estimated using the same model parameters in Garli 2.0 for maximum likelihood (Zwickl 2006) with 1000 bootstrap searchreps. Voucher information and GenBank accession numbers of all fungal specimens used in this study are listed in Table 1.

\section{Results}

\section{Extant fungus from China}

Chaenothecopsis proliferatus Rikkinen, A. R. Schmidt et Tuovila sp. nov. Figs 1-5

MycoBank no.: MB800706

Type: China. Hunan Province. Dayong County, Zhangjiajie National Forest Park. Fuqiyan, along trail to view point above Zhangjiajie Hotel; young mixed Cunninghamia-angiosperm forest with large remnant Pinus massoniana. On resin, resin-soaked bark, and lignum of Cunninghamia lanceolata. 15.IX.1999, 29 $19^{\prime} \mathrm{N}$, $110^{\circ} 25^{\prime}$ E, elev. 650 m, Rikkinen JR990061 (holotype H).

Etymology: proliferatus refers to the common production of branched and proliferating ascocarps in this species.

Description: Apothecia on resin or resin-soaked wood and bark of Cunninghamia lanceolata, small to medium, 800-2000 $\mu \mathrm{m}$ high, black with a bluish tinge. Stipe shiny black, long and slender, occasionally branching, 30-80 $\mu \mathrm{m}$ wide. Capitulum discoid to 
lentil-shaped, rarely subspheric or ovoid, bluish black, 170-250 × 300-400 $\mu \mathrm{m}$. Young capitulum shiny, later spores accumulate as agglomerates on top of capitulum, appearing as black spots. Old capitulum covered with brown hyphae that possibly originate from germinated spores. New apothecia proliferate often from old capitula, usually several from the same capitulum. All parts of apothecium N- and MLZ-. Asci arise from croziers, cylindrical, 64.0-81.0 × 3.5-4.5 $\mu \mathrm{m}(\mathrm{n}=10)$, apex variously thickened and often penetrated by a short canal, mature asci sometimes without thickening. Hymenium and hypothecium IKI+, reaction fast and only seen by adding fresh IKI to a partly dried water squash preparation while observing through the microscope. The blue reaction usually disappears in seconds after the IKI has penetrated the material, the speed and the strength of the reaction seems to vary depending on the age and pigmentation of the ascocarp. Ascospores uniseriately and periclinally arranged, sometimes partly obliquely arranged in asci, brownish green, cylindrical to fusoid, oneseptate, in mature spores septum as thick as spore wall, the spore wall inwardly thickened at junction between septum and spore wall; $(7.2-) 7.5-11.3(-11.8) \times 3.1-4.3$ (-4.6); mean $10.3 \times 3.4 \mu \mathrm{m}(\mathrm{n}=90$, from 9 ascocarps, 6 populations $) ; \mathrm{Q}=1.9-3.6 \mu \mathrm{m}$, mean $\mathrm{Q}=3$.0. Spores smooth under the light microscope, but each examined ascocarp typically had a small ratio (less than $15 \%$ ) of young spores with very minute, pointed ornamentation. Paraphyses hyaline, filiform, $65-85 \times 1.0-1.5 \mu \mathrm{m}$, occasionally branching from lower sections, commonly branching at the ascus tip level; septate, septal intervals 5.0-15.0 $\mu \mathrm{m}$. Paraphyse tips covered with hyaline, strongly congophilous crystals that dissolve with $\mathrm{KOH}$. Hypothecium hyaline to light green. Exciple green to brownish green in young apothecia, dark (greenish) brown in older ones, hyphae parallel, 3.0-4.0 $\mu \mathrm{m}$ wide, cell wall $0.5-1.5 \mu \mathrm{m}$, often with colorless crystals between and on top of hyphae of exciple, dissolving in $\mathrm{KOH}$ and MLZ; $\mathrm{KOH}+$ yellowish brown color leaks into medium and green pigments turn brown. Faint, but persisting grayish red to purplish pink IKI+ reaction in thick-walled hyphae of exciple. Reaction is often difficult to observe due to the strong pigmentation of hyphal walls. Stipe dark green in young apothecia to dark brown in older ones, hyphae more or less parallel, partly intertwined, 3.0-5.0 $\mu \mathrm{m}$ wide, cell wall $1.5-2.0 \mu \mathrm{m}, \mathrm{KOH}+$ dark brown color leaks into medium and green colors of stipe turn brown. All parts of exciple and stipe covered with dense net of arching and horizontal hyphae $3.0 \mu \mathrm{m}$ wide, cell wall 0.5-1.0 $\mu \mathrm{m}$. Epithecium greenish to yellowish brown, composed of elements from exciple and paraphyses. The thick-walled hyphae of exciple cover the asci, intertwine and form a tight net that is hard to break, with small holes, on average $3.0 \mu \mathrm{m} \times 4.0 \mu \mathrm{m}$ in size. Paraphyses curve at the level of ascus tips to cover the asci, branch repeatedly and anastomose with neighboring branches of the same and adjoining paraphyses just beneath the net of excipular hyphae, forming an inner layer of the epithecium. This 


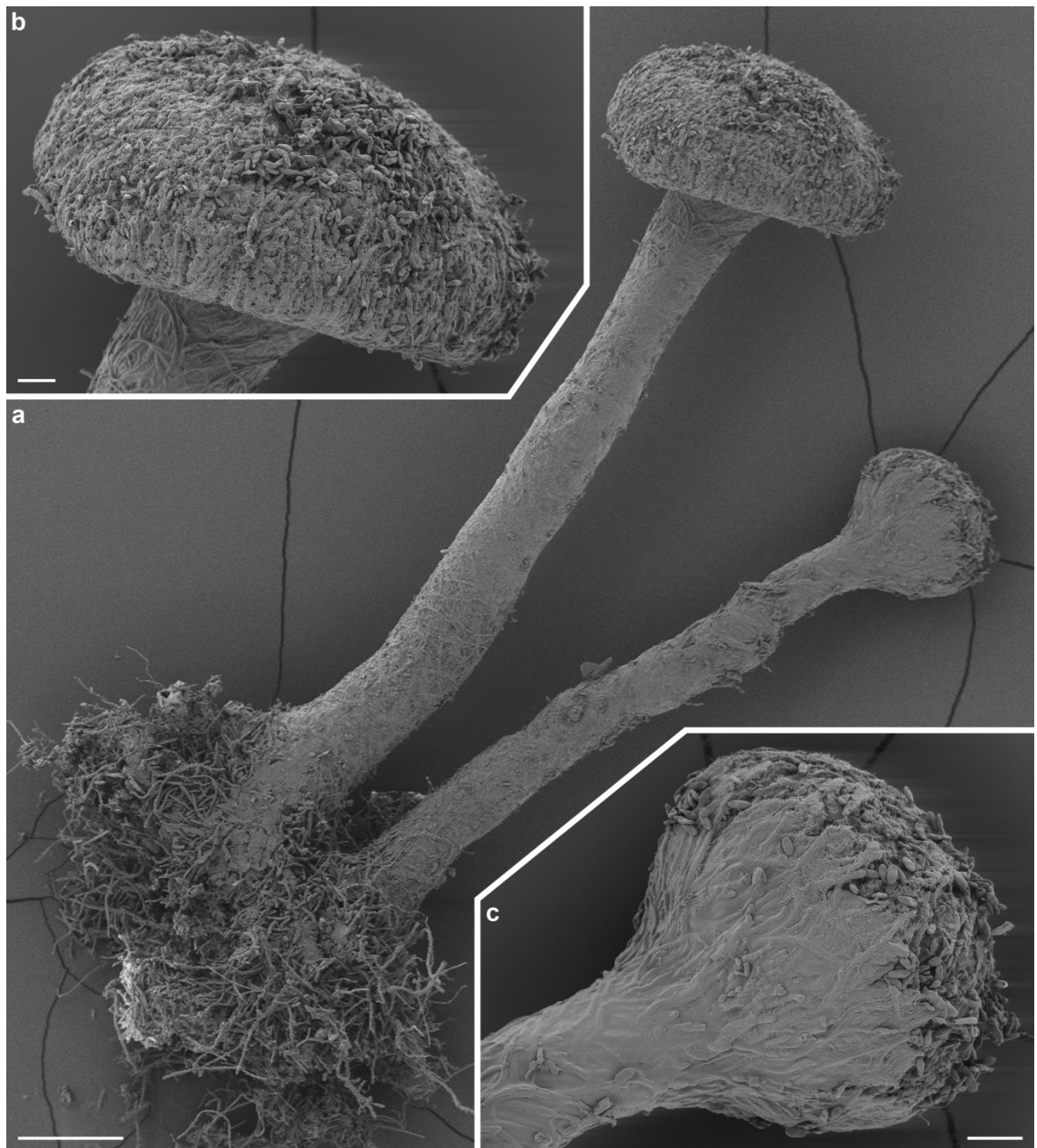

Fig. 3 SEM images of ascomata of Chaenothecopsis proliferatus sp. nov. (holotype, JR 990061). a Ascomata. b Detail of epithecium. c Detail of exciple. Scale bars: $100 \mu \mathrm{m}$ (a) and $20 \mu \mathrm{m}$ (b and c).

complex contains innumerable colorless, strongly congophilous crystals. Crystals also appear between paraphyses and asci, usually as a 15-20 $\mu \mathrm{m}$ thick layer. The crystals dissolve and green colors of epithecium turn brown in $\mathrm{KOH}$. Faint, but persisting grayish red to purplish pink IKI+ reaction in thick-walled hyphae of epithecium, usually difficult to observe due to the dark pigmentation of cell walls. 

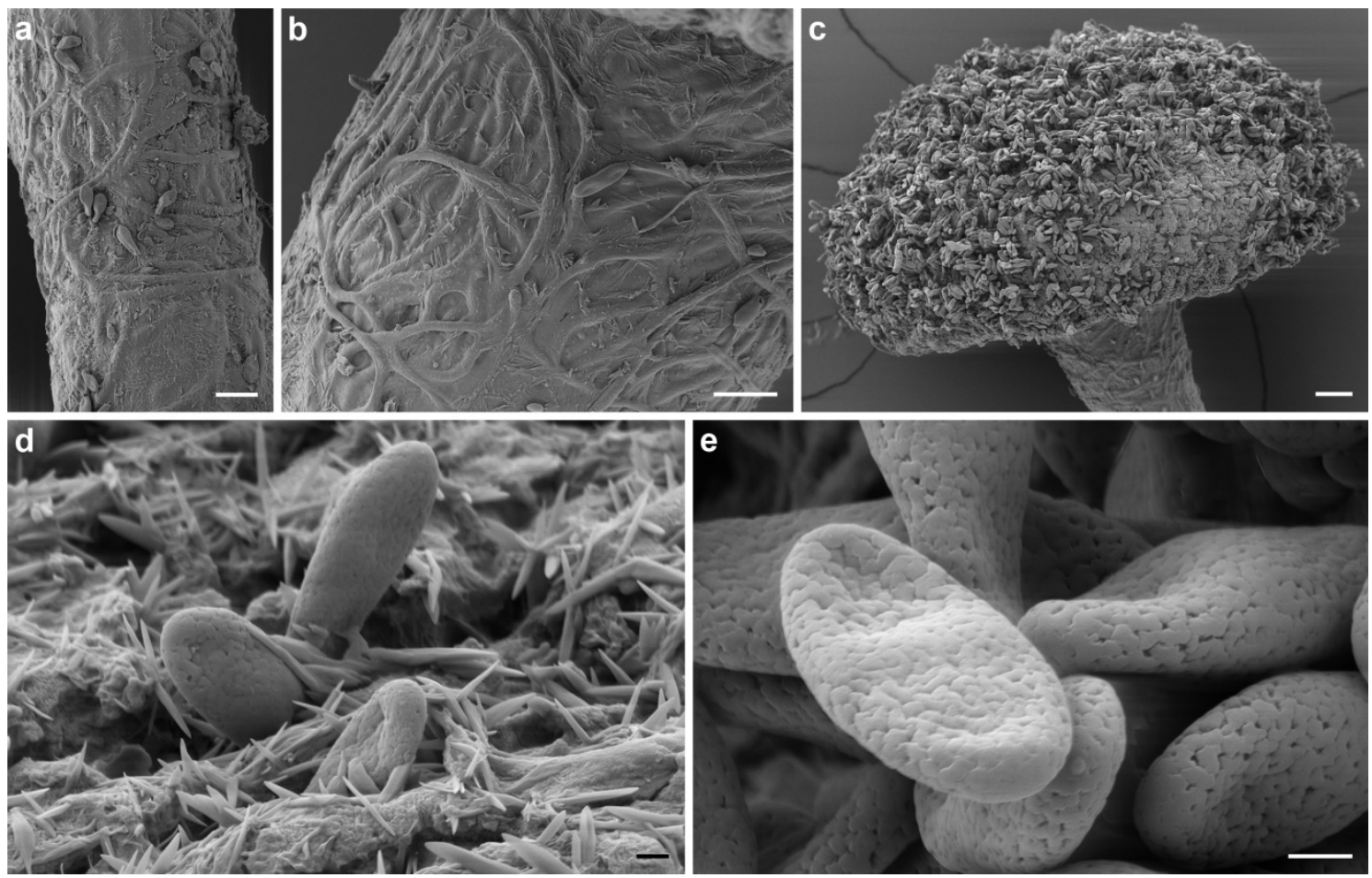

Fig. 4 SEM images showing anatomical details of Chaenothecopsis proliferatus sp. nov. (holotype, JR 990061). a Stipe surface. b Stipe surface near exciple. c Epithecium. d Ascospores being released through the epithecium; note the blade-like crystals. e. Ascospores. Scale bars: $10 \mu \mathrm{m}$ (a and b), $20 \mu \mathrm{m}$ (c) and 1 $\mu \mathrm{m}(\mathrm{d}$ and $\mathrm{e})$.

\section{Specimens studied}

China. Hunan Province. Resinicolous on basal trunk of Cunninghamia lanceolata. Dayong Co., Zhangjiajie National Forest Park. Dense mixed Cunninghamia-angiosperm forest along roadside in moist valley, 15.IX.1999. $29^{\circ} 19^{\prime} \mathrm{N}, 110^{\circ} 24^{\prime} \mathrm{E}$, elev. $785 \mathrm{~m}$, Rikkinen JR990047, JR990048. Fuqiyan, along trail to view point above Zhangjiajie Hotel, young mixed Cunninghamia-angiosperm forest with large remnant Pinus

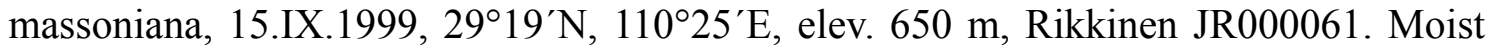
evergreen forest with bamboo and conifer stands in valley below Zhangjiajie Hotel,

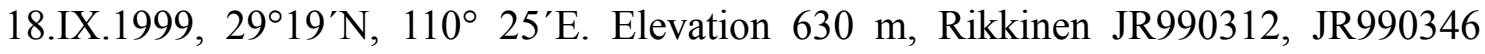
(SKLM). Yaozizhai, along lowest section of trail from valley bottom towards the peak, mature Cunninghamia lanceolata plantation along dry stream bed, 20.IX.1999, $29^{\circ} 18^{\prime} \mathrm{N}$, $110^{\circ} 25^{\prime}$ E, elev. 610 m, Rikkinen JR990484. Liu Yang Co., Daweishan National Forest Park. Xu-Quan Hu, low broadleaved secondary thickets with isolated Cunninghamia lanceolata in moist valley, 28.IX.2000, $28^{\circ} 25.30^{\prime} \mathrm{N}, 114^{\circ} 06.95^{\prime} \mathrm{E}$, elev. ca. $1300 \mathrm{~m}$, Rikkinen JR000470. Lower section of trail from Li-Mu-Qiao to Wu-Zi-Shi crossing, secondary mixed evergreen forest with bamboo stands on steep slope of moist river valley, 28.IX.2000, 28 $25.50^{\circ} \mathrm{N}, 14^{\circ} 05.35^{\prime} \mathrm{E}$, elev. ca. 1000 m, Rikkinen JR000594, JR000595. Xinning Co., Shunhuangshan National Forest Park. Zheng Jiang Valley. 
Cunninghamia lanceolata/Trachycarpus fortunei stand in grazed mixed evergreen secondary forest, 24.IX.2001, 2624'35'N, 11059’20” E, elev. 950 m, Rikkinen JR010543.

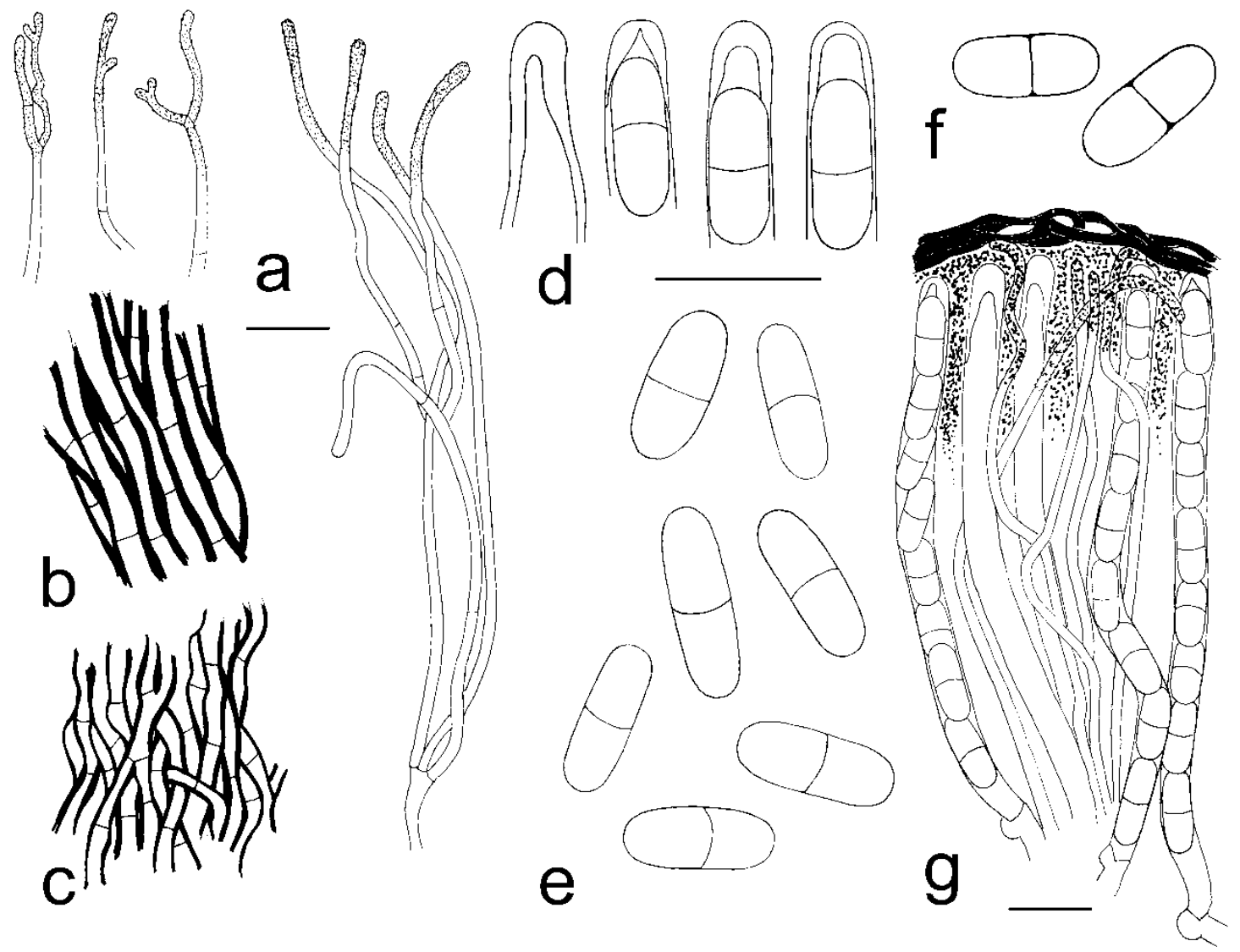

Fig. 5 Line drawings of anatomical details of Chaenothecopsis proliferatus sp. nov. a Paraphyses (JR990346, JR000595). b Stipe (JR990048). c Exciple (JR990048). d Ascus tip (JR990061, JR000595). e Ascospores (JR990048, JR990061, JR990312, JR000595). f Spore wall (JR990312). g Paraphyses, asci, and epithecium (JR000593). Scale bars: $10 \mu \mathrm{m}$.

\section{Phylogenetic analysis}

The fungal LSU and ITS sequences obtained from extant Chaenothecopsis specimens in this study and from GenBank were highly variable. There were no major indels in the LSU and 5.8S sequences, so these regions could be unambiguously aligned with Mafft. Conversely, the ITS1 and ITS2 sequences of most species had several apparently independent indels; , in some cases tens of nucleotides long. Such unambiguous regions were removed before analysis. The lengths of sequences used in the phylogentic analyses were: ITS1 $137 \mathrm{bp}$ (60\% of the original 227 positions), 5.8SR $155 \mathrm{bp}$ (99\% of 156 positions), ITS2 $130 \mathrm{bp}$ (54\% of 238 positions), and partial LSU 534 bp (97\% of 548 positions). The resulting alignment has been uploaded to TreeBase, direct accession: http://purl.org/phylo/treebase/phylows/study/TB2:S12780. 


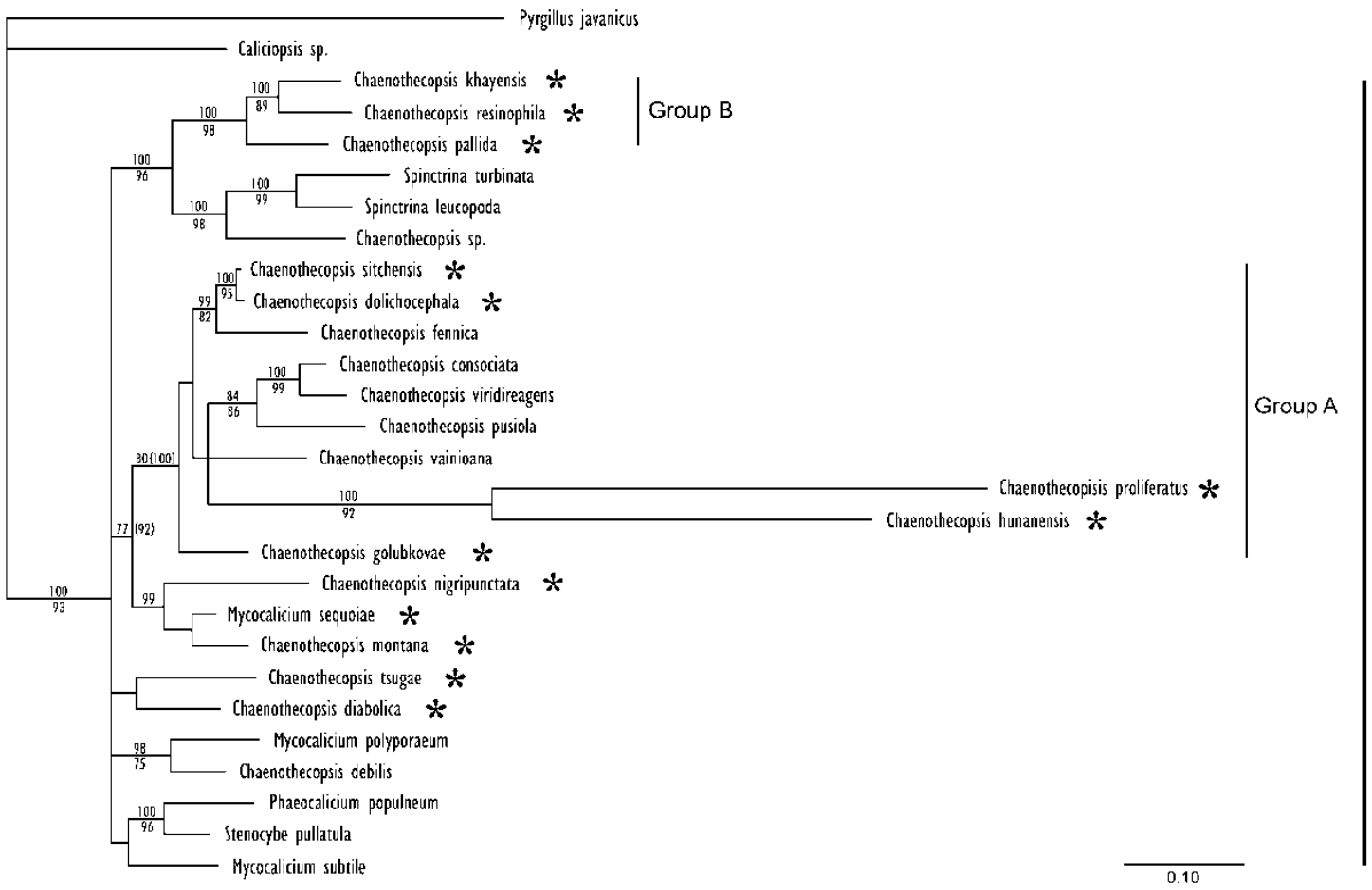

Fig. 6 Phylogenetic relationship of Chaenothecopsis proliferatus based on analysis of ITS and partial LSU sequences. Support values are indicated for nodes that received support from at least one method (Bayesian posterior probabilities shown above the nodes; maximum-likelihood bootstrap values shown below the nodes). Chaenothecopsis proliferatus and $C$. hunanesis had a negative effect on the posterior probabilities of the tree. The values in parenthesis refer to posterior probabilities when these two species were not included in the analysis. The clade corresponding to the Mycocaliciales is shown by a vertical bar, and the resinicolous species are indicated by an asterisk. See original publication for accession numbers of the used species. Group A species with one-septate ascospores. Groups B species with aseptate ascospores from angiosperm exudates

The results of the phylogenetic analysis are shown in Figure 6. The phylogeny is broadly consistent and adds to the previous results of Tibell and Vinuesa (2005) and Tuovila et al (2011a). It places $C$. proliferatus in the same clade with several other Chaenothecopsis species with one-septate spores. This clade includes taxa that grow on conifer resins, a species that grows on conifer lignum, and several species that are either lichen-parasitic or associate with free-living green algae.

Chaenothecopsis proliferatus and the closely related C. hunanesis Rikkinen \& Tuovila (ined.) had a negative effect on the posterior probabilities of the tree. If these species were removed from the dataset, the other species showed qualitatively similar groupings with higher posterior probabilities (tree not shown). This is probably explained by the fact that only LSU sequences were available for these two new species from China; presumably due to the relatively old age of the specimens (over 10 years), we were not able to amplify ITS sequences from them. Without information from ITS 
sequences, there is a level of uncertainty regarding the exact placement of these two taxa within their clade. In an analysis based solely on LSU sequences, the sister group relationship between the four lichen-parasitic taxa and the clade of $C$. dolichocephala, C. sitchensis and C. fennica gained higher support, but the placement of C. proliferatus remained unresolved (tree not shown).

\section{Fossil specimens from European amber}

Amber piece GZG.BST.27285 (Bitterfeld amber) contains fossilized remains of over 45 stipitate fungal ascomata (Figs 7a-b). These represent different developmental stages from young initials to mature and senescent ascomata. Individual ascomata erect, $250-$ $1100 \mu \mathrm{m}$ high, forming stacks of up to three ascomata of different ages by proliferating and branching (Figs 7a-c). Exciple well-developed, smooth, with partly intertwined surface hyphae (Figs $7 \mathrm{~d}-\mathrm{e}$ ). Stipe slender, 30-80 $\mu \mathrm{m}$ in diameter, smooth, with partly intertwined hyphae (Figs 7b-d). Tufts of anchoring hyphae penetrate the substrate (Figs 7a-b). Ascospores narrowly ellipsoidal to cylindrical, one-septate, 9-10.5 $\times 3.5-4.5 \mu \mathrm{m}$, appearing smooth under the light microscope (Figs $7 \mathrm{f}-\mathrm{g}$ ).

Amber piece GZG.BST.27286 (Baltic amber) contains fossilized remains of at least 15 stipitate fungal ascomata (Fig. 8a). These include ten well-preserved ascomata (4 immature, 6 mature) and at least five degraded ascomata. Many details not visible due to weathered crust around the latter inclusions. Ascomata erect and non-branching, 1500-1840 $\mu \mathrm{m}$ high when mature (Figs 8a, 9a). Immature, developing ascomata with sharply pointed apices (Figs 9b-c). Capitula lenticular to subhemispheric, 260-380 $\mu \mathrm{m}$ wide and 120-200 $\mu \mathrm{m}$ high, with a well-developed exciple (Fig. 9a). Mature ascospores have accumulated on top of epithecium (Fig. 9d). Stipe long and rather robust, 90-160 $\mu \mathrm{m}$ in diameter, smooth or with a somewhat uneven surface of partly intertwined hyphae. (Fine details not visible due to thin film of air around the inclusions) (Figs 9ae). Tufts of anchoring hyphae attach the ascomata to the substrate (Figs 9a-b) and penetrate deeply into the resin (Figs 8b-c). Ascospores narrowly ellipsoidal to cylindrical, one-septate, $8-11 \times 3-4 \mu \mathrm{m}$, appearing smooth under the light microscope (Figs 9f-g). 

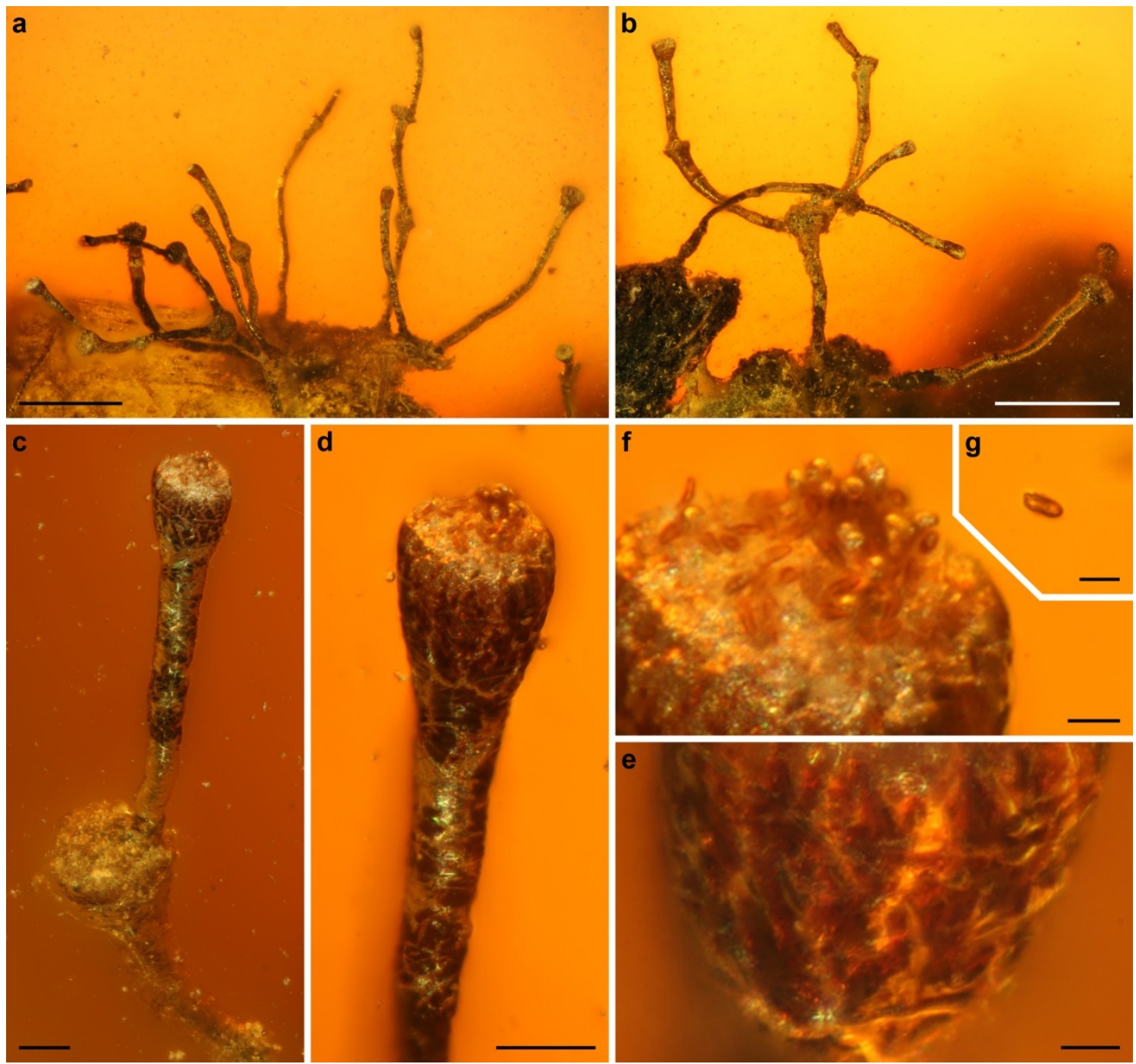

Fig. 7 Fossil Chaenothecopsis from Bitterfeld amber (GZG.BST.27285). a-b Proliferating ascomata. cd Young ascoma. e Exciple. f. Epithecium, note the accumulation of ascospores. $\mathrm{g}$ Detached ascospore. Scale bars: $500 \mu \mathrm{m}$ (a and b), $50 \mu \mathrm{m}$ (c and d) and $10 \mu \mathrm{m}(\mathrm{e}-\mathrm{g})$.

\section{Discussion}

\section{Taxonomy and evolutionary relationships}

In their substrate ecology, general morphology, and in the production of septate ascospores, Chaenothecopsis proliferatus and the two newly described fossils closely resemble each other, as well as several other Chaenothecopsis species from Eurasia and western North-America. The phylogenetic analyses indicate that $C$. proliferatus is closely related to previously known species that live on conifer resin and have oneseptate ascospores (Group A in Fig. 6). In as much as both fossils had produced similar spores, and because Baltic and Bitterfeld ambers are fossilized conifer resins, these fossils are likely to belong to this same lineage. 

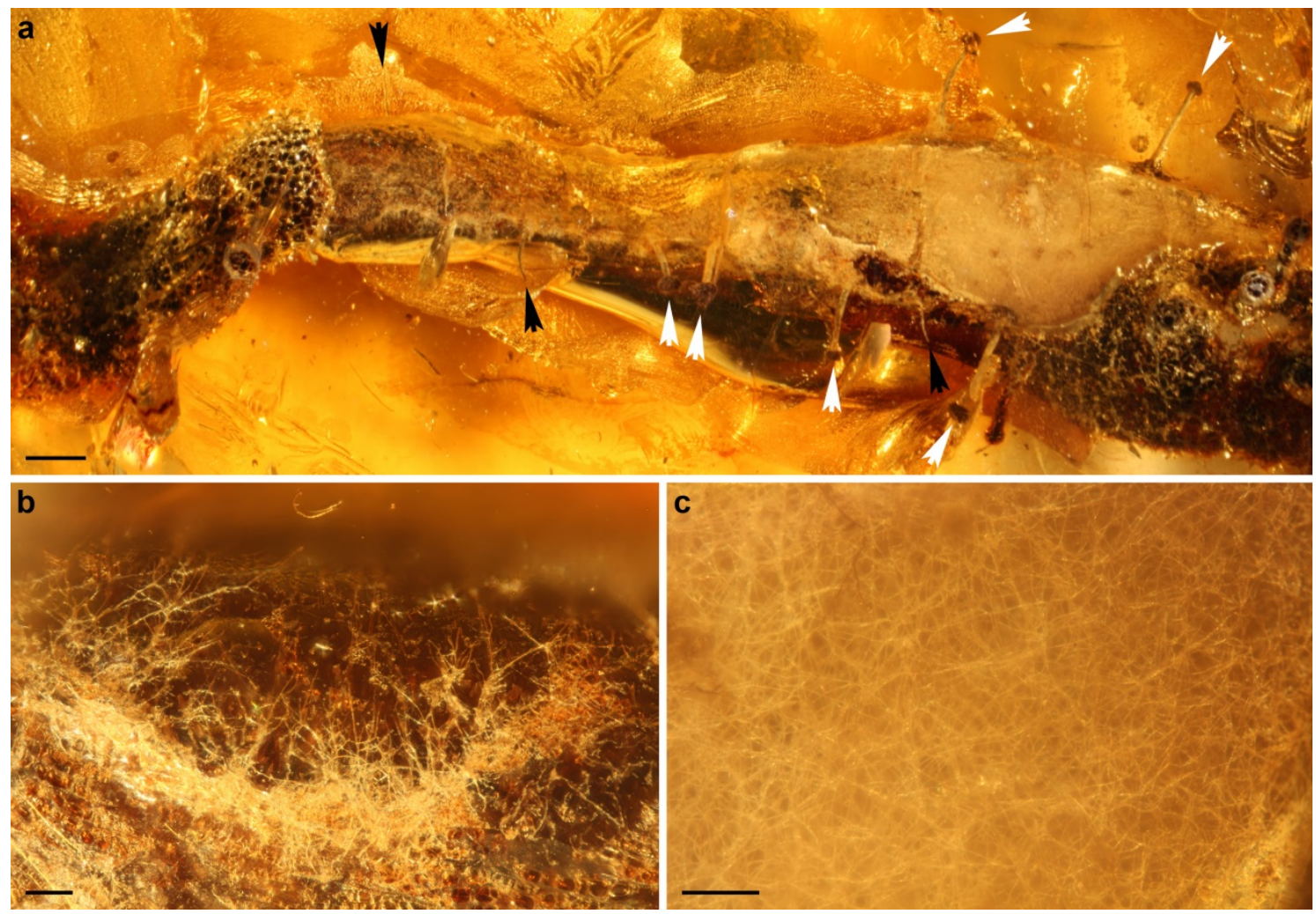

Fig. 8 Overview of the fossil Chaenothecopsis from Baltic amber (GZG.BST.27286). a Ascomata on a stalactite-like piece of solidified resin which was subsequently covered by fresh exudate. Black arrowheads point to young developing ascomata, white arrowheads to mature ascomata. b Fungal hyphae that grew on and into the stalactite-like resin substrate before it solidified. c Dense mycelium on the old resin flow. Scale bars: $1 \mathrm{~mm}(\mathrm{a})$ and $100 \mu \mathrm{m}$ (b and c).

No Chaenothecopsis species with aseptate spores were included in this lineage, and the phylogenetic analysis grouped three such species from angiosperm exudates into a different well-supported clade (Group B in Fig. 6), as a sister group to the two Sphinctrina species. As the substrate preferences of Mycocaliciales are highly specialized, and spore septation is an important taxonomic character, only resinicolous Chaenothecopsis species with one-septate ascospores are here compared with $C$. proliferatus and the two fossils. Chaenothecopsis sitchensis Rikkinen, C. nigripunctata Rikkinen, and $C$. edbergii Selva \& Tibell grow on conifer resin in temperate North America and often produce large and robust ascocarps. C. sitchensis lacks the fast IKI+ reactions typical of $C$. proliferatus and has distinctively ornamented ascospores (Rikkinen 1999). C. nigripunctata has larger spores than C. proliferatus and a highly distinctive appearance due to its gray, compound capitula (Rikkinen 2003b). C. edbergii differs from $C$. proliferatus in having a persisting blue MLZ+ reaction in the hymenium and a lime green pruina on the surface of its ascomata (Selva and Tibell 1999).

Compared to Chaenothecopsis proliferatus, C. eugenia Titov (Titov 2001) and C. 
asperopoda Titov (Titov and Tibell 1993) both have smaller spores, very thin septa and a diagnostic stipe structure and coloration. These two species appear to be closely related, but unfortunately we were unable to extract sufficient DNA for sequencing, presumably due to the old age (ca. 20 years) of the type material. Both species have a fast blue IKI+ reaction of the hymenium and an IKI+ red reaction of stipe similar to $C$. proliferatus. The latter color reaction is more easily observed in these species than in $C$. proliferatus because their stipes are less pigmented.

Chaenothecopsis dolichocephala (Tibell and Titov 1995), C. golubkovae (Titov and Tibell 1993) and C. hunanensis are very similar to C. proliferatus. C. dolichocephala often produces branched and proliferating fruiting bodies, has similar colorless crystals in the hymenium, and also shares a similar anatomy of the stipe and exciple. However, its ascomata are on average smaller, the stipe is shinier and the ascospores are ornamented. The blue IKI+ reaction is very faint or non-existing and the red IKI+ reaction occurs only in the lower part of exciple and stipe, if at all. The spore size, epithecial structure and the IKI+ color reactions of $C$. golubkovae are more or less identical to those of $C$. proliferatus. However, this $C$. golubkovae is characterized by the highly branched and irregularly shaped hyphae (textura epidermoidea) formed from fused cell walls of the exciple and stipe. C. hunanensis has slightly smaller spores with thin septa and a different type of epithecium when compared with $C$. proliferatus.

The distinction between C. proliferatus, C. dolichocephala, C. golubkovae and $C$. hunanensis requires study of anatomical details and chemical features that cannot be observed from fossil specimens embedded in amber. Hence, despite their excellent preservation, we do not want to assign the new fossils to any extant species, and we also refrain from assigning them to the previously described Chaenothecopsis bitterfeldensis Rikkinen \& Poinar. However, the four extant species and the three fossils are obviously closely related and most probably belong to the same lineage since $C$. bitterfeldensis resembles $C$. proliferatus and the two newly discovered fossils in ecology and spore type (Rikkinen \& Poinar 2000).

The morphological similarities between $C$. proliferatus and the proliferating fossil from Bitterfeld amber are especially striking. The only obvious difference is in the size of the fruiting bodies, with the preserved ascocarps of the fossil being distinctly smaller than typical ascocarps of $C$. proliferatus. Both fungi have relatively slender, commonly branched and proliferating fruiting bodies. The shape and general appearance of the capitula of young fruiting bodies are also identical. The stipes of both fungi are lined by a net of arching and horizontal hyphae (compare Fig. 2a, c and Fig. 7d, e), and these hyphae extend to the epithecium in a similar way. In both fungi, the one-septate and smooth (or minutely punctate) ascospores accumulate on top of the epithecium. All these morphological features together indicate that the fossil is closely related to $C$. proliferatus. 

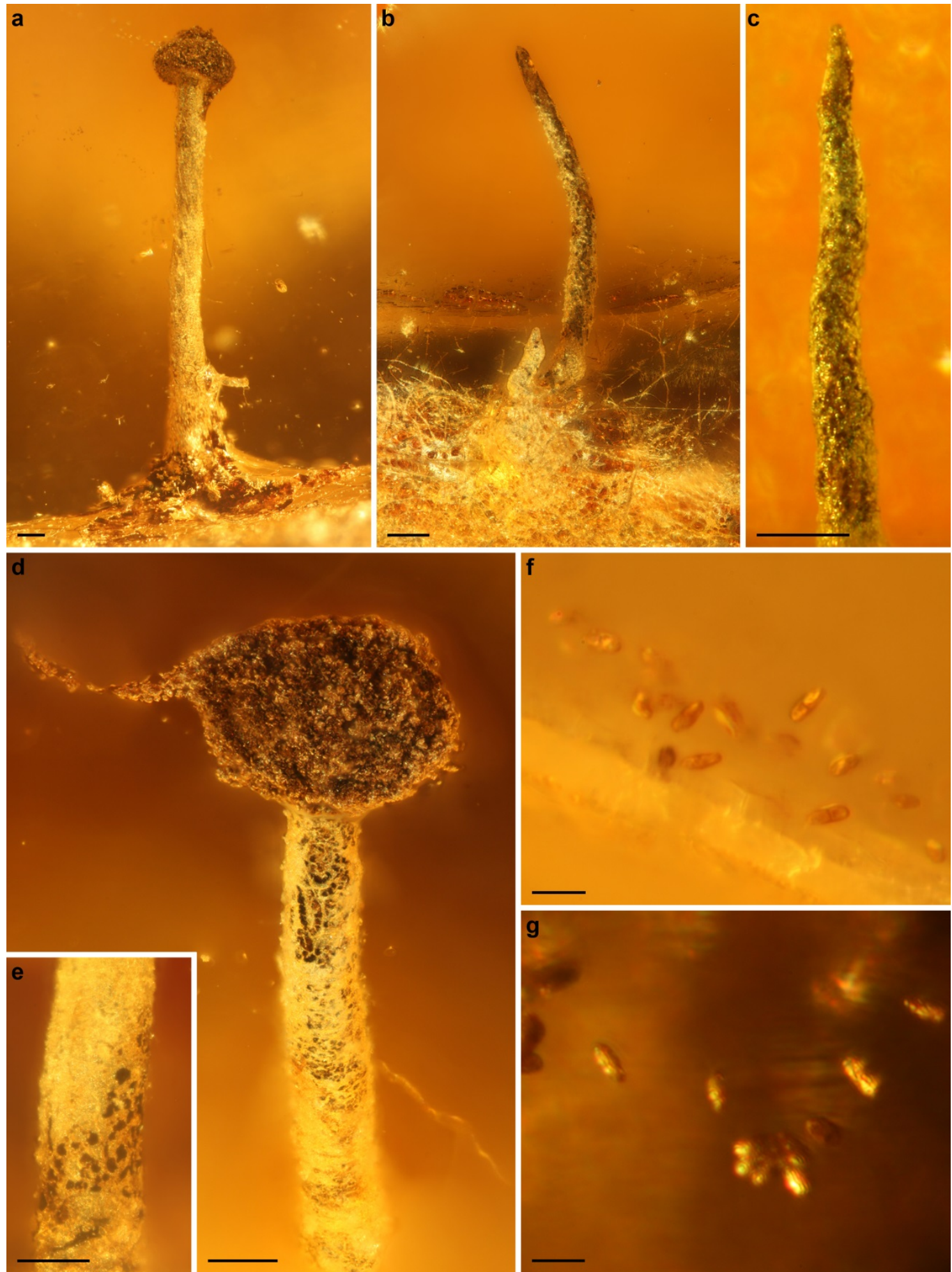

Fig. 9 Ascomata and anatomical details of the fossil Chaenothecopsis from Baltic amber (GZG.BST.27286). a Mature ascoma. b Young, developing ascoma and fungal mycelium. c Tip of developing ascoma (compare with Fig. 25 in Rikkinen 2003a). d Capitulum and upper part of stipe; note the accumulated ascospores. Numerous abscised spores extend into the amber matrix in the upper left. e Closer view of stipe surface. f-g Detached ascospores. Scale bars: $100 \mu \mathrm{m}$ (a-e) and $10 \mu \mathrm{m}$ (f and g). 
The epithecium of Chaenothecopsis proliferatus is, in places, covered by a thin layer of small crystals. These blade-like structures are typically 1-3 $\mu \mathrm{m}$ long and sharply pointed at both ends (Fig. 4d). While some crystals seem to be partly embedded in the extracellular matrix of fungal hyphae, most appear external. Similar crystals are also present on the upper section of the stipe (Fig. 4b). In their general appearance, the crystals somewhat resemble the needle-like calcium oxalate crystals that cover the hyphal surfaces of some fungi. Such crystals are formed when oxalic acid secreted by the fungus combines with external calcium to produce calcium oxalate (Dutton and Evans 1996). However, only carbon and oxygen were detected from the epithecium surface of $C$. proliferatus in EDX analyses.

\section{Occurrence and ecological role of proliferating ascocarps}

The ascomata of many species of Mycocaliciales can occasionally have a capitulum in which the apothecial disk is divided into several distinct regions or lobes. Asci tend to first mature in the central sections of the hymenia and when more asci mature, the hymenium expands and the capitulum surface become increasingly convex. Irregularities in ascus production can easily lead to the development of several hymenial convexities or lobes per capitulum. Many Chaenothecopsis species can also occasionally produce branched ascocarps, and these structures appear to be especially common in resinicolous species with long and slender stipes, such as $C$. diabolica and C. oregana. However, ascocarp braching is not confined only to resinicolous species, but also occurs in some lichen-associated and lignicolous species such as $C$. haematopus Tibell and C. savonica (Räsänen) Tibell, which typically grow on lignum in shaded microhabitats. Branching also occurs in some species of Mycocalicium Vain., Phaeocalicium A.F.W. Schmidt and Stenocybe Nyl. ex Körb. For example, Stenocybe pullatula (Ach.) Stein can produce several capitula from the same stipe, with the youngest at the tip and the older, senescing capitula appearing as a whorl directly below. This species produces ascocarps on the bark of Alnus species.

In the resinicolous Chaenothecopsis nigripunctata branching mainly occurs very close to the tip of the stipe, with each short branch forming a separate apothecial head. Profuse branching often leads to the development of compound capitula, consisting of up to twelve partially contiguous apothecial heads (Rikkinen 2003b). Mycocalicium sequoiae also produces clusters of apothecial heads on a common stipe (Bonar 1971). However, in this species the stipes tend to branch lower and hence have longer branches and less confluent apothecial heads than in $C$. nigripunctata. Also the related $C$. montana can produce branched ascocarps, but more rarely than the other two species (Tuovila et al. 2011b).

While the ascomata of $C$. nigripunctata and its closest relatives mainly branch from 
the upper part of the stipe, their ascocarps do not usually form multi-layered groups via branching and proliferation through the hymenium in the way exhibited by the proliferating fossil from Bitterfeld amber and many specimens of $C$. proliferatus. However, similar branching is quite common in the resinicolous C. dolichocephala and C. sitchensis, both of which usually have very narrow and long stipes. This shared morphology might represent an adaptation to growing near active resin flows: the perennial ascocarps can effectively rejuvenate in situations where they happen to be partly submerged in fresh exudate. All three species commonly live on cankers and wounds which exude resin over extended periods.

It seems unlikely that even resinicolous Chaenothecopsis species could rejuvenate after being rapidly and completely submerged in fresh sticky resin. Even the fossil specimens had first produced fruiting bodies on hardened resin and then had subsequently been covered by a thick layer of fresh exudate (Rikkinen and Poinar 2000). This raises the question of what then triggers the proliferation in partly submerged ascocarps and those ascocarps only growing close to fresh resin. It has been shown that some fungi react to the volatile compounds produced by other fungi when competing for resources (Evans et al. 2008). It is also known that fresh resin contains high levels of volatile compounds, mainly monoterpenes and sesquiterpenes, when compared to older, semisolid exudate, and that the hardening of resin is directly related to the loss of such compounds (e.g. Langenheim 2003; Ragazzi and Schmidt 2011). An ability to detect and respond to the presence of volatile resin compounds in the environment would give the Chaenothecopsis species time to prepare for a potential burial in freshly exuding resin. It seems feasible that some resinicolous fungi could begin to branch when the concentration of volatile resin compounds in their typically sheltered microenvironment is sufficiently high as to indicate that a fresh resin flow may be imminent. In other fungi the differentiation of fruiting bodies is commonly triggered by the perception of some signal of environmental conditions, such as light, pH, oxygen etc. (Busch and Braus 2007).

The hyphae of extant resinicolous fungi commonly penetrate and grow into semisolid resin. Evidence of inward growth of fungal hyphae is also preserved in numerous worldwide amber fossils since the Paleocene (personal observation), but no evidence of a similar capability has yet been found prior to the Cretaceous-Paleogene boundary. Cretaceous amber pieces from several different deposits may contain abundant filaments that grew from the resin surface into liquid resin, but all of these have been identified as filamentous prokaryotes (see Schmidt and Schäfer 2005; Schmidt et al. 2006; Girard et al. 2009a, b; Beimforde and Schmidt 2011), not as fungal hyphae. This suggests that this special niche was either occupied by prokaryotes in the Mesozoic or that Chaenothecopsis species (if already existent) and other ecologically similar fungi did not yet exploit resin substrates. 


\section{Conclusions}

Fossil evidence of inward growth of fungal hyphae into plant exudates has not been identified from Mesozoic ambers, suggesting a relatively late occupation of such substrates by ascomycetes. Even so, resinicolous Chaenothecopsis species were well adapted to their niche by the Eocene and the ecology and morphology of these fungi has since remained unchanged. The Oligocene fossil had produced proliferating ascomata identical to those of the newly described species from China and its extant relatives. This morphology may represent an adaptation to life near exuding resin: the proliferating ascomata can effectively rejuvenate if partly overrun by fresh exudate. While many extant Chaenothecopsis species live on lichens and/or green algae, the fossils and the sporadic occurrence of resinicolous taxa in several distantly related extant lineages suggests that the early diversification of Mycocaliciales may have occurred on plant substrates.

\section{Acknowledgements}

The field work in Hunan Province was done in cooperation with the Forestry Department of Hunan Province and its Forest Botanical Garden, and the Department of Biosciences (formerly Department of Ecology and Systematics), and the Botanical Museum, University of Helsinki. We thank Timo Koponen who's Academy of Finland project (no 44475) made the field work possible. Jörg Wunderlich (Hirschberg and der Weinstraße, Germany) kindly provided an amber piece of his collection for this study and Hans Werner Hoffeins (Hamburg) embedded the Baltic amber piece in polyester resin. We are grateful to Eugenio Ragazzi (Padova) for discussion about resin chemistry, to Dorothea Hause-Reitner (Göttingen) for assistance with field emission microscopy and to Leyla J. Seyfullah (Göttingen) for comments on the manuscript. Dr. Marie L. Davey (University of Oslo) provided indispensable help with sequencing difficult samples and advice on the molecular work. The work of H.T. was supported by research grants from the Jenny and Antti Wihuri Foundation and Ella and Georg Ehrnrooth Foundation. This is publication number 92 from the Courant Research Centre Geobiology that is funded by the German Initiative of Excellence. 


\section{References}

Beimforde C, Schmidt AR (2011) Microbes in resinous habitats: a compilation from modern and fossil resins. Lecture Notes in Earth Sciences 131:391-407

Beimforde C, Schäfer N, Dörfelt H, Nascimbene PC, Singh H, Heinrichs J, Reitner J, Rana RS \& Schmidt AR (2011) Ectomycorrhizas from a Lower Eocene angiosperm forest. New Phytol 192:988-996

Blumenstengel H (2004) Zur Palynologie und Stratigraphie der Bitterfelder Bernsteinvorkommen (Tertiär). Exkursionsführer und Veröffentlichungen der Deutschen Gesellschaft für Geowissenschaften 224:17

Bonar L (1971) A new Mycocalicium on scarred Sequoia in California. Madranõ 21:6269

Busch S, Braus GH (2007) How to build a fungal fruit body: from uniform cells to specialized tissue. Mol Microbiol 64:873-876

Castresana J (2000) Selection of conserved blocks from multiple alignments for their use in phylogenetic analysis. Mol Biol Evol 17:540-552

Drummond AJ, Ashton B, Buxton S, Cheung M, Cooper A, Duran C, Field M, et al (2011). Geneious v5.4. Retrieved from www.geneious.com 1 May 2011

Dunlop J (2010) Bitterfeld amber. In: Penney D (ed) Biodiversity of Fossils in Amber. Siri Scientific Press, Manchester, pp 57-68

Dutton MV, Evans CS (1996) Oxalate production by fungi: its role in pathogenicity and ecology in the soil environment. Can J Microbiol 42:881-895

Evans JA, Eyre CA, Rogers HJ, Boddy L, Müller CT (2008) Changes in volatile production during interspecific interactions between four wood rotting fungi growing in artificial media. Fungal Ecol 1:57-68

Gardes M, Bruns TD (1993) ITS primers with enhanced specificity for basidiomycetes application to the identification of mycorrhizae and rusts. Mol Ecol 2:113-118

Geiser DM, Gueidan C, Miadlikowska J, Lutzoni F, Hofstetter V, Fraker E, Schoch CL, et al. (2006) Eurotiomycetidae and Chaetothyriomycetidae. Mycologia 98:10531064

Girard V, Breton G, Brient L, Neraudeau D (2009a) Sheathed prokaryotic filaments, major components of mid-Cretaceous French amber microcoenoses. J Paleolimnol 42:437-447

Girard V, Schmidt AR, Struwe S, Perrichot V, Breton G, Néraudeau D (2009b) Taphonomy and palaeoecology of mid-Cretaceous amber-preserved microorganisms from southwestern France. In: Perrichot V, Néraudeau D (eds) Cretaceous ambers from southwestern France: geology, taphonomy, and palaeontology. Geodiversitas 31:153-162 
Hoffeins HW (2001) On the preparation and conservation of amber inclusions in artificial resin. Pol J Entomology 70:215-219

Katoh K, Toh H (2008) Recent developments in the MAFFT multiple sequence alignment program. Brief Bioinforma 92:86-98

James TY, Kauff F, Schoch CL et al. (2006) Reconstructing the early evolution of Fungi using a six-gene phylogeny. Nature 443:818-822

Knuth G, Koch Th, Rappsilber I, Volland L (2002) Concerning amber in the Bitterfeld region -geologic and genetic aspects. Hallesches Jahrb Geowiss 24:35-46

Koponen T, Enroth J, Fang YM, Huttunen S, Hyvönen J, Ignatov M, Juslén A, Lai MJ, Piippo S, Potemkin A, Rao PC (2000) Bryophyte flora of Hunan Province, China, 1. Bryophytes from Mangshan Nature Reserve and Wulingyuan Global Cultural Heritage Area. Ann. Bot. Fennici 37:11-39

Koponen T, Cao T, Huttunen S, Hyvönen J, Juslén A, Peng C, Piippo S, Rao PC, Vána J, Virtanen V (2004) Bryophyte Flora of Hunan Province, China, 3: Bryophytes from Taoyuandong and Yankou Nature Reserves and: Badagongshan and Hupingshan National Nature Reserves, with additions to floras of Mangshan Nature Reserve and Wulingyuan Global Cultural Heritage Area. Acta Bot Fennica 177:1-47

Kumar S, Skjæveland Å, Orr R, Enger P, Ruden T, Mevik BH, Burki F, et al. (2009) AIR: A batch-oriented web program package for construction of supermatrices ready for phylogenomic analyses. BMC Bioinforma 10:357

Langenheim, JH (2003) Plant resins: chemistry, evolution, ecology and ethnobotany. Timber Press, Portland.

Müller K, Müller J, Neinhuis C, Quandt D (2010) PhyDE - Phylogenetic Data Editor. www.phyde.de. Retrieved 15 October 2011

Pratibha J, Amandeep K, Shenoy BD, Bhat DJ (2011) Caliciopsis indica sp. nov. from India. Mycosphere 1:65-72

Posada D (2008) jModelTest: Phylogenetic Model Averaging. Mol Biol Evol 25:12531256

Ragazzi E, Schmidt AR (2011) Amber. In: Reitner J, Thiel V (eds) Encyclopedia of Geobiology. Spinger, Dordrecht, pp 24-36

Rehner S, Samuels GJ (1994) Taxonomy and phylogeny of Gliocladium analyzed from nuclear large subunits ribosomal DNA sequences. Mycol Res 98:625-634

Rikkinen J (1999) Two new species of resinicolous Chaenothecopsis (Mycocaliciaceae ) from western North America. Bryologist 102:366-369

Rikkinen J (2003a) Calicioid lichens and fungi in the forests and woodlands of western Oregon. Acta Bot Fennica 175:1-41

Rikkinen J (2003b) Chaenothecopsis nigripunctata, a remarkable new species of resinicolous Mycocaliciaceae from western North America. Mycologia, 95:98-103 
Rikkinen J, Poinar G (2000) A new species of resinicolous Chaenothecopsis (Mycocaliciaceae, Ascomycota)

from 20 million year old Bitterfeld amber, with remarks on the biology of resinicolous fungi. Mycol Res 104:7-15

Ronquist F, Huelsenbeck JP (2003) Bayesian phylogenetic inference under mixed models. Bioinforma 19:1572-1574

Schmidt AR, Dörfelt H (2007) Evidence of Cenozoic Matoniaceae from Baltic and Bitterfeld amber. Rev Palaeobot Palynol 144:145-156

Schmidt AR, Schäfer U (2005) Leptotrichites resinatus new genus and species, a fossil sheathed bacterium in alpine Cretaceous amber. J Paleontol 79:184-193

Schmidt AR, Jancke S, Lindquist EE, Ragazzi E, Roghi G., Nascimbene P, Schmidt K, Wappler T \& Grimaldi DA (2012) Arthropods in amber from the Triassic Period. PNAS 109:14796-14801

Schmidt AR, Ragazzi E, Coppellotti O, Roghi G (2006) A microworld in Triassic amber. Nature 444:835

Selva SB, Tibell L (1999) Lichenized and non-lichenized calicioid fungi from North America. Bryologist 102:377-397

Standke, G. (1998) Die Tertiärprofile der Samländischen Bernsteinküste bei Rauschen. Schriftenreihe für Geowissenschaften 7: 93-133.

Standke G (2008) Bitterfelder Bernstein gleich Baltischer Bernstein? - Eine geologische Raum-Zeit-Betrachtung und genetische Schlußfolgerungen. In: Rascher J, Wimmer R, Krumbiegel G, Schmiedel S (eds) Bitterfelder Bernstein versus Baltischer Bernstein - Hypothesen, Fakten, Fragen. Exkursionsführer und Veröffentlichungen der Deutschen Gesellschaft für Geowissenschaften 236:11-33

Tibell L, Titov A (1995) Species of Chaenothecopsis and Mycocalicium (Caliciales) on exudate. Bryologist 98:550-560

Tibell L, Vinuesa M (2005) Chaenothecopsis in a molecular phylogeny based on nuclear rDNA ITS and LSU sequences. Taxon 54:427-442

Titov A (2001) Further notes on calicioid lichens and fungi from the Gongga Mountains (Sichuan, China). Lichenologist 33:303-314

Titov A, Tibell L (1993) Chaenothecopsis in the Russian Far East. Nord J Bot 13:313329

Titov A (2006) Mikokalizievye griby (porjadok Mycocaliciales) Golarktiki [Mycocalicioid fungi (the order Mycocaliciales) of Holarctic]. KMK Scientific Press, Moskva

Tuovila H, Cobbinah JR, Rikkinen J (2011) Chaenothecopsis khayensis, a new resinicolous calicioid fungus on African mahogany. Mycologia 103:610-615

Tuovila H, Larsson PER, Rikkinen J (2011) Three resinicolous North American species 
of Mycocaliciales in Europe with a re-evaluation of Chaenothecopsis oregana Rikkinen. Karstenia 51:37-49

Vilgalys R, Hester M (1990) Rapid genetic identification and mapping of enzymatically amplified ribosomal DNA from several Cryptococcus species. J Bacteriol 172:42384246

Vinuesa M, Sanchez-Puelles JM, Tibell L (2001) Intraspecific variation in Mycocalicium subtile (Mycocaliciaceae) elucidated by morphology and the sequences of the ITS15.8S-ITS2 region of rDNA. Mycol Res 105:323-330

Wang Z, Binder M, Hibbett DS (2005) Life history and systematics of the aquatic discomycete Mitrula (Helotiales, Ascomycota) based on cultural, morphological, and molecular studies. Am J Bot 92:1565-1574

Weitschat W (1997) Bitterfelder Bernstein-ein eozäner Bernstein auf miozäner Lagerstätte. Metalla 66:71-84

White TJ, Bruns TD, Lee S, Taylor JW (1990) Amplification and direct sequencing of fungal ribosomal RNA genes for phylogenetics. In: Innis MA, Gelfand DH, Sninsky JJ, White TJ (Eds) CR Protocols: A Guide to Methods and Applications. Academic Press, New York, pp. 312-322

Zwickl DJ (2006) Genetic algorithm approaches for the phylogenetic analysis of large biological sequence datasets under the maximum likelihood criterion. Dissertation, The University of Texas 


\section{Appendix 3}

Sadowski E-M, Beimforde C, Gube M, Rikkinen J, Singh H, Seyfullah LJ, Heinrichs J, Nascimbene PC, Reitner J, Schmidt AR, (2012). The anamorphic genus Monotosporella (Ascomycota) from Eocene amber and from modern Agathis resin. Fungal Biology 116, 1099-1110.

Impact factor of Fungal Biology 2011: 1.429, according to Journal Citation Reports 


\title{
The anamorphic genus Monotosporella (Ascomycota) from Eocene amber and from modern Agathis resin
}

\author{
Eva-Maria Sadowski ${ }^{\mathrm{a}}$, Christina Beimforde ${ }^{\mathrm{a}}$, Matthias Gube ${ }^{\mathrm{b}}$, Jouko Rikkinen ${ }^{\mathrm{c}}$, \\ Hukam Singh $^{\text {d }}$, Leyla J. Seyfullah ${ }^{\mathrm{a}}$, Jochen Heinrichs ${ }^{\mathrm{e}}$, Paul C. Nascimbene ${ }^{\mathrm{f}}$, Joachim \\ Reitner $^{\mathrm{a}}$ and Alexander R. Schmidt ${ }^{\mathrm{a}, *}$

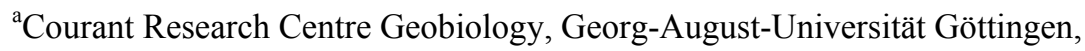 \\ Goldschmidtstraße 3, 37077 Göttingen, Germany, ${ }^{b}$ Mikrobielle Phytopathologie, Friedrich-Schiller- \\ Universität Jena, Neugasse 25, 07743 Jena, Germany, ${ }^{c}$ Department of Biosciences, P.O. Box 65, FIN- \\ 00014 University of Helsinki, Finland, ${ }^{\mathrm{d} B i r b a l}$ Sahni Institute of Palaeobotany, 53 University Road, \\ Lucknow 226007, India, ${ }^{\mathrm{e}}$ Albrecht-von-Haller-Institut für Pflanzenwissenschaften, \\ Abteilung Systematische Botanik, Georg-August-Universität Göttingen, Untere Karspüle 2, 37073 \\ Göttingen, Germany, ${ }^{\mathrm{f}}$ Division of Invertebrate Zoology, American Museum of Natural History, 79th \\ Street at Central Park West, New York, NY 10024, USA \\ Corresponding author Alexander Schmidt \\ (alexander.schmidt@geo.uni-goettingen.de (A. R. Schmidt)
}




\begin{abstract}
The anamorphic fungal genus Monotosporella (Ascomycota, Sordariomycetes) has been recovered from a piece of Early Eocene Indian amber, as well as from the surface of extant resin flows in New Caledonia. The fossil fungus was obtained from the Tarkeshwar Lignite Mine of Gujarat State, western India, and was part of the biota of an early tropical angiosperm rainforest. The amber inclusion represents the second fossil record of Sordariomycetes, as well as the first fossil of its particular order (either Savoryellales or Chaetosphaeriales). The fossil fungus is distinguished from extant representatives by possessing both short conidiophores and small two-septate pyriform conidia, and is described as Monotosporella doerfeltii sp. nov. Inside the amber, the anamorph is attached to its substrate, which is likely the degraded thallus of a cladoniform lichen. The extant New Caledonian species is assigned to Monotosporella setosa. It was found growing on semi-solidified resin flows of Agathis ovata (Araucariaceae), and is the first record of Monotosporella from modern resin substrates.
\end{abstract}

Keywords: Araucariaceae; Ascotaiwania; fossil fungi; lichens; India; New Caledonia. 


\section{Introduction}

Amber (fossil tree resin) preserves its inclusions in submicroscopic detail, including cells and organelles, even serving as a medium for the preservation of ephemeral structures such as the reproductive anatomy of fungi (e.g., Hibbett et al. 1997; Schmidt et al. 2006). During the last two decades, a plethora of fungi has been described from Mesozoic and Cenozoic resins (e.g., Rikkinen and Poinar 2000, 2008; Rikkinen et al. 2003; Schmidt et al. 2007, 2010a), and new preparation methods now allow the same detailed morphological investigation of the fossils as is possible with modern representatives (Dörfelt et al. 2003; Beimforde et al. 2011). Many morphologically determinable amber inclusions represent anamorphic stages of filamentous ascomycetes (e.g., Thomas and Poinar 1988; Dörfelt and Schmidt 2005, 2007). Thus far, very few fruiting bodies of Ascomycota (Caspary and Klebs 1906; Mägdefrau 1957; Rikkinen and Poinar 2000; Rossi et al. 2005) and Agaricomycetes (Poinar and Singer 1990; Hibbett et al. 1997, 2003; Poinar and Buckley 2007; Schmidt et al. 2010b) have been reported from mid-Cretaceous to Miocene ambers.

Apart from acting as a preservation medium, tree resins also serve as habitat for particular fungal taxa (Beimforde and Schmidt 2011). For example, some extant species of the genera Chaenothecopsis and Mycocalicium (Mycocaliciomycetidae, Mycocaliciales) are resinicolous (see Tibell and Titov 1995). Rikkinen (1999, 2003) discovered several modern species from conifer resins in the temperate rain forests of western North America, as well as an extinct species, Chaenothecopsis bitterfeldensis, in 24 million-year-old amber from Germany (Rikkinen and Poinar 2000). Meanwhile, some extant species live specifically on angiosperm exudates in temperate or tropical forests (Tibell and Titov 1995; Tuovila et al. 2011a, 2011b). Because of their habitat specificity, it has been suggested that these fungi use liquid resin as their sole nutrient source (Rikkinen and Poinar 2000).

Here, we report on an apparently lichenicolous fossil species of the anamorphic genus Monotosporella (Ascomycota) from an Early Eocene tropical angiosperm forest. We also describe an extant resinicolous taxon of the same genus from the exudate of Agathis ovata (C. Moore ex Vieill.) Warb (Araucariaceae) in New Caledonia. The fossil is enclosed in a piece of 52 million-year-old Indian amber produced by a tropical angiosperm tree of the family Dipterocarpaceae (Rust et al. 2010). Apart from the huge number and diversity of arthropod inclusions, this amber deposit has already yielded the first fossil angiosperm ectomycorrhizae (Beimforde et al. 2011). The fossil Monotosporella differs from extant species in some morphological attributes. The extant taxon from New Caledonia is assigned to M. setosa (Berk. and M.A. Curtis) S. 
Hughes, but no Monotosporella species (including M. setosa) have been previously reported from resin substrates.

\section{Material and methods}

\section{Amber specimen}

Amber piece AMNH Tad-39 was found in situ in the Tarkeshwar Lignite Mine of Gujarat State, western India. The amber-bearing strata are part of the Cambay Formation, which has been assigned to the Ypresian (52 million years old, Early Eocene) based on shark teeth, dinoflagellates and the index foraminiferan Nummulites burdigalensis burdigalensis. The deposition is interpreted as shallow chenier marine sediments (Rust et al. 2010). The amber piece contains an elongate sulcate structure (Fig. 1A) that serves as the substrate of a conidial fungus. A root tip with root hairs is located close to this structure. Arthropod fragments and faeces, as well as two angiosperm seeds, are attached to the surface of the elongate structure.

The original $1.2 \times 0.9 \times 0.4 \mathrm{~cm}$ amber piece was ground and polished manually using a series of wet silicon carbide papers [grit from FEPA P 600-4000 (25.8 $\mu \mathrm{m}$ to 5 $\mu \mathrm{m}$ particle size), firm Struers] and examined under incident (Carl Zeiss Stemi 2000) and transmitted light microscopes (Carl Zeiss AxioScope A1) equipped with Canon 450D digital cameras. Sometimes incident and transmitted light were used simultaneously. The images of Fig. 1A-D, 1F, and those of Fig. 2, were obtained from several focal planes using the software package HeliconFocus 5.0 to enable a better illustration of the three-dimensional inclusions. For permanent preparation, the piece of amber was fully embedded in a high-grade epoxy (Buehler Epoxicure) under vacuum (see Nascimbene and Silverstein 2001 for protocols). After curing, the resultant epoxy plugs surrounding each sample were cut and polished to create clear flat surfaces close to the amber and its inclusions. The amber piece is currently housed in the amber collection of the Division of Invertebrate Zoology, American Museum of Natural History, New York. Indian amber pieces will ultimately be deposited in the amber collection of the INSA (Indian National Science Academy) Project Geology at the University of Lucknow, India.

\section{Extant specimens}

Semi-solidified resin flows with fungi were collected in 2005 and in 2011 from the base of tree trunks of Agathis ovata (Araucariaceae) in the southern province of New Caledonia (Fig. 3). The sampling site is in an area of maquis scrubland that occurs on 
ultramafic rocks along the road RP 3 about $5 \mathrm{~km}$ west of Yate in south-eastern New Caledonia (2210'03.63" S latitude; 16654'10.15" E longitude, elevation $411 \mathrm{~m}$ ).

Light microscopy and stacking of single focal planes were performed as earlier described for the fossil. The images of Fig. 4 A-C were obtained from several focal planes. For scanning electron microscopy, resin fragments with the anamorph were placed on a carbon-covered SEM-mount, sputtered with gold/palladium (2 x 120 seconds at $20 \mathrm{~mA}, 10 \mathrm{~nm}$ coat thickness) using an Automatic Sputter Coater (Canemco Inc.), and examined under a field emission scanning-electron microscope (Carl Zeiss LEO 1530).

The resin flows with fungi are housed in the Geoscientific Collections of the Georg August University Göttingen (collection number GZG.PB.5003; publication number 001611).

\section{Results}

\section{Fossil anamorph in Indian amber}

The anamorphic fungus produced numerous conidiophores, which are arranged in groups or arise singly from the substrate (Figs 1A, C, F and 2). The conidiophores are straight or arcuate, pale brown to hyaline, and sometimes septate (Fig. 2). The length of the conidiophores (measured without conidia) ranges from 15 to $60 \mu \mathrm{m}$ (average 24.5 $\mu \mathrm{m}, \mathrm{n}=18$ ). Hyphal width is $4-5 \mu \mathrm{m}$ at the base of the conidiophore (average $4.8 \mu \mathrm{m}$, $\mathrm{n}=17$ ) and $2-5 \mu \mathrm{m}$ at the apex (average $4.4 \mu \mathrm{m}, \mathrm{n}=17$ ). Two exceptionally long conidiophores reach about $60 \mu \mathrm{m}$ in length and seem to have developed as a result of percurrent proliferation, as indicated by the remains of aborted conidia (Fig. 2B, D), and thus were excluded from the calculation of the mean value of measurements above. The terminal conidiogenous cells are monoblastic and form pyriform conidia that arise singly at the apex (Fig. 2). The conidia are dark brown to black with hyaline cells at the base, 1-3 septate, usually two-septate (Fig. 2 E). Their length ranges from 17 to $28 \mu \mathrm{m}$ (average $21.7 \mu \mathrm{m}, \mathrm{n}=19$ ). They are 10 to $15 \mu \mathrm{m}$ thick in the broadest part (average 12.9 $\mu \mathrm{m}, \mathrm{n}=19$ ) and 2 to $5 \mu \mathrm{m}$ wide at the base (average $4.5 \mu \mathrm{m}, \mathrm{n}=19$ ). The hyphae extending from the base of the conidiophores have a width of 2-3.5 $\mu \mathrm{m}$ and taper distally (Fig. 2C). Their progression within the substrate is uncertain. Other hyphae found on the substrate are pale brown to hyaline with an average width of $2.5 \mu \mathrm{m}$ (Fig. $1 \mathrm{~B}$; see Discussion for their affinities).

The conidial fungus from Indian amber matches the features of the extant anamorphic genus Monotosporella. However, since it can be clearly distinguished from 
all extant species (see Discussion), we propose that the amber inclusion be treated as a new species.

Phylum Ascomycota Cavalier-Smith 1998

Class Sordariomycetes O. E. Eriksson et Winka 1997

Genus Monotosporella S. Hughes 1958

Monotosporella doerfeltii Sadowski, Beimforde, Gube et A. R. Schmidt sp. nov. (Figure 2)

MycoBank No.: MB800370

Etymology: The epithet honours Heinrich Dörfelt, mycologist and ecologist at Friedrich Schiller University Jena (Germany), a pioneer of extensive systematic studies on amber-preserved fungi.

Description: Colonies scattered, dark brown. Mycelium composed of brown to pale brown hyphae, 2-3.5 $\mu \mathrm{m}$ wide. Conidiophores arranged in clusters or singly, straight or arcuate, pale brown to hyaline, sometimes possessing one septum, 15-40 (-60) $\mu \mathrm{m}$ long, 2-5 $\mu \mathrm{m}$ wide at apex, 4-5 $\mu \mathrm{m}$ wide at base. Conidiogenous cells monoblastic, terminal. Conidia solitary, dark brown to black with hyaline cells at the base, pyriform, 1-3 septate, usually $2-$ septate, $17-28 \mu \mathrm{m} \times 10-15 \mu \mathrm{m}, 2-5 \mu \mathrm{m}$ wide at the base.

Diagnosis: The amber specimen of Monotosporella is distinct from extant species in possessing the combination of short conidiophores and two-septate, pyriform and relatively small conidia. Although some extant species show one of these characteristics, their combination is unique within the genus Monotosporella (see Table S1).

Type location: Tarkeshwar Lignite Mine of Gujarat State, western India $\left(21^{\circ} 21.400 \mathrm{~N}\right.$ latitude, $073^{\circ} 04.532 \mathrm{E}$ longitude).

Type material: American Museum of Natural History, New York, USA; collection number AMNH Tad-39. We consider all conidiophores inside this amber piece to be derived from a single mycelium, and thus to be parts of a single type specimen. Fig. 2E is the validating illustration in fulfilment of Article 38.2 of the ICBN (McNeill et al. 2006). 


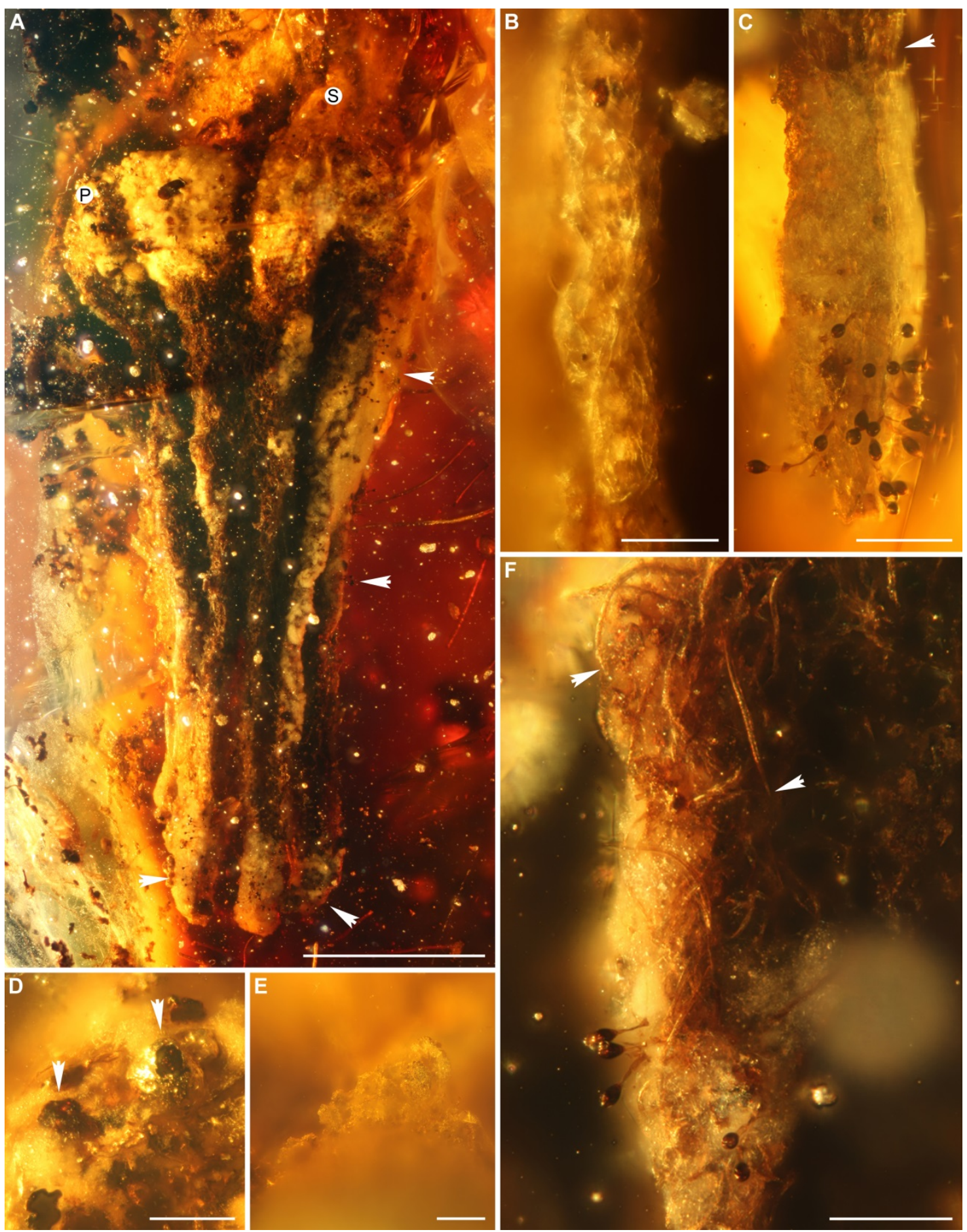

Figure 1. Substrate of Monotosporella doerfeltii sp. nov. from Indian amber (AMNH Tad-39). A Putative sulcate lichen podetium. The arrowheads indicate clusters of conidiophores of $M$. doerfeltii. The pycnidia $[\mathrm{P}]$ and soredia [S] are located in the upper part of the podetium. B Pale hyphae at the surface of the podetium. C Remains of the lichen's cortex with a cluster of conidiophores. The arrowhead indicates the subjacent hyphal layer. D Pycnidia with dark ostioles (arrowheads). E Soredia. F Dark hyphae of a probable further fungus growing on the lichen. The arrowheads indicate tapering hyphal tips. Scale bars = $1 \mathrm{~mm}$ in (A) and $100 \mu \mathrm{m}$ in $(\mathrm{B}-\mathrm{F})$. 


\section{Substrate of the fossil Monotosporella}

The substrate, to which all conidiophores of the fossil Monotosporella are attached, is about $7.2 \mathrm{~mm}$ long, and $0.9 \mathrm{~mm}$ to $2 \mathrm{~mm}$ wide. It is composed of fungal hyphae that form a somewhat fluffy mycelium. The whole structure is longitudinally ribbed. The distance between the furrows ranges from $200 \mu \mathrm{m}$ in the narrow part to $700 \mu \mathrm{m}$ in the broader part of the substrate (Fig. 1A). The surface of the mycelium is covered by light hyphae in the upper and basal parts of the substrate. Exposed along the deep furrows are a central cavity and dark-coloured hyphae with an average width of $6 \mu \mathrm{m}$ and apically tapered ends (Fig. 1F). Immersed dark structures protrude from the substrate in its upper and basal parts (Fig. 1A, D). They resemble globose pycnidia with dark ostiole-like pores at the top. The structures are clustered in groups, and two clearly visible examples have a size of $100 \mu \mathrm{m} \times 80 \mu \mathrm{m}$, and $90 \mu \mathrm{m} \times 75 \mu \mathrm{m}$, respectively. Scale-like microscopic bodies on the surface of the substrate range from $30 \mu \mathrm{m}$ to $100 \mu \mathrm{m}$ in size, and are reminiscent of soredia (typical morphological features of lichens) (Fig. 1A, E).

\section{Monotosporella from New Caledonian resin}

The fungus grows on the surface of resin flows that cover both bark and a leafy liverwort species belonging to the genus Bazzania, as well as a second liverwort species of the family Lepidoziaceae. The scattered mycelium on the resin's surface is largely restricted to small cavities within the resin, and consists of pale brown to black hyphae, and scattered upright conidiophores (Fig. 4A-C). The unbranched and septate conidiophores are often arranged in groups, and arise erectly or flexuously (Fig. 4G, H). They are dark brown to black in colour and measure $90 \mu \mathrm{m}$ to $220 \mu \mathrm{m}$ in length (average $135.9 \mu \mathrm{m}, \mathrm{n}=12$ ). At the base, the conidiophores are $9 \mu \mathrm{m}$ to $16 \mu \mathrm{m}$ wide (average $11 \mu \mathrm{m}, \mathrm{n}=8$ ), and taper towards the apex, which ranges from $3 \mu \mathrm{m}$ to $5 \mu \mathrm{m}$ wide (average $4.2 \mu \mathrm{m}, \mathrm{n}=11$ ). The conidiogenous cells are cylindrical to barrel-shaped, and form pyriform solitary conidia, which arise at the apex (Fig $4 \mathrm{H})$. The conidia are dark brown to black, while the lower cells are sometimes pale brown to hyaline and two-septate (Fig. 4D-F). They measure $31 \mu \mathrm{m}$ to $42 \mu \mathrm{m}$ in length (average $34.6 \mu \mathrm{m}$, $\mathrm{n}=17$ ). At the base, the width ranges between $3 \mu \mathrm{m}$ and $7 \mu \mathrm{m}$ (average $4.6 \mu \mathrm{m}, \mathrm{n}=16$ ). The broadest part of the conidia is $17 \mu \mathrm{m}$ to $26 \mu \mathrm{m}$ thick (average $22.5 \mu \mathrm{m}, \mathrm{n}=19$ ). Some conidiophores are elongated with slightly swollen bands in the distal parts, probably caused by repeated proliferation (Fig. 4D). Because of these features, this specimen is assigned to Monotosporella setosa. 

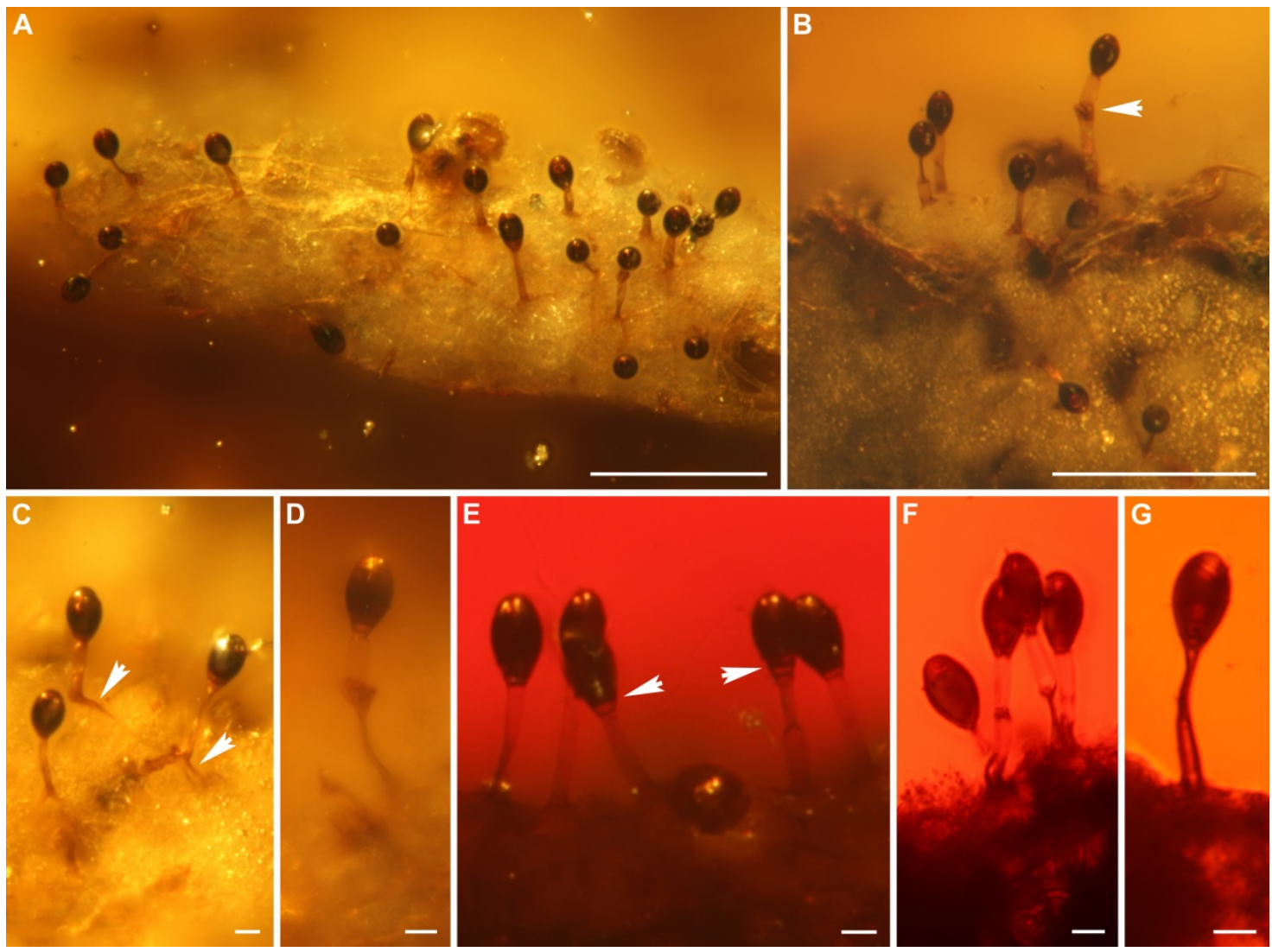

Figure 2. Monotosporella doerfeltii sp. nov. from Eocene Indian amber (AMNH Tad-39) under incident (A to D) and transmitted (E to G) light. Fig. 2E is the validating illustration to fulfil Article 38.2 of the ICBN (McNeill et al. 2006). A Conidiophores with conidia and adjacent hyphae of the mycelium. B Group of conidiophores with conidia. The arrowhead indicates the attachment site of a previous conidium. C Conidiophores with tapering adjacent hyphae, indicated by the arrowheads. D Single elongated conidiophore with a brown band indicating the attachment site of a previous conidium. E Group of conidiophores with conidia representing the holotype of Monotosporella doerfeltii. The arrowheads indicate the septation of the conidia. F Septate conidiophores. G Single conidiophore. Scale bars $=100 \mu \mathrm{m}$ in $(\mathrm{A}, \mathrm{B})$ and $10 \mu \mathrm{m}$ in $(\mathrm{C}-\mathrm{G})$.

\section{Discussion}

\section{The genus Monotosporella}

The genus Monotosporella S. Hughes 1958 is distributed worldwide (e.g., Sivichai et al. 1998; Raja et al. 2007). It is usually found growing on decaying wood submerged in freshwater (Sivichai et al. 1998; Tsui et al. 2001), but has also been reported from woody plants outside of aquatic habitats (Rao and de Hoog 1986; Raja et al. 2007).

Monotosporella, with $M$. setosa as its type species, was established to replace Monosporella S. Hughes 1953, a junior homonym to Monosporella Keilin 1920, nom illeg. (Saccharomycetes). Ellis (1959) regarded Monotosporella as a junior synonym for Brachysporiella Batista 1952, a genus with short lateral branches at the apex of the 
conidiophores. These branches were typically not found on Monotosporella, or only rarely found in reexamination (Matsushima 1975), and thus referred to as "rare abnormalities" (Hughes 1979). Here, we follow Hughes (1958) in treating Monotosporella as distinct from Brachysporiella, since lateral branches have not been described in any of the recently published extant Monotosporella species.
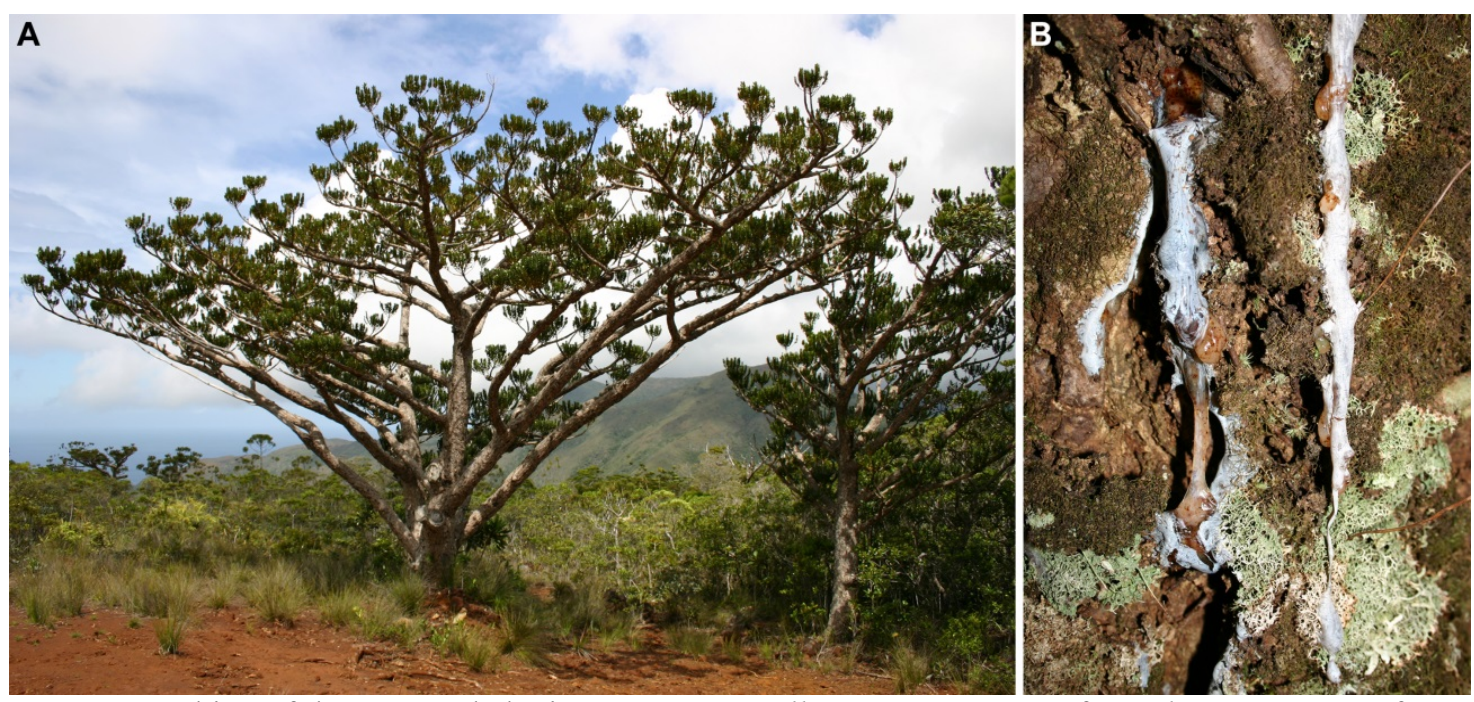

Figure 3. Habitat of the New Caledonian Monotosporella setosa. A Trees of Agathis ovata west of Yaté. B Resin flows at the tree trunk as microhabitat.

As listed by Index Fungorum (www.indexfungorum.org), nine species have been described within Monotosporella. Since then, several species have been transferred to other genera (based in part on details of their teleomorph states). Both M. setiformis (Wallr. 1833) S. Hughes 1958 and M. sphaerocephala (Berk. et Br. 1859) S. Hughes 1958 were transferred into Acrogenospora Ellis 1971 (teleomorph Farlowiella, Pleosporales), due to the lack of septation of the conidia (Ellis 1971, 1976). Monotosporella tuberculata Gönczöl 1976 was transferred to Tumularia tuberculata (Gönczöl) Descals et Marvanová (Marvanová and Descals 1987), since it has conidia with 4-6 node-like protuberances. However, subsequent publications tend to follow Gönczöl (1976) in the use of M. tuberculata (e.g., Schoch et al. 2009). Monotosporella tuberculata was revealed as an anamorph of Melanommataceae, Pleosporales (Zhang et al. 2009). Monotosporella microaquatica (Tubaki 1957) Nilsson 1964 was initially ascribed as Dactylella microaquatica Tubaki 1957, but was illustrated and redescribed as Endophragmia microaquatica (Tubaki 1957) Matsush. 1975. While Dactylella anamorphs are typical for Orbiliaceae, Endophragmia (syn.: Phragmocephala E.W. Mason and S. Hughes 1951) is currently considered incertae sedis within Pezizomycotina, and no teleomorph stages are known. Therefore, and also due to the lack of molecular analyses of this species, an assignment to Monotosporella cannot yet be excluded. 
The phylogenetic position of the genus Monotosporella is not fully established. In the descriptions of Monotosporella e.g. by Hughes (1953), the genus was regarded as belonging to the Hyphomycetes within the Fungi imperfecti. With the discovery of the teleomorphs - Ascotaiwania mitriformis (Ranghoo and Hyde 1998) and Ascotaiwania sawada (Sivichai et al. 1998) - Monotosporella was placed in the family Annulatascaceae within the Sordariales.

This family placement was analyzed by Ranghoo et al. (1999a), who confirmed the monophyletic relationship between Ascotaiwania and Monotosporella. However, their results also indicated that the genus Ascotaiwania is unrelated to the Annulatascaceae. Evidence for the exclusion of Ascotaiwania and Monotosporella from the Annulatascaceae was also given by Campbell and Shearer (2004), based on the phylogenetic analysis of $28 \mathrm{~S}$ rDNA. These authors showed that both genera form a monophyletic group, which is widely separated from the Annulatascaceae. Other authors (Sivanesan and Chang 1992; Fallah et al. 1999) claimed that Ascotaiwania belongs to the Amphisphaeriaceae of the Xylariales. Réblová and Seifert (2004) indicate a close relationships between Ascotaiwania and the genera Conioscypha, Conioscyphascus and Carpoligna outside of Xylariales, but could not clarify the position within Sordariomycetes. In subsequent analyses (Arzanlou et al. 2007; Réblová and Seifert 2011), Pleurothecium and Sterigmatobotrys were also assigned to that group. All this implies relationships with Chaetosphaeriales. Recently, Boonyuen et al. (2011) established a clade of Ascothailandia, Savoryella and Ascotaiwania, including Monotosporella setosa, and raised the order of Savoryellales to accommodate them. Although Ascotaiwania was not in all analyses revealed to be monophyletic, the anamorph-possessing group of $A$. hughesii and $M$. setosa remained stable in all analyses. The genera that are considered to be relatedto Ascotaiwania by Réblova and Seifert $(2004,2011)$ were not treated in this analysis. Thus, the relations between Savoryellales and Chaetosphaeriales remain elusive to date. In any case, all these fungi belong to the monophyletic class Sordariomycetes as delimited in Hibbett et al. (2007).

\section{Comparison of the fossil to extant taxa}

The genus Monotosporella comprises saprophytic fungi with solitary septate conidiophores that proliferate through the conidial scar (Hughes 1953). As a result, the length of the conidiophores increases by successive proliferation (Hughes 1953). The solitary conidia arise at the apex and are spheroid to pyriform and two-septate. According to Ellis (1959), the lower cells of the conidia are much paler than the dark brown or black uppermost cells. The mycelium is described as "immersed in the substratum," with "pale brown to brown" hyphae and septate branches (Ellis 1959). 
For the fossil specimen, the shape and septation of the conidia, as well as the characteristics of the conidiophores, conform to the characters provided in the original diagnosis of Monosporella by Hughes (1953). Unfortunately, it is not possible to analyze percurrent proliferation in the fossil specimen, since the character of the conidiogenous cells, i.e. the wall layers or the secession itself, cannot be observed. However, the two elongated conidiophores of the amber inclusion (Fig. 2B, D) seem to have been produced via successive proliferation, and they even have brown bands, which we interpret as attachment sites of previous conidia. Several other extant anamorph genera of the Ascomycota also show partial similarities when compared with the fossil specimen, such as Endophragmiella, Phragmocephala and Bactrodesmium (Ellis 1971; Holubová-Jechová 1972, 1986; Hughes 1979; Palm and Stewart 1982; Kirk 1985). All these are also characterised by rhexolytic conidium succession and a somewhat similar morphology. However, we did not observe sporodochia or fasciculate conidiophores. Also, conidia with exclusively basal septation and without darker bands, which are borne on relatively long conidiophores, are not seen in combination in these genera, but are quite typical for Monotosporella. Some fungal palynomorphs, like Brachysporisporites, might also have relationships to Monotosporella (e.g. Ediger 1981). However, even though such palynomorphs may be preserved in amber (Antoine et al. 2006), a concise allocation of these to extant or to better-preserved fossil fungi, such as our specimen, is hard to achieve, due to the very limited morphological characters preserved. For a detailed comparison of the amber inclusion with extant Monotosporella species, all seven presently accepted extant taxa are used (see Table S1), as well as the Monotosporella-like anamorphs of Ascotaiwania, and the possibly related Dactylella microaquatica.

Extant Monotosporella species are distinguished according to the size of the conidiophores and the conidia, the shape and the septation of the conidia, and the presence or absence of conidiogenous cells with lobe-like swellings (see key in Ranghoo et al. 1999b and also Hughes 1978; Yanna and Hyde 2002). Further criteria are found in the size and shape of the conidiogenous cells, but since these cells cannot be directly observed in the fossil specimen, these characteristics are excluded from our comparison. The synopsis of the main characters of extant Monotosporella shows the most important morphological features of each species (Table S1). With the exception of the Monotosporella specimens from New Caledonian resin, all other extant species have been collected on decaying or rotten plant material. The teleomorph is only known for two such species (the Monotosporella state of Ascotaiwania sawada and Ascotaiwania mitriformis). In comparison with modern Monotosporella species, it is quite striking that the Monotosporella specimen in Indian amber has very short 

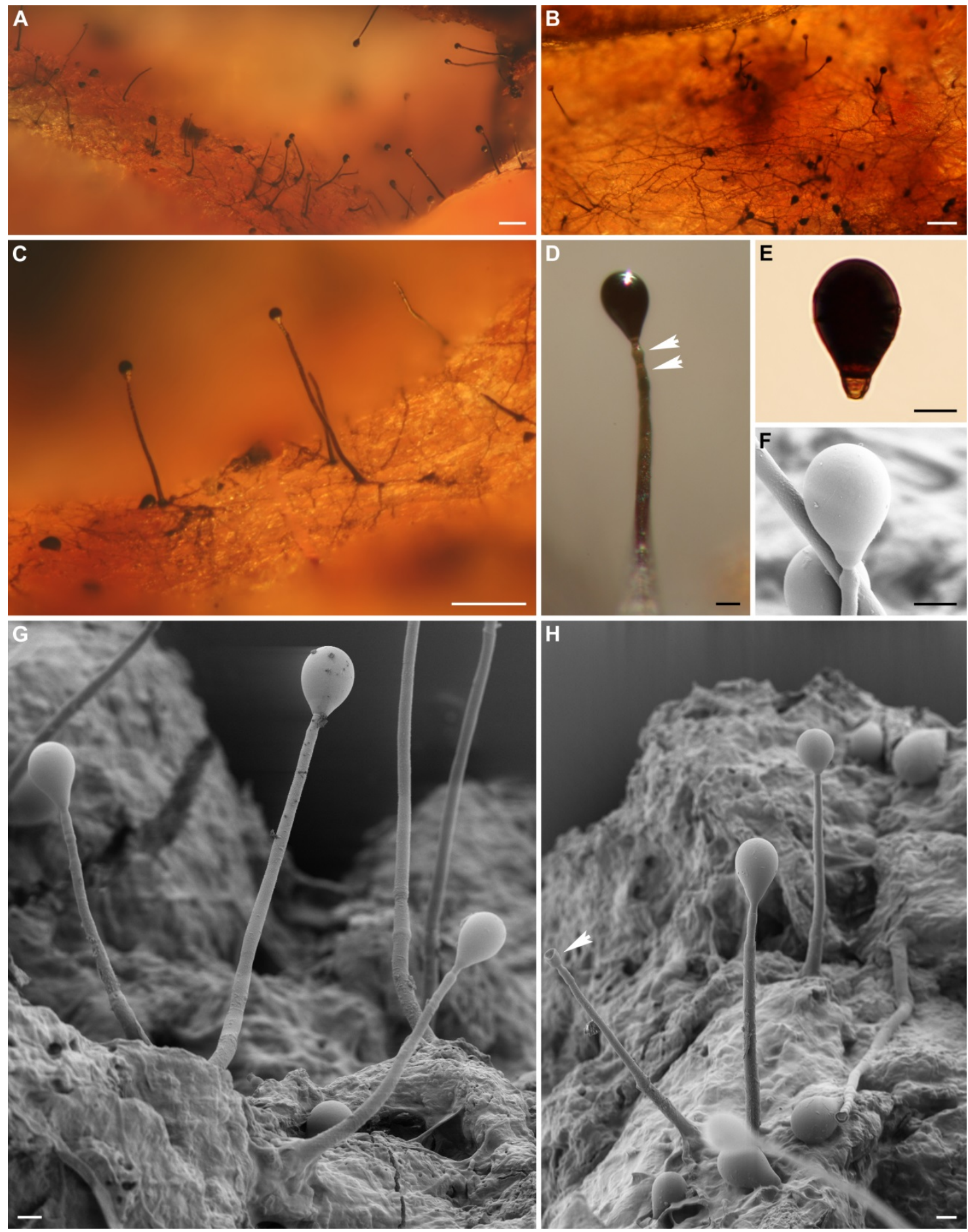

Figure 4. Light (A-E) and scanning electron (F-H) micrographs of Monotosporella setosa from New Caledonia (GZG.PB.5003). A-C Mycelium at the surface of the resin flow showing various numbers of conidiophores possessing pyriform conidia. D Conidiophore with conidium. The arrowheads indicate the slightly swollen cells in the distal part. E-F Pyriform conidia. G, H Conidiophores with conidia. The arrowhead in $(\mathrm{H})$ indicates the conidiogenous cell. Scale bars $=100 \mu \mathrm{m}$ in $(\mathrm{A}-\mathrm{C})$ and $10 \mu \mathrm{m}$ in $(\mathrm{D}-\mathrm{H})$.

conidiophores and small conidia. Concerning the length of the conidiophores, it mostly resembles the Monotosporella state of Ascotaiwania mitriformis, but the conidiophores of this species are wider at the base, and the shape of the conidia is also different. The 
Monotosporella state of Ascotaiwania sawada has very short conidiophores, but it too is distinguished from the fossil by the shape of the conidia - while the Monotosporella states of both extant Ascotaiwania species have obovate to ovate conidia, the fossil species has pyriform, relatively narrow conidia. While the size of conidiophores in $M$. clavata is quite similar to that of the fossil, it has clavate conidia with 4-6 septa. Monotosporella rhizoidea also produces short conidiophores but has turbinate to obovoidal conidia and lobe-like swellings in the conidiogenous cells. Tsui et al. (2001) reported a collection of $M$. rhizoidea without lobe-like swellings and relatively short conidiophores (50-80 $\mu \mathrm{m}$ long and 4-5 $\mu \mathrm{m}$ wide). However, the obovoid to pyriform conidia of this species are broader and larger $(32-35 \times 20-25 \mu \mathrm{m})$ than those of the fossil. Monotosporella setosa sensu stricto and the varieties M. setosa var. setosa as well as $M$. setosa var. macrospora produce relatively large conidia and very long conidiophores. The recently described species M. palmicola and M. sphaerica (Yanna and Hyde 2002) have clavate, broadly ellipsoidal to spherical conidia and long conidiophores. Dactylella microaquatica resembles the fossil Monotosporella specimen in the length of the conidiophores but differs in size and shape of the conidia. Thus, all presently known extant Monotosporella species can be distinguished from the fossil taxon.

\section{Palaeoecology of Monotosporella doerfeltii}

During the Early Eocene Climatic Optimum, tropical ecosystems spread globally up to palaeolatitudes that ranged from 55 to $65^{\circ} \mathrm{N}$ and $\mathrm{S}$ (Collinson 2003), and India was covered by a dense, multi-storeyed rain forest (Morley 2000). The primary overstory tree species in these forests belonged to the resin-producing family Dipterocarpaceae (Rust et al. 2010). The root tip, arthropod fragments, faecal pellets and plant remains in the amber specimen suggest that the resin piece most likely solidified in the leaf litter horizon of the forest floor.

The substrate of Monotosporella doerfeltii is composed of a relatively loose hyphal mat with some immersed globose structures. We therefore suppose that the substrate is of fungal origin. Regarding the identity of the substrate, we must first consider the possibility that the fossil Monotosporella was preserved growing on its teleomorph. Until now, there are only two known teleomorphs of Monotosporella, assigned to the genus Ascotaiwania (Sivichai et al. 1998; Ranghoo and Hyde 1998). Ascotaiwania was first described by Sivanesan and Chang (1992) as an amphisphaeriaceous genus of the Ascomycota with solitary to aggregated globose perithecia that are immersed in the substrate and do not have a stroma. The globose structures found in the substrate of the fossil Monotosporella might represent perithecia because of their form, their 
arrangement in groups, and the dark centres that might represent ostioles (Fig. 1D). However, important characteristics of Ascotaiwania such as the peridium, the asci and the ascospores, are not visible, and there is no direct evidence that the conidiophores and globular structures would have been produced by the same fungus. Because of the relatively loose arrangement of hyphae in the fungal substrate, it is unlikely that it would represent a mushroom stalk fragment or comparable fruiting body, since fungal mycelia of such structures tend to be dense and regularly arranged.

On the basis of overall structure, we suggest that the substrate represents a fragment of a partly decayed fruticose lichen. Fruticose lichens may have hair-like, strap-shaped or shrubby thalli. In most cases, their medulla consists of loosely interwoven hyphae forming a cottony layer with abundant internal air space (Büdel and Scheidegger 2008). The deep furrows in the fossil substrate actually expose loosely interwoven hyphae resembling the fluffy medulla of fruticose lichens. Moreover, the substrate shows pale hyphae at its surface that could be interpreted as remains of the lichen cortex (Fig. 1C). Other evidence for a lichen affinity are the globose structures that are found slightly submerged in the thallus and resemble pycnidia, as well as scale-like microscopic bodies that we interpret as soredia (Fig. 1E). Although some characteristics such as algae cells or the basal squamules are missing in the fossil, probably due to initial decay, the general shape of the lichen body resembles the extant genus Cladonia (Lecanorales). Following the genus description by Sandstede (1931), some similarities between the fossil inclusion and the genus Cladonia are obvious. The pycnidia of Cladonia are located at the top of the podetia or its branches, and sometimes they also occur at the edge of the lobes. In the structure inside the amber, the location of the assumed pycnidia is nearly the same, since they are submerged at the edge of the upper part of the presumed podetium (Fig. 1A). Sandstede (1931) describes the pycnidia of Cladonia as cylindric, ovate or spherical with an average size ranging between 60-100 $\mu \mathrm{m}$ and small black pores (ostioles). These characteristics are very similar to the morphological features of the fossil specimen, since the pycnidia are globose and possess ostiole-like openings (Fig. 1D).

Considering the palaeoecological background (Rust et al. 2010), the assumed lichen was most likely corticolous, since terrestrial cladoniform lichens are not very abundant in the litter horizon of tropical rainforests today due to their high light requirement (Sipman and Harris 1989). Nevertheless, some terricolous Cladonia do occur in the tropics, sometimes covering rock outcrops or sand fields (e.g. Ahti 2000). Since the Indian amber was probably deposited in a near-shore coastal setting (Rust et al. 2010), it is possible that the lichen derived from a coastal habitat. However, many other Cladonia species grow epiphytically on the bases of trees or on lignum, and some can also tolerate moderately shady habitats. In India today, the cladoniform lichens are most 
common and diverse in alpine and montane environments, but some species occur in the Indian tropics as well (Singh 1964).

While the substrate of the fossil Monotosporella seems to represent a degraded lichen, the origin of the prominent dark-coloured hyphae on its surface (Fig. 1F) remains unclear. The dark-coloured hyphae have an average width of $6 \mu \mathrm{m}$ and are apically tapered, whereas most surrounding hyphae reach only $2.5 \mu \mathrm{m}$ and are pale to hyaline in colour (Fig. 1B, C). It is not possible to directly link the dark hyphae to the fossil lichen podetium, or to Monotosporella doerfeltii. Ellis (1959) reported that the hyphae's width in modern Monotosporella mycelia ranges from 2 to $7 \mu \mathrm{m}$, and can vary in colour from brown to pale brown. However, no species description of extant Monotosporella species mentions tapering hyphae. Consequently, this feature can either be regarded as unique for the fossil Monotosporella species, or these tapering and broad hyphae originate from another fungus that overgrew the degrading lichen as well.

We conclude that Monotosporella doerfeltii was likely growing on a degrading Cladonia-like lichen thallus in a corticolous or terrestrial microhabitat of an early tropical angiosperm rain forest.

\section{New Caledonian Monotosporella}

A morphological comparison of the Monotosporella species found on the resin flow of Agathis ovata with extant Monotosporella species is provided in Table S1. The resinicolous species is not likely to be $M$. rhizoidea, since lobe-like swellings are missing. Although there is one specimen of M. rhizoidea without the lobe-like swellings reported from a stream in Hong Kong (Tsui et al. 2001), it also can be excluded on the basis of the height of the conidiophores. The species M. clavata, M. sphaerica, $M$. palmicola and Dactylella microaquatica are distinguished from the New Caledonian specimen as well, due to the different form, septation and size of the conidia. It also seems improbable that the newly found specimen would be identical to the Monotosporella state of Ascotaiwania sawada. Although the size of the conidia is very similar, the conidiophores of this taxon are shorter than in the New Caledonian specimens. The Monotosporella state of Ascotaiwania mitriformis also differs from the New Caledonian specimen in possessing obovate to oval conidia with an average height of 10-20 $\mu \mathrm{m}$. Rather, the Monotosporella specimen from the resin flow is morphologically assignable to $M$. setosa var. setosa. Both show significant variation in the length of the conidiophores, and they also share the tapering conidiophore morphology, similar-sized pyriform conidia and septation. However, no specimens of M. setosa var. setosa have been previously reported from resin flows. 
Table S1. Synopsis of the main morphological characters of Monotosporella species as well as the Monotosporella-like anamorphs of Ascotaiwania, and the possibly related Dactylella microaquatica [from Ellis (1959), Hughes (1958, 1978), Matsushima (1975), Ranghoo et al. (1999b), Ranghoo and Hyde (1998), Rao and de Hoog (1986),

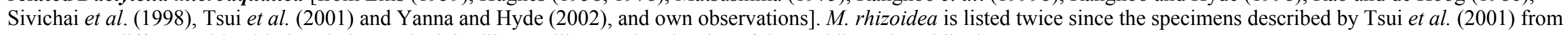
Hong Kong differ considerably in relation to the lobe-like swellings and to the size of the conidia and conidiophores.

\begin{tabular}{|c|c|c|c|c|c|c|c|c|c|c|c|c|c|}
\hline Species & $\begin{array}{l}\text { Monotosporella } \\
\text { setosa (Berk. \& } \\
\text { Curt.) Hughes } \\
1958\end{array}$ & $\begin{array}{l}\text { Monotosporella } \\
\text { setosa var. } \\
\text { setosa }\end{array}$ & $\begin{array}{l}\text { Monotosporella } \\
\text { setosa var. } \\
\text { macrospora }\end{array}$ & $\begin{array}{l}\text { Monotosporella } \\
\text { rhizoidea Rao \& } \\
\text { de Hoog } 1986\end{array}$ & $\begin{array}{l}\text { Monotosporella } \\
\text { rhizoidea Rao \& } \\
\text { de Hoog } 1986\end{array}$ & $\begin{array}{l}\text { Monotosporella } \\
\text { state of } \\
\text { Ascotaiwania } \\
\text { sawada }\end{array}$ & $\begin{array}{l}\text { Monotosporella } \\
\text { state of } \\
\text { Ascotaiwania } \\
\text { mitriformis }\end{array}$ & $\begin{array}{l}\text { Monotosporella } \\
\text { clavata Yanna } \\
\text { \& Hyde } 2002\end{array}$ & $\begin{array}{l}\text { Monotosporella } \\
\text { palmicola } \\
\text { Yanna \& Hyde } \\
2002\end{array}$ & $\begin{array}{l}\text { Monotosporella } \\
\text { sphaerica } \\
\text { Yanna \& Hyde } \\
2002\end{array}$ & $\begin{array}{l}\text { Dactylella } \\
\text { microaquatica } \\
\text { Tubaki } 1957\end{array}$ & $\begin{array}{l}\text { Monotosporella } \\
\text { from New } \\
\text { Caledonian } \\
\text { resin }\end{array}$ & $\begin{array}{l}\text { Monotosporella } \\
\text { from Indian } \\
\text { amber }\end{array}$ \\
\hline Reference & Ellis (1959) & Hughes (1978) & Hughes (1978) & $\begin{array}{l}\text { Rao and de Hoog } \\
(1986)\end{array}$ & $\begin{array}{l}\text { Tsui et al. } \\
\text { (2001) }\end{array}$ & $\begin{array}{l}\text { Sivichai et al. } \\
\text { (1998) }\end{array}$ & $\begin{array}{l}\text { Ranghoo and } \\
\text { Hyde (1998) }\end{array}$ & $\begin{array}{l}\text { Yanna and } \\
\text { Hyde (2002) }\end{array}$ & $\begin{array}{l}\text { Yanna and } \\
\text { Hyde (2002) }\end{array}$ & $\begin{array}{l}\text { Yanna and } \\
\text { Hyde (2002) }\end{array}$ & Tubaki (1957) & this study & this study \\
\hline \multicolumn{14}{|l|}{ Conidiophores } \\
\hline Length $[\mu \mathrm{m}]$ & 450 & $130-500$ & 170 & $3-40$ & $50-80$ & 8-14 & $25-75$ & $(20-52-60$ & $120-220$ & $180-200$ & $15-70$ & $90-220$ & $15-60$ \\
\hline Width $[\mu \mathrm{m}]$ & $\begin{array}{l}6-8 \\
\text { Base: 9-13 } \\
\text { Apex: 4-6 }\end{array}$ & $\begin{array}{l}\text { Base: } 12 \\
\text { Apex: } 6\end{array}$ & & Base: $4-5$ & $4-5$ & Base: $5-10$ & Base: $6-9$ & $3-4$ & $\begin{array}{l}5-8 \\
\text { Base: 6-10 } \\
\text { Apex: 3-5 }\end{array}$ & $\begin{array}{l}5-8 \\
\text { Base: } 18-20 \\
\text { Apex: } 3-6\end{array}$ & $1.5-2$ & $\begin{array}{l}\text { Base: } 9-16 \\
\text { Apex: } 3-5\end{array}$ & $\begin{array}{l}\text { Base: } 4-5 \\
\text { Apex: } 2-5\end{array}$ \\
\hline $\begin{array}{l}\text { Conidiogenous } \\
\text { cells with lobe- } \\
\text { like swellings }\end{array}$ & absent & absent & absent & present & absent & absent & absent & absent & absent & absent & absent & absent & absent \\
\hline \multicolumn{14}{|l|}{ Conidia } \\
\hline Shape & $\begin{array}{l}\text { pyriform or } \\
\text { obovoid }\end{array}$ & $\begin{array}{l}\text { pyriform to } \\
\text { obovoid }\end{array}$ & $\begin{array}{l}\text { obpyriform or } \\
\text { obovoid }\end{array}$ & $\begin{array}{l}\text { turbinate to } \\
\text { obovoidal }\end{array}$ & $\begin{array}{l}\text { obovoid to } \\
\text { pyriform }\end{array}$ & obovate to ovate & obovate to oval & clavate & clavate & $\begin{array}{l}\text { broadly } \\
\text { ellipsoidal to } \\
\text { spherical }\end{array}$ & ovoid & pyriform & pyriform \\
\hline $\begin{array}{l}\text { Size [um] } \\
\text { (height x diam.) }\end{array}$ & $20-40 \times 15-25$ & $30-50 \times 18-30$ & $38-48 \times 27-36$ & $35-40 \times 27-35$ & $32-35 \times 20-25$ & $25-35 \times 18-25$ & $10-20 \times 30-35$ & $22-30 \times 10-11$ & $48-52 \times 20-24$ & $32-36 \times 24-28$ & $10-13 \times 6.5-8$ & $31-42 \times 17-26$ & $17-28 \times 10-15$ \\
\hline Septation & $\begin{array}{l}1-3 \text { (usually 2)- } \\
\text { septate }\end{array}$ & 2-septate & 2-septate & 2(-3)-septate & 2-septate & 1-4-septate & 1-3-septate & 4-6-septate & 4-6(-7)-septate & 3-4-septate & 1-septate & 2-septate & $\begin{array}{l}1-3 \text { (usually 2)- } \\
\text { septate }\end{array}$ \\
\hline Teleomorph & unknown & unknown & unknown & unknown & unknown & $\begin{array}{l}\text { Ascotaiwania } \\
\text { sawada }\end{array}$ & $\begin{array}{l}\text { Ascotaiwania } \\
\text { mitriformis }\end{array}$ & unknown & unknown & unknown & unknown & unknown & unkown \\
\hline Substrate & $\begin{array}{l}\text { decayed wood } \\
\text { in moist places }\end{array}$ & $\begin{array}{l}\text { dead wood and } \\
\text { bark }\end{array}$ & rotten wood & $\begin{array}{l}\text { rotten bark of } \\
\text { Tectona granids }\end{array}$ & $\begin{array}{l}\text { submerged } \\
\text { wood in a } \\
\text { stream }\end{array}$ & $\begin{array}{l}\text { culture of } \\
\text { Ascotaiwania } \\
\text { sawada from } \\
\text { rotten wood in } \\
\text { freshwater } \\
\text { stream }\end{array}$ & $\begin{array}{l}\text { culture of } \\
\text { Ascotaiwania } \\
\text { mitriformis } \\
\text { from submerged } \\
\text { wood }\end{array}$ & $\begin{array}{l}\text { decaying rachis } \\
\text { of Oraniopsis } \\
\text { appendiculata }\end{array}$ & $\begin{array}{l}\text { decaying rachis } \\
\text { of Oraniopsis } \\
\text { appendiculata }\end{array}$ & $\begin{array}{l}\text { decaying rachis } \\
\text { of Oraniopsis } \\
\text { appendiculata }\end{array}$ & $\begin{array}{l}\text { submerged } \\
\text { leaves of Shiia } \\
\text { siboldi }\end{array}$ & $\begin{array}{l}\text { resin flow of } \\
\text { Agathis ovata }\end{array}$ & $\begin{array}{l}\text { lichen thallus in } \\
\text { Eocene amber }\end{array}$ \\
\hline Distribution & $\begin{array}{l}\text { South Carolina, } \\
\text { USA }\end{array}$ & New Zealand & New Zealand & India & Hong Kong & Thailand & Hong Kong & $\begin{array}{l}\text { Northern } \\
\text { Queensland, } \\
\text { Australia }\end{array}$ & $\begin{array}{l}\text { Northern } \\
\text { Queensland, } \\
\text { Australia }\end{array}$ & $\begin{array}{l}\text { Northern } \\
\text { Quensland, } \\
\text { Australia }\end{array}$ & Japan & New Caledonia & India \\
\hline
\end{tabular}




\section{Conclusions}

The morphologically defined genus Monotosporella is already known as a cosmopolitan taxon from tropical to temperate ecosystems. Lignicolous representatives have been collected from rotten wood in terrestrial and aquatic habitats, and recently epiphyllous species have been described. Our recent finds from different resinous habitats show that the genus is ecologically even more variable, with occurrences of Monotosporella in both early tropical angiosperm forests and extant tropical Araucarian forests. The apparently lichenicolous $M$. doerfeltii grew in a resinous Early Eocene dipterocarp rainforest, and is morphologically distinct from extant species, while the New Caledonian $M$. setosa is now recorded for the first time from resin flows at the bases of Agathis ovata conifers. The amber inclusion represents only the second fossil record of Sordariomycetes, the first being Gonatobotryum piceae from Eocene Baltic amber (Dörfelt and Schmidt 2007) as well as the first fossil of its particular order (either Savoryellales or Chaetosphaeriales).

\section{Acknowledgements}

We would like to thank Keith A. Seifert (Ottawa) and Steven L. Stephenson (Fayetteville) for their suggestions in the evaluation of the New Caledonian samples. We are grateful to Dorothea Hause-Reitner and Wolfgang Dröse (Göttingen) for assistance with field emission microscopy. David A. Grimaldi (New York) kindly provided access to the AMNH amber collection and permitted preparation of the amber sample. We are indebted to Kerstin Schmidt (Jena), Vincent Perrichot (Rennes) and Jérôme Munzinger (Nouméa) for assistance during the field work in New Caledonia. Field work and collection in southern New Caledonia were kindly permitted by the Direction de l'Environnement (Province sud). We are grateful to Ramesh K. Saxena (Lucknow) and to an anonymous reviewer for their constructive suggestions. H.S. thanks Ashok Sahni (Lucknow) for his encouragement and kind suggestions and would like to extend sincere thanks to the director of the Birbal Sahni Institute of Palaeobotany (Lucknow) for field and laboratory facilities. This is publication number 85 from the Courant Research Centre Geobiology, funded by the German Initiative of Excellence. 


\section{References}

Ahti T, 2000. Cladoniaceae. In: Luteyn JL, Flagler Cary M, Gradstein SR (eds), Flora Neotropica, No. 78. The New York Botanical Garden Press, Bronx, New York, pp. $3-31$.

Antoine PO, De Franceschi D, Flynn J, Nel A, Baby P, Benammi M, Calderón Y, Espurt N, Goswami A, Salas-Gismondi R, 2006. Amber from western Amazonia reveals Neotropical diversity during the middle Miocene. Proceedings of the National Academy of Sciences of the United States of America, 103: 13595-13600.

Arzanlou M, Groenewald JZ, Gams W, Braun U, Shin HD, Crous PW, 2007. Phylogenetic and morphotaxonomic revision of Ramichloridium and allied genera. Studies in Mycology 58: 57-93.

Beimforde C, Schäfer N, Dörfelt H, Nascimbene PC, Singh H, Heinrichs J, Reitner J, Rana RS, Schmidt AR, 2011. Ectomycorrhizas from a Lower Eocene angiosperm forest. New Phytologist 192: 988-996.

Beimforde C, Schmidt AR, 2011. Microbes in resinous habitats: a compilation from modern and fossil resins. Lecture Notes in Earth Sciences 131: 391-407.

Boonyuen N, Chuaseeharonnachai C, Suetrong S, Sri-Indrasutdhi V, Sivichai S, Jones EBG, Pang K-L, 2011. Savoryellales (Hypocreomycetidae, Sordariomycetes): A novel lineage of aquatic ascomycetes inferred from multiple-gene phylogenies of the genera Ascotaiwania, Ascothailandia, and Savoryella. Mycologia 103: 13511371.

Büdel B, Scheidegger C, 2008. Thallus morphology and anatomy. In: Nash TH III (ed), Lichen biology. 2nd edn. Cambridge University Press, Cambridge, pp. 40-68.

Campbell J, Shearer CA, 2004. Annulusmagnus and Ascitendus, two new genera in the Annulatascaceae. Mycologia 96: 822-833.

Caspary R, Klebs R, 1906. Die Flora des Bernsteins und anderer fossiler Harze des ostpreussischen Tertiärs. Königlich Preußische Geologische Landesanstalt, Berlin.

Collinson ME, 2003. Rise of Modern Land Plants and Vegetation. In: Briggs DEG, Crowther PR (eds), Palaeobiology II. Blackwell Science, Oxford, pp. 112-115.

Dörfelt H, Schmidt AR, 2005. A fossil Aspergillus from Baltic amber. Mycological Research 109: 956-960.

Dörfelt H, Schmidt AR, 2007. A conifer seedling with two herbicolous fungi from the Baltic amber forest. Botanical Journal of the Linnean Society 155: 449-456.

Dörfelt H, Schmidt AR, Ullmann P, Wunderlich J, 2003. The oldest fossil myxogastroid slime mould. Mycological Research 107: 123-126.

Ediger VS, 1981. Fossil fungal and algal bodies from Thrace Basin, Turkey. Palaeontographica Abteilung B 179: 87-102. 
Ellis MB, 1959. Clasterosporium and some allied Dematiaceae-Phragmosporae. II. Mycological Papers (C.M.I.) 72: 1-75.

Ellis MB, 1971. Dematiaceous hyphomycetes. Commonwealth Mycological Institute Kew, Surrey, England.

Ellis MB, 1976. More dematiaceous hyphomycetes. Commonwealth Mycological Institute Kew, Surrey, England.

Fallah PM, Crane JL, Shearer CA, 1999. Freshwater ascomycetes: two new species of Ascotaiwania from North America. Canadian Journal of Botany 77: 87-92.

Gönczöl J, 1976. Monotosporella tuberculata, a new species of aquatic Hyphomycetes from Hungary. Nova Hedwigia 17: 493-500.

Hibbett DS, Grimaldi D, Donoghue MJ, 1997. Fossil mushrooms from Miocene and Cretaceous ambers and the evolution of Homobasidiomycetes. American Journal of Botany 84: 981-991.

Hibbett DS, Binder M, Wang Z, Goldman Y, 2003. Another fossil agaric from Dominican amber. Mycologia 95: 685-687.

Hibbett DS, Binder M, Bischoff JF, Blackwell M, Cannon PF, Eriksson OE, Huhndorf S, James T, Kirk PM, Lücking R, Lumbsch HT, Lutzoni F, Matheny PB, McLaughlin DJ, Powell MJ, Redhead S, Schoch CL, Spatafora JW, Stalpers JA, Vilgalys R, Aime MC, Aptroot A, Bauer R, Begerow D, Benny GL, Castlebury LA, Crous PW, Dai YC, Gams W, Geiser DM, Griffith GW, Gueidan C, Hawksworth DL, Hestmark G, Hosaka K, Humber RA, Hyde KD, Ironside JE, Kõljalg U, Kurtzman CP, Larsson KH, Lichtwardt R, Longcore J, Miądlikowska J, Miller A, Moncalvo JM, Mozley-Standridge S, Oberwinkler F, Parmasto E, Reeb V, Rogers JD, Roux C, Ryvarden L, Sampaio JP, Schüßler A, Sugiyama J, Thorn RG, Tibell L, Untereiner WA, Walker C, Wang Z, Weir A, Weiss M, White MM, Winka K, Yao YJ, Zhang N, 2007. A higher-level phylogenetic classification of the Fungi. Mycological Research 111: 509-547.

Holubová-Jechová V, 1972. Lignicolous Hyphomycetes from Czechoslovakia 2. Bactrodesmium. Folia Geobotanica et Phytotaxonomica 7: 407-418.

Holubová-Jechová V, 1986. Lignicolous Hyphomycetes from Czechoslovakia 8. Endophragmiella and Phragmocephala. Folia Geobotanica et Phytotaxonomica 21: 173-197.

Hughes SJ, 1953. Conidiophores, Conidia, and Classification. Canadian Journal of Botany 31: 577-659.

Hughes SJ, 1958. Revisiones hyphomycetum aliquot cum appendice de nominibus rejiciendis. Canadian Journal of Botany 36: 727-836.

Hughes SJ, 1978. New Zealand Fungi 25. Miscellaneous species. New Zealand Journal of Botany 16: 311-370. 
Hughes SJ, 1979. Relocation of species of Endophragmia auct. with notes on relevant generic names. New Zealand Journal of Botany 17: 139-188.

Kirk PM, 1985. New or interesting microfungi XIV. Dematiaceous hyphomycetes from Mt Kenya. Mycotaxon 23: 305-352.

Mägdefrau K, 1957. Flechten und Moose im baltischen Bernstein. Berichte der Deutschen Botanischen Gesellschaft 71: 433-435.

Marvanová L, Descals E, 1987. New taxa and new combination of 'aquatic hyphomycetes'. Transactions of the British Mycological Society 89: 499-507.

Matsushima T, 1975. Icones Microfungorum A Matsushima Lectorum. Published by the author. Kobe, Japan.

McNeill J, Barrie FR, Burdet HM, Demoulin V, Hawksworth DL, Marhold K, Nicolson DH, Prado J, Silva PC, Skog JE, Wiersema JH, Turland, NJ, 2006. International Code of Botanical Nomenclature (Vienna Code). Regnum Vegetabile 146: 1-568.

Morley RJ, 2000. Origin and Evolution of Tropical Rain Forests. Wiley, West Sussex, England, pp. 162-166.

Nascimbene PC, Silverstein H, 2001. The preparation of fragile Cretaceous ambers for conservation and study of organismal inclusions. In: Grimaldi D (ed.), Studies on Fossils in Amber, with Particular Reference to the Cretaceous of New Jersey. Backhuys Publishers, Leiden, pp. 93-102.

Palm ME, Stewart EL, 1982. Two new combinations in Bactrodesmium. Mycotaxon 15: 319-325.

Poinar GO Jr, Buckley R, 2007. Evidence of mycoparasitism and hypermycoparasitism in Early Cretaceous amber. Mycological Research 111: 503-506.

Poinar GO Jr., Singer R, 1990. Upper Eocene Gilled Mushroom from the Dominican Republic. Science 248: 1099-1101.

Raja HA, Stchigel AM, Miller AN, Crane JL, Shearer CA, 2007. Hyphomycetes from the Great Smoky Mountains National Park, including three new species. Fungal Diversity 26: 271-286.

Ranghoo VM, Hyde KD, 1998. Ascomycetes from freshwater habitats: Ascolacicola aquatica gen. et sp. nov. and a new species of Ascotaiwania from wood submerged in a reservoir in Hong Kong. Mycologia 90: 1055-1062.

Ranghoo VM, Hyde KD, Liew ECY, Spatafora JW, 1999a. Family placement of Ascotaiwania and Ascolacicola based on DNA sequences from the large subunit rRNA gene. Fungal Diversity 2: 159-167.

Ranghoo VM, Goh TK, Hyde KD, 1999b. New observations on Monotosporella rhizoidea. Mycoscience 40: 377-382.

Rao V, de Hoog GS, 1986. New or critical Hyphomycetes from India. Studies in Mycology 28: 1-84. 
Réblová M, Seifert KA, 2004. Conioscyphascus, a new ascomycetous genus for holomorphs with Conioscypha anamorphs. Studies in Mycology 50: 95-108.

Réblová M, Seifert KA, 2011. Discovery of the teleomorph of the hyphomycete, Sterigmatobotrys macrocarpa, and epitypification of the genus to holomorphic status. Studies in Mycology 68: 193-202.

Rikkinen J, 1999. Two new species of resinicolous Chaenothecopsis (Mycocaliciaceae) from western North America. The Bryologist 102: 366-369.

Rikkinen J, 2003. Chaenothecopsis nigripunctata, a remarkable new species of resinicolous Mycocaliciaceae from western North America. Mycologia 95: 98-103.

Rikkinen J, Poinar GO Jr, 2000. A new species of resinicolous Chaenothecopsis (Mycocaliciaceae, Ascomycota) from 20 million year old Bitterfeld amber, with remarks on the biology of resinicolous fungi. Mycological Research 104: 7-15.

Rikkinen J, Poinar GO Jr, 2008. A new species of Phyllopsora (Lecanorales, lichenforming Ascomycota) from Dominican amber, with remarks on the fossil history of lichens. Journal of Experimental Botany 59: 1007-1011.

Rikkinen J, Dörfelt H, Schmidt AR, Wunderlich J, 2003. Sooty moulds from European Tertiary amber, with notes on the systematic position of Rosaria ('Cyanobacteria'). Mycological Research 107: 251-256.

Rossi W, Kotrba M, Tribell D, 2005. A new species of Stigmatomyces from Baltic amber, the first fossil record of Laboulbeniomycetes. Mycological Research 109: 271-274.

Rust J, Singh H, Rana RS, McCann T, Singh L, Anderson K, Sarkar N, Nascimbene PC, Stebner F, Thomas JC, Solórzano Kraemer M, Williams CJ, Engel MS, Sahni A, Grimaldi D, 2010. Biogeographic and evolutionary implications of a diverse paleobiota in amber from the early Eocene of India. Proceedings of the National Academy of Sciences of the United States of America 107: 18360-18365.

Sandstede H, 1931. Die Gattung Cladonia. In: Zahlbruckner A (ed.), Dr. L Rabenhorst's Kryptogamen-Flora Vol. 9. Part IV, Die Flechten (Lichenes). Akademische Verlagsgesellschaft, Leipzig, pp. 10-17.

Schmidt AR, Ragazzi E, Coppellotti O, Roghi G, 2006. A microworld in Triassic amber. Nature 444: 835.

Schmidt AR, Dörfelt H, Perrichot V, 2007. Carnivorous fungi from Cretaceous amber. Science 318: 1743.

Schmidt AR, Perrichot V, Svojtka M, Anderson KB, Belete KH, Bussert R, Dörfelt H, Jancke S, Mohr B, Mohrmann E, Nascimbene PC, Nel A, Nel P, Ragazzi E, Roghi G, Saupe EE, Schmidt K, Schneider H, Selden PA, Vávra N, 2010a. Cretaceous African life captured in amber. Proceedings of the National Academy of Sciences of the United States of America 107: 7329-7334. 
Schmidt AR, Dörfelt H, Struwe S, Perrichot V, 2010b. Evidence for fungivory in Cretaceous amber forests from Gondwana and Laurasia. In: Wappler T., Gee CT (eds), Plant-animal interactions in deep time: predation, protection, pollination. Palaeontographica, Abteilung B 283: 157-173.

Schoch CL, Crous PW, Groenewald JZ, Boehm EWA, Burgess TI, de Gruyter J, de Hoog GS, Dixon LJ, Grube M, Gueidan C, Harada Y, Hatakeyama S, Hirayama K, Hosoya T, Huhndorf SM, Hyde KD, Jones EBG, Kohlmeyer J, Kruyes A, Li YM, Lücking R, Lumbsch HT, Marvanová L, Mbatchou JS, McVay AH, Miller AN, Mugambi GK, Muggia L, Nelsen MP, Neson P, Owensby CA, Phillips AJL, Phongpaichit S, Pointing SB, Pujade-Renaud V, Raja HA, Rivas Plata E, Robbertse B, Ruibal C, Sakayaroj J, Sano T, Selbmann L, Shearer CA, Shirouzu T, Slippers B, Suetrong S, Tanaka K, Volkmann-Kohlmeyer B, Wingfield MJ, Wood AR, Woudenberg JHC, Yonezawa H, Zhang Y, Spatafora JW, 2009. A class-wide phylogenetic assessment of Dothideomycetes. Studies in Mycology 64: 1-15.

Singh A, 1964. Lichens of India. In: Bulletin of the National Botanic Gardens. No. 93, National Botanic Gardens, Lucknow, p. 22.

Sipman HJM, Harris RC, 1989. Lichens. In: Lieth H, Werger MJA (eds), Ecosystems of the World. Vol. 14. Part B., Tropical Rain Forest Ecosystems. Elsevier, Amsterdam, Oxford, New York, Tokyo, pp. 303-309.

Sivanesan A, Chang HS, 1992. Ascotaiwania, a new amphisphaeriaceous ascomycete genus on wood from Taiwan. Mycological Research 96: 481-484.

Sivichai S, Hywel-Jones N, Jones EBG, 1998. Lignicolous freshwater Ascomycota from Thailand: 1. Ascotaiwania sawada and its anamorph state Monotosporella. Mycoscience 39: 307-311.

Thomas GM, Poinar GO Jr., 1988. A fossil Aspergillus from Eocene Dominican amber. Journal of Paleontology 62: 141-143.

Tibell L, Titov A, 1995. Species of Chaenothecopsis and Mycocalicium (Caliciales) on exudate. The Bryologist 98: 550-560.

Tsui CKM, Goh TK, Hyde KD, Hodgkiss IJ, 2001. New species or records of Cacumisporium, Helicosporium, Monotosporella and Bahusutrabeeja on submerged wood in Hong Kong streams. Mycologia 93: 389-397.

Tubaki K, 1957. Studies on Japanese Hyphomycetes, III. Aquatic group. Bulletin of the National Science Museum Tokyo 3: 249-268.

Tuovila H, Cobbinah JR, Rikkinen J, 2011a. Chaenothecopsis khayensis, a new resinicolous calicioid fungus on African mahogany. Mycologia 103: 610-615.

Tuovila H, Larsson P, Rikkinen J, 2011b. Three resinicolous North American species of Mycocaliciales in Europe with a re-evaluation of Chaenothecopsis oregana Rikkinen. Karstenia 51: 37-49. 
Yanna, Hyde KD, 2002. New saprobic fungi on fronds of palms from northern Queensland, Australia. Australian Systematic Botany 15: 755-764.

Zhang Y, Schoch CL, Fournier J, Crous PW, Gruyter J De, Woudenberg JHC, Hirayama K, Tanaka K, Pointing SB, Hyde KD, 2009. Multi-locus phylogeny of the Pleosporales: a taxonomic, ecological and evolutionary re-evaluation. Studies in Mycology 64: 85-102. 


\section{Appendix 4}

Schmidt AR, Beimforde C, Seyfullah LJ, Wege SE, Dörfelt H, Girard V, Grabenhorst H, Gube M, Heinrichs J, Nel A, Nel P, Perrichot V, Reitner J, Rikkinen J (in review). Amber fossils of sooty moulds. Review of Palaeobotany and Palynology.

Impact factor of Review of Palaeobotany and Palynology 2011: 1,914 according to Journal Citation Reports 


\section{Amber fossils of sooty moulds}

Alexander R. Schmidt ${ }^{\mathrm{a},}{ }^{,}$, Christina Beimforde ${ }^{\mathrm{a}}$, Leyla J. Seyfullah ${ }^{\mathrm{a}}$, Sarah-Elena Wege ${ }^{\mathrm{a}}$, Heinrich Dörfelt ${ }^{\mathrm{b}}$, Vincent Girard ${ }^{\mathrm{c}, \mathrm{d}}$, Heinrich Grabenhorst ${ }^{\mathrm{e}}$, Matthias Gube ${ }^{\mathrm{b}}$, Jochen Heinrichs ${ }^{\mathrm{f}, \mathrm{g}}$, André $\mathrm{Nel}^{\mathrm{h}}$, Patricia Nel ${ }^{\mathrm{h}, \mathrm{i}}$, Vincent Perrichot ${ }^{\mathrm{j}}$, Joachim Reitner ${ }^{\mathrm{a}}$, Jouko Rikkinen $^{\mathrm{k}}$

${ }^{a}$ Courant Research Centre Geobiology, Georg-August-Universität Göttingen, Goldschmidtstr. 3, 37077 Göttingen, Germany, ${ }^{b}$ Mikrobielle Phytopathologie, Friedrich-Schiller-Universität, Neugasse 25, 07743 Jena, Germany, ${ }^{c}$ Centre de Bio-Archéologie et d'Ecologie (UMR 5059 CNRS/Université Montpellier 2/EPHE/INRAP), Institut de Botanique, 163 Rue Auguste Broussonet, 34090 Montpellier, France, ${ }^{\mathrm{d}}$ Université Montpellier 2, Place Eugène Bataillon, 34095 Montpellier, France; ${ }^{\mathrm{e}}$ Nachtigallenweg 9 , 29342 Wienhausen, Germany, ${ }^{\mathrm{f}}$ Albrecht-von-Haller-Institut für Pflanzenwissenschaften, Abteilung Systematische Botanik, Georg August-Universität Göttingen, Untere Karspüle 2, 37073 Göttingen, Germany, ${ }^{g}$ Systematic Botany and Mycology, Faculty of Biology, University of Munich (LMU), Menzinger Str. 67, 80638 Munich, Germany, ${ }^{\mathrm{h}}$ Muséum National d'Histoire Naturelle, CNRS UMR 7205, Entomologie, 75005 Paris, France, ${ }^{i}$ AgroParisTech, 16 rue C. Bernard, 75231 Paris Cedex 05

${ }^{\mathrm{j}}$ Observatoire des Sciences de l'Univers de Rennes, CNRS UMR 6118 Géosciences, Université Rennes 1, 35042 Rennes cedex, France, ${ }^{\mathrm{k}}$ Department of Biosciences, P.O. Box 65, FIN-00014 University of Helsinki, Finland

Corresponding author: Alexander R. Schmidt (alexander.schmidt@geo.uni-goettingen.de) 


\begin{abstract}
Sooty moulds are saprophytic ascomycetes with brown hyphae, often forming extensive subicula on living plant surfaces. These fungi grow on plant exudates and honeydew secreted by sap sucking insects and are ubiquitous in many humid terrestrial ecosystems. Investigation of Mesozoic and Cenozoic ambers from different parts of the world revealed sooty moulds from eight northern hemisphere amber deposits. This traces the fossil record of these fungi for approximately 100 million years, from the Early Miocene (16 million years) back to the Early Cretaceous (Albian, about 113 to 100 million years). Fragments of superficial subicula composed of smooth brown moniliform hyphae with tapering distal ends identical to those produced by extant species in the family Metacapnodiaceae (Capnodiales) are recorded since the Albian. The fossil fungi originate from tropical to temperate coastal forests where they grew on leaves and bark of different conifers and angiosperm trees. This indicates that capnodialean sooty moulds have occupied their specialized niche since at least from when early angiosperms appeared in the fossil record.
\end{abstract}

Key words: Capnodiales, fossil fungi, Metacapnodiaceae, Metacapnodium 


\section{Introduction}

The term sooty moulds is used in a vernacular sense for an ecological group of epiphytic ascomycetes with dark-colored hyphae that often produce conspicuous black growth on the leaves and other surfaces of living plants (Hughes 1976; Seifert et al., 2011). Sooty moulds are not parasitic but get their nutrition from insect excretions, especially the honey dew produced by sap sucking aphids and scale insects, and from plant leachates and exudates, such as the nectar secreted by extrafloral nectaries. They tend to form diverse assemblages, often also including filamentous taxa that are parasites of other fungi. These fungal communities may encompass capnodialean (Capnodiales, Dothideomycetes) species within the families Antennulariellaceae, Capnodiaceae, and Metacapnodiaceae, but also ecologically and morphologically similar fungi from other distantly related groups. For example, some species in the Chaetothyriaceae (Eurotiomycetes) share the same niche and convergent morphology; they also appear as melanized, usually anamorphic epiphytes (e.g. Chomnunti et al., 2012a, 2012b). The main differences are in the characteristics of the ascomata, which are not necessarily produced in most specimens. As many sooty mould species are highly pleomorphic and do not readily grow in culture, their identification is quite challenging (e.g. Hughes 1976, 2003, 2007; Reynolds 1986, 1998; Sugiyama and Amano 1987; Faull et al., 2002; Crous et al., 2009; Cheewangkoon et al., 2009; Chomnunti et al., 2011).

The Capnodiales, centering on Capnodiaceae, currently contain eight families (Kirk et al., 2008; Lumbsch and Huhndorf 2010). Capnodialean sooty moulds produce superficial ascomata with fasciculate asci, and have hyaline to dark, septate ascospores. Their anamorphs are dematiaceous, and may include both mycelial (phragmo- to dictyoconidia), as well as spermatial and pycnidial synanamorphs (Hughes 1976; Crous et al., 2009; Chomnunti et al., 2011). Some species within the family Metacapnodiaceae produce extensive spongy mycelia of darkly pigmented, densely interwoven and often anastamosing, monilioid, distally tapering hyphae, which are strongly constricted at the septa. This habit is characteristic enough to have given rise to the descriptive term "metacapnodiaceous hyphae" (Hughes 1976). Metacapnodium species are not presently available in culture collections and no sequences of species within the Metacapnodiaceae have yet been deposited in GenBank. Thus, the exact placement of the family among other capnolialean sooty moulds still waits to be confirmed by molecular methods.

The overall prospects for finding fossils of sooty moulds in amber, which is fossilized exudate of ancient gymnosperm and angiosperm trees, are good. The brittle and often rather loose epiphytic colonies growing on trees, especially those secreting 
exudates, almost predestine them for preservation in resin. Finding an extant species of sooty mould entrapped in fresh resin of Pinus elliottii Engelm. in a Florida swamp forest (see Schmidt \& Dilcher 2007) demonstrates that also in modern forests sooty moulds are entrapped in plant exudates (Plate 1). Indeed, metacapnodiaceous sooty moulds have already been reported from several pieces of Eocene Baltic and Oligocene Bitterfeld amber (Rikkinen et al., 2003), and recently small hyphal fragments and conidia were identified on the cuticle of a thrips in Early Eocene amber from the Paris Basin (Nel et al., in press). Other amber inclusions of possible sooty moulds have been mentioned from the Albian of France (Girard et al., 2009a) and Myanmar (Hentschel et al., 2009) as well as from the Cenomanian of Ethiopia (Schmidt et al., 2010a).

Here, we describe and discuss a collection of fossils of sooty moulds recovered from eight Albian to Miocene amber deposits. These inclusions allow tracing back the fossil record of capnodialean fungi to the Early Cretaceous.

\section{Material and methods}

The amber pieces investigated originate from eight northern hemispheric amber deposits. Plate 1 provides data about provenance, age and deposition of the pieces investigated.

The amber pieces were ground and polished manually using a series of wet silicon carbide papers [grit from FEPA P $600-4000(25.8 \mu \mathrm{m}$ to $5 \mu \mathrm{m}$ particle size), firm Struers]. A fraction of a millimeter of amber surface was gradually removed from each amber piece, while frequently checking the preparation under a stereoscope to ensure that the inclusions were not damaged. The flattened surface of the amber was brought to about $100 \mu \mathrm{m}$ of the inclusions, if no valuable syninclusions were affected (see Schmidt et al., 2012, for protocols).

Prepared specimens were placed on a glass microscope slide with a drop of water applied to the upper surface of the amber, covered with a $0.06-0.08 \mathrm{~mm}$ thick glass coverslip (Menzel Inc., Braunschweig). This reduces light scattering from fine surface scratches and improves optical resolution. Amber from the Austrian Traunsee locality is very brittle and thus fragments of a size of less than $1 \mathrm{~mm}$ were placed in water on concave glass microscope slides (Menzel Inc., Braunschweig) and covered by a glass coverslip to reduce light scattering.

The preparations were examined under a Carl Zeiss AxioScope A1 compound microscope equipped with a Canon 450D digital camera. Sometimes incident and transmitted light were used simultaneously. The images of Plates 1, 2 (2-7), 3 (1-5, 7, 8) and 4-6 were obtained from several focal planes using the software package HeliconFocus 5.0 to enable a better illustration of the three-dimensional inclusions. 

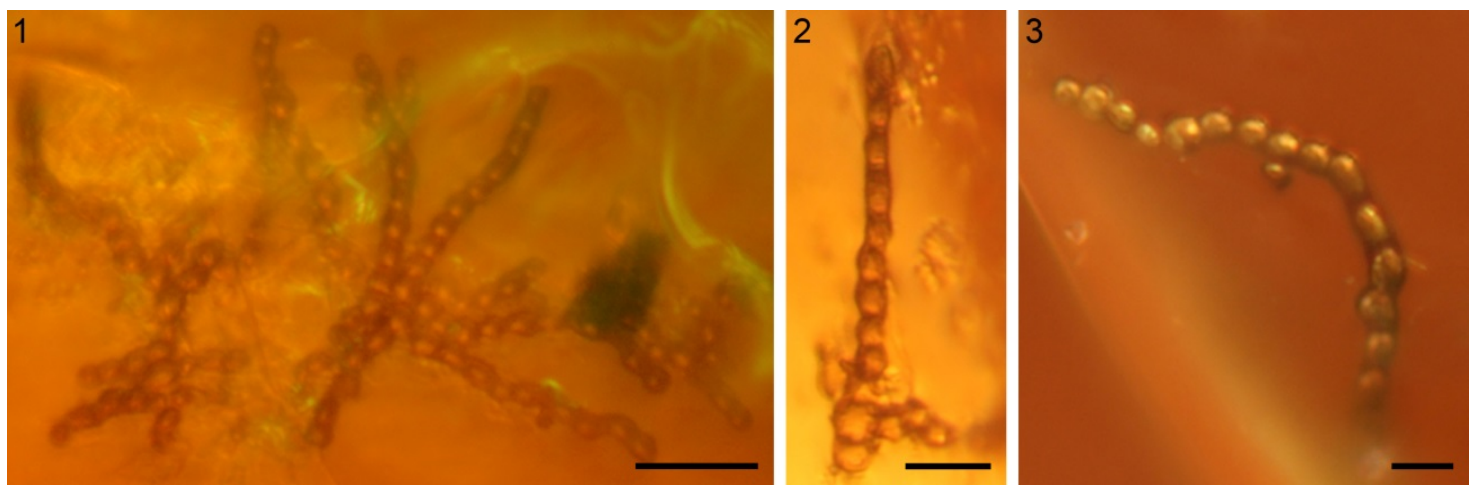

Plate 1. Fragments of a subiculum of an extant sooty mould in resin of Pinus elliottii in a swamp forest east of Gainesville, Florida. Geoscientific Collections of the Georg August University Göttingen, Germany; GZG.PB.5003. Scale bars: $20 \mu \mathrm{m}$.

\section{Results}

\section{Metacapnodiaceous sooty moulds as amber inclusions}

Phylum Ascomycota Cavalier-Smith 1998

Class Dothideomycetes O. E. Erikss. et Winka 1997

Àlava amber. Museo de Ciencias Naturales de Àlava, no. MCNA 9495 (Plate 2, 1). Several dark brown moniliform hyphae up to $280 \mu \mathrm{m}$ in length are attached to spider silk. The cells are smooth, globose to subglobose and about $12 \mu \mathrm{m}$ in diameter with apical cells being slightly smaller. Syninclusions are fragments of a spider web and the paratype of the stigmaphronid wasp Hippocoon basajauni Ortega-Blanco, Delclòs et Engel (Ortega-Blanco et al., 2011).

Charentese amber. Amber collection of Géosciences Rennes at the University Rennes 1, no. IGR.ARC-115.3b (Plate 2, 2); and Muséum National d'Histoire Naturelle, Département Histoire de la Terre, amber piece no. MNHN.F.A30167-30168 (Plate 2, 3-6). One fragment of branched dark brown superficial (aerial) moniliform hyphae (IGR.ARC-115.3b), and a hyphal network of the same dark color (MNHN.F.A3016730168) are preserved. The cells of the aerial hyphae are smooth, thick-walled, globose (or rarely subglobose) and 7-10 $\mu \mathrm{m}$ in diameter with walls up to $1.5 \mu \mathrm{m}$ thick (Plate 2, 2). One dividing stage is preserved with the apical cell being $6 \mu \mathrm{m}$ in diameter. The cells of the hyphal network are largely globose, subglobose and obovate, or rarely elongate (Plate 2, 3-6). Globose cells are about $6 \mu \mathrm{m}$ in diameter, subglobose cells are 6-9 x 4-6 $\mu \mathrm{m}$, obovate cells are 4.5-6 x 7.5-11 $\mu \mathrm{m}$ in size; elongate cells are 3-5 wide and 6-19 $\mu \mathrm{m}$ long. Bark remains and tracheids are preserved attached to the subiculum. Further syninclusions are two sand flies (Diptera: Psychodidae) of the species 
Eophlebotomus carentonensis Azar, Perrichot, Néraudeau et A. Nel (Azar et al., 2003), a diatom of the genus Paralia (Girard et al., 2009b), and the testate amoeba Centropyxis perforata A. R. Schmidt, Girard et Schönborn (Schmidt et al., 2010b). These two amber preparations represent fragments of one of the most species rich amber pieces ever found, containing over 80 arthropods and a plethora of microorganisms (see Perrichot $\&$ Girard 2009).
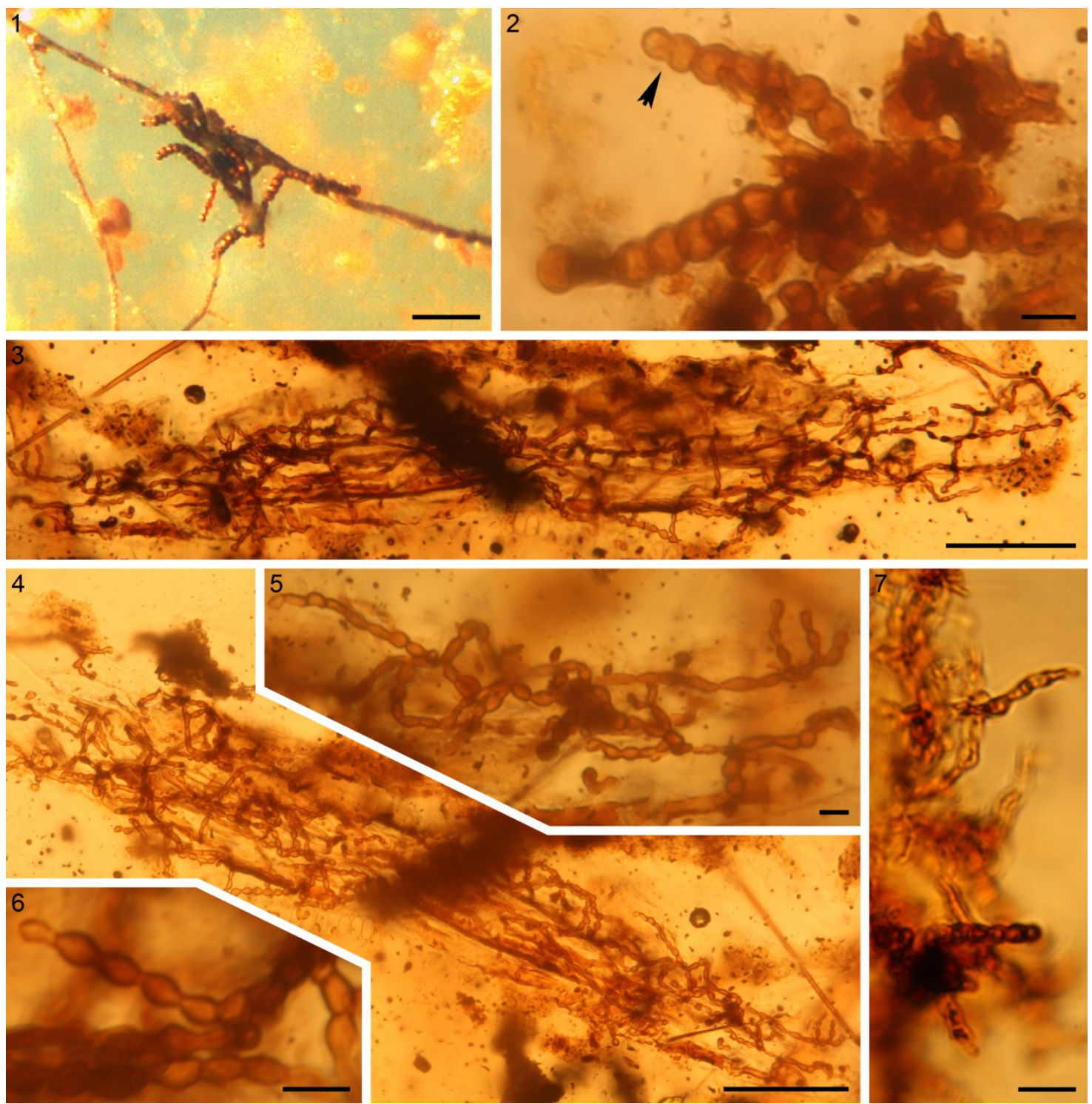

Plate 2. Sooty moulds in Early Cretaceous ambers from Spain and France, and from the Late Cretaceous of Austria. 1. Moniliform hyphae of sooty mould trapped on spider silk in Albian amber from Àlava (Peñacerrada, Spain). MCNA 9495. 2 Metacapnodiaceous sooty mould in amber from Archingeay (France) IGR.ARC-115.3b. 3-6. Mycelium originally preserved in the same amber piece and possibly representing a basal extension of the aerial hyphae shown in (b), (b) MNHN.F.A30167-30168, (d) view from the opposite side. 7. Sooty moulds in Traunsee amber from Austria GZG.BST.27295. Scale bars: $100 \mu \mathrm{m}(\mathrm{a}, \mathrm{c}$ and $\mathrm{d})$ and $10 \mu \mathrm{m}(\mathrm{b}, \mathrm{e}-\mathrm{g})$. 
San Just amber. Geoscientific Collections of the Georg August University Göttingen, no. GZG.BST.27287 (Plate 3). Several fragmentary brown hyphae are exquisitely preserved (Plate 3, 1). The hyphae are sometimes branched (wide angled), anastomosing, and distally tapering (Plate 3, 2-3). The cells of superficial (aerial) hyphae are smooth, globose to subglobose, thick-walled and 4.5-13.5 x 9-15 $\mu \mathrm{m}$ in size. Other hyphae (likely formerly substrate-attached) possess smaller barrel-shaped cells, reaching only 6-7.5 x 6-9 $\mu \mathrm{m}$. One apical dividing stage is preserved (Plate 3, 3). Plate 3 (6-9) show the conidial state of the fungus. The conidia are mostly two-celled (rarely one-celled), $10.5-12 \times 13.5-15 \mu \mathrm{m}$ (rarely $17 \mu \mathrm{m}$ ) in size, either attached to the hypha in clusters or occurring free in the amber. The conidiogenous cells are hardly visible due to the location of the inclusion with respect to the polished amber surface. However, the detail shown in Plate 3 (7) seems to represent the detachment point of one conidium. Syninclusions are numerous prokaryotic filaments resembling Leptotrichites resinatus Schmidt (Schmidt \& Schäfer 2005).

Traunsee amber. Geoscientific Collections of the Georg August University Göttingen, no. GZG.BST.27295 (Plate 2, 7). A dark brown hyphal network and numerous detached short dark brown hyphae are preserved in a tiny amber piece. The cells are smooth, globose and only $2.3-4 \times 3 \mu \mathrm{m}$ in size. These fungi represent the only inclusions described from this small amber deposit, so far.

Oise amber. Muséum National d'Histoire Naturelle de Paris, département Histoire de la Terre, no. MNHN-F.A38531 (Plate 4). Numerous dark hyphal fragments are attached to the cuticle of the bark-dwelling thrips species Uzelothrips eocenicus P. Nel et A. Nel (Thysanoptera, Uzelothripidae; see Nel at al. in press). The cells are mostly globose to subglobose and 3 to $6 \mu \mathrm{m}$ diameter. Few elongate cells reach 8 to $10 \mu \mathrm{m}$ length and 4 $\mu \mathrm{m}$ diameter. Four-celled conidia and hyphae with tapering tips with dividing stages are preserved.

Baltic amber. Metacapnodium succinum (Dörfelt, A. R. Schmidt et Wunderl.) Rikkinen, Dörfelt, A. R. Schmidt et Wunderl. (Rikkinen et al., 2003). Senckenberg collection, no. SMF Be 526a (holotype, formerly collection Jörg Wunderlich, no. F70/BB/PL/CYA/CJW), Geoscientific Collections of the Georg August University Göttingen, no. GZG.BST.27288-27290 (formerly collection Volker Arnold, no. 1368, 1371, 1906; Plates 5, 1-4, 6), collection Volker Arnold (sine numero), and collection Michael Oschin, no. 5/01. Fragments of superficial, spongy subicula consiting of brown to dark moniliform hyphae are preserved in several pieces of Baltic amber. The hyphae are much branched, with tapering distal ends. They possess wide-angled branchings, with most branches arising at more or less right angles and curving upwards. 
Anastomosing hyphae occur occasionally. The cells are widely cylindrical to subglobose, deeply constricted at the septa, usually $9-13 \times 8-12 \mu \mathrm{m}$ in diameter with smooth and relatively thick walls; oldest cells are up to 15 (rarely 20) $\mu \mathrm{m}$ wide. A Capnosporium conidial state is preserved in specimen GZG.BST.27288 (Arnold 1368). The detached hyphal segments are straight, 2-6-septate, 15-53 $\mu \mathrm{m}$ long, 5-9 $\mu \mathrm{m}$ wide, cylindrical to obovoid, with smaller cells at both ends, similar to poroconidia of extant Metacapnodium species. The conidia were probably produced at the apexes of erect hyphal branches.
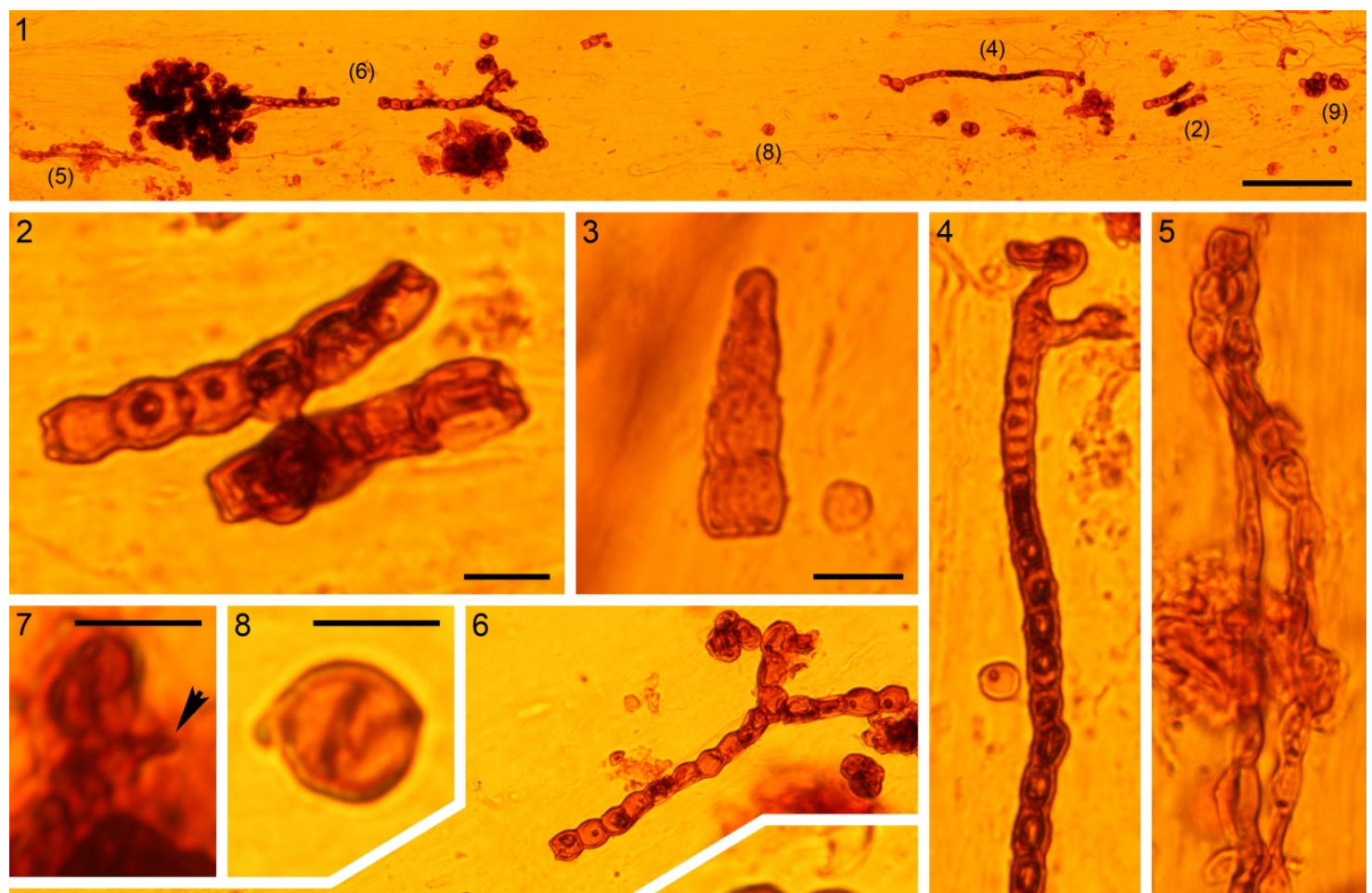

\section{6}
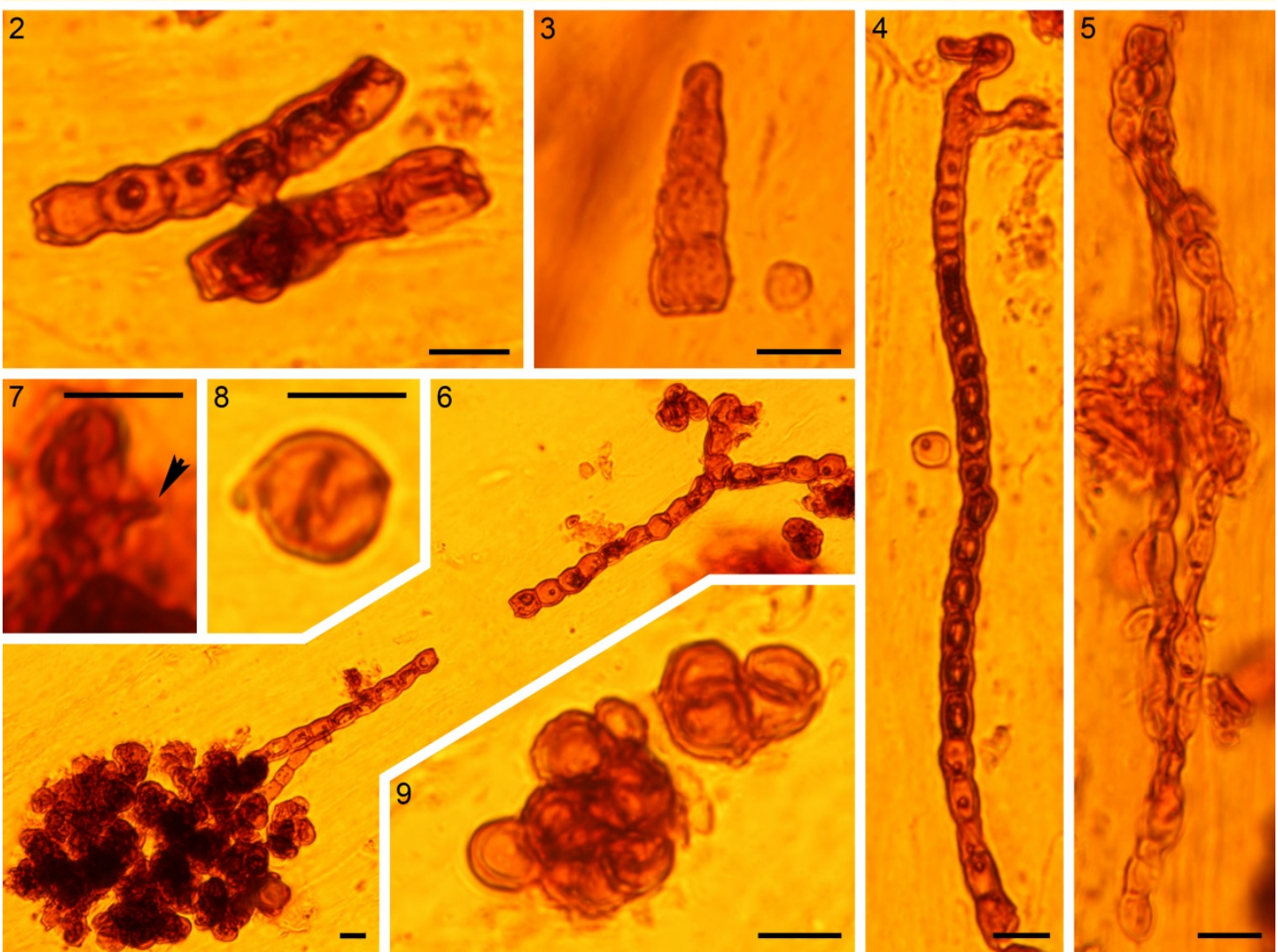

Plate 3. Metacapnodiaceous sooty mould in Albian amber from San Just (Spain) GZG.BST.27287.

1. Overview of subiculum fragments. The letters in brackets indicate the enlarged views of the other panels. 2. Anastomosing hyphae. 3. Tapering hyphal tip, 4. Aerial hypha. 5. Hyphae of the basal subiculum, 6. Conidial state. 7. Conidiogenous cells with detachment point (arrowhead). 8. Two-celled conidium. 9. Cluster of septate conidia. Scale bar $100 \mu \mathrm{m}$ (a) and $10 \mu \mathrm{m}$ (b-i).

Bitterfeld amber. Metacapnodium succinum (Dörfelt, A. R. Schmidt et Wunderl.) Rikkinen, Dörfelt, A. R. Schmidt et Wunderl. (Rikkinen et al., 2003). Geoscientific Collections of the Georg August University Göttingen, no. GZG.BST.27291 and 27292 (formerly collection Volker Arnold, no. 1900, 1908), (Plate 5, 5), Geoscientific 
Collections of the Georg August University Göttingen, no. GZG.BST.27293 and 27294 (formerly collection Heinrich Grabenhorst, no. Li-3 and 122. Piece number 1908 of the Arnold collection contains networks of hyphae of Metacapnodium that grew on bark and on a corticolous Cavernularia-like lichen. The globose to subglobose cells are 10$13 \times 7-10 \mu \mathrm{m}$ in diameter. One amber piece (GZG.BST.27291) contains a Capnophialophora conidial state. The Capnophialophora conidiogenous cells develop singly or in groups of 2-4 on subterminal sections of hyphal branches and are 8-10 $\mu \mathrm{m}$ in height and 6-8 $\mu \mathrm{m}$ wide. The phialides are pale brown, more or less spherical or obpyriform with a flattened base, the distal end possesses a single subhyaline collarette. Phialoconidia are not visible.

Dominican amber. Museum für Naturkunde zu Berlin, no. MB.Pb.2009-348 (Plate 6). Moniliform distally slightly tapering hyphae with right-angled branching are preserved on the surface of a gametophyte of the leafy liverwort Frullania subgen. Diastaloba (Heinrichs \& Schmidt 2010). The cells are globose to subglobose, thick-walled, verrucose to granulate, $3.9-8.3 \mu \mathrm{m}$ long and 3.9-7.8 $\mu \mathrm{m}$ wide. The size of the warts ranges between 0.55 and $1.1 \mu \mathrm{m}$.
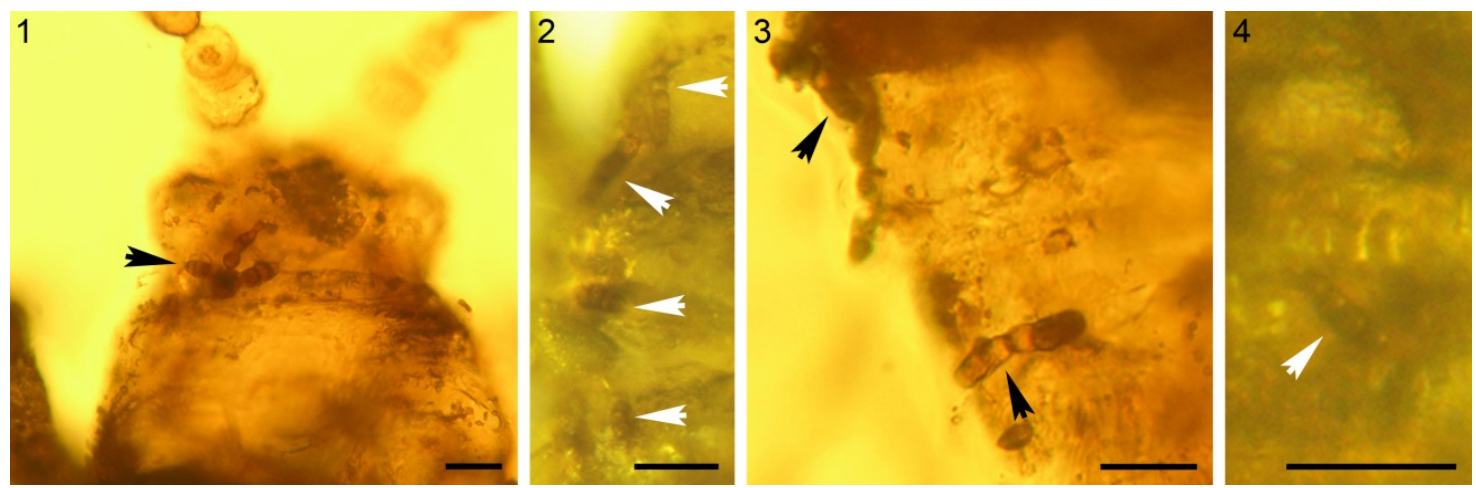

Plate 4. Sooty mould fragments attached to cuticle of the thrips species Uzelothrips eocenicus in Oise amber. 1-4. Septate condia and fragments of moniliform hyphae. Scale bars: $20 \mu \mathrm{m}$.

\section{Discussion}

\section{Two historic references to amber fossils of sooty moulds}

The first description of a fossil fungus that can convincingly be assigned to the family Metacapnodiaceae was published over 150 years ago. In 1858, Anton Menge, a Professor of Botany, Zoology and Geology in Danzig (Gdanzk), described a 'branched articulated thallus' that was found attached to the tip of a twig resembling Thuja occidentalis L. (Cupressaceae) in Baltic amber. He described the fossil as follows: 
'Thallus fruticulosus, ramosus, articulates, articulis compresso-globosis, ramis apice conicis, furcates, divergentibus. - Planta minima, crustacea, in forma caespitis apicem surculi Thuiae occidentalis obtegens, coloris brunei' (Menge 1858).
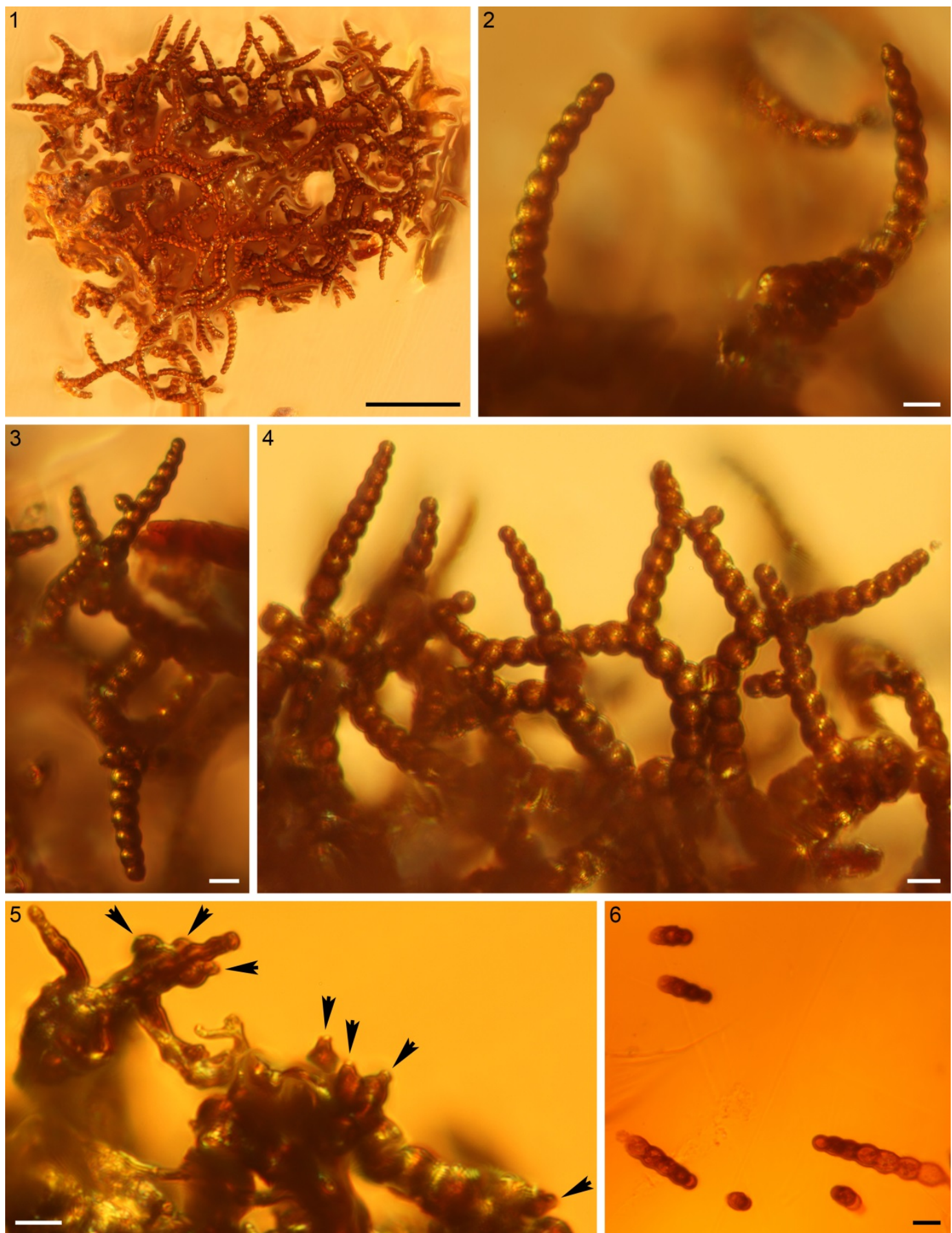

Plate 5. Metacapnodium succinum from Baltic and Bitterfeld ambers. 1. Subiculum in Baltic amber. GZG.BST.27289. 2-4. Details showing tapering moniliform hyphae with distal dividing stages. 5. Phialides of Capnophialophora conidial state from Baltic amber; some phialides indicated by arrowheads. GZG.BST.27288, 6. Phragmoconidia of Capnosporium conidial state from Bitterfeld amber. GZG.BST.27291. Scale bars $100 \mu \mathrm{m}$ (a) and $10 \mu \mathrm{m}(\mathrm{b}-\mathrm{f})$. 
Menge assumed that the fossil would be related to extant lichens in the fruticose genera Sphaerophorus or Cornicularia (Lecanorales). As no apothecia were preserved in the fossil he avoided establishing a new genus and described it as Sphaerophorus moniliformis. Even in the species description Menge expressed doubts about its true affinity, especially as modern Sphaerophorus species do not produce minute, articulated thalli. He referred to the algae-like habit of the fossil and emphasized the moniliform, apically tapering filaments and cone-shaped tips, and concluded that it had grown as a hard crust on the conifer leaves. Plate 7 (1) (Plate 1 in Menge 1858) illustrates the tip of the Thuja twig with the attached fungus and also includes an enlarged detail showing branched and moniliform, apically tapering filaments. Some dividing apical cells can even be seen in the accurate drawing (Plate 7, 1). In the early $20^{\text {th }}$ century, Richard Klebs reported another obvious sooty mould from Baltic amber. The description and illustration of this organism appeared in the famous supplementary atlas of the Baltic amber flora of Caspary \& Klebs $(1906,1907)$. The newly found fossil matched Menge's earlier description perfectly (Plate 7, 2; Plate 9 in Caspary \& Klebs 1907), and again, this organism had grown attached to a Cupressaceae twig. The dark brown, globose or slightly flattened cells of the fossil were $8.5-11.4 \mu \mathrm{m}$ in size. While Klebs did not reinvestigate Menge's earlier specimen he did not believe that it nor the newly discovered fossil were fruticose lichens. Conversely, he identified them as dematiaceous hyphomycetes, in reference to two fossil Torula species that had been previously described by Caspary (1886). Based on Caspary's earlier descriptions Klebs named the newly found fossil Torula mengeanus.

Menge (1858) did not provide a collection number for the amber piece containing the twig with Sphaerophorus moniliformis, consequently this specimen is difficult to locate. Menge's amber collection was later housed in the West Prussian Provincial Museum in Danzig (Gdańsk). Whereas a major collection part comprising the arthropod inclusions was moved to central Germany in World War II (Krumbiegel \& Krumbiegel 2008), the inclusions of plants and fungi are obviously lost without any trace (Weitschat, pers. comm. 2012). Most pieces of the famous Künow collection, to which the historic specimens of Caspary's Torula species now belong, are housed at Berlin's Museum of Natural History (Museum für Naturkunde zu Berlin). Our recent reinvestigation of Caspary's specimens revealed that his two Torula species (Torula globulifera and T. heteromorpha) are not sooty moulds. Hence they will not be discussed here, but will be returned to in a separate paper. In the early $20^{\text {th }}$ century the amber piece containing the type specimen of Klebs' Torula mengeanus is known to have been in the private collection of Dr. Sommerfeld in Königsberg (Kaliningrad). Also this collection was later housed in the West Prussian Provincial Museum and subsequently moved to the geological-palaeontological collection of the Albertus University in Königsberg (Hinrichs 2007). We are unaware whether this fossil still exists. In any case, 

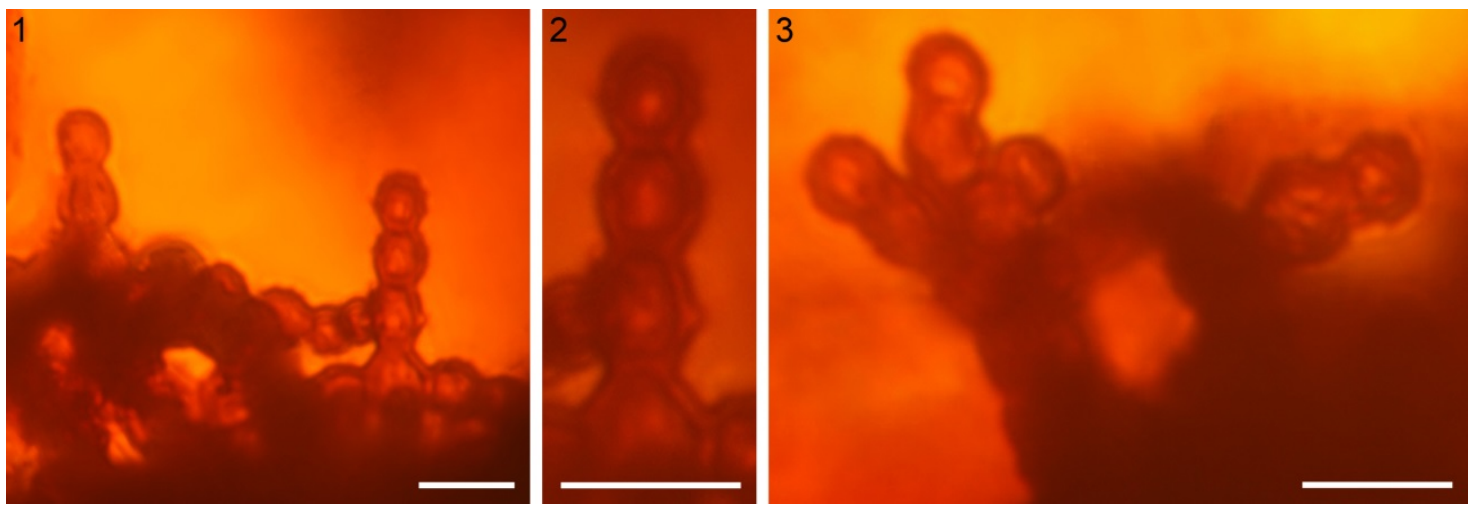

Plate 6. Sooty mould from Dominican amber MB.Pb.2009-348. 1-3. Moniliform, verrucose hyphae with right-angled branching. Scale bars $10 \mu \mathrm{m}$.

on the basis of the illustration (Plate 7,2 ), the fossil organism most probably was a metacapnodiaceous sooty mould.

While Sphaerophorus moniliformis Menge (1858) undoubtedly represents the first historical description of a Metacapnodium species in Baltic amber, we refrain from making a new combination since Menge's original specimen has been lost. Furthermore, an extant species with the name Metacapnodium moniliforme (L. R. Fraser) S. Hughes already exists. We rather recommend using Metacapnodium succinum as a fossil morphospecies for specimens in Baltic amber since this taxon is based on specimens in public collections.

1
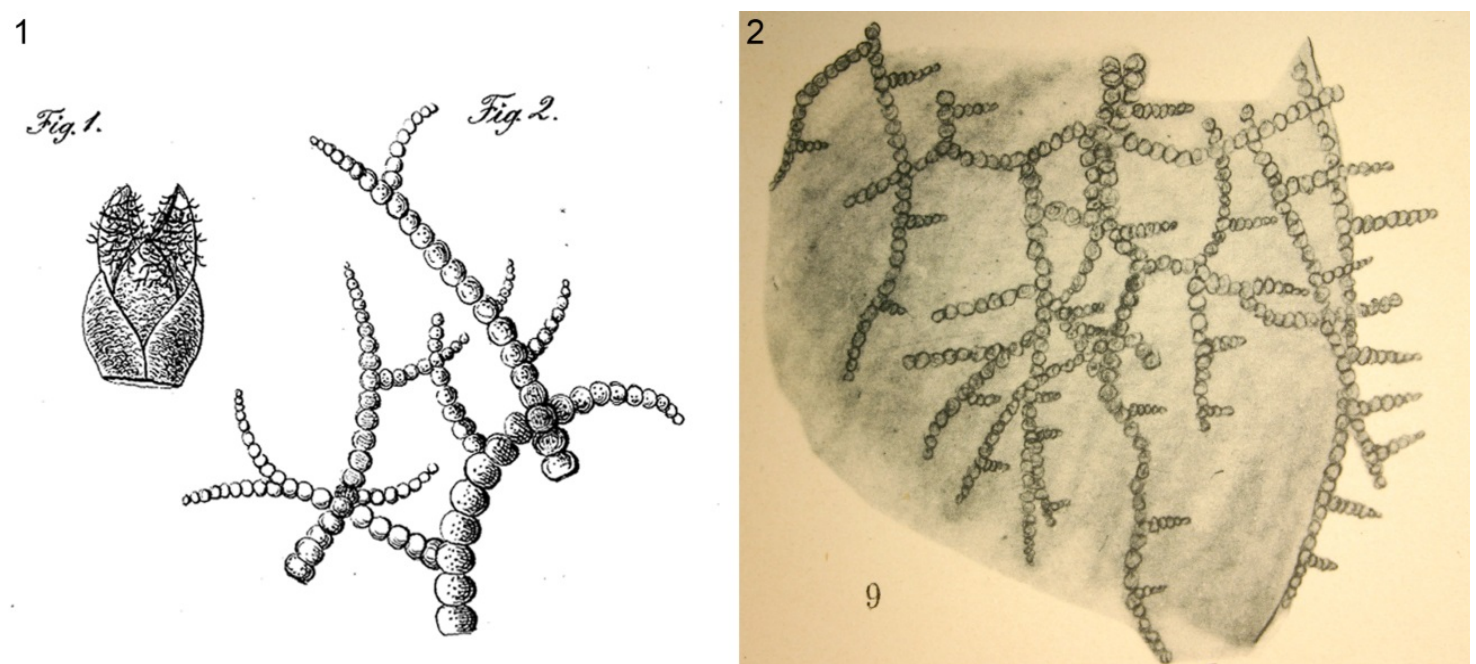

Plate 7. Historic drawings of metacapnodeaceous sooty moulds. 1. Sphaerophorus moniliformis Menge (1858). 2. Torula mengeanus Klebs (Caspary \& Klebs 1906, 1907). 


\section{Cretaceous to Miocene sooty moulds}

The Cretaceous ambers from Àlava, San Just (Spain) and Archingeay (France) provide the oldest fossils of sooty moulds discovered so far. While not all fungal remains in each amber piece necessarily belong to only one fungus, all the specimens include some fragments that can with some confidence be assigned to the Metacapnodiaceae in the Capnodiales (Plate 2, 1,2 and Plate 3). All these fungi have produced aerial, monilioid and apically tapering hyphae with wide-angled branching and smooth, globose to barrel-shaped cells. Young, dividing apical cells are seen in the Archingeay (Plate 2, 2) and San Just fossils (Plate 3, 3), and also hyphal anastomoses (Plate 3, 2) and a conidial state that could possibly be assigned to Capnobotrys (Plate 3, 6-9) have been preserved in the latter specimen. While bark remains and tracheids occur close to the extensive hyphal network in the Archingeay amber (Plate 2, 3-6), the network itself seems to have grown within an amorphous matrix and may even have formed a basal subiculum for the aerial hyphae with rounded cells (Plate 2, 2).

The minute Traunsee amber fossils (Plate 2, 7) also appear to represent moniliform hyphae, rather than conidial chains. While they may also represent sooty moulds in the wide sense, they cannot be assigned to any one lineage. The same applies to some other Cretaceous fossils mentioned in earlier studies. For example, while describing a Cretaceous liverwort from Myanmar amber, Hentschel et al., (2009) also reported monilioid dematiaceous fungi growing on the leaf surface of the bryophyte (Plate 4 in Hentschel et al., 2009). Recent closer preparation of the potential sooty moulds mentioned by Schmidt et al., (2010a) from Cenomanian amber of Ethiopia revealed that these fossils are more likely to represent verrucose conidial chains than hyphae of sooty moulds.

The Lower Eocene Oise amber from the Paris Basin has provided the oldest Paleogene sooty mould fossils. They consist of short moniliform, apically tapering hyphal fragments attached to the cuticle of a thrips of the genus Uzelothrips ( $\mathrm{Nel}$ et al., in press). Also phragmoconidia similar to those produced by extant Capnosporium species (anamorphic Metacapnodiaceae) have been preserved.

Fossils of the Metacapnodiaceae from Middle to Late Eocene Baltic and Late Oligocene Bitterfeld amber were already described by Rikkinen et al., (2003). The taxon Metacapnodium succinum was established for the metacapnodiaceous sooty moulds known from these amber deposits as a new combination based on the previously described Rosaria succina Dörfelt, A. R. Schmidt et Wunderl. ('Cyanobacteria') from Baltic amber (Dörfelt et al., 2000). The extant genus Rosaria was described by Nellie Carter in 1922 on the basis of a 'peculiar and beautiful alga which looks like a string of glistening pearls under the low power of the microscope' from a tree trunk on Mt. 
Canala in New Caledonia. Since then, the genus Rosaria has been illustrated in the cyanobacteria literature. Carter's drawing of the original description of $R$. ramosa actually suggests a typical metacapnodiaceous hyphal morphology with respect to shape and size of the cells, tapering filaments with bottle-shaped apical dividing stages and the dark appearance of the filaments. Reinvestigation of the decrepit type specimen of Rosaria ramosa by Rikkinen et al., (2003) indicated that $R$. ramosa could also have been a eukaryotic alga, possibly a terrestrial taxon close to Physolinum monilia (De Wildem.) Printz of the Trentepohliales (Chlorophyta).

The dematiaceous fungi from Dominican amber are difficult to study and illustrate because of their placement between liverwort leaves. While these fungi may represent sooty moulds at least in the wide sense, they cannot be assigned with confidence to any particular group (Plate 6).

\section{Palaeoecology and evolution}

Most if not all major amber deposits originate from lowland or coastal forests from which the resins were re-deposited into fluvial or shallow marine near-shore sedimentary basins (e.g., Vonk \& Schram 2007; Girard et al., 2008, 2009a, b; Perrichot \& Girard 2009). Resin, whether fresh or fossilized, is so soft that large amounts could hardly have survived the high-energy process of erosion, transport and deposition from the inland and from mountain ranges (Schmidt et al., 2001). Most sooty moulds described here probably grew epiphytically on the bark or leaves of the amberproducing or neighboring trees. Others lived as hyperepiphytes on corticolous lichens and bryophytes. Also extant sooty moulds can occasionally colonize surfaces of larger cryptogamic epiphytes (e.g. Braun et al., 2009). The ancient fungi may have got stuck in resin when it exuded over bark or when fragments of fungal subicula became detached and dropped onto fresh resin on the tree trunk or forest floor. The sooty moulds preserved in the different amber deposits most probably grew on different trees. The presence of these fungi in ambers indicates a certain degree of humidity in the ancient forests from which the fossils resins derive. Cretaceous forests even in the tropics probably received less rainfall than modern angiosperm-dominated rainforests (Boyce et al., 2010). However, the fossil sooty moulds from mid-Cretaceous ambers suggest that the coastal 'amber forests' were likely to receive additional moisture in the form of frequent coastal fog or local rainfall.

Conifers of the Araucariaceae and Cheirolepidiaceae are the likely resin-producers

of the Early Cretaceous French (Archingeay) and Spanish (Àlava, San Just) ambers (Peñalver \& Delclòs 2010). These conifers grew in mixed forests with Podocarpaceae and early angiosperms (Perrichot et al., 2007) in estuarine environments in a warm, wet 
but seasonal subtropical climate (Perrichot et al., 2007, 2010). The botanical origin of Traunsee amber remains unclear; it most likely derived from a conifer resin (Vávra 2005).

The Lower Eocene Oise amber was probably produced by a Daniellia-like or Hymenaea-like plant in the Detarieae of the Fabaceae family (De Franceschi \& De Ploëg 2003; Jossang et al., 2008) or by a Terminalia-like taxon of the Combretaceae (Nel \& Brasero 2010). Very few plant or fungal inclusions have been found in this resin from a deltaic gallery-forest in a warm, paratropical climate with contrasting wet and dry seasons ( $\mathrm{Nel} \&$ Brasero 2010). However, this ancient angiosperm resin recently provided fossil evidence of fungus-animal association which still exists today (Nel et al., in press). The sole extant species of the monogeneric thrips family Uzelothripidae (Thysanoptera), Uzelothrips scabrosus, has been collected from leaf litter and from bark in the Palaeotropics and Neotropics. The thrips appear to use the sooty moulds both as their microhabitat and as a food source, and hyphal fragments are often seen attached to their cuticles. Additionally, one of the two known fossil specimens of Uzelothrips eocenicus from Oise amber has moniliform hyphae of capnodialean sooty moulds on its cuticle ( $\mathrm{Nel}$ at al. in press). The fossil thrips is distinguished from the extant species only by the absence of the fusion of two antennal segments. Thus, this insect genus, like accompanying sooty moulds, shows a remarkable morphological stability. This shared stability of uzelothripids and sooty moulds could be partly explained by the long-term ecological stability of their specialized habitat, resulting in limited selection pressure.

The Baltic amber derives from Middle or Late Eocene warm-temperate forests with conifers such as Cupressaceae, Pinaceae and Sciadopitaceae, and angiosperms including many species of Aceracae, Fagaceae (evergreen oaks), Lauraceae, Magnoliaceae and Pittosporaceae (Kohlman-Adamska 2001). Many extant species of Pinaceae produce large amounts of resin and a plethora of macrofossils of this family is preserved in Baltic amber. However, Pinaceae resins are not likely to turn into amber since they are not polymerized and thus degrade easily (Beck 1993). Based on chemical analyses, Wolfe et al., (2009) suggested that Sciadopitys would be the most likely source of Baltic amber. Identifiable substrates of Metacapnodium succinum from Baltic amber have so far included Cupressaceae twigs (Menge 1858, Caspary \& Klebs 1907, see Plate 7, 1) and a foliose lichen (Rikkinen et al., 2003). Furthermore, an amber piece of the Arnold collection shows an 'imprint' of a leaf that had possessed stellate hairs (likely an evergreen oak). These hairs were surrounded by the fresh resin whereas the leaf blade itself dropped off before a further resin flow enclosed everything. Underneath a stellate hair there is a branched Metacapnodium hypha, suggesting that the fungus had grown on the surface of the oak leaf.

One specimen of Metacapnodium succinum (GZG.BST.27292) in Bitterfeld amber was found attached to a piece of bark. The Late Oligocene amber derives from coastal 
forests from which Cupressaceae such as Cryptomeria sp., Cupressospermum saxonicum Mai and Taiwania, Pinaceae as well as the angiosperm genera Quercus (Fagaceae) and Liquidambar (Hamamelidaceae) were described (Barthel \& Hetzer 1982; Jähnichen 1998).

Finally, the Dominican amber derives from a highly diverse Caribbean tropical rainforest, and the Fabaceae representative Hymenaea protera Poinar was identified as the resin-bearing tree. Possibly, the epiphytic liverwort on which the sooty mould grew was an epiphyte of a resinous Hymenaea tree (see Penney 2010).

The Early Cretaceous fossils from Àlava, San Just and Archingeay demonstrate the capnodialean sooty moulds have occupied epiphytic habitats for at least 110 million years. This was when early angiosperms rapidly diversified in forest ecosystems (Crane 1987). The rise of angiosperms to dominance may have favored sooty moulds for at least two reasons. First, the transpiration capacity of broad-leaved angiosperms with a high leaf vein density is much higher than that of gymnosperms or any spore plants which dominated terrestrial ecosystems until the Early Cretaceous. Thus, flowering plants likely strongly altered the climate by means of increasing humidity and rainfall, especially in tropical ecosystems where recycling of transpired water is well known to be an important source of rainfall (Boyce et al., 2010). In addition, the tremendous increase of broad-leaved plant species in forest ecosystems since about 100 million years ago also provided additional food sources and microhabitats for plant sap sucking insects such as aphids and scale insects, and consequently also suitable niches for sooty moulds (Rikkinen et al., 2003).

The morphological similarity of some Early Cretaceous sooty moulds to extant taxa suggests an even longer evolutionary history and indicates that capnodialean sooty moulds might represent a very ancient component of humid forest ecosystems. Insect excretions such as honey dew as potential nutrition source were available much earlier than the Cretaceous as the oldest aphid record is Middle Triassic in age (Szwedo \& Nel 2011) and hemipterans and palaeodictyopterans with sucking beaks are known from the Carboniferous (Labandeira 2006; Nel et al., 2012). Crous et al., (2009) suggested that the ancestral nutritional mode of capnodelean fungi would have been saprobic, since saprobic genera represent the earliest diverging lineages among the extant taxa. Similar suggestions have been made concerning many other lineages in the larger context of Ascomycota (Schoch et al., 2009). Hence, the association between plant-sucking insects and sooty moulds may already have evolved in pre-Cretaceous times. No sooty moulds have so far been recorded from the Berriasian to Aptian Lebanese amber or from older ambers. However, Jurassic ambers are typically found only in trace quantities and only one Triassic amber deposit has so far produced any fossilized organisms (Schmidt et al., 2006, 2012). Thus, the lack of pre-Cretaceous sooty mould fossils may well be a 
sampling artifact related to the very limited amounts of surviving amber and the highly unlikely preservation of any fungal fossils inside such resins.

\section{Conclusions}

Sooty moulds are recorded as amber fossils from about 110 million years ago, and the hyphal morphology of some Cretaceous specimens is indistinguishable from extant and Paleogene species of the family Metacapnodiaceae (Dothideomycetes). The morphological proximity of some Early Cretaceous specimens to extant taxa suggests an ancient history for this group of epiphytic saprophytes. The fossils derive from several distinct types of intertropical to warm-temperate 'amber forests', but they all indicate a certain degree of humidity in these palaeoecosystems.

\section{Acknowledgments}

We would like to thank Rafael López Del Valle (Vitoria-Gasteiz) and Christian Neumann (Berlin) for providing access to museums collections. We are grateful to Volker Arnold (Heide, Germany) for donating Baltic and Bitterfeld amber pieces and to Wolfgang Bieri (Binn, Switzerland) for donating the piece of Dominican amber. We are indebted to David Dilcher (Bloomington), Didier Néraudeau (Rennes) and Carmen Soriano (Grenoble and Barcelona) for guidance during field work and to Kerstin Schmidt (Jena) and Wolfgang Weitschat (Hamburg) for discussion. Melanie Muschalla (Göttingen) discovered inclusions in field-collected amber pieces from San Just. Norbert Vávra (Vienna) and Michael Wagreich (Vienna) kindly provided unpublished data about the age of the Traunsee amber. The Berlin State Library permitted copying the illustration used for Plate 7 (2). This work was partly supported by the Alexander von Humboldt Foundation through a 2006-2007 research fellowship to V.P. This is a contribution to the program Interrvie (research project NOVAMBRE to Didier Néraudeau, University Rennes 1) from the French Institute for Universe Sciences (CNRS-INSU). This is publication number 110 from the Courant Research Centre Geobiology, funded by the German Initiative of Excellence. 


\section{References}

Azar, D., Perrichot, V., Néraudeau, D., Nel, A., 2003. New psychodids from the Cretaceous ambers of Lebanon and France, with a discussion of Eophlebotomus connectens Cockerell, 1920 (Diptera, Psychodidae). Annals of the Entomological Society of America 96, 117-126.

Barthel, M., Hetzer, H., 1982. Bernstein-Inklusen aus dem Miozän des Bitterfelder Raumes. Zeitschrift für Angewandte Geologie 28, 314-336.

Beck, C.W., 1993. Der Wissensstand über chemische Struktur und botanische Herkunft des Bernsteins. In: Roznowski, F. (Ed.), Miscellanea archaeologica Thaddaeo Malinowski dedicata qua Franciscus Roznowski redigendum curavit. Stupsk, Poznan, pp. 27-38.

Blumenstengel, H., 2004. Zur Palynologie und Stratigraphie der Bitterfelder Bernsteinvorkommen (Tertiär). Exkursionsführer und Veröffentlichung der Deutschen Gesellschaft für Geowissenschaften 224, 17.

Blumenstengel, H., Volland, L., Krutzsch, W., 1999. Zur Stratigraphie und Fazies des Tertiärs im Bitterfelder Raum - Referenzprofile tertiärer Ablagerungen in den Tagebauen Goitsche, Golpa-Nord und Göbern. Geologisches Landesamt SachsenAnhalt, Halle.

Boyce, C.K., Lee, J.E., Feild, T.S., Brodribb, T.J., Zwieniecki, M.A., 2010. Angiosperms helped put the rain in the rainforests: The impact of plant physiological evolution on tropical biodiversity. Annals of the Missouri Botanical Garden 97, $527-$ 540.

Braun, U., Heuchert, B., Diederich, P., 2009. Two new and another interesting lichenicolous hyphomycete. Herzogia 22, 165-171.

Carter, N., 1922. Freshwater algae. In: Compton, R.H. (Ed.), A systematic account of the plants collected in New Caledonia and the Isle of Pines in 1914. - Part III. Cryptogams (Hepaticae - Fungi). Journal of the Linnean Society London 44, 47-68.

Caspary, R., 1886. Einige neue Pflanzenreste aus dem Samländischen Bernstein. Schriften der physikalisch -ökonomischen Gesellschaft zu Königsberg 27, 1-8.

Caspary, R., Klebs, R. 1906. Die Flora des Bernsteins und anderer fossiler Harze des ostpreussischen Tertiärs. Abhandlungen der Königlich Preußischen Geologischen Landesanstalt, Berlin.

Caspary, R., Klebs, R., 1907. Atlas von dreissig Tafeln zu der Abhandlung: Die Flora des Bernsteins und anderer fossiler Harze des ostpreussischen Tertiärs. Abhandlungen der Königlich Preußischen Geologischen Landesanstalt, Berlin.

Cheewangkoon, R., Groenewald, J.Z., Summerell, B.A., Hyde, K.D., To-anun, C., Crous, P.W., 2009. Myrtaceae, a cache of fungal biodiversity. Persoonia 23, 55-85. 
Chomnunti, P., Schoch, C.L., Aguirre-Hudson, B., Ko-Ko, T.W., Hongsanan, S., Jones, E.B.G., Kodesub, R., Phookamsak, R., Chukeatorote, E., Bahkali, A.H., Hyde, K.D. 2011. Capnodiaceae. Fungal Diversity 51, 103-134.

Chomnunti, P., Bhat, D.J., Gareth Jones, E.B., Chukeatirote, E., Bahkali, A.H., Hyde, K.D., 2012a. Trichomeriaceae, a new sooty mould family of Chaetothyriales. Fungal Diversity 56, 63-76.

Chomnunti, P., Ko Ko, T.W., Chukeatirote, E., Cai, L., Jones, E.B.G., Kodsueb, R., Chen, H., Hassan, B.A., Hyde, K.D. 2012b. Phylogeny of Chaetothyriaceae in northern Thailand including three new species. Mycologia 104, 382-395.

Crane, P.R., 1987. Vegetational consequences of the angiosperm diversification. In: Friis, E.M., Chaloner, W.G., Crane, P.R. (Eds.), The origins of angiosperms and their biological consequences. Cambridge University Press, Cambridge, pp. 107-144.

Crous, P.W., Schoch, C.L., Hyde, K.D., Wood, A.R., Gueidan, C., de Hoog, G.S., Groenewald, J.Z. 2009. Phylogenetic lineages in the Capnodiales. Studies in Mycology 64, 17-47.

De Franceschi, D., De Ploëg, G., 2003. Origine de l'ambre des faciès sparnaciens (Éocène inférieur) du Bassin de Paris: le bois de l'arbre producteur. Geodiversitas $25,633-647$.

Dörfelt, H., Schmidt, A.R., Wunderlich, J, 2000. Rosaria succina spec. nov. - a fossil cyanobacterium from Tertiary amber. Journal of Basic Microbiology 40, 311-316.

Dunlop, J.A. 2010. Bitterfeld amber. In: Penney, D. (Ed.), Biodiversity of fossils in amber from the major world deposits, Siri Scientific Press, Manchester, pp. 57-68.

Girard. V., Schmidt, A.R., Saint Martin, S., Struwe, S., Perrichot, V., Saint Martin, J.P., Grosheny, D., Breton, G., Néraudeau, D., 2008. Evidence for marine microfossils form amber. Proceedings of the National Academy of Sciences USA 105, 1742617429.

Girard, V., Schmidt, A.R., Struwe, S., Perrichot, V., Breton, G., Néraudeau, D. 2009a. Taphonomy and palaeoecology of mid-Cretaceous amber-preserved microorganisms from southwestern France. In: Perrichot, V., Néraudeau, D. (Eds.), Cretaceous ambers from southwestern France: Geology, taphonomy, and palaeontology. Geodiversitas 31, 153-162.

Girard, V., Saint Martin, S., Saint Martin, J.-P., Schmidt, A.R., Struwe, S., Perrichot, V., Breton, G., Néraudeau, D., 2009b. Exceptional preservation of marine diatoms in upper Albian amber. Geology 37, 83-86.

Faull, J.L., Olejnik, I., Ingrouille, M., Reynolds, D., 2002. A reassessment of the taxonomy of some tropical sooty moulds. Tropical Mycology 2, 33-40.

Heinrichs, J., Schmidt, A.R., 2010. An inclusion of Frullania subgen. Diastaloba s.1. (Frullaniaceae, Porellales) in Dominican amber. Tropical Bryology 31, 91-94. 
Hentschel, J., Schmidt, A.R., Heinrichs, J., 2009. Frullania cretacea sp. nov. (Porellales, Jungermanniopsida), a leafy liverwort preserved in Cretaceous amber from Myanmar. Cryptogamie Bryologie 30, 323-328.

Hinrichs, K., 2007. Bernstein, das "Preußische Gold" in Kunst- und Naturalienkammern und Museen des 16. - 20. Jahrhunderts. Dissertation, Humboldt University Berlin

Hradecká, L., Kvacek, J., Lobitzer, H., Schuster, R., Svobodá, M., Szente, I., Svabenicka, L. 2004/2005. Blatt 65 Mondsee. Bericht 2004/2005 über fazielle und biostratigraphische Untesuchungen von Gosau-Vorkommen im Salzkammergut zwischen St. Gilgen am Wolfgangsee und dem Traunsee. Geologische Bundesanstalt, Wien.

Hughes, S.J., 1976. Sooty moulds. Mycologia 68, 693-820.

Hughes, S.J., 2003. Capnofrasera dendryphioides, a new genus and species of sooty moulds. New Zealand Journal of Botany 41, 139-146.

Hughes, S.J., 2007. Heteroconium and Pirozynskiella n. gen., with comments on conidium transseptation. Mycologia 99, 628-638.

Iturralde-Vinent, M.A., 2001. Geology of the amber-bearing deposits of the Greater Antilles. Caribbean Journal of Science 37, 141-167.

Iturralde-Vinent, M,A., Mac Phee, R.D.E., 1996. Age and paleogeographical origin of Dominican amber. Science 273, 1850-1852.

Jähnichen, H., 1998. Erstnachweis von Taiwania, Cryptomeria und Liquidambar aus demBitterfelder und Baltischen Bernstein. Mitteilungen aus dem Museum für Naturkunde in Berlin, Geowissenschaften 1, 167-178.

Jossang, J., Bel-Kassaoui, H., Jossang, A., Seuleiman, M., Nel, A., 2008. Quesnoin, a novel pentacyclic ent-diterpene from 55 million years old Oise amber. The Journal of Organic Chemistry 73, 412-417.

Kirk, P.M., Cannon, P.F., Minter, D.W., Stalpers, J.A., 2008. Dictionary of the Fungi, 10th ed, Cromwell Press, Trowbridge.

Kohlman-Adamska, A., 2001. A graphic reconstruction of an "amber" forest. In: Kosmowska-Ceranowicz, B. (Ed.), The amber treasure trove: Part 1. The Tadeusz Giecewicz's collection at the Museum of the Earth, Polish Academy of Sciences. Oficyna Wydawnicza Sadyba, Warsaw, pp. 15-18.

Krumbiegel, G., Krumbiegel, B. 2008. Die Danziger Bernsteininklusen-Sammlung von Otto Helm und Anton Menge auf dem Weg nach Thüringen - eine Spurensuche. Abhandlungen und Berichte des Museums der Natur Gotha 25, 13-16.

Labandeira, C.C., 2006. The four phases of plant-arthropod associations in deep time. Geologica Acta 4, 409-438.

Lumbsch, H.T., Huhndorf, S.M., 2010. Myconet Volume 14. Part One. Outline of Ascomycota-2009. Fieldiana Life and Earth Science 1, 1-60. 
Menge, A. 1858. Beitrag zur Bernsteinflora. Schriften der Naturforschenden Gesellschaft in Danzig 5, 1-18.

Nel, A., Brasero, N. 2010. Oise amber. In: Penney, D. (Ed.), Biodiversity of fossils in amber from the major world deposits. Siri Scientific Press, Manchester, pp. 137-148.

Nel, A., Prokop, J., Nel, P., Grandcolas, P., Huang, D.Y., Roques, P., Guilbert, E., Dostál, O., Szwedo, J. 2012. Traits and evolution of wing venation pattern in paraneopteran insects. Journal of Morphology 273, 480-506.

Nel, P., Schmidt, A.R., Bässler, C., Nel, A., (in press) Fossil thrips of the Uzelothripidae family suggest 53 million years of morphological and ecological stability. Acta Palaeontol Pol doi:10.4202/app.2011.0077.

Néraudeau, D., Perrichot, V., Dejax, J., Masure, E., Nel, A., Philippe, M., Moreau, P., Guillocheau, F., Guyot, T., 2002. Un nouveau gisement à ambre insectifère et à végétaux (Albien terminal probable): Archingeay (Charente-Maritime, France). Geobios 35, 233-240.

Ortega-Blanco J., Delclòs, X., Engel, M.S., 2011. Diverse stigmaphronid wasps in Early Cretaceous amber from Spain (Hymenoptera: Ceraphronoidea: Stigmaphronidae). Cretaceous Research 32, 762-773.

Peñalver, E., Delclòs, X., Soriano, C., 2007. A new rich amber outcrop with palaeobiological inclusions in the Lower Cretaceous of Spain. Cretaceous Research 28, 791-802.

Peñalver, E., Delclòs, X., 2010. Spanish amber. In: Penney, D. (Ed.), Biodiversity of fossils in amber from the major world deposits. Siri Scientific Press, Manchester, pp. $236-270$.

Penney ,D., 2010. Dominican amber. In: Penney, D. (Ed.), Biodiversity of fossils in amber from the major world deposits. Siri Scientific Press, Manchester, pp. 22-41.

Perrichot, V., Girard, V. 2009. A unique piece of amber and the complexity of ancient forest ecosystems. Palaios 24, 137-139.

Perrichot, V., Néraudeau, D., Nel, A., De Ploëg, G. 2007. A reassessment of the Cretaceous amber deposits from France and their palaeontological significance. African Invertebrates 48, 213-227.

Perrichot, V., Néraudeau, D., Tafforeau, P., 2010. Charentese amber. In: Penney, D. (Ed.), Biodiversity of fossils in amber from the major world deposits. Siri Scientific Press, Manchester, pp. 192-207.

Reynolds, D.R., 1986. Foliicolous ascomycetes 7. Phylogenetic systematics of the Capnodiaceae. Mycotaxon 27, 377-403.

Reynolds, D.R. 1998. Capnodiaceous sooty mold phylogeny. Canadian Journal of Botany 76, 2125-2130. 
Rikkinen, J., Dörfelt, H., Schmidt, A.R., Wunderlich, J., 2003. Sooty moulds from European Tertiary amber, with notes on the systematic position of Rosaria (Cyanobacteria). Mycological Research 107, 251-256.

Schmidt, A.R., Dilcher, D.L., 2007. Aquatic organisms as amber inclusions and examples from a modern swamp forest. Proceedings of the National Academy of Sciences USA 104, 16581-16585.

Schmidt, A.R., Schäfer, U., 2005. Leptotrichites resinatus new genus and species, a fossil sheathed bacterium in alpine Cretaceous amber. Journal of Paleontology 79, 184-193.

Schmidt, A.R., von Eynatten, H., Wagreich, M. 2001. The Mesozoic amber of Schliersee (southern Germany) is Cretaceous in age. Cretaceous Research 22, 423-428.

Schmidt, A.R., Ragazzi, E., Coppellotti, O., Roghi, G., 2006. A microworld in Triassic amber. Nature 444, 835.

Schmidt, A.R., Perrichot, V., Svojtka, M., Anderson, K.B., Belete, K.H., Bussert, R., Dörfelt, H., Jancke, S., Mohr, B., Mohrmann, E., Nascimbene ,P.C., Nel, A., Nel, P., Ragazzi, E., Roghi, G., Saupe, E.E., Schmidt, K., Schneider, H., Selden, P.A., Vávra, N,. 2010a. Cretaceous African life captured in amber. Proceedings of the National Academy of Sciences USA 107, 7329-7334.

Schmidt, A.R., Girard, V., Perrichot, V., Schönborn, W. 2010b. Testate amoebae from a Cretaceous forest floor microbiocoenosis of France. Journal of Eukaryotic Microbiology 57, 245-249.

Schmidt, A.R., Jancke, S., Lindquist, E.E., Ragazzi, E., Roghi. G., Nascimbene, P.C., Schmidt, K., Wappler, T., Grimaldi, D.A. 2012. Arthropods in amber from the Triassic Period. Proceedings of the National Academy of Sciences USA 109, 1479614801.

Schoch, C.L., Crous, P.W., Groenewald, J.Z., Boehm, E.W., Burgess, T.I., de Gruyter, J., de Hoog, G.S., Dixon, L.J., Grube, M., Gueidan, C., Harada, Y., Hatakeyama, S., Hirayama, K., Hosoya, T., Huhndorf, S.M., Hyde, K.D., Jones, E.B., Kohlmeyer, J., Kruys, A., Li, Y.M., Lucking, R., Lumbsch, H.T., Marvanova. L., Mbatchou. J.S., McVay, A.H., Miller, A.N., Mugambi, G.K., Muggia, L., Nelsen, M.P., Nelson, P., Owensby, C.A., Phillips, A.J., Phongpaichit, S., Pointing. S.B., Pujade-Renaud, V., Raja, H.A., Plata, E.R., Robbertse, B., Ruibal, C., Sakayaroj. J., Sano. T., Selbmann, L., Shearer, C.A., Shirouzu, T., Slippers, B., Suetrong, S., Tanaka, K., VolkmannKohlmeyer, B., Wingfield, M.J., Wood, A.R., Woudenberg, J.H., Yonezawa, H., Zhang, Y., Spatafora, J.W., 2009. A class-wide phylogenetic assessment of Dothideomycetes. Studies in Mycology 64, 1-15.

Seifert, K., Morgan-Jones, G., Gams, W., Kendrick, B., 2011. The genera of the Hyphomycetes. CBS-KNAW Fungal Biodiversity Centre, Utrecht. 
Standke, G., 1998. Die Tertiärprofile der Samländischen Bernsteinküste bei Rauschen. Schriftenreihe für Geowissenschaften 7, 93-133.

Sugiyama, J., Amano, N., 1987. Two metacapnodiaceous sooty moulds from Japan: their identity and behavior in pure culture. In: Pleomorphic fungi: the diversity and its taxonomic implications. Kodansha, Tokyo, pp. 141-156.

Szwedo, J., Nel, A. 2011. The oldest aphid insect from the Middle Triassic of the Vosges, France. Acta Palaeontologica Polnica 56, 757-766.

Vávra, N., 2005. Bernstein und verwandte Organische Minerale aus Österreich. Beiträge zur Paläontologie 29, 255-280.

Vonk, R., Schram, F.R., 2007. Three new tanaid species (Crustacea, Percarida, Tanaidacea) from the Lower Cretaceous Álava amber in Northern Spain. Journal of Paleontology 81, 1502-1509.

Wolfe, A.P., Tappert, R., Muehlenbachs, K., Boudreau, M., McKellar, R.C., Basinger, J.F., Garrett, A., 2009. A new proposal concerning the botanical origin of Baltic amber. Proceedings of the Royal Society B 276, 3403-3412. 
Appendix 5

\section{Appendix 5}

Beimforde C, Schäfer N, Dörfelt H, Nascimbene PC, Singh H, Heinrichs J, Reitner J, Rana RS, Schmidt AR (2011). Ectomycorrhizas from a Lower Eocene angiosperm forest. New Phytologist. 192: 988-996.

Impact factor of New Phytologist for 2011: 6.645, according to Journal Citation Reports 


\title{
Ectomycorrhizas from a Lower Eocene angiosperm forest
}

\author{
Christina Beimforde ${ }^{1}$, Nadine Schäfer ${ }^{1}$, Heinrich Dörfelt ${ }^{2}$, Paul C. Nascimbene ${ }^{3}$, \\ Hukam Singh ${ }^{4}$, Jochen Heinrichs ${ }^{5}$, Joachim Reitner ${ }^{1}$, Rajendra S. Rana ${ }^{6}$ and \\ Alexander R. Schmidt ${ }^{1}$
}

${ }^{1}$ Courant Research Centre Geobiology, Georg-August-Universität Göttingen, Goldschmidtstraße 3, 37077 Göttingen, Germany; ${ }^{2}$ Mikrobielle Phytopathologie, Friedrich-Schiller-Universität, Neugasse 25, 07743 Jena, Germany; ${ }^{3}$ Division of Invertebrate Zoology, American Museum of Natural History, 79th Street at Central Park West, New York, NY 10024, USA; ${ }^{4}$ Birbal Sahni Institute of Palaeobotany, 53 University Road, Lucknow 226007, India; ${ }^{5}$ Albrecht-von-Haller-Institut für Pflanzenwissenschaften, Abteilung Systematische Botanik, Georg-August-Universität Göttingen, Untere Karspüle 2, 37073 Göttingen, Germany; ${ }^{6}$ Department of Geology, Hemwati Nandan Bahuguna Garhwal University, Srinagar 246174, India

Corresponding author: Alexander R. Schmidt: (alexander.schmidt@geo.uni-goettingen.de) 


\begin{abstract}
The development of mycorrhizal associations is considered a key innovation that enabled vascular plants to extensively colonize terrestrial habitats. Here, we present the first known fossil ectomycorrhiza from an angiosperm forest. Our fossils are preserved in a 52 million-year-old piece of amber from the Tadkeshwar Lignite Mine of Gujarat State, western India. The amber was produced by representatives of Dipterocarpaceae in an early tropical broadleaf forest. The ectomycorrhizas were investigated using light microscopy and field emission-scanning-electron microscopy. Dissolving the amber surrounding one of the fossils allowed ultrastructural analyses and Raman spectroscopy. About 20 unramified, cruciform and monopodial-pinnate ectomycorrhizas are fossilized adjacent to rootlets, and different developmental stages of the fossil mycorrhizas are delicately preserved in the ancient resin. Compounds of melanins were detectable in the dark hyphae. The mycobiont, Eomelanomyces cenococcoides gen. et spec. nov., is considered to be an ascomycete; the host is most likely a dipterocarp representative. An early ectomycorrhizal association may have conferred an evolutionary advantage on dipterocarps. Our find indicates that ectomycorrhizas occurred contemporaneously within both gymnosperms (Pinaceae) and angiosperms (Dipterocarpaceae) by the Lower Eocene.
\end{abstract}

Key words: amber, ascomycetes, Dipterocarpaceae, India, mycorrhizas, melanin 


\section{Introduction}

Mycorrhizas are ubiquitous in terrestrial ecosystems. Up to $90 \%$ of all vascular plants live in a mutualistic association with fungi (Malloch et al., 1980). One selective advantage of mycorrhizal symbioses is an increase in the plant's uptake of phosphorus and nitrogen. Additionally, some fungal partners protect plants against droughts and diseases such as microbial soil-borne pathogens. At the same time, the fungus gets a relatively constant and direct access to carbohydrates. This symbiotic relationship is considered to be a key innovation of early land plants that enabled them to extensively colonize terrestrial habitats (e.g. Cairney, 2000; Wang et al., 2010).

Various classes of mycorrhizas have evolved over the course of time (Brundrett, 2002). Arbuscular endomycorrhizas are the oldest and most abundant ones (Cairney, 2000) and are recorded since the Early Devonian (Remy et al., 1994). Presently, more than $70 \%$ of all angiosperms build such endomycorrhizal associations, while only $2 \%$ build ectomycorrhizal ones (Brundrett, 2009). Within the gymnosperms, ectomycorrhizas are only known from Pinaceae and from the genus Gnetum (Brundrett, 2009).

The evolution of different classes of mycorrhizas was influenced not only by changing environmental conditions, but also by the appearance of possible new fungal symbionts (Cairney, 2000; Hibbett \& Matheny, 2009). Genes required for the formation of arbuscular mycorrhizas have been found in all embryophyte lineages (Wang et al., 2010). This suggests that early land plants had the potential to form arbuscular endomycorrhizas, and that extant plants that do not form this kind of mycorrhiza have either lost or suppressed the genes involved.

Several studies suggest that various ectomycorrhizas evolved independently, at least once in the Pinaceae, and additionally in several disparate lineages of angiosperms (Fitter \& Moyersoen, 1996; Hibbett \& Matheny, 2009). However, the geographic origins and subsequent spread of ectomycorrhizal associations are still unclear. Since ectomycorrhizas are most widespread today in boreal and temperate forests, Alexander (2006) addressed the question of whether ectomycorrhizal associations arose in these environments, and only later moved into tropical latitudes, or if ectomycorrhizas arose independently in the tropics. Until now, the only fossil evidence for ectomycorrhizas had been reported from the roots of Eocene Pinaceae on Vancouver Island (LePage et $a l ., 1997)$, and these fossils may suggest an origin for ectomycorrhizas in the northern latitudes.

Here, we present the first fossil evidence of ectomycorrhizas from an early tropical rain forest that has Gondwanan affinities. The fossil ectomycorrhizas are enclosed in Early Eocene (52 million-year-old) Indian amber that was produced by a tropical 
angiosperm tree of the family Dipterocarpaceae (Rust et al., 2010). The Indian amber's chemistry is quite distinct from that of most other fossil resins, and it is weakly crosslinked by comparison (Dutta et al., 2009; 2011; Mallick et al., 2009). For this reason, we were able to dissolve the amber surrounding one mycorrhizal system and to apply ultrastructural analyses to the ectomycorrhiza's surface. Raman spectroscopy revealed compounds of melanins in the dark hyphae.

\section{Material and Methods}

Amber piece no. TAD 248 was found in situ in the Tadkeshwar Lignite Mine of Gujarat State, western India, which outcrops Early Eocene shallow marine sediments. The amber-bearing strata have been assigned to the Ypresian (52 million years old) based on shark teeth, foraminiferans, and dinoflagellates (Rust et al., 2010).

The original $4 \times 3 \times 2 \mathrm{~cm}$ piece of amber was divided into two smaller pieces (TAD $248 \mathrm{a}$ and $\mathrm{b}$ ) in order to better access the inclusions. The amber pieces were ground and polished manually using a series of wet silicon carbide papers [grit from FEPA P 6004000 (25.8 $\mu \mathrm{m}$ to $5 \mu \mathrm{m}$ particle size), firm Struers] and examined under incident (Carl Zeiss Stemi 2000) and transmitted light microscopes (Carl Zeiss AxioScope A1) equipped with Canon 450D digital cameras. Sometimes incident and transmitted light were used simultaneously. Some images were obtained from several optical sections using the software package HeliconFocus 5.0 (Kharkov Ukraine) for a better illustration of the three-dimensional inclusions.

For scanning electron microscopy, a ca. $20 \mathrm{~mm}^{3}$ block containing an ectomycorrhizal system was removed from amber piece TAD 258a using a dental drill. The tiny amber block was placed on a microscopic slide and dissolved using several drops of a mixture of toluene and 70\% ethanol (10:1) as described by Rust et al. (2010). The remaining microfossils were washed several times with a few drops of $70 \%$ ethanol. The obtained fragments of the hyphal mantle were then placed on a carboncovered SEM-mount using a wet hair from a superfine brush, sputtered by gold/palladium ( 2 x 120 seconds at $20 \mathrm{~mA}, 10 \mathrm{~nm}$ coat thickness) using an Automatic Sputter Coater (Canemco Inc., Quebec, Canada) and examined under a field emission scanning-electron microscope (Carl Zeiss LEO 1530).

Raman spectra were recorded from extracted dark hyphae using a Horiba Jobin Yvon LabRam-HR 800 UV micro-Raman spectrometer. The spectrometer has a focal length of $800 \mathrm{~mm}$. For excitation, the $488 \mathrm{~nm}$ line of an Argon Ion Laser (IMA 106020B0S, Melles Griot, Carlsbad, CA, USA) with a laser power of $20 \mathrm{~mW}$ was used. The laser was dispersed by a $600 \mathrm{l} / \mathrm{mm}$ grating on a CCD detector with 1024 x 256 pixels, yielding a spectral resolution of $0.43 \mathrm{~cm}^{-1}$. An Olympus BX41 microscope equipped with an Olympus LMPlanF1 $100 \mathrm{x}$ objective with a numerical aperture of 0.8 
focused the laser light onto the sample. The confocal hole diameter was set to $100 \mu \mathrm{m}$. The acquisition time was varied between 10 and $300 \mathrm{~s}$ for a spectral range of $100-$ $5000 \mathrm{~cm}^{-1}$. By using different filters, the power of the laser was reduced to $0.1 \%, 10 \%$ and $50 \%$ of its original power at the laser exit. For calibration of the spectrometer, a silicon standard with a major peak at $520.4 \mathrm{~cm}^{-1}$ was used. All spectra were recorded and processed using LabSpec $^{\mathrm{TM}}$ version 5.19 .17 (Jobin-Yvon, Villeneuve d'Ascq, France).

For permanent preparation, the pieces of amber were fully embedded in a high-grade epoxy (Buehler Epoxicure, Lake Bluff, IL, USA) under vacuum (see Nascimbene \& Silverstein, 2001 for protocols). After curing, the resultant epoxy plugs surrounding each sample were cut and polished to create clear flat surfaces close to the amber and its inclusions.

Both amber fragments are currently housed in the amber collection of the Division of Invertebrate Zoology of the American Museum of Natural History, New York. All Indian amber pieces will finally be deposited in the amber collection of the INSA Project Geology at the University of Lucknow, India.

\section{Results}

\section{Description of the fossil ectomycorrhizas}

About 20 unramified, cruciform and monopodial-pinnate ectomycorrhizas are fossilized adjacent to rootlets of up to $180 \mu \mathrm{m}$ in diameter (Fig. 1a-e, Supporting Information Fig. $\mathrm{S} 1 \mathrm{a}-\mathrm{c})$. The non-mycorrhizal parts of the absorbing roots are $300 \mu \mathrm{m}$ to $8 \mathrm{~mm}$ in length and 60 to $130 \mu \mathrm{m}$ in diameter. Unbranched mycorrhizas are $320 \mu \mathrm{m}$ to $1.9 \mathrm{~mm}$ long and 90 to $140 \mu \mathrm{m}$ in diameter (Figs $1 \mathrm{~b}, \mathrm{~S} 1 \mathrm{c}$ ). Cruciform ectomycorrhizal systems (Figs 1c, $\mathrm{S} 1 \mathrm{~b}$ ) are 200 to $310 \mu \mathrm{m}$ (rarely up to $700 \mu \mathrm{m}$ ) long, and their two branches are 120 to $220 \mu \mathrm{m}$ (rarely $500 \mu \mathrm{m}$ ) long and 70 to $100 \mu \mathrm{m}$ in diameter. Monopodial-pinnate ectomycorrhizal systems (Figs 1a,d,e, S1a) mostly range between 350 and $550 \mu \mathrm{m}$ in length, and their finger-like branches are 100 to $300 \mu \mathrm{m}$ (rarely up to $530 \mu \mathrm{m}$ ) long and 60 to $90 \mu \mathrm{m}$ wide. The monopodial-pinnate system in amber fragment TAD 248b (Figs 1e, S1a) is $1.3 \mathrm{~mm}$ in length and bears five finger-like branches, in which both of the most basal branches are bifurcated.

Different developmental stages of the ectomycorrhizas are preserved in the piece of amber. Young ectomycorrhizas show dark pseudoparenchymatous mantles from which numerous irregularly septate dark pigmented hyphae of 1.2 to $3.3 \mu \mathrm{m}$ in diameter extend (Figs 1b,c,h, 2a-c, S1b,c). Their walls are 0.2 to $0.3 \mu \mathrm{m}$ thick, and iris diaphragms are possessed at the septa (Fig. $2 \mathrm{~g}$ ) whereas clamp connections are absent. 

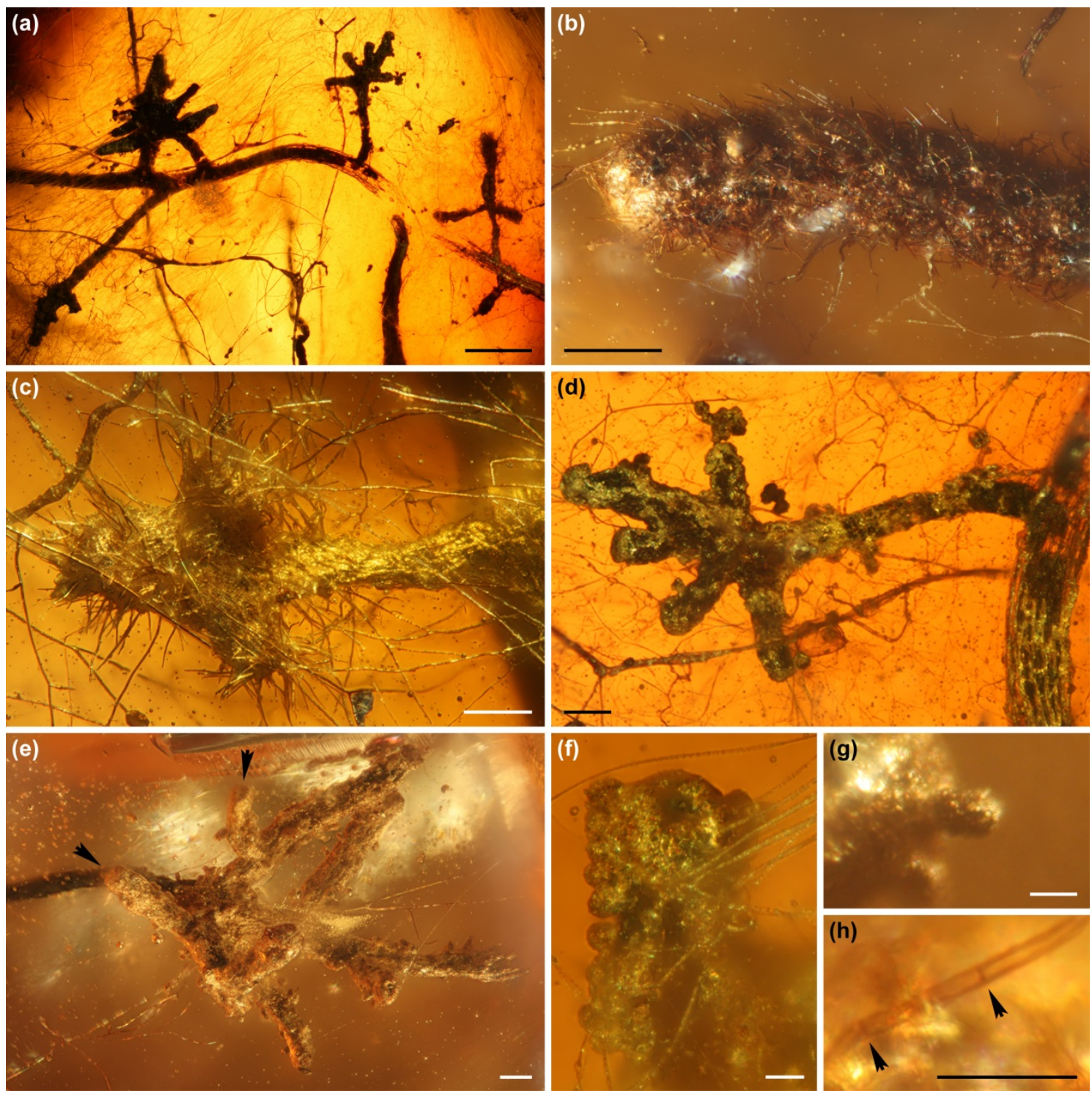

Figure 1. Light-microscopic photomicrographs of the ectomycorrhizal systems of Eomelanomyces cenococcoides gen. et spec. nov. from Eocene amber of India. (a) Overview of a rootlet with three monopodial-pinnate ectomycorrhizal systems and one cruciform system (located on the right) with surrounding mycelium (TAD 248a). The system in the middle right represents the holotype (shown in greater detail in Fig. 1(d)). (b) An unramified ectomycorrhiza which has been later removed from the amber for ultrastructural and Raman analyses (see Figs 2, 3 and Supporting Information, Fig. S2; TAD 248a). (c) Cruciform ectomycorrhizal system (TAD 248a). (d) Monopodial-pinnate ectomycorrhizal system forming microsclerotia. This system represents the holotype of E. cenococcoides gen. et spec. nov. (TAD 248a). (e) Large monopodialpinnate ectomycorrhizal system with five finger-like branches forming microsclerotia. The arrowheads show additional furcation of the basal branches (TAD 248b). (f) Microsclerotia formed at the surface of the basal branch of the system shown in the lower left of Fig. 1(a) (TAD 248a). (g) Large microsclerotium exposed at the surface of the system shown in Fig. 1(e) (TAD 248b). (h) Dark hypha with two septa (arrowheads) extending from the system shown in Fig. 1(b) (TAD 248a). Bars, $500 \mu \mathrm{m}$ (a); $100 \mu \mathrm{m}$ (b-e); $20 \mu \mathrm{m}$ (f-h). 

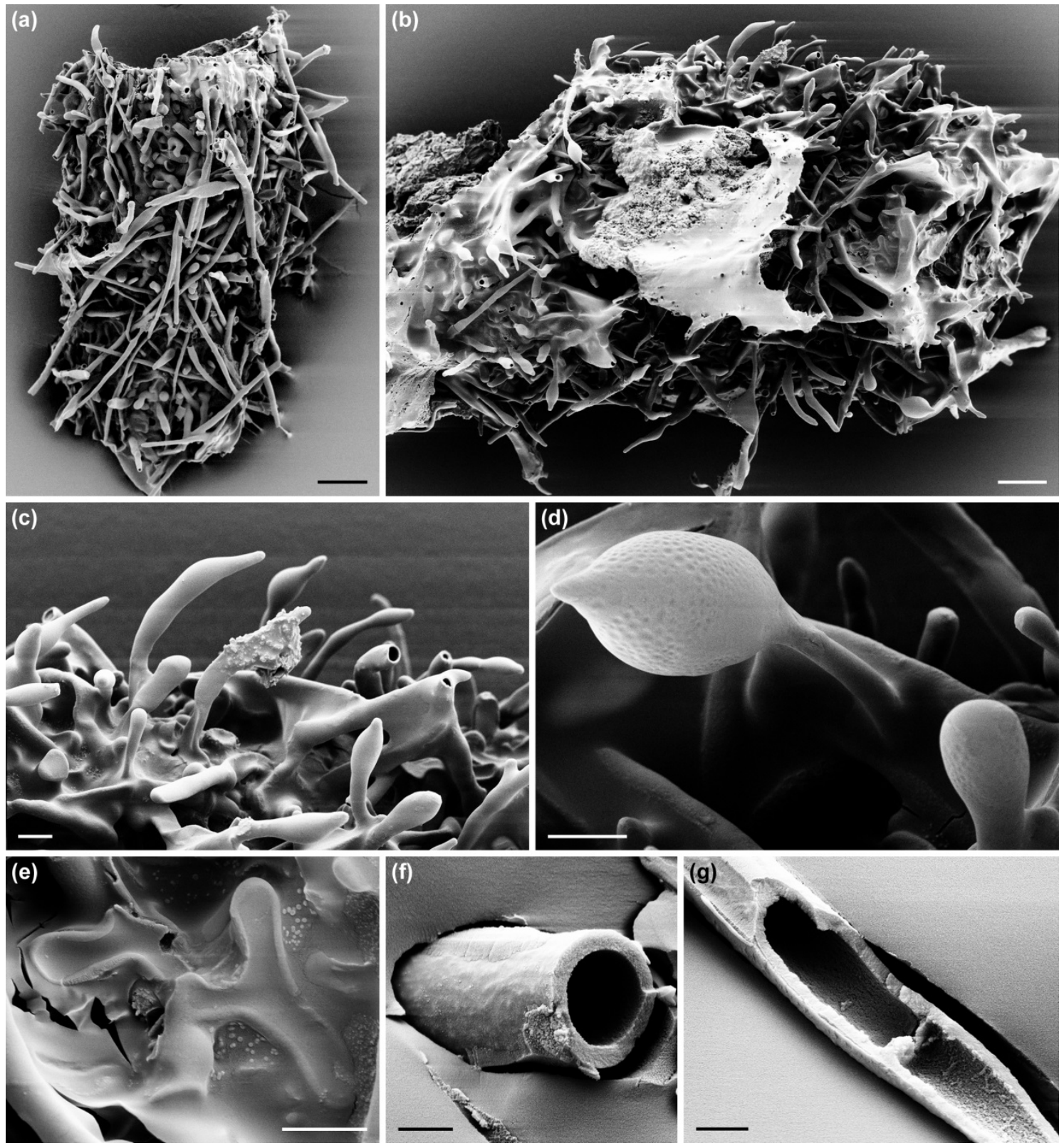

Figure 2. Scanning electron micrographs of Eomelanomyces cenococcoides gen. et spec. nov. from Eocene amber of India (TAD 248a). (a,b) Fragments of the pseudoparenchymatous mantle of the ectomycorrhiza shown in Fig. 1(b). (c) Surface of the pseudoparenchymatous mantle showing extending hyphae with initial formation of chlamydospore-like inflated distal hyphal ends. (d) Lemon-shaped inflated distal hyphal end of a short hypha extending from the mantle. (e) Surface of the pseudoparenchymatous mantle with short forked flat hyphae. (f) Hypha showing thick walls at crossbreak. (g) Broken hypha exposing a septum with an iris diaphragm. Bars, $20 \mu \mathrm{m}(\mathrm{a}, \mathrm{b}) ; 5 \mu \mathrm{m}$ (c-e); $1 \mu \mathrm{m}$ $(f, g)$.

Compounds of melanins were detectable in these dark hyphae using Raman spectroscopy. Some of the peaks were assignable to the key monomers of eumelanin: hydroquinone, indolequinone and semiquinone (Fig. 4). Some of these hyphae form chlamydospore-like inflated distal hyphal ends which are clavate or broad fusiform to lemon-shaped and 12 to $16 \mu \mathrm{m}$ long and 6.5 to $9.7 \mu \mathrm{m}$ wide (Figs 2c,d, S2d). Short 
forked flat hyphae of 7 to $15 \mu \mathrm{m}$ length and 2.4 to $5 \mu \mathrm{m}$ width and about $0.5 \mu \mathrm{m}$ thickness (Figs 2e, S2a), as well as short young hyphae of 2.5 to $3 \mu \mathrm{m}$ diameter (Fig. $\mathrm{S} 2 \mathrm{a}$ ), are sometimes visible at the surface of the pseudoparenchymatous mantle. Dense hyphal systems extend in all directions into the clear translucent amber (Figs 1a,c, S1b,c), suggesting that some ectomycorrhizas were still alive when initially embedded. Sometimes several hyphae form simple rhizomorphs that are mostly about $10 \mu \mathrm{m}$ in diameter or thinner, seldom reaching $75 \mu \mathrm{m}$ (Figs 3a,b, S2b). Generally, hyphae exhibit thick cell walls (Figs 2f,g, S2e) and are frequently coated by a toluene-insoluble substance (Fig. S2b,c). Single hyphae within the rhizomorphs are $1-3 \mu \mathrm{m}$ wide. The dark hyphae of the mycelium are often coated by light circular structures possessing a rough surface (Fig. S1d). Hyphae are absent around older ectomycorrhizal systems; instead, numerous spherical to ovoid microsclerotia (hardened mycelia serving as dormant stages) are formed at their surface (Figs $1 \mathrm{~d}-\mathrm{g}, \mathrm{S} 1 \mathrm{~g}$ ). The microsclerotia are mostly 35 to $40 \mu \mathrm{m}$ long and 25 to $30 \mu \mathrm{m}$ wide, sometimes reaching 55 to $60 \mu \mathrm{m}$ in length and $50 \mu \mathrm{m}$ in width. Small ones are only 15 to $20 \mu \mathrm{m}$ in size. Microsclerotia are also formed in the nearby hyphal systems (Figs 3d, S1f). Clavate short hyphal ends of $15 \mu \mathrm{m}$ to $43 \mu \mathrm{m}$ in length and $5.5 \mu \mathrm{m}$ to $6.5 \mu \mathrm{m}$ in width are regularly formed in the mycelium (Figs 3c, S1d,e). Sometimes they appear at regular distances of about 450 to $550 \mu \mathrm{m}$ apart at the supporting hyphae. The otherwise thick walls of the hyphae become thinner and almost disappear in these branches (Figs 3c, S1e).

Preservation of the ectomycorrhizas is excellent, allowing description of the mycobiont as Eomelanomyces cenococcoides gen. et spec. nov. (see below). E. cenococcoides is a fungus containing melanin and developing ectomycorrhizas as black pseudoparenchymatous mantles on the surface of absorbing roots of the host. Hyphae with iris diaphragms at the septa extend outward from this mantle. In this regard, the fossil is similar to the recent anamorphic genus Cenococcum, but distinguished by the high variability in the branching of the ectomycorrhizal systems and by the regular formation of microsclerotia.

\section{Taxonomic summary}

Eomelanomyces cenococcoides Beimforde, Dörfelt et A. R. Schmidt gen. et spec. nov. (Figs 1-3, Supporting Information Figs S1,S2)

Descriptio: Fungus anamorphus cum substantia 'melanin' et ectomycorrhizam formans in plantis. Systema mycorrhizae non ramosa vel cruciformis aut monopodialiter pinnata. Rami frequenter situ in dextero angulo. Tunica mycorrhizae in superficie est pseudoparenchymatica cum cellulis planis, $60-140 \mu \mathrm{m}$ in diametro, frequenter cum 
hyphis ramosis, coloratis, non regularibus septis, $1.2-3.3 \mu \mathrm{m}$ in diametro. Ex tunica pseudoparenchymaticae hyphae eminentes cum septis. Septa cum simplicibus centralibus cavis ut in genere recentem Cenococcum. Nonnullae hyphae apices formantes ad similitudinem chlamydosporibus, usque ad $8 \times 5 \mu \mathrm{m}$ in diametro. Hyphae conjunctae in chordam myceliae ut in simplicibus rhizomorphis. In aetate mycorrhizae sine vividis ramosis hyphis eminentibus autem cum multis microsclerotiis ovoideis, ca. $35-50 \times 25-35 \mu \mathrm{m}$ in diametro.

Typus: In resina fossile ex India, collectio numerus AMNH TAD 248; Systema ectomycorrhizae est spectata in figura $1 \mathrm{~d}$ est holotypus.

Etymologia: Eo, eos: Eocaen; melanos: nigrum. Epitheton speciei propter similitudinem cum recenti genere anamorpho Cenococcum.

\section{Discussion}

\section{Assignment of the Mycobiont}

Although the fungal mantle is excellently preserved, the root tissue of the host plant decayed in the amber (likely due to taphonomic conditions affecting the preservation of woody tissues). Consequently, we could not document the Hartig net in which the mycobiont penetrates the intercellular spaces of the host.

We assign the ectomycorrhizas of amber piece no. TAD 248 to a single fossil species because all (including different developmental stages) are arranged close to each other on the rootlets. Some photomicrographs of Fig. 1 and Supporting Information Fig. S1 may suggest variation in color of the ectomycorrhizas and adjacent hyphae because different intensities of transmitted and incident light were used. Lighter color is also caused by a refractive nanometre-sized space that sometimes appears between the amber inclusion and the surrounding resin. This gas-filled space probably originated by shrinkage of solidifying resin and desiccation of the inclusion during fossilization.

We consider Eomelanomyces cenococcoides to belong to the Dothidiomycetes (Ascomycota) because of (1) its dark melanised hyphae, (2) the formation of a mycorrhizal mantle, (3) the regular formation of microsclerotia, and (4) the similarity of this fossil to the extant anamorphic genus Cenococcum.

The septal porus is an iris diaphragm, which is not swollen like the dolipore of the Agaricomycotina (see Fig. 2g). Furthermore, clamp connections are absent. The dark colour of the pseudoparenchymatous mantle's surface and of the hyphae is similar to the extant anamorphic genus Cenococcum, whose teleomorph is a species of the 
Dothideomycetes. The only extant species of this genus, Cenococcum geophilum Fr., forms mostly unbranched mycorrhizas with modern hosts of the Spermatophyta.

A particular feature of the mycelium surrounding the ectomycorrhizal systems is the regular occurrence of clavate short hyphal ends with very thin walls (Figs 3c, S1d,e). It remains unclear if these structures were for nutrient uptake.
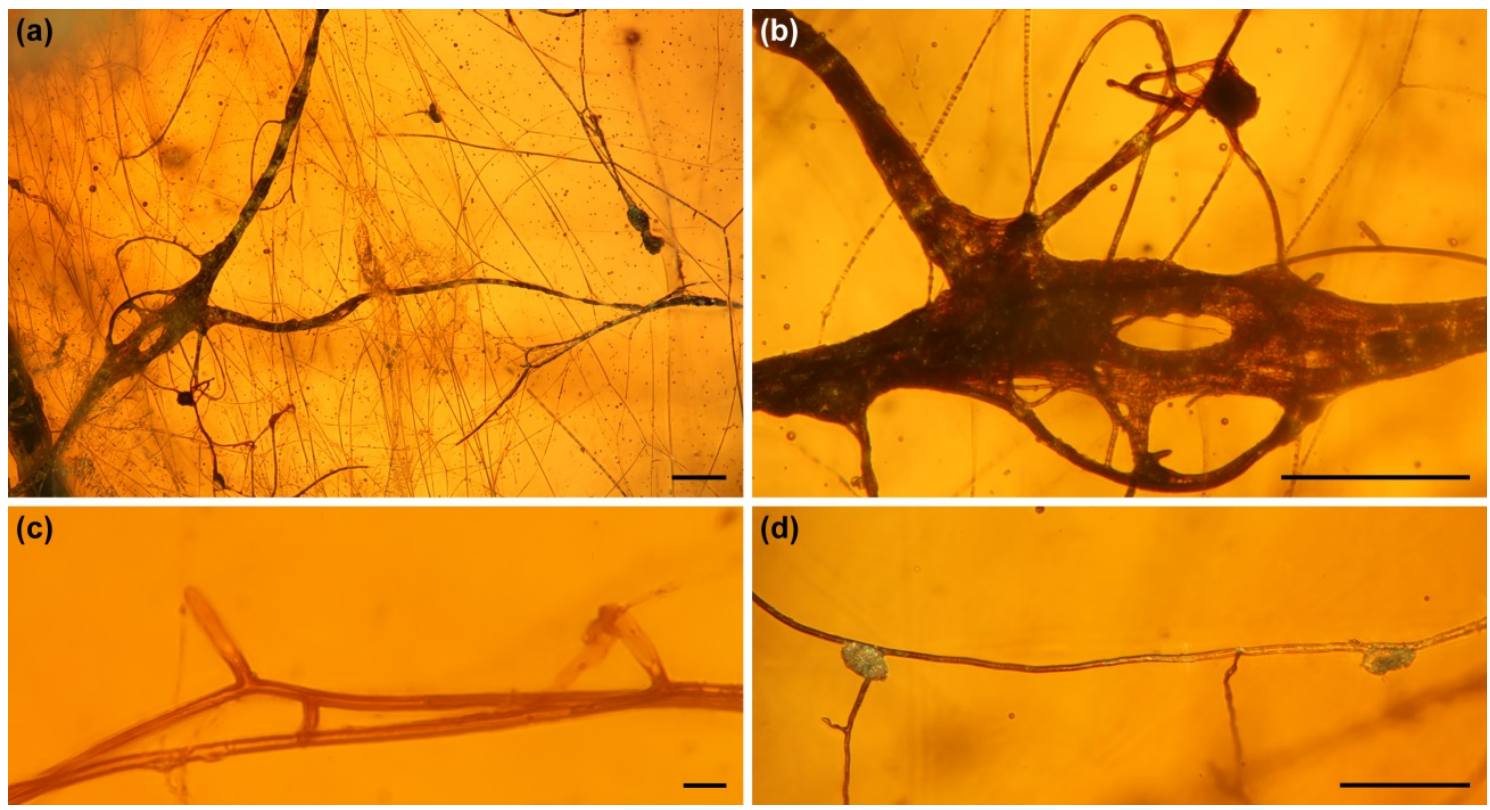

Figure 3. Light-microscopic photomicrographs of the mycelium of Eomelanomyces cenococcoides gen. et spec. nov. surrounding rootlets and ectomycorrhizal systems from Eocene amber of India (TAD 248a). (a) Branched rhizomorphs. (b) Detail of Fig. 4 (a). Numerous hyphae composing the rhizomorph are visible. (c) Two hyphae each forming a clavate short hyphal end. The walls of the hyphae thin and almost disappear in these branches. (d) Two microsclerotia formed at a branched hypha. Bars, $100 \mu \mathrm{m}(\mathrm{a}, \mathrm{b}, \mathrm{d})$; $10 \mu \mathrm{m}(\mathrm{c})$.

\section{Search for fossil melanin in Eomelanomyces cenococcoides}

Raman studies of melanin from modern samples are reported by several research groups for different melanin-containing substances (e.g. Samokhvalov et al., 2004), as well as density-functional calculations of the three melanin monomers (Powell et al., 2004).

The Raman spectrum of the dark hyphae of Eomelanomyces cenococcoides revealed two very broad bands which are centered at 1354 and $1576 \mathrm{~cm}^{-1}$ (Fig. 4). This spectrum has a great similarity to the typical spectrum of amorphous carbon, with peaks at 1350 and $1550 \mathrm{~cm}^{-1}$ (Robertson, 1986). These two peaks are caused by vibrations of carbon atoms arranged in a graphitic-like structure. However, due to the molecular structure of melanin, other vibrational modes involving oxygen, hydrogen and nitrogen should be visible. When analysing the spectrum with a Gauss Lorentz function, several underlying peaks could be identified between 1000 and $1600 \mathrm{~cm}^{-1}$. Based on the work of Powell et 
al. (2004), we were able to assign several of these peaks to hydroquinone, indolequinone and semiquinone, the key monomers of eumelanin. In the calculated spectrum of Powell et al. (2004) the peaks are very narrow, whereas our spectra, as well as those of Capozzi et al. (2005), show broad bands. This may be caused by the high fluorescence background, and by the degradation of the melanin molecules due to the Eocene age of our sample. Although eumelanins are not identical to fungal melanins (Butler \& Day, 1998), the vibrational modes detectable with Raman spectroscopy likely do not show essential differences (see Cappitelli et al., 2005).

Previous studies exclusively report fossil melanins or melanosomes from animals, e.g. melanin from Triassic ammonites (Mathur, 1996), and fossil melanosomes from Jurassic to Eocene feathers (Vinther et al., 2008; Li et al., 2010). Thus, our Raman spectrum provides the first indication of fossil fungal melanins in amber, and in fact the first record of melanin in a fossil fungus.

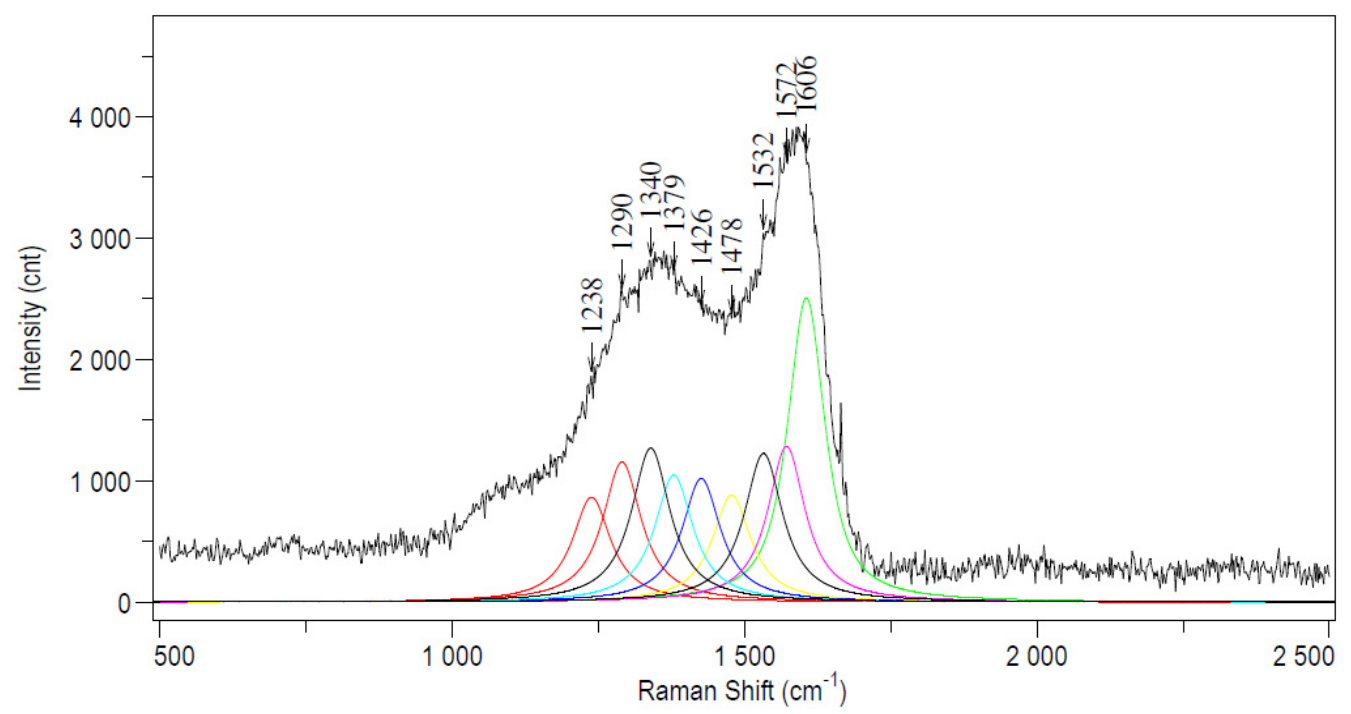

Figure 4. Raman spectrum of a single hypha of the ectomycorrhiza shown in Fig. 1(b). The coloured pattern underneath the spectrum represents the peaks analysed by Gauss- Lorentz function. The peak at $1426 \mathrm{~cm}^{-1}$ can be assigned to hydroquinone, those at 1340,1532 and $1572 \mathrm{~cm}^{-1}$ to indolequinone, and the one at $1290 \mathrm{~cm}^{-1}$ to semiquinone. The main peak at $1606 \mathrm{~cm}^{-1}$ represents carbon bonding.

\section{Probable assignment of the host tree}

The ectomycorrhizas reported here were fossilized in a single piece of clear translucent amber. The only syninclusions of the fossil ectomycorrhizas are several lepidopteran scales. We assume that the resin originally filled a small hole inside the litter or soil horizon of the forest floor that contained vital ectomycorrhizas. The resin may have been released by the roots or dropped from above by one of the trees.

Today, arbuscular endomycorrhizas typically predominate in tropical forests (Janos, 
1983; McGuire, 2007). However, several ecologically important tropical plant families, notably the amber-producing Dipterocarpaceae, are ectomycorrhizal (Lee, 1998). If present, ectomycorrhizal angiosperm trees generally make up a large portion of the total forest area, and can sometimes even dominate tropical rainforests (Connell \& Lowman, 1989; McGuire, 2007), as dipterocarps do today in parts of Southeast Asia. The chemical analysis of the amber from the Tadkeshwar Mine revealed a class II or dammar-type resin (Dutta et al., 2009; 2011; Mallick et al., 2009; Rust el al., 2010), a cadinene-based polymer, which is produced primarily by trees in the Dipterocarpaceae (Van Aarssen et al., 1994; Anderson \& Muntean, 2000). Independent evidence for the presence of Lower Eocene Dipterocarpaceae was recently obtained from fossil pollen grains that were found in the same sediments (Dutta et al., 2011). In addition, fossil wood samples attached to amber pieces showed microanatomical affinity to Dipterocarpaceae, including amber-filled resin canals, further substantiating the botanical source of this amber (Nascimbene et al., 2010; Rust et al., 2010).

The Gujarat region of India during the Lower Eocene was characterized by a strong occurrence of evergreen angiosperms (e g. Sahni \& Kumar, 1974; Willis \& McElwain, 2001). Gymnosperms occurred rarely, and only a few fossils from the families Araucariaceae, Podocarpaceae and Ginkgoaceae have ever been recovered (Salujha et al., 1967) - their extant representatives are all characterized by arbuscular mycorrhizas, like most other gymnosperms. Based on direct fossil evidence, the Cambay amber and associated sediments provide one of the earliest unequivocal Asian records of a diverse, broadleaf tropical angiosperm forest (Rust et al., 2010).

We consider the host of Eomelanomyces cenococcoides to be an angiosperm, because representatives of the family Pinaceae and the genus Gnetum, the only known extant gymnosperms forming ectomycorrhizas (e.g., Brundrett, 2002), have not been observed in the Eocene of India. Furthermore, besides dipterocarps, no other angiosperms with known ectomycorrhizal associations, past or present, have been identified from this deposit. We therefore propose that the amber-producing Dipterocarp is the probable host of Eomelanomyces cenococcoides.

\section{Palaeobiogeographical implications}

The palaeogeographic and temporal origin of Dipterocarpaceae and their association with ectomycorrhizal fungi have frequently been discussed. It is typically suggested that dipterocarps originated in eastern Africa or Madagascar and drifted northward on the Indian platform, reached Asia during the Eocene and spread (e. g. Dutta et al., 2011). Alternatively, an origin in Southeast Asia has been proposed and taken into account (Lakhanpal, 1970; Sasaki, 2006). However, the monophyly of the three subfamilies of 
Dipterocarpaceae and of the Sarcolaenaceae, along with their consistent association with ectomycorrhizal fungi, suggest that the potential to form ectomycorrhizas is an ancestral character of the Dipterocarpaceae family (Ducousso et al. 2004; Moyersoen, 2006). Ectomycorrhizal symbioses may have conferred a selective advantage for some tropical tree species (e. g. McGuire, 2007), even in early tropical broadleaf rainforests, and the high diversity and abundance of Dipterocarpaceae in Asia might be based on their potential to associate with ectomycorrhizal fungi.

Ectomycorrhizal associations are considered to be unstable evolutionarily dynamic associations that evolved independently in several major clades of fungi (Hibbett \& Matheny, 2009) as well as several times within the angiosperm clade that includes Rosids and Asterids and within the Pinaceae (Fitter \& Moyersoen, 1996; Hibbett \& Matheny, 2009). Consequently, Eomelanomyces cenococcoides itself is not necessarily an ancestral mycobiont of its host. The only previously reported fossil record of ectomycorrhizas is actually from the roots of Eocene (ca 50 million years old) Pinaceae from Vancouver Island (LePage, 1997). Our find provides evidence that angiospermous ectomycorrhizal associations in the Paleogene tropics occurred contemporaneously with gymnospermous ectomycorrhizal associations in the Nearctic.

\section{Acknowledgements}

The authors would like to thank David A. Grimaldi (New York), Matthias Gube (Jena), Heike Heklau (Halle), Jouko Rikkinen (Helsinki), Kerstin Schmidt (Jena) and Gerhard Wagenitz (Göttingen) for their helpful comments, Jes Rust (Bonn) for advice, as well as Wolfgang Dröse (Göttingen) and Dorothea Hause-Reitner (Göttingen) for assistance with histology and the field emission microscope. We are grateful to the anonymous reviewers for their constructive suggestions. H.S. and R.S.R. thank Ashok Sahni (Lucknow) for his unfailing encouragement and kind advice. H.S. would like to recognize Naresh Chandra Mehrotra, the director of the Birbal Sahni Institute of Palaeobotany (Lucknow), for his support of laboratory and field work. R.S.R. thanks the Department of Science and Technology, Government of India. This is publication number 65 from the Courant Research Centre Geobiology, funded by the German Initiative of Excellence. 


\section{References}

Alexander IJ. 2006. Ectomycorrhizas - out of Africa? New Phytologist 172: 589-591.

Anderson KB, Muntean JV. 2000. The nature and fate of natural resins in the geosphere. Part X. Structural characteristics of the macromolecular constituents of modern Dammar resin and Class II ambers. Geochemical Transactions 7: 2.

Brundrett MC. 2002. Coevolution of roots and mycorrhizas of land plants. New Phytologist 154: 275-304.

Brundrett M. 2009. Mycorrhizal associations and other means of nutrition of vascular plants: understanding the global diversity of host plants by resolving conflicting information and developing reliable means of diagnosis. Plant Soil 320: 37-77.

Butler MJ, Day AW. 1998. Fungal melanins: a review. Canadian Journal of Microbiology 44: 1115-1136.

Cairney JWG. 2000. Evolution of mycorrhiza systems. Naturwissenschaften 87: $467-475$.

Capozzi V, Perna G, Gallone A, Biagi PF, Carmone P, Fratello A, Guida G, Zanna P, Cicero R. 2005. Raman optical spectroscopy of eumelanin films. Journal of Molecular Structure 744-747: 717-721.

Cappitelli F, Vicini S, Piaggio P, Abbruscato P, Princi E, Casadevall A, Nosanchuk JD, Zanardini E. 2005. Investigations of fungal deterioration of synthetic paint binders using vibrational spectroscopic techniques. Macromolecular Bioscience 5: 49-57.

Connell JH, Lowman MD. 1989. Low-diversity tropical rain forests: some possible mechanisms for their existence. American Naturalist 134: 88-119.

Ducousso M, Béna G, Bourgeois C, Buyck B, Eyssartier G, Vincelette M, Rabevohitra R, Randrihasipara L, Dreyfus B, Prin Y. 2004. The last common ancestor of Sarcolaenaceae and Asian dipterocarp trees was ectomycorrhizal before the India Madagascar separation, about 88 million years ago. Molecular Ecology 13: 231236.

Dutta S, Mallick M, Bertram N, Greenwood PF, Matthews RP. 2009. Terpenoid composition and class of Tertiary resins from India. International Journal of Coal Geology 80: 44-55.

Dutta S, Tripathi SM, Mallick M, Mathews RP, Greenwood PF, Rao MR, Summons RS. 2011. Eocene out-of-India dispersal of Asian dipterocarps. Review of Palaeobotany and Palynology 166: 63-68.

Fitter AH, Moyersoen B. 1996. Evolutionary Trends in root microbe symbiosis. Philosophical Transactions of the Royal Society B 351: 1367-1375.

Hibbett DS, Matheny PB. 2009. The relative ages of ectomycorrhizal mushrooms and their plant hosts estimated using Bayesian relaxed molecular clock analyses. BMC Biology 7: 13. 
Janos DP. 1983. Tropical mycorrhizas, nutrient cycles and plant growth. In: Sutton SL, Whitmore TC, Chadwick AC, eds. Tropical rain forest: ecology and management. Oxford, UK: Blackwell Scientific Publications, 327-345.

Lakhanpal RN. 1970. Tertiary floras of India and their bearing on the historical geology of the region. Taxon 19: 675-694.

Lee SS. 1998. Root Symbiosis and Nutrition. In: Appanah S, Turnbull JM, eds. $A$ Review of Dipterocarps Taxonomy, ecology and silviculture. Bogor, Indonesia: Center for International Forestry Research, 99-114.

LePage A, Currah RS, Stockey RA, Rothwell GW. 1997. Fossil ectomycorrrhizae from the middle Eocene. American Journal of Botany 84: 410-412.

Li Q, Gao K-Q, Vinther J, Shawkey MD, Clarke JA, D’Alba L, Meng Q, Briggs, DEG, Prum RO. 2010. Plumage Color Patterns of an Extinct Dinosaur. Science 327: 13691372.

Mallick M, Dutta S, Greenwood PF, Bertram N. 2009. Pyrolytic and spectroscopic studies of Eocene resin from Vastan Lignite Mine, Cambay Basin, western India. Journal of the Geological Society of India 74: 16-22.

Malloch DW, Pirozynski KA, Raven PH. 1980. Ecological and evolutionary significance of mycorrhizal symbioses in vascular plants (a review). Proceedings of the National Academy of Sciences of the United States of America 77: 2113-2118.

Mathur A. 1996. Über Ammoniten der Kössener Schichten und den Nachweis der Tintenbeutel-Substanz Melanin bei ihnen. Documenta Naturae 102: 1-161.

McGuire KL. 2007. Common ectomycorrhizal networks may maintain monodominance in a tropical rain forest. Ecology 88: 567-574.

Moyersoen B. 2006. Pakaraimaea dipterocarpacea is ectomycorrhizal, indicating an ancient Gondwanaland origin for the ectomycorrhizal habit in Dipterocarpaceae. New Phytologist 172: 753-762.

Nascimbene PC, Silverstein H. 2001. The preparation of fragile Cretaceous ambers for conservation and study of organismal inclusions. In: Grimaldi D, ed. Studies on Fossils in Amber, with Particular Reference to the Cretaceous of New Jersey. Leiden, The Netherlands: Backhuys Publishers, 93-102.

Nascimbene PC, Grimaldi DA, Anderson, KB, Schmidt AR, Rust J, Williams CJ. 2010. Physicochemical comparisons and implications of new amber deposits from the Lower Eocene of India and the mid Cretaceous of Ethiopia. FossilsX3: Insects, Arthropods, Amber, Capital Normal University, Beijing, China, August 20-25, 2010, Abstracts, 155.

Powell BJ, Baruah T, Bernstein N, Brake K, McKenzie RH, Meredith P, Pederson MR. 2004. A first-principles density-functional calculation of the electronic and vibrational structure of the key melanin monomers. Journal of Chemical Physics 120: 8608-8615. 
Remy W, Taylor TN, Hass H, Kerp H. 1994. Four hundred-million-year old vesicular arbuscular mycorrhizae. Proceedings of the National Academy of Sciences of the United States of America 91: 11841-11843.

Robertson J. 1986. Amorphous carbon. Advances in Physics 35: 317-374.

Rust J, Singh H, Rana RS, McCann T, Singh L, Anderson K, Sarkar N, Nascimbene PC, Stebner F, Thomas JC et al. 2010. Biogeographic and evolutionary implications of a diverse paleobiota in amber from the early Eocene of India. Proceedings of the National Academy of Sciences of the United States of America 107: 18360-18360.

Sahni A, Kumar V. 1974. Paleogene Paleobiogeography of the Indian Subcontinent. Palaeogeography, Palaeoclimatology, Palaeoecology 15: 209-226.

Salujha, SK, Srivastava NC, Rawat MS. 1967. Microfloral assemblage from Subathu sediments of Simla Hills. Journal of the Palaeontological Society of India 12: 2540.

Samokhvalov A, Liu Y, Simon JD. 2004. Charcterization of the Fe(III)-binding site in Sepia eumelanin by resonance Raman confocal microspectroscopy. Photochemistry and Photobiology 80: 84-88.

Sasaki S. 2006. Ecology and Physiology of Dipterocarpaceae. In: Suzuki K, Ishii K,

Sakurai S, Sasaki S, eds. Plantation Technology in Tropical Forest Science. Tokyo, Japan: Springer, 3-22.

Van Aarssen BGK, De Leeuw JW, Collinson M, Boon JJ, Goth K. 1994. Occurrence of polycadinene in fossil and recent resins. Geochimica et Cosmochimica Acta 58: 223-229.

Vinther J, Briggs DEG, Prum RO, Saranathan V. 2008. The colour of fossil Feathers. Biology Letters 4: 522-525.

Wang B, Yeun LH, Xue J-Y, Liu Y, Ané J-M, Qiu Y-L. 2010. Presence of three mycorrhizal genes in the common ancestor of land plants suggests a key role of mycorrhizas in the colonization of land by plants. New Phytologist 186: 514-525.

Willis KJ, McElwain JC. 2001. Evolution of Plants. Oxford, UK: Oxford University Press. 


\section{Supporting Information: Figs S1 and S2 for}
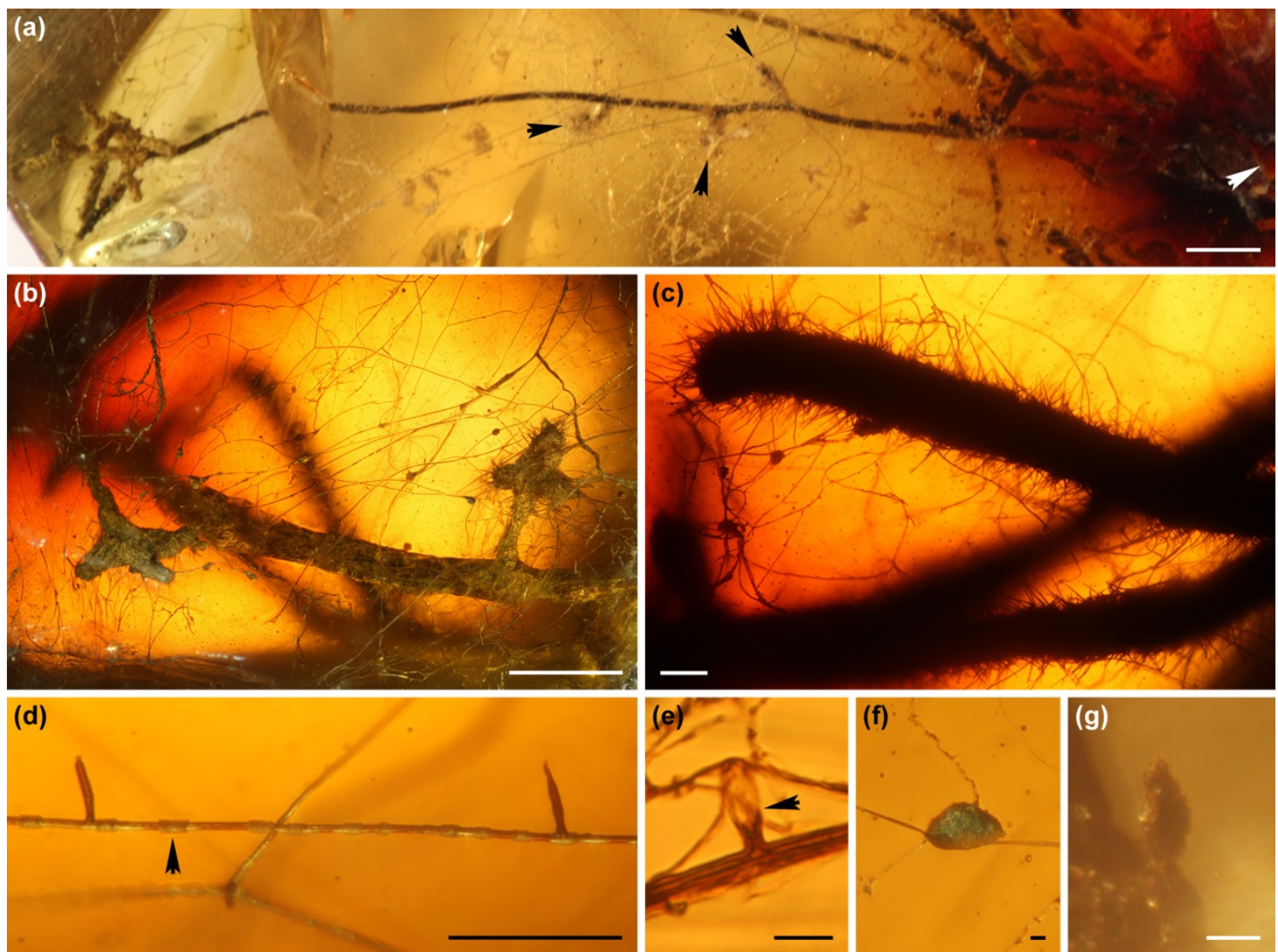

Figure S1. Additional light-microscopical photomicrographs of Eomelanomyces cenococcoides gen. et spec. nov. from Eocene amber of India. (a) Long absorbing root with three unbranched ectomycorrhizas (black arrowheads) and one monopodial-pinnate system forming microsclerotia (left), which is shown magnified in Fig. 1e. The white arrowhead indicates the location of the main root (TAD 248b). (b) Overview of a rootlet with two cruciform ectomycorrhizal systems. The right system is shown enlarged in Fig. 1c; the left system possesses microsclerotia. The long unramified ectomycorrhiza out of focus in the middle of the background is shown enlarged in Fig. S1c (TAD 248a). (c) Long unramifiedectomycorrhiza (TAD 248a). (d) Hypha with two clavate short hyphal ends. The dark supporting hypha is coated by light circular structures possessing a rough surface (arrowhead). (e) One clavate short hyphal end with immediately thinning cell wall (arrowhead). (f) Microsclerotium at a hypha. (g) Large microsclerotium exposed at the surface of the system shown in Figs 1e and S1a (TAD 248b). Scale bars: (a,b) $500 \mu \mathrm{m},(\mathrm{c}, \mathrm{d}) 100 \mu \mathrm{m},(\mathrm{e}-\mathrm{g}) 10 \mu \mathrm{m}$. 

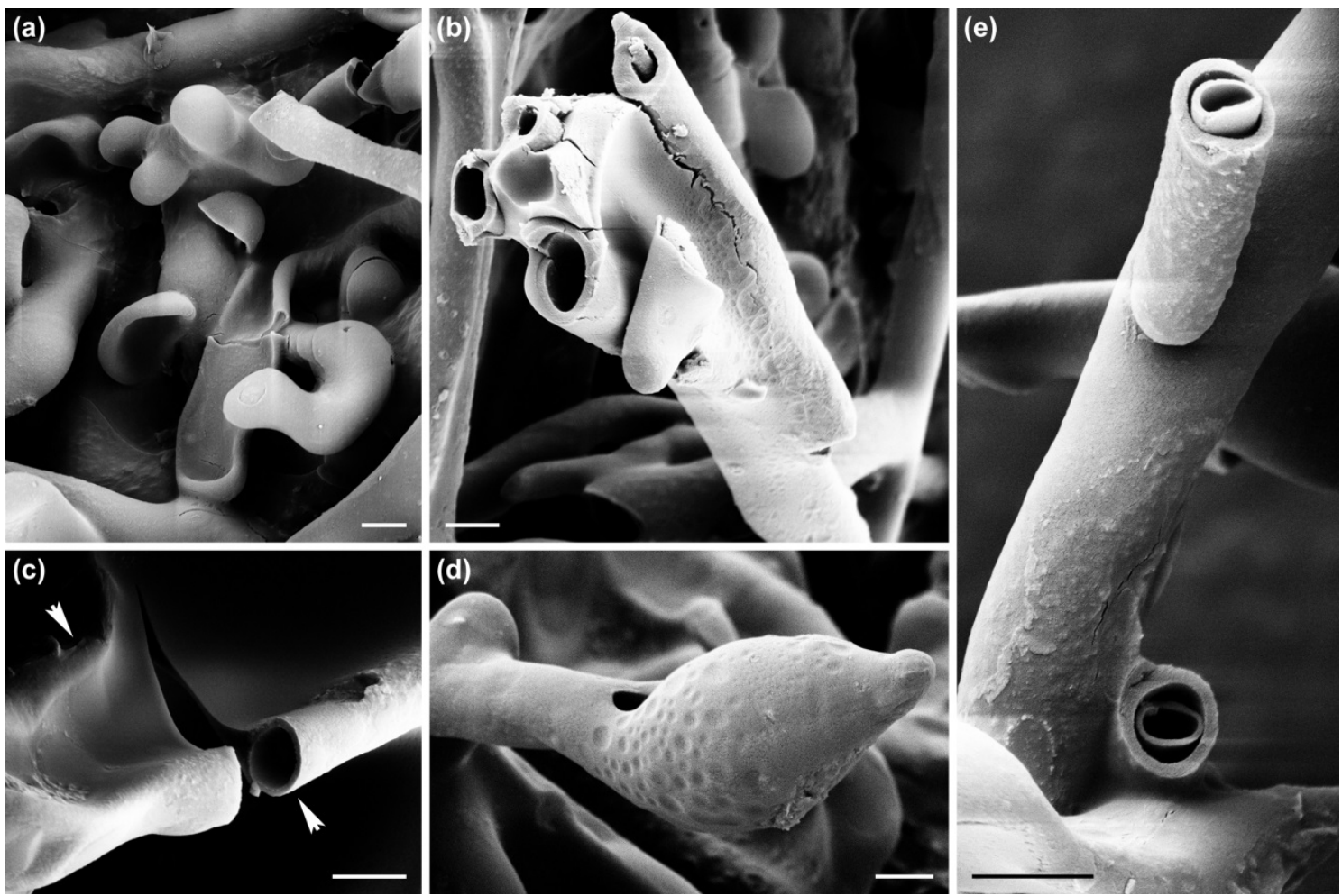

Figure S2. Additional scanning electron micrographs of Eomelanomyces cenococcoides gen. et spec. nov. from Eocene amber of India (TAD 248a). (a) A flat hypha and budding young hyphae at the surface of the pseudoparenchymatous mantle. (b) Four hyphae connected by a toluene-insoluble substance to form a simple rhizomorph extending from the ectomycorrhiza. (c) Two hyphae (arrowheads) connected by a toluene-insoluble substance. (d) Fusiform inflated distal hyphal ends of short hyphae extending from the mantle. (e) Hyphae showing two layers of the outer walls at cross-break. Scale bars: $2 \mu \mathrm{m}$. 
Appendix 6

\section{Appendix 6}

Beimforde C, Feldberg K, Nylinder S, Rikkinen J, Tuovila H, Dörfelt H, Gube M, Jackson D, Reitner J, Seyfullah LJ, Schmidt AR (submitted). Estimating the Phanerozoic history of the Ascomycota lineages: combining fossil and molecular data. Molecular Phylogenetics and Evolution.

Impact factor of Molecular Phylogenetics and Evolution 2011: 3.982, according to Journal Citation Reports 


\section{Estimating the Phanerozoic history of the Ascomycota lineages: combining fossil and molecular data}

Christina Beimforde ${ }^{\mathrm{a}}$, Kathrin Feldberg ${ }^{\mathrm{b}}$, Stephan Nylinder ${ }^{\mathrm{c}}$, Jouko Rikkinen ${ }^{\mathrm{d}}$, Hanna Tuovila $^{\mathrm{d}}$, Heinrich Dörfelt ${ }^{\mathrm{e}}$, Matthias Gube ${ }^{\mathrm{e}}$, Daniel Jackson ${ }^{\mathrm{a}}$, Joachim Reitner ${ }^{\mathrm{a}}$, Leyla J. Seyfullah ${ }^{\mathrm{a}} \&$ Alexander R. Schmidt ${ }^{\mathrm{a}}$

${ }^{a}$ Courant Research Centre Geobiology, Georg-August-Universität Göttingen, 37077 Göttingen, Germany.

${ }^{\mathrm{b}}$ LMU Department für Biologie Systematische Botanik und Mykologie, 80638 München, Germany ${ }^{\mathrm{c}}$ Department of Botany, Swedish Museum of Natural History, P. O. Box 50007, SE-104 05 Stockholm, Sweden. ${ }^{\mathrm{d}}$ Department of Biosciences, PO Box 65, University of Helsinki, FIN-00014 Helsinki, Finland. ${ }^{\mathrm{e}}$ Mikrobielle Phytopathologie and Institut für Ökologie, Friedrich-Schiller-Universität Jena, 07743 Jena, Germany.

* Author for correspondence: Christina Beimforde (christina.beimforde@geo.uni-goettingen.de) 


\begin{abstract}
The phylum Ascomycota is by far the largest group in the fungal kingdom. Ecologically important mutualistic associations such as mycorrhizae and lichens have evolved in this group, which are regarded as key innovations that supported the evolution of land plants. Only a few attempts have been made to date the origin of Ascomycota lineages by using molecular clock methods. This is primarily due to the lack of satisfactory fossil calibration data for the Ascomycota. For this reason we have evaluated all of the oldest available ascomycete fossils from amber (Albian to Miocene) and chert (Devonian and Maastrichtian). The fossils represent four major ascomycete lineages (Lecanoromycetes, Laboulbeniomycetes, Dothideomycetes, and Eurotiomycetes). We have assembled a multi-gene data set (18SrDNA, 28SrDNA, RPB1 and RPB2) from a total of 145 taxa representing all main groups of the Ascomycota and utilized fossil ascomycetes to estimate divergence times of Ascomycota lineages with a Bayesian approach. This is the first study to combine molecular data with multiple fossil calibration points solely from within the Ascomycota. Our results suggest an initial diversification of ascomycetes in the Cambrian, followed by repeated splits of lineages throughout the Phanerozoic, and indicate that this continuous diversification was unaffected by mass extinctions. We suggest that the ecological diversity within each lineage ensured that at least some taxa of each group were able to survive global crises such as mass extinctions and rapidly recovered.
\end{abstract}

Keywords: Amber, Ascomycota, BEAST, divergence times estimates, fossil constraints, fungi 


\section{Introduction}

The fungi constitute a major group of eukaryotic organisms (Hawksworth, 1991, 2001). They exhibit a broad variety of lifestyles and morphologies ranging from single celled organisms to multi-cellular colonies which can be among the largest and possibly oldest organisms on earth (Brazee et al., 2012). Most aquatic and terrestrial ecosystems are occupied by a diverse range of fungal species. With over 64,000 described species in approximately 6,400 genera, the phylum Ascomycota is by far the largest phylum in the fungal kingdom (Kirk et al., 2008; Blackwell, 2011). The autapomorphy of this group is a sack-like structure, the ascus, in which the sexual spores are produced. Species of the Ascomycota are extremely variable in morphology and ecology, and play important roles in many ecosystems. As degraders of persistent organic materials such as lignin and keratin, ascomycetes play an important role in nutrient cycling. Additionally, many ascomycetes participate in symbiotic associations including mycorrhizae and lichens.

Phylogenetic relationships among major groups of the Pezizomycotina have been the subject of many recent studies (e.g. Spatafora et al., 2006; Schoch et al., 2009, Miadlikowska et al., 2006; Hibbett et al., 2007; Eversberger et al., 2012; Kumar et al., 2012, Morgenstern et al., 2012). Several attempts have also been made to date the origin and subsequent evolution of main fungal lineages by molecular clock methods (e. g. Heckman et al., 2001; Sanderson, 2003a; Berbee and Taylor, 1993, 2007; Taylor and Berbee, 2006, Padovan et al., 2005, Lücking et al., 2009, Taylor and Berbee, 2010; Gueidan et al., 2011, Floudas et al., 2012, Ohm et al., 2012). Fungi derived from aquatic ancestors and diverged at a relatively early stage during the evolution of the Eukaryota (e. g. Steenkamp et al., 2006; Liu et al., 2009; Lara et al., 2010). Their time of divergence, however, is still a matter of debate. Simon et al. (1993) were the first to apply a molecular clock to a fungal phylogeny. Subsequently, Heckman et al. (2001) estimated that fungi had occupied terrestrial habitats for at least 1000 million years, an estimate which was revised by Sanderson (2003a). However, theses studies did not consider substitution rate variation, a phenomenon now known to be common in many organism lineages. The existence of such variation in the fungal phylogeny was demonstrated by Berbee and Taylor $(1993,2010)$ and is a challenging problem, even under the assumption of relaxed clock models, which are able to accommodate variable substitution rates across individual groups and genes (e. g. Sanderson, 2003b; Drummond and Rambaut, 2006, 2007). Considering the number of ascomycete species and their broad range of morphologies and life-forms they posses, substitution rate heterogeneity is likely to be quite drastic across their phylogeny, even at the class level (Lutzoni and Pagel, 1997; Woolfit and Bromham, 2003; Lumbsch et al., 2008). Besides improving analytical methods of molecular evolution the integration of fossil evidence 
of individual fungal lineages would help to partly overcome this problem (Bebree and Taylor, 2010). Many other studies of molecular evolution showed the importance of constraining molecular clocks with fossil evidence (Benton et al., 2009; Hedman, 2010; Inoue et al., 2010; Magallon, 2010; Pyron, 2010; Wilkinson et al., 2011; Lukoschek et al., 2012; Sauquet et al., 2012). A crucial requirement for the use of fossil evidence as minimum age constrains is their accurate placement to specific nodes in the phylogeny under study (Rutschmann et al., 2007; Marshall, 2008; Forest, 2009; Praham et al., 2012; Pyron, 2010; Dornberg et al., 2011). Reliable assignment of fossil taxa to modern phylogenies requires accurate information about their systematic position and age. In this regard, fossilized fungi preserved in amber and cherts are excellent material as they conserve even delicate micro-structures regardless of their susceptibility to decay (Stankiewicz et al., 1998; Martínez-Delclós et al., 2004). This allows the precise assignment of fossil data to specific phylogenetic nodes.

In order to test their potential use for molecular evolution models of fungi we have evaluated 13 extraordinarily well preserved and precisely dated fossil ascomycetes, which represent the oldest fossil representatives of their respective lineages in several major lineages (Caliciaceae, Parmeliaceae, and Ramalinaceae of the Lecanoromycetes; Laboulbeniaceae of the Laboulbeniomycetes; Metacapnodiaceae and Pleosporaceae of the Dothideomycetes; Trichocomaceae and Venturiaceae of the Eurotiomycetes, in addition to two smaller groups of uncertain position, i.e., the Coniocybaceae and Mycocaliciaceae). The fossil fungi are preserved in amber from various deposits spanning an Albian to Miocene age (about 113 to 17 million years old) as well as in Devonian and Maastrichtian cherts (about 410 and 66.5 million years old, respectively).

Here we have assembled a multi-gene data set with a total of 145 modern taxa representing the main groups of the Ascomycota, and utilized six fossil Pezizomycotina from amber and chert to estimate divergence times of the main classes. We have exclusively used fossil ascomycetes as minimum age constraints and avoided the use of secondary node constraints (age estimates from previous studies). For comparison and to evaluate the influence of our internal node constraints, we also performed an analysis with identical parameter settings but with Paleopyrenomycites as the sole constraint for Pezizomycotina.

This is the first study to combine molecular and fossil data in order to produce a chronogram of the Ascomycota with multiple calibration points solely from within the Ascomycota. Our results show that the integration of minimum age constraints in terminal groups of ascomycete classes significantly affects the estimated divergence times of both early branching nodes and nodes of terminal groups of Ascomycota lineages by pushing them back in time. According to our results the diversification of the Pezizomycotina started in the Cambrian, followed by a continuous diversification throughout the Phanerozoic that was likely unaffected by mass extinctions. 


\section{Material and Methods}

\subsection{Fossil ascomycetes from amber and chert}

Specimens of all available fossil ascomycetes from amber and chert representing the oldest fossil evidences of their respective lineages (Table 1) were reinvestigated considering their potential use as minimum age constraints in molecular models, following the guidelines provided by Praham et al. (2012).

Fossil Lecanoromycetes. Several specimens of Anzia (Rikkinen and Poinar, 2002) are preserved in Baltic amber dating back 55-35 Ma (Fig. 1e). Some of these fossils are morphologically identical to the extant species $A$. japonica which may be the closest living relative. The genus Anzia belongs to the Parmeliaceae (Lecanorales) the largest family of lichen forming fungi and is morphologically very similar to the genus Pannoparmelia (Thell et al., 2010).

Poinar et al. (2000) described two species of Parmelia ( $P$. ambra and $P$. isidiiveteris) from Dominican amber ( $17 \mathrm{Ma}$; Fig. 11). Both fossils clearly belong to the family Parmeliaceae, but they cannot be assigned with certainty to any extant genus. However, neither of the two fossil species represents Parmelia sensu stricto.

A fossil specimen of the genus Phyllopsora (Ramalinaceae, Lecanorales) preserved in Dominican amber ( $17 \mathrm{Ma}$; Fig. $1 \mathrm{~m})$ was described as P. dominicanus by Rikkinen and Poinar (2008). The morphological features of $P$. dominicanus closely resemble those found in modern Phyllopsora species and are very similar to the recent $P$. chlorophaea for example.

A fossil representative of the genus Calicium (Rikkinen, 2003) is preserved in amber of a Baltic deposit dated back 55-35 Ma (Fig. 1g). Species of Calicium (Caliciaceae, Teloschistales) are typical "calicioid lichens", a paraphyletic assemblage of fungi sharing morphological similarities such as stalked fruiting bodies and a powdery spore mass called the mazaedium (Tibell, 1984).

Fossil Dothideomycetes. Several fossils from Mesozoic and Cenozoic amber deposits closely resemble extant species of the genus Metacapnodium (Metacapnodiaceae, Capnodiales; Schmidt et al., in review). These fungi belong to the sooty moulds, a term that is commonly used for an ecological group of saprophytic fungi that live on the surfaces of living plants. Hyphae of Metacapnodium have a characteristic growth form with subglobose cells and gradually tapering apices. The oldest fossil representative of the Metacapnodiaceae is enclosed in Early Cretaceous Charentes amber of France dating 113-100 Ma (Fig. 1b). 
Distinctive conidiophores and a plethora of septate, mostly four-celled and slightly curved conidia are enclosed in a piece of Ethiopian amber (93-95 Ma; Fig. 1c; Schmidt et al., 2010a). The structures are very similar to those of the extant genus Curvularia (Pleosporaceae, Pleosporales) but could also represent a species of some other genus in the family (e.g. Drechslera, Bipolaris, Exserohilum). For this reason the authors did not assign the fossil to a modern genus.

Fossil Eurotiomycetes. Aspergillus collembolorum (Fig. 1f) is preserved in Eocene Baltic amber (50-35 Ma) and was described by Dörfelt and Schmidt (2005). The fossil includes numerous well preserved conidiophores very similar to those of modern species of the Aspergillus flavus group (Trichocomaceae, Eurotiales).

Rikkinen and Poinar (2000) described Chaenothecopsis bitterfeldensis from Bitterfeld amber ( 22 Ma; Fig. 1i). Two further specimens of the same genus were described from Eocene Baltic and Oligocene Bitterfeld amber dating back to 50-35 Ma and 23 Ma, respectively (Tuovila et al., 2012). All three fossils clearly belong to the order Mycocaliciales, which has usually been placed in the Eurotiomycetes (Schoch et al., 2009).

Fossil Sordariomycetes. Gonatobotryum piceae (Dörfelt and Schmidt, 2007) is enclosed in Baltic amber (50-35 Ma; Fig. 1j). The fossil specimen shows close similarities to modern Gonatobotryum fuscum, but developed different conidiophores and mature conidia. Teleomorphs are currently unknown for Gonatobotryum species (Arx, 1981).

The fossil parasite Petropus brachyphylli (Fig. 1d) was described from silicified conifer leaves (Brachyphyllum patens; van der Ham et al., 2003) of Late Maastrichtian chert (66.5 Ma) by van der Ham and Dortangs (2005). P. brachyphylli is considered to be closely related to the extant Phaeocryptopus (Venturiaceae, Venturiales).

Fossil Laboulbeniomycetes. A well-preserved specimen of this highly specialized lineage was found in Bitterfeld amber ( $23 \mathrm{Ma}$; Rossi et al., 2005) and described as Stigmatomyces succini (Fig. 1k). The fossil fungus is attached to the thorax of a stalkeyed fly (Prosphyracephala succini, Diopsidae).

Fossil ascomycetes of groups with ambiguous systematic positions. Paleopyrenomycites devonicus (Fig. 1a) is by far the oldest evidence for ascomycetes. It is enclosed in Devonian Rhynie Chert dating back 410 million years (Taylor et al., 2005). P. devonicus was often assigned to Sordariomycetes, but its exact systematic position is disputed (Taylor et al., 2005; Eriksson, 2005; Padovan et al., 2005; Taylor and Berbee, 2006). An assignment to the Pezizomycetes seems also possible, since Paleopyrenomycites might have produced operculate asci (Lücking et al., 2009).

A well-preserved specimen of Chaenotheca preserved in Baltic amber (55 - $35 \mathrm{Ma}$; Fig. 1h; Rikkinen, 2003;) clearly belongs the Coniocybaceae, but the phylogenetic position of this family remains enigmatic (Tibell, 2001; Tibell and Koffmann, 2002). 
Table 1. List of ascomycete fossils from amber and chert representing the oldest fossil evidence of their respective lineages, including assignment to extant relatives, repository, references for phylogenetic analyses and age. The fossils are arranged by their age (from old to young), Asteriks (*) indicate the fossils used as minimum age constraints in this study as indicated in Fig 2.

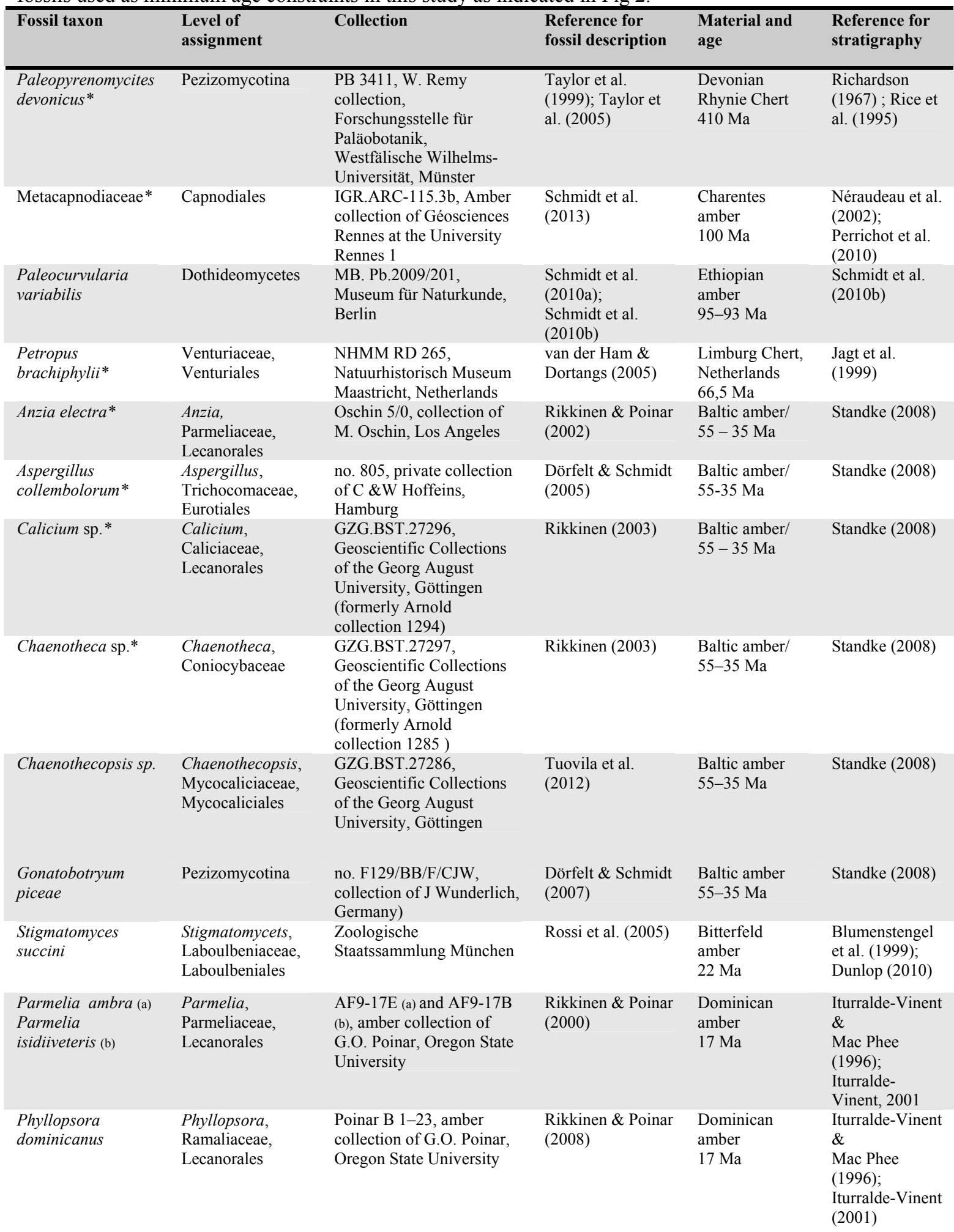



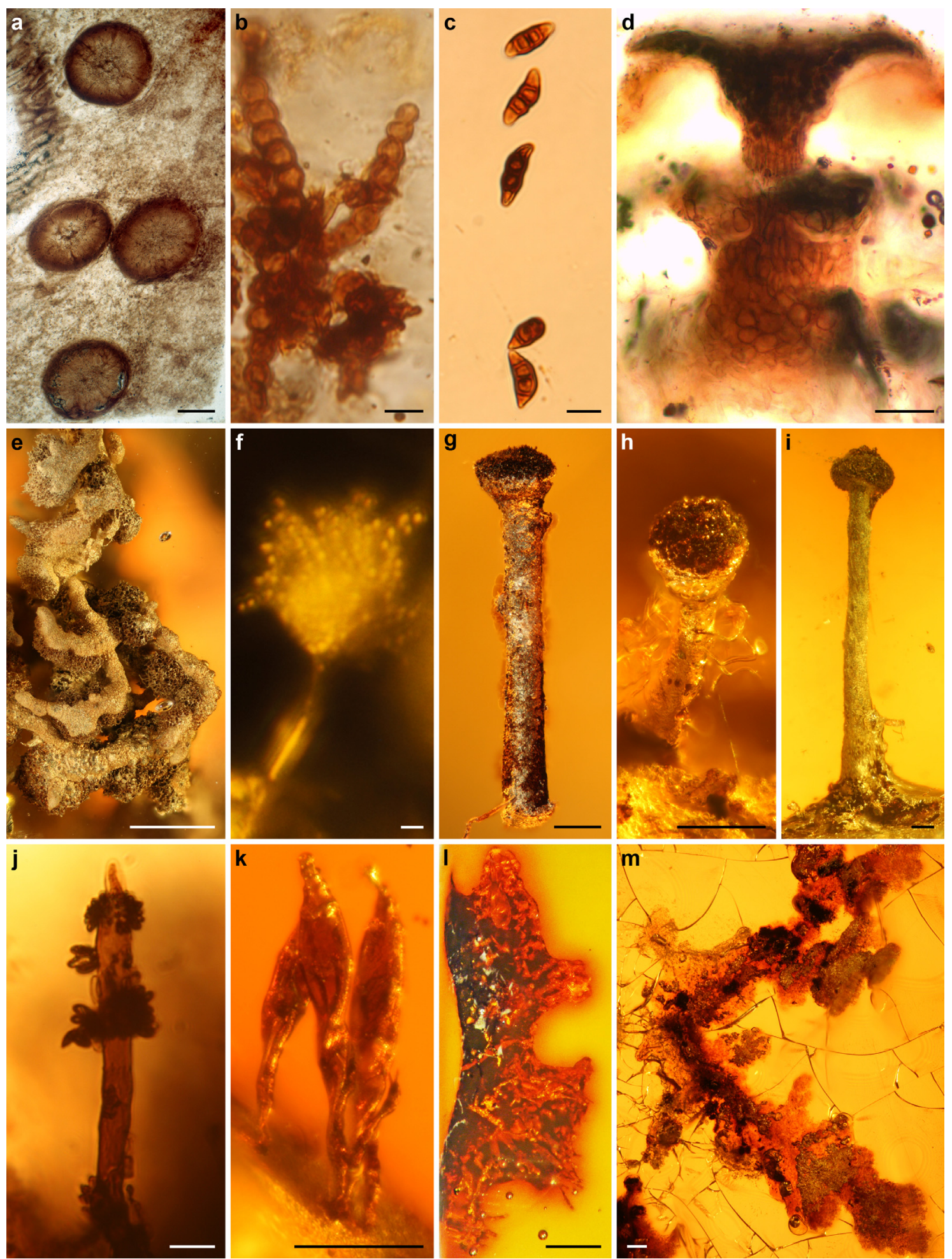

Fig. 1. Fossil ascomycetes from amber and chert representing the oldest known ancestors of respective lineages. (a) Perithecia of Paleopyrenomycites devonicus from Lower Devonian (Pragian) Rhynie Chert. W. Remy collection PB 3411. Courtesy of Hans Kerp (University of Münster. (b) Moniliform hyphae of a Metacapnodiaceae representative from Lower Cretaceous (Albian) Charentes amber. IGR.ARC-115.3b. (c) Conidia of Palaeocurvularia variabilis from Upper Cretaceous (Cenomanian) Ethiopian amber. MB. Pb. 2009/200. (d) Hypostroma of Petropus brachyphylli from Maastrichtian chert from the Netherlands. NHMM RD 265. Courtesy of Raymond W. J. M. van der Ham (Naturalis Biodiversity Center, Leiden). (e) Anzia electra from Eocene Baltic amber. Hoffeins 950-1. (Continues below) 
Continuation Fig. 1. (f) Sporulating conidiophore of Aspergillus collembolorum on a springtail from Eocene Baltic amber. Hoffeins 805. (g) Ascoma of Calicium sp. from Eocene Baltic amber. GZG.BST.27296. (h) Ascoma of Chaenotheca sp. on remnant bark in Eocene Baltic amber. GZG.BST.27297. (i) Ascoma of a resinicolous Chaenothecopsis sp. from Eocene Baltic amber. GZG.BST.27286. (j) Sporulating conidiophore of Gonatobotryum piceae on a conifer seedling from Eocene Baltic amber. Wunderlich F129. (k) Three thalli of Stigmatomyces succini on a dipteran from Oligocene Bitterfeld amber. Zoologische Staatssammlung München, sine numero. (l) Parmelia ambra from Miocene Dominican amber. Poinar AF9-17E. Courtesy of George O. Poinar, Jr. (Corvallis). (m) Phyllopsora dominicanus from Miocene Dominican amber. Poinar B 1-23. Scale bars: $10 \mu \mathrm{m}$ (b-d, f, and j), $100 \mu \mathrm{m}(\mathrm{a}, \mathrm{g}-\mathrm{i}, \mathrm{k}$, and $\mathrm{m})$, and $1 \mathrm{~mm}$ (e and $\mathrm{l}$ ).

\subsection{Taxon sampling for phylogenetic reconstruction and molecular work}

For this study we used the small and large ribosomal subunit (SSU and LSU respectively) and RNA polymerase II protein coding genes RPB1 and RPB2 as implemented in a previous study by James et al. (2006). Sequences were obtained from cultured strains ordered from the CBS (Centraalbureau voor Schimmelcultures, Utrecht) and JMRC (Jena Microbial Resource Collection) and from Genbank. Additional fungi were collected from localities in Finland (2009) and New Caledonia (2011). The resulting taxon set consists of 145 species representing all the main groups of the Ascomycota. Accession numbers of all sequences are provided in Table S1 (see Beimforde et al. (submitted) [6]). For protein coding and ribosomal genes, we isolated DNA from fungal material using the Invisorb Spin Plant Mini Kit (Invitek, Berlin, Germany) and NucleoSpin@Plant DNA extraction kit (Macherey-Nagel) with the following modification to the manufacturer's protocol: some specimens were incubated up to $2 \mathrm{~h}$ to ensure the lysis of the ascocarps. PCR reactions were carried out with fungal specific primers: SSU ribosomal genes were amplified with the primers NS1, NS2, NS3, NS4 (White et al., 1990) and NS24 (Gargas and Taylor, 1992); LSU ribosomal genes were amplified with LR0 (Rehner and Samuels, 1994), LR3R (Mioncalvo et al., 2000) LR5 and LR7 (Vilgalys and Hester, 1990). Genes coding for the RNA polymerase II were amplified with the primers RPB1-AFasc, RPB1-6R2asc, RPB1DF2asc, RPB1-G1Rasc and RPB1G2R (Hofstetter et al., 2007) for the largest subunit and fRPB2-5f, FRPB2-7cf, fRPB2-7cR, fRPB2-11aR and RPB2-11bR (Liu et al., 1999) for the second largest subunit. PCR reactions were performed according to the protocols listed in respective reference for mentioned primers. In case of melanin inhibiting the PCR, the DNA-templates were diluted up to 5000 fold sometimes with the addition of $200 \mathrm{ng} / \mu 1$ bovine serum albumin (BSA) (Kreader, 1996). PCR products were purified using PCRapace (Invitek, Berlin, Germany). All PCR products were sequenced in both directions with a MegaBACE 1000 automated sequencing machine and DYEnamic ET 
Primer DNA Sequencing Reagent (Amersham Biosciences, Little Chalfont, UK). All sequences were assembled and edited using Bioedit 5.0.9 (Hall, 1999) and Seaview 4 (Gouy et al., 2010).

\subsection{Initial phylogenetic Analysis}

Datasets for each gene (SSU, LSU, RPB1 and RPB2) were aligned separately using MAFFT version 6 (Katoh and Toh, 2008) with subsequent manual adjustment to minimize the number of possible false homologies using Bioedit 5.0.9. (Hall, 1999) and Seaview 4 (Gouy et al., 2010). Unalignable regions and introns were excluded by using the mask function in Bioedit 5.0.9. Best fitting substitution model for each gene were chosen separately from seven substitution schemes included in the software package jModeltest 2.1.1 (Darriba et al., 2012, 2008), and models were chosen according to the Bayesian information criterion (BIC, Schwartz, 1939). The Bayesian information criterion (BIC, Schwartz, 1978) supported the TrN + G model as the best fit for LSU, the $\mathrm{SYM}+\mathrm{G}$ for SSU, and GTR $+\mathrm{G}$ for RPB1 and RPB2. Topological congruence of the four datasets was assessed by visual comparison of phylogenetic trees obtained from maximum likelihood-based analysis with RaxML (Stamatakis et al., 2008), and all genes were subsequently combined in a super matrix using Bioedit 5.0.9. Bayesian analyses were carried out using Markov chain Monte Carlo (MCMC) in MrBayes 3.1.2 (Ronquist and Huelsenbeck, 2003) to generate a reasonable starting tree for subsequent analyses of divergence date estimates in BEAST. Analyses were run using four chains for 10 million generations each, sampling parameters every $1,000^{\text {th }}$ generation. All analyses were performed on the freely available computational resource CIPRES (www.cipres.org). Average standard deviations of split frequency (ASDSF) lower than 0.01 were interpreted as indicative of independent MCMC convergence.

\subsection{Fossil calibrations}

The placement of the fossil Paleopyrenomycetes (Fig. 1a) is challenging since its exact systematic position is not clear (Taylor et al., 2005; Lücking et al., 2009; Taylor and Berbee, 2006). The previously discussed possibilities for its placement include anywhere in the Pezizomycotina stem lineage, Pezizomycotina crown group, or members of the Pezizomycotina building operculate asci (Lücking et al., 2009). For our evolutionary model we adopted a conservative view and placed Paleopyrenomycites on the crown group of Pezizomycetes, thus assuming the common ancestor of all filamentous, sporocarp-producing Ascomycota (Pezizomycotina) to be at least $400 \mathrm{Ma}$. We decided to model the uncertainty of the group by applying a truncated normal 
distribution with an upper hard bound (truncation) set to $400 \mathrm{Ma}$, corresponding to the mean of the normal distribution with a standard deviation (SD) of 150, providing an upper $97.5 \%$ credibility interval (CI) of $700 \mathrm{Ma}$. This mode of calibration associates an increased uncertainty with the immediate upper bound, allowing a more generous interpretation of the age of a group compared to that of an exponential decay. Based on the fossil Petropus brachiphylii (Fig. 1d; van der Ham and Dortangs, 2005) we constrain the common ancestor of Venturiaceae to a hard upper bound of 66.5 Ma, modeling the uncertainty with a truncated normal distribution (mean $=66.5, \mathrm{SD}=50$, $\mathrm{CI}=166.5 \mathrm{Ma}$ ). The fossil Anzia electra (Fig. 1e; Rikkinen and Poinar 2002) was used to calibrate the split between Anzia and other groups of parmeloid lichens here presented by Canoparmelia constraining the node to $35 \mathrm{Ma}$ with a truncated normal distribution to model the uncertainty (mean $=35, \mathrm{SD}=50, \mathrm{CI}=135$ ). Based on the fossil Calicium (Fig. 1g; Rikkinen et al., 2003) we constrain the common ancestor of Calicium viride and C. salicium, which are both morphologically indistinguishable from the fossil to $35 \mathrm{Ma}$ (truncated normal distribution, mean $=35, \mathrm{SD}=50, \mathrm{CI}=135$ ). Using the fossil Aspergillus collembolorum (Fig. 1f; Dörfelt and Schmidt, 2005) we constrain the common ancestor of Aspergillus to $35 \mathrm{Ma}$ (truncated normal distribution, mean $=35, \mathrm{SD}=50, \mathrm{CI}=135$ ). The fossil Metacapnodiaceae (Fig 1b; Schmidt et al., in review) gave rise to the hypothesis of the common ancestor of the order Capnodiales to be constrained to an age of $100 \mathrm{Ma}$ (truncated normal distribution, mean $=100, \mathrm{SD}=$ 150, CI = 400). All analyses of divergence time estimates using the above set of constraints were first run on empty alignments to check for cross prior influence, while constraining all calibrated nodes to monophyly.

\subsection{Divergence time estimates}

Subsequent divergence time analyses were carried out using BEAST 1.7.4 (Drummond et al., 2012). Separate partitions for each included gene were created with BEAUti 1.7.4 (BEAST package). To accommodate for rate heterogeneity across the branches of the tree (e. g. Berbee and Taylor, 2010) we used an uncorrelated relaxed clock model (Drummond et al., 2006) with a lognormal distribution of rates for each gene estimated during the analyses. A birth/death tree prior accommodating for incomplete sampling (Stadler, 2009) was used to model the speciation of nodes in the topology, with uniform priors on probability of splits and extinctions. To avoid using uninformative priors on the clock models we used vague priors on the substitution rates for each gene (exponential decays with mean 0.1 in units of substitutions per site per time unit). To ensure congruence we ran the analyses five times for 100 million generations each, sampling parameters every 25,000 generations, assessing convergence and sufficient chain mixing (Effective sample sizes $>200$ ) using Tracer 1.5 (Rambaut and Drummond, 
2009). After removal of a proportion of each run as burn-in the remaining trees were combined using LogCombiner (part of the BEAST-package), and summarized as maximum clade credibility (MCC) trees in TreeAnnotator (part of the BEASTpackage), and visualized using FigTree (Rambaut, 2006 - 9, http://tree.bio.ed.ac.uk/ software/figtree/).

\section{Results}

\subsection{Topology and divergence times of the Ascomycota phylogeny}

The topologies resulting from the BEAST analyses (Fig. 2 and Fig. S1) are generally congruent with the results reported by James et al. (2006). Except of the placement of Pezizomycetes basal to Orbiliomycetes, which is opposite, in some recent papers (Ebersberger et al., 2012) or at least discussed (Kumar et al., 2012). The only difference between our two inferred topologies (Fig. 2 and supplementary Fig.1) is the placement of Eurotiomycetes, which groups in the single-constrained tree as a sister clade to Mycocaliciaceae with 0.99 posterior probability (pp), but in the multi-constraint tree groups as sister to a clade consisting of Arthoniomycetes and Dothideomycetes (0.95 pp). Pezizomycetes constitutes the first order sister clade to remaining representatives of Pezizomycotina with strong support (1.0 pp). The next order of sister groups are the Orbiliomycetes, but in a position only indicated by the node support ( 0.91 vs. $0.8 \mathrm{pp})$. A second order sister group consists of the Arthoniomycetes-Dothiomycetes-clade, which in the single-constraint analysis receives unanimous support $(1.0 \mathrm{pp})$, but in the multiconstraint analysis groups together with the ambiguous Eurotiomycetes with strong support $(0.95 \mathrm{pp})$. The remaining representatives of the Pezizomycotina split in two well-supported clades (1.0 vs. $0.91 \mathrm{pp})$. The first consists of the Coniocybaceae together with Lichinomycetes (1.0 vs. 0.99 pp), with the Geoglossomycetes as sister group (0.99 vs. $0.98 \mathrm{pp}$ ). As sister group to the Geoglossomycetes-Coniocybaceae-Lichinomycetes clade, is the Mycocaliciaceae-Lecanoromycetes-alliance, which in the singleconstrained analysis also consists of Eurotiomycetes, then with unanimous support (1.0 pp). This position is also congruent with previous studies (e.g. Schoch et al., 2009). The second clade consists of the Leotiomycetes and Sordariomycetes grouping together with unanimous support (1.0 pp). Also, the genus Leotia, believed to be the most basal member of the Leotiomycetes, here group together with the sister clade of Soradariomycetes with unanimous support (1.0 pp). 


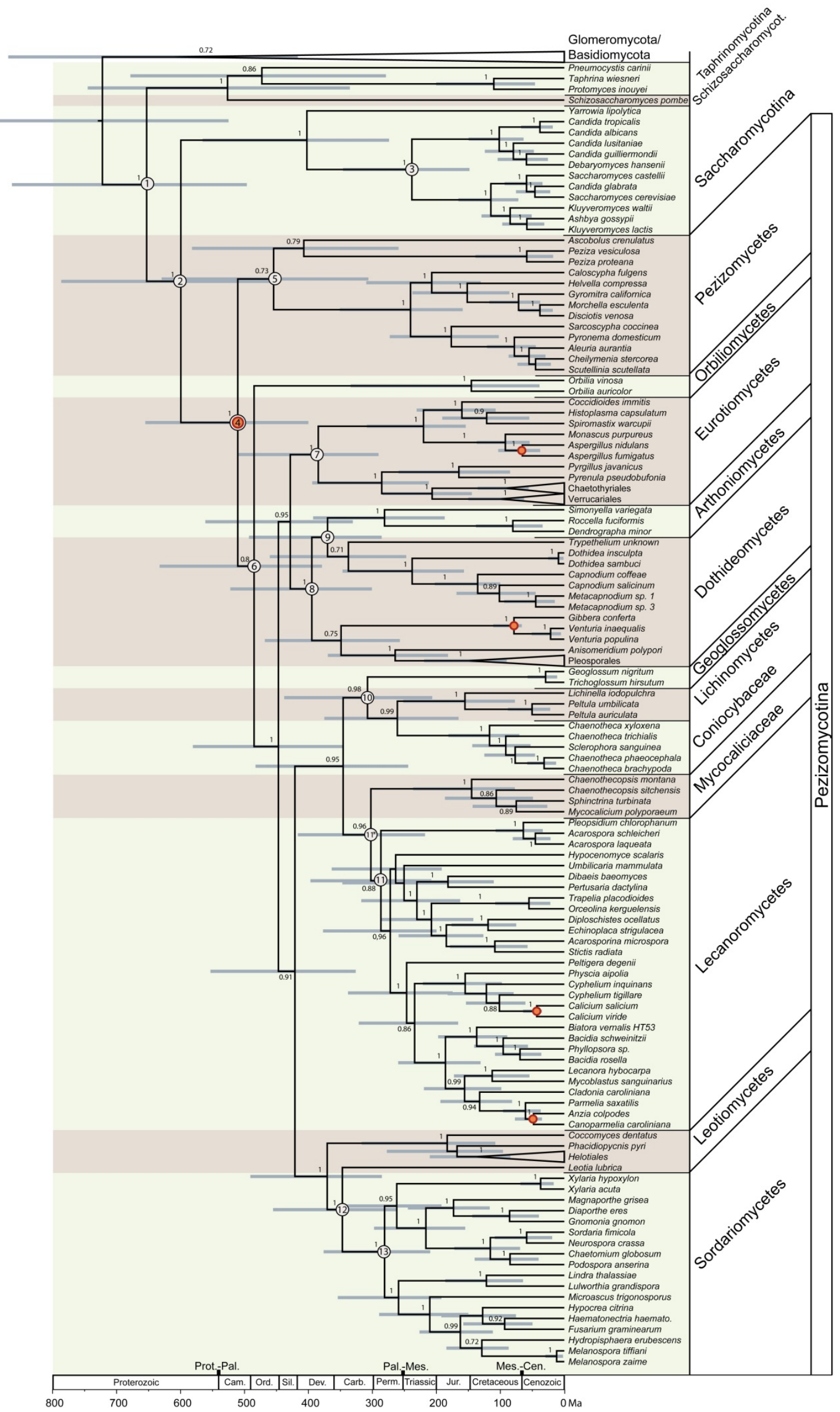


Fig. 2. Maximum clade credibility (MCC) tree with divergence time estimates for main groups of the Ascomycota obtained from a Bayesian approach (BEAST) using six fossil minimum age constraints. Numbers at nodes indicate posterior probabilities (pp) for node support. Bars correspond to the $95 \%$ highest posterior density (HPD) intervals. For estimated median ages of numbered nodes, see Table 3. Assignments in the tree of the fossil minimum age constraints are marked with red circles. Geological periods are abbreviated as: Cam. $=$ Cambrian, Ord. = Ordovician, Sil. $=$ Silurian, Dev. = Devonian, Carb. $=$ Carboniferous, Perm. $=$ Permian, Jur. $=$ Jurassic.

\subsection{Divergence time estimations using six internal calibrations}

Divergence time estimates using all six fossil calibration points are also shown in Fig. 2, with horizontal blue representing the $95 \%$ highest posterior density (HPD) intervals for each node. Comparable results from both analyses (Fig. 2 and Fig. S1) are listened in Table 3. According to our analyses, the Ascomycota diverged from Basidiomycota in the Neoproterozoic, about $722 \mathrm{Ma}$ (525-987 Ma, 95\% HPD interval). The subphylum Pezizomycotina, containing all fruiting body forming members of the Ascomycota split from Saccharomycotina around $600 \mathrm{Ma}$ (458-787). The earliest split in the Pezizomycotina (Pezizomycetes from the rest of the Pezizomycotina) occurred in the Cambrian, around $511 \mathrm{Ma}$ (400-655). Within the Pezizomycotina, the Orbiliomycetes diverged $485 \mathrm{Ma}$ (378-632), at the beginning of the lower Ordovician. The Sordariomycetes diverged from the lineage of Leotia lubrica by the early Carboniferous, around 346 Ma (261-455). Eurotiomycetes and Dothideomycetes + Arthoniomycetes diverged in the Upper Ordovician, around $447 \mathrm{Ma}$ (344-580). The earliest split in the Eurotiomycetes (Eurotimycetes crown group) occurred in the Devonian, around $385 \mathrm{Ma}(290-510)$, and in the Dothideomycetes around $395 \mathrm{Ma}$ (301-522). Lecanoromycetes diverged from other Pezizomycotina classes $302 \mathrm{Ma}$ (218-417). Mycocaliciales have arisen in the Carboniferous $346 \mathrm{Ma}$ (244-483) and the Lichinomycetes in the Permian, $261 \mathrm{Ma}$ (165-375). The family Coniocybaceae diverged from Lichinomycetes approximately $260 \mathrm{Ma}(165-375)$.

\section{Discussion}

\subsection{Systematic assignment of fossil fungi}

A crucial issue in molecular dating studies is the interpretation of morphological characters used to assign fossils to particular nodes in the phylogenies (Rutschmann et al., 2007; Marshall, 2008; Forest, 2009; Praham et al., 2012; Pyron, 2010; Dornberg et al., 2010; Feldberg et al., 2013). The use of morphological data to reconstruct the evolution of lineages through time can be limited due to homoplasy. Ascomycetes show 
many cases of parallel evolution in both vegetative and reproductive structures (e.g. Lumbsch, 2000; Schoch et al., 2009). In this study we have only used fossils which we believe to represent extant families or genera (with the exception of Paleopyrenomycites which was assigned to Pezizomycotina). However, some level of uncertainty will always remain when working with fossil material. Besides Paleopyrenomycites devonicus we ended up using fossils assigned to five extant groups of Ascomycetes (Metacapnodiaceae, Anzia electra, Aspergillus collembolum, Calicium and Petropus brachiphylii; Table 1, Fig. 1) which provided minimum ages for the split of the lineage from its sister group. The remaining seven fossils (Fig. 1; Table 1) did not provide suitable minimum age constraints. This was mainly due to insufficient taxon sampling of our molecular data. While we could not use all of the twelve available fossils in our study, all of them are potentially of value for further studies in fungi with denser taxon samplings, or focus on the evolution of individual groups of ascomycetes.

Table 2. Divergence time estimates of Ascomycota lineages obtained from Bayesian analysis using either Paleopyrenomycites as single calibration or together with 5 additional calibrations from amber and chert (Metacapnodiaceae, Anzia electra, Aspergillus collembolum, Calicium and Petropus brachiphylii; Table 1, Fig. 1). For each divergence, the median and the 95\% Highest Posterior Density are provided. Divergence times are provided in millions of years (Ma). The node numbers correspond to numbers used in Fig. 2 to show their placement in the chronogram. Asteriks (*) indicate that the Mycocaliciales are included.

\begin{tabular}{|c|c|c|c|c|c|}
\hline \multirow[t]{2}{*}{ Nodes } & & \multicolumn{2}{|c|}{ One calibration } & \multicolumn{2}{|c|}{ Six calibrations } \\
\hline & & $\begin{array}{l}\text { Geological } \\
\text { Period } \\
\end{array}$ & $\begin{array}{l}\text { Time } \\
\text { (Ma) }\end{array}$ & $\begin{array}{l}\text { Geological } \\
\text { Period } \\
\end{array}$ & $\begin{array}{l}\text { Time } \\
\text { (Ma) }\end{array}$ \\
\hline 1 & Ascomycota crown group & - & - & Proterozoic & $653(496-864)$ \\
\hline 2 & $\begin{array}{l}\text { Pezizomycotina- } \\
\text { Saccharomycotina }\end{array}$ & - & - & Proterozoic & $600(458-786)$ \\
\hline 3 & Candida-Saccharomyces & - & - & Triassic & $238(148-345)$ \\
\hline 4 & Pezizomycotina crown group & Ordovician & $444(400-576)$ & Cambrian & $511(400-655)$ \\
\hline 5 & Pezizomycetes crown group & Devonian & $408(262-543)$ & Ordivician & $454(306-629)$ \\
\hline 6 & $\begin{array}{l}\text { Orbiliomycetes-other } \\
\text { Pezizomycotina }\end{array}$ & Devonian & $407(328-534)$ & Ordovician & $485(378-632)$ \\
\hline $\begin{array}{l}7 \\
7 *\end{array}$ & $\begin{array}{l}\text { Eurotiomycetes crown group } \\
\text { Eurotiomycetes crown group } \\
\text { including Mycocaliciales }\end{array}$ & Carbon. & $\begin{array}{l}282(215-382) \\
311(240-420)^{*}\end{array}$ & Devonian & $385(290-510)$ \\
\hline 8 & Dothideomycetes crown group & Carbon. & $385(263-450)$ & Devonian & $395(301-522)$ \\
\hline 9 & $\begin{array}{l}\text { Dothideomycetes- } \\
\text { Arthoniomycetes }\end{array}$ & Carbon. & $335(263-450)$ & Devonian & $370(286-493)$ \\
\hline 10 & $\begin{array}{l}\text { Lichinomycetes-other } \\
\text { Pezizomycotina }\end{array}$ & Permian & $246(164-355)$ & Permian & $261(165-375)$ \\
\hline $\begin{array}{l}11 \\
11^{*}\end{array}$ & $\begin{array}{l}\text { Lecanoromycetes crown group } \\
\text { Lecanoromycetes crown group } \\
\text { including Mycocaliciales }\end{array}$ & Permian & $260(190-356)$ & $\begin{array}{l}\text { Permian } \\
\text { Carbon. }\end{array}$ & $\begin{array}{l}286(208-397) \\
302(218-417)^{*}\end{array}$ \\
\hline 12 & $\begin{array}{l}\text { Sordariomycetes- } \\
\text { Leotiomycetes }\end{array}$ & Permian & $287(234-388)$ & Carbon & $346(261-455)$ \\
\hline 13 & Sordariomycetes crown group & Triassic & $233(182-316)$ & Permian & $281(210-376)$ \\
\hline
\end{tabular}

Gueidan et al. (2011) used Paleocurvularia (Fig. 1c; Schmidt et al., 2010a, b) to constrain the split between Arthoniomycetes and Dothideomycetes. However, the fossil is represented by numerous conidia and related conidiophores, which resemble those produced by modern species of Curvularia but also those of Bipolaris, Drechslaria, and 
Exserohilum. Since fragments of the possible teleomorph are poorly preserved, and the fossil conidia are more variable than those of any of the modern genera, Schmidt et al. $2010 \mathrm{~b}$ and Gueidan et al. (2011) avoided an assignment of the fossil to any modern family. Currently, in order to avoid a false assignment, we had to exclude Paleocurvularia from our analyses.

Gonatobotryum pieceae (Fig. 1j; Dörfelt and Schmidt, 2007) was also excluded, because of the ambiguous phylogenetic position of this genus (Arx, 1981). The morphologically similar fossil Gonatobotrys primigenia (Caspary and Klebs, 1907) likely represents a species of Gonatobotryum rather than Gonatobotrys. As the modern genus Melanospora (Ceratostomataceae, Sordariomycetes) is known as the teleomorph of Gonatobotrys (Vakili, 1989), this genus could potentially be used for calibration. A confident assignment of Gonatobotrys primigenia would require a re-investigation, however, this fossil which was part of the Künow collection of Berlin's Museum of Natural History is lost without any trace. Both fossils are well preserved and might serve as calibration constraints once their position within the ascomycetes has been clarified.

Stigmatomyces succini (Fig. 1k; Rossi et al., 2005) was also not used in our study although the fossil is well dated and confidently assigned to the genus Stigmatomyces (Laboulbeniomycetes). Species of this ectoparasite class display distinct morphologies and their phylogenetic position has long been unclear, but Schoch et al. (2009) have recently proposed a sister relationship of Laboulbeniomycetes to Sordariomycetes. Primary analyses including sequences of the Laboulbeniomycetes indicated the introduction of substantially long branches in resulting phylogenies (data not shown), and was therefore excluded from further analyses to avoid introducing unnecessary bias into the branch length estimates.

The fossils Parmelia ambra (Fig. 11) and P. isidiiveteris (Poinar et al., 2000) cannot with confidence be assigned to particular genera within the foliose parmelioid lichens ("Parmelia sensu lato"). We were anyway unable to use Parmelia because it would imply a constraint on the divergence of Parmelia and Canoparmelia, or Anzia, to a minimum of $\sim 17 \mathrm{Ma}$. As we had already used Anzia electra (55-35 Ma; Rikkinen and Poinar, 2002) to constrain the split of Anzia and Canoparmelia, an integration of the much younger fossil of parmelioid lichens would introduce redundancy. Similar reasons led to the exclusion of Phyllopsora dominicanus (Fig. 1m; Rikkinen \& Poinar 2008) as an age constraint in our analysis. Our Phyllopsora sequences grouped together with Bacidia and constraining the divergence between these two genera to a minimum of only $\sim 17$ Ma would not have been realistic (Printzen \& Lumbsch, 2000; Rikkinen \& Poinar, 2008).

The fossils Chaenotheca (Rikkinen, 2003), and Chaenothecopsis (Rikkinen and Poinar 2000; Touvila et al., 2013) were discarded from the analyses despite being of 
good quality. Initial tests for cross-prior influence on the age estimates of nodes indicated that the introduction of these constraints resulted in several other constraints showing bimodal posterior distributions. Exact explanations of such phenomena can be difficult to achieve, but an explanation based on discordance between the fit of the tree prior and one or more node constraints is plausible. Removal of the mentioned fossils indicated substantial performance improvements across the tree, validating the decision for removal. These difficulties might be due to their uncertain phylogenetic positions. Several studies deal with the relationships and photobiont association of the genus Chaenotheca and family Coniocybaceae. However, the phylogenic position of Chaenotheca remains enigmatic. As the family could not be assigned to any group of ascomycetes so far and it is treated as incertae sedis (Lumbsch and Huhndorf 2010). In our phylogeny Chaenotheca grouped with Lichinomycetes with strong support (0.99 pp). The Lichinomycetes (Reeb et al., 2004) are also lichen symbiotic and are currently thought to include two orders (Lichinales and Eremithallales). Species of Lichinales associate with cyanobacteria and Eremithallales with green algae of the Trentepohliales (Lücking et al., 2008). Also some species of Chaenotheca and all species of Sclerophora are known to associate with Trentepohlia (e.g. Tibell, 2001). Species of Eremithallales and many species of Coniocybaceae also tend to associate with photobionts that are submerged into the substrate.

Recent phylogenetic studies have usually indicated that species of Chaenothecopsis and other fungi of the Mycocaliciales would be related to the Eurotiomycetes (Schoch et al., 2006; Hibbett et al., 2006). Geiser et al. (2006) established the subclass Mycocaliciomycetidae as sister group to Eurotiomycetidae and Chaetothyriomycetidae, but did not include this group into Eurotiomycetes because of the limited data used to infer its phylogenetic placement (only SSU and LSU data). However, this placement was later validated by Hibbett et al. (2007). Interestingly, our analyses confirmed a relationship with Eurotiomycetes when using only ribosomal genes (data not shown) but refuted it when also protein coding genes were used. The analysis based on both ribosomal and protein coding genes indicate a relationship of Mycocaliciales (Mycocaliciomycetidae) and Lecanoromycetes (Fig. 2).

\subsection{The impact of internal node constraints on estimated divergence times of Pezizomycotina classes}

Some studies have evaluated the variation resulting from different calibration strategies in fungal phylogenies (Berbee and Taylor, 2006; Lücking et al., 2009; Padovan et al., 2005), but none of them evaluated the impact of internal node constraints on models of fungi molecular evolution. Compared to the sole use of the Devonian 
Paleopyrenomycites, the use of five calibrations from Mesozoic and Cenozoic Pezizomycotina crown group fossils (of Dothideomycetes, Eurotiomycetes and Lecanoromycetes) in addition to the Devonian fossil resulted in older age estimates (Table 2). Using multiple age constraints, the first split in the Pezizomycetes is estimated to have occurred in the Cambrian 511 Ma (400-655), rather than in the Ordovician 444 Ma (400-576). The divergence of Orbiliomycetes and Pezizomycetes occurred about 80 million years earlier when the additional constraints are considered. All other Pezizomycotina classes have diverged from the Orbiliomycetes close to the Ordovician-Silurian boundary $485 \mathrm{Ma}$ (378-632), rather than in the late Devonian some 407 (328-534) Ma. The unresolved relationships between Eurotiomycetes, Lecanoromycetes, Dothideomycetes and Lichinomycetes prevent a comparison of the divergence times of these Pezizomycotina classes, but allow a comparison of corresponding crown groups; these divergence estimates are significantly earlier when using additional age constraints (Table 2).

Besides affecting the divergence times of early Ascomycota lineages, the integration of additional age constraints resulted in older age estimates of more recent ascomycete groups (terminal nodes). These effects are not only restricted to branches associated with fossil age constraints, although adjacent branches are slightly stronger affected, supporting the observations of Berbee and Taylor (2010).

Our results show that the use of fossil age constraints (even if relatively young) in terminal groups of ascomycetes (genus and species level) significantly affect the estimated divergence times of both early branching nodes and terminal groups of Ascomycota lineages. This effect was also observed when using different BEAST parameters, e.g. unconstrained uniform probability distributions to model age uncertainties of groups associated with fossils (data not shown).

\subsection{Comparisons to previous studies}

Compared to earlier studies our data indicated either much younger (Bebree and Taylor, 1993) or much older (Heckman et al., 2001), age estimates of Ascomycota lineages. Our results are generally more congruent with the estimates of recent studies (Padovan et al., 2005; Berbee and Taylor; Lücking et al., 2009; Gueidan et al., 2011) (Table 3).

One likely explanation is that molecular clock methods have improved by developing relaxed molecular clock models, which allow for more flexible modeling of rate heterogeneity across phylogenetic trees (e. g. Sanderson, 2003b; Drummond and Rambaut, 2006, 2012). Additionally, more well resolved fungal phylogenies have recently been established (e. g. Spatafora et al., 2006; Schoch et al., 2009, Miadlikowska et al., 2006; Hibbett et al., 2007; Eversberger et al., 2012; Kumar et al., 2012, Morgenstern et al., 2012). Advances in both fields of research have enabled the 
establishment of increasingly realistic models of evolution for fungi compared to earlier studies, resulting in different age estimates (e. g. Simon et al., 1993; Heckmann et al., 2001).

Table 3. Comparison of divergence time estimates from our analyses with previous studies (Berbee \& Taylor 1993; Heckman et al. 2001; Douzery et al. 2004; Padovan et al. 2005; Lücking et al. 2009; Taylor \& Berbee 2006) in millions of years (Ma) which also used Paleopyrenomycites as fossil age constraints. For divergence times, only the medians are listed. Node numbers correspond to numbers used in Fig. 2 and supporting figure 1 to show their placement in the chronogram. triangle $\left({ }^{\Delta}\right)$ marks the assignment of Paleopyrenomycites; psi $\left({ }^{\psi}\right)$ indicates studies that also used external (non ascomycotan or non-fungal) calibrations; phi $\left({ }^{\Phi}\right)$ recalibration study, omega $\left({ }^{\Omega}\right)$ study used ascomycotan, non-ascomycotan and nonfungal calibrations; asteriks $(*)$ show the divergence time of Eurotiomycetes crown or Lecanoromycetes crown including Mycocaliciales.

\begin{tabular}{|c|c|c|c|c|c|c|c|c|c|c|c|}
\hline Nodes & \multicolumn{2}{|c|}{ This study } & $\begin{array}{l}\text { Heck- } \\
\text { man et } \\
\text { al. } \\
(2001)^{\psi}\end{array}$ & \multicolumn{2}{|c|}{$\begin{array}{l}\text { Padovan et al. } \\
(2005)\end{array}$} & \multicolumn{4}{|c|}{ Berbee \& Taylor (2006) } & $\begin{array}{l}\text { Lücking } \\
\text { et al. } \\
(2009)^{\Phi}\end{array}$ & $\begin{array}{l}\text { Gueidan } \\
\text { et al. } \\
(2010)^{\Omega}\end{array}$ \\
\hline $\begin{array}{l}\text { Ascomycota crown } \\
\text { group }\end{array}$ & - & 653 & 1144 & 1148 & 724 & 1316 & 745 & 652 & $400^{\Delta}$ & - & 538 \\
\hline $\begin{array}{l}\text { Candida- } \\
\text { Saccharomyces }\end{array}$ & - & 238 & 841 & - & - & - & - & $\sim 140$ & $\sim 90$ & - & 207 \\
\hline $\begin{array}{l}\text { Pezizomycotina } \\
\text { crown group }\end{array}$ & $444^{\Delta}$ & $511^{\Delta}$ & - & 972 & 569 & 707 & $400^{\Delta}$ & $400^{\Delta}$ & 215 & $\begin{array}{l}320-400 \\
\Delta\end{array}$ & $455^{\Delta}$ \\
\hline $\begin{array}{l}\text { Pezizomycetes } \\
\text { crown group }\end{array}$ & 408 & 454 & - & $\sim 900$ & $\sim 500$ & - & - & - & - & - & $\sim 310$ \\
\hline $\begin{array}{l}\text { Eurotiomycetes } \\
\text { crown group }\end{array}$ & $\begin{array}{l}282 \\
311^{*}\end{array}$ & 385 & - & - & - & - & - & - & - & $270-350$ & 341 \\
\hline $\begin{array}{l}\text { Dothideomycetes } \\
\text { crown group }\end{array}$ & 321 & 395 & - & - & - & - & - & & - & - & 338 \\
\hline $\begin{array}{l}\text { Dothideomycetes- } \\
\text { Arthoniomycetes }\end{array}$ & 335 & 370 & - & - & - & & - & - & - & - & 362 \\
\hline $\begin{array}{l}\text { Lecanoromycetes } \\
\text { crown group }\end{array}$ & 260 & $\begin{array}{l}286 \\
302 *\end{array}$ & - & 816 & 453 & - & - & - & - & $280-330$ & 322 \\
\hline $\begin{array}{l}\text { Sordariomycetes- } \\
\text { Leotiomycetes }\end{array}$ & 287 & 347 & - & - & - & - & - & - & - & $290-280$ & $\sim 340$ \\
\hline $\begin{array}{l}\text { Sordariomycetes } \\
\text { crown group }\end{array}$ & 233 & 281 & $400^{\Delta}$ & $653^{\Delta}$ & $400^{\Delta}$ & $400^{\Delta}$ & 226 & 211 & 122 & - & 229 \\
\hline
\end{tabular}

Despite these improvements in methodology and data sampling, age estimates are not fully consistent across recent studies. Such discrepancies are likely to have various reasons such as inability to properly model evolutionary rates, parameter settings for the applied relaxed clock models, unequal taxon sampling, and choice of genes under study. Such differences make it difficult to compare inferred age estimates of individual studies. Another possible source for inconsistent age estimates in earlier studies is the assignment of the fossil Paleopyrenomycites devonicus (Taylor et al., 1999, 2005). This fossil constitutes a highly influential constraint, and since it became available has been used in all studies of fungal molecular evolution (Table 3). In early studies the fossil 
was interpreted as belonging to the Sordariomycetes (e.g., Heckmann et al., 2001). More recent studies used Paleopyrenomycites to calibrate the Pezizomycetes crown or stem group (Berbee and Taylot 2006; Lücking et al., 2009), the Ascomycota crown group (Berbee and Taylor, 2006), or even as constraint for the split between Leotiomyceta and Pezizomycotina (Gueidan et al., 2011) due to the putative operculate ascus. However, the apparent operculate opening might also be diagenetic phenomenon (Lücking et al., 2009). Lücking et al., (2009) provide a comprehensive discussion concerning the placement of this fossil while recalibrating several earlier studies (Berbee and Taylor, 1993; Simon et al., 1993; Dolittle et al., 1996; Wang et al., 1999; Redecker et al., 2000; Heckman et al., 2001; Hedges et al., 2004; Padovan et al., 2005) by reassessing the systematic placement of Paleopyrenomycites. However, Berbee and Taylor (2006) convincingly showed the placement of this fossil at different positions in the Ascomycota tree (Ascomycota crown group, Pezizomycotina crown group, Sordariomycetes crown group) to have a dramatic effect on estimated ages of fungal lineages. Therefore our age estimates are best comparable to other studies using Paleopyrenomycites as constraint for the Pezizomycotina crown group (e.g., Berbee and Taylor et al., 2006; Lücking et al., 2009). Our resulting age estimates from the calibrations using Paleopyrenomycites as sole constraint are overall consistent with the ages inferred by Lücking et al. (2009; Table 4) and those of Taylor et al. (2006; calib. 2 and calib. 3 in Table 3).

Divergence times estimates obtained from the analysis that employed six internal calibration points correspond closely to those of Gueidan et al. (2011). They used Paleopyrenomycetes to calibrate the Pezizomycetes-Leotiomyceta split (which corresponds to the Pezizomycotina crown group with the exception of Orbiliomycetes) and Anzia electra for calibrating the split between Anzia and Canoparmelia. Additionally, they also utilized the metacapnodiaceous fossil and Paleocurvularia for the split of Dothideomycetes and Arthoniomycetes, together with several nonascomycotan (Taylor et al., 1994, Redecker et al., 2000, Hibbett et al., 1995, 1997), and non-fungal (Crane et al., 1995; Douzery et al., 2004) calibration constraints. Compared to their studies, our data include more ascomycotan calibration points and no external constraints, which resulted in older ages for some of the ascomycete lineages. However, the general congruence of recent studies using comparable parameter settings indicates an increase in convergence of age estimates. Our results indicate that further inclusions of reliable fossil constraints are likely to lead to even more accurate estimated ages of individual lineages. 


\subsection{Reconstruction of the evolutionary history of ascomycete lineages}

According to our results (Fig. 2), most Pezizomcotina classes originated in the Phanerozoic, while the main diversification began in the Cambrian with the divergence of Pezizomycetes (the earliest branching class of Pezizomycotina) from the remaining Pezizomycotina.

It has been assumed that the marine (Spartafora et al., 1998) and fresh water ascomycetes (Vijaykrishna et al., 2006) evolved from ancestors that occupied terrestrial habitats. Around 530 marine fungal species are known, 424 of which occur in various orders of the Pezizomycotina (mostly members of Halosphaeriales, Spartafora et al., 1998; Jones et al., 2009). Additionally, 511 freshwater fungi are known in three Pezizomycotina classes: Leotiomycetes, Dothideomycetes and Sordariomycetes (Shearer 2001; Cai et al., 2003). Because marine fungi occur in many distinct Ascomycota lineages a marine origin of the Pezizomycotina cannot be excluded (Jones et al., 2009), especially if they originated as early as our data suggests (Proterozoic).

The majority of the Pezizomycetes are terrestrial and live saprotrophically in soil. They typically build apothecia with operculate asci and it has been proposed that all other ascomata forms and spore release mechanisms have evolved from this type of fruiting body with active spore release. According to our results the Pezizomycetes diverged from other Pezizomycotina during the Cambrian. Since microbial mats including fungi were already present in the Proterozoic and fungal hyphae are known from this period (Butterfield, 2005), a Proterozoic origin of the Ascomycota and a Cambrian origin of the last common ancestor of the Pezizomycetes is conceivable. Our results suggest that the major Pezizomycotina classes (comprising the super class Letiomyceta) subsequently diverged during the Devonian. This supports a coevolutionary scenario of major land plant lineages and major Pezizomycotina lineages in the early Paleozoic. During the Devonian, the main lineages of most vascular plants (except angiosperms) appeared, and the terrestrial vegetation changed from small plants in the Early Devonian to the progymnosperm forests of Late Devonian (Meyer-Berthaud et al., 2010). This entailed the development of soils and distinct root systems, which may have onset the formation of new ecological niches of ascomycetes. Parasitic Pezizomycotina species may have evolved in aquatic or terrestrial Devonian habitats, for example together with the first plants, algae or even arthropods that were already present.

Our results also indicate an initial diversification of lichen-forming fungi (Lichinomycetes and Lecanoromycetes) in the early Carboniferous, which proceeded continuously, apparently unaffected by mass extinction events and major global climatic changes. This scenario correlates with the global development of forest ecosystems since the Carboniferous. Beyond this it is difficult to relate the development of distinct 
Pezizomycotina classes to the evolution of other organisms (plants and/or animals) since almost all classes (with the except for Orbiliomycetes and Laboulbeniomycetes), comprises a broad range of different life forms such as parasitic, lichen-forming and other symbiotic and saprophytic forms.

According to our results, the origins of many Lecanoromycetes genera reach back to the mid-Jurassic. Biatora, for instance, seems to represent an old lineage, which diverged from Bacidia and Phyllopsora some 173 million years ago (Fig. 2). The latter two genera are closely related and share similar habitat preferences, but are strictly allopatric, with Phyllopsora being restricted to tropical habitats and Biatora to temperate and cool regions of the Northern Hemisphere. Our results largely correlate with an assumed divergence of these genera about 140-170 Ma due to expansion of the Tethys Ocean separating Laurasia from Gondwana (Printzen and Lumbsch, 2000).

If we follow extant fungal lineages from the present and backwards in time we inevitably arrive at the question of how old genera could be. According to our data, most genera originated in the Mesozoic with some, like Leotia (Leotiomycetes) or Peltigera (Lecanoromycetes) extending back to the Triassic period. As the Ascomycota represents a vast group ( $\sim 64,000$ species $)$, our data set represents only a fraction of all Ascomycota species and does not allow precise interpretations of the appearances of particular genera. Additionally, we must assume that the vast majority of Phanerozoic species are extinct and thus cannot be considered in molecular analyses.

\subsection{Conclusions and Outlook}

Amber and cherts have the potential to preserve delicate structures with extraordinary quality. In this way fossil inclusions can sometimes be determined to genus level, allowing the precise assignment of the fossils to recent phylogenies. In this study we used fossil species from amber and chert that are assignable to six extant genera in three Pezizomycotina classes in order to constrain a molecular clock for a multi-gene Ascomycota phylogeny. This is the first study to evaluate the impact of internal node constraints on models of molecular evolution for the Ascomycota. Comparisons of analyses performed using multiple-fossil calibration points versus analyses using only a sole minimum age constraint (Paleopyrenomycites) show that the use of fossil age constraints (even if relatively young) in terminal groups of three Pezizomycotina classes (at the genus level) significantly affect the estimated divergence times of basal nodes and nodes of terminal groups of all Ascomycota lineages. Our estimated divergence times were exclusively based on internal age constrains (either one or six) but largely agrees with estimates in recent studies that employed external (non-ascomycotan and/or non-fungal) constraints (Berbee and Taylor 2006; Lücking et al., 2009; Gueindan et al., 2010). 
According to our results (Fig. 2) the diversification of the Pezizomycotina started in the Cambrian, proceeded continuously throughout the Phanerozoic, and was largely unaffected by mass extinction events. Lineages of extant ascomycetes typically possess a variety of different life forms in each lineage. Classes or even families of ascomycetes may comprise both, specialist and generalist species. We suggest that the diverse ecological strategies present in ascomycete lineages allowed at least some members to survive major extinction events. Such a scenario has already been suggested to explain the phenomenon that many species but only a relatively low number of genera became extinct at the Cretaceous-Paleocene boundary (Upchurch et al., 2007). Furthermore, fungal spores are likely to survive unfavorable environmental conditions at times of extinction events.

Unresolved relationships for some Pezizomycotina classes restricted comparisons of divergence times between classes belonging to the super class Leotiomyceta. Further phylogenetic studies, increased taxon sampling, and the integration of a more comprehensive fossil record will generate more reliable chronograms that will proof the hypotheses of a constant diversification of ascomycotan fungi during the Phanorozoic. An ongoing screening of newly discovered ambers and cherts (Schmidt et al., 2010a; 2012) is accumulating determinable fossils of fungi (including lichens) which are likely to further improve models of molecular evolution for fungal phylogenies, especially for individual groups of fungi.

\section{Acknowledgements}

We would like to thank Jochen Heinrichs (Munich) and Harald Schneider (London) for constructive discussions. Hans Kerp (Münster), Raymond van der Ham (Leiden) and George O. Poinar, Jr. (Corvallis) kindly provided unpublished photomicrographs of the Paleopyrenomycites, Petropus, and Parmelia fossils, respectively. We thank Volker Arnold (Heide), Christel and Hans Werner Hoffeins (Hamburg), and Jörg Wunderlich (Hirschberg and der Bergstraße) for providing amber specimens for this study. Marion Kotrba and Dieter Doczkal (Munich) kindly arranged a loan of the Stigmatomyces specimen for imaging and Vincent Perrichot (Rénnes) provided the Metacapnodiaceae fossil from Charentes amber. This study is publication number 117 from the Courant Research Centre Geobiology that is funded by the German Initiative of Excellence. 


\section{References}

Arx, J.A., 1981. The genera of fungi sporulating in pure culture, 3rd edn., J. Cramer, Vaduz.

Benton, M.J., Donoghue, P.C.J., Asher, R.J. 2009. Calibrating and constraining molecular clocks. In: Hedges, S.B., Kumar, S. (Eds.), Timetree of Life. University Press, Oxford, pp. 35-86.

Berbee, M.L., Taylor, J.W., 1993. Dating the evolutionary radiations of the true fungi. Can. J. Bot. 71, 1114-1127.

Berbee, M.L., Taylor, J.W., 2007. Rhynie chert: a window into a lost world of complex plant-fungus interactions. New. Phyt. 174, 475-479.

Berbee, M.L., Taylor, J.W., 2010. Dating the molecular clock in fungi - how close are we? Fung. Biol. Rev. 24 1-15.

Blackwell, M., 2011. The Fungi: 1, 2, 3 ... 5.1 Million Species? Am. J. Bot. 98, 426438.

Blumenstengel, H., Volland, L., Krutzsch, W., 1999. Zur Stratigraphie und Fazies des Tertiärs im Bitterfelder Raum - Referenzprofile tertiärer Ablagerungen in den Tagebauen Goitsche, Golpa-Nord und Göbern. Geologisches Landesamt SachsenAnhalt, Halle.

Brazee, N.J., Marra, R.E., Wick, R.L., 2012. Genotypic diversity of Armillaria gallica from mixed oak forests in Massachusetts. Mycologia. 104, 53-61.

Butterfield, N.J., 2005. Probable Proterozoic fungi. Paleobiol. 31, 165-182.

Cai, L., Zhang, K.Q., Hyde, K.D., 2003. Freshwater Ascomycetes. Fungal Divers. 10, 275-324.

Crane, P.R., Friis, E.M., Pedersen, K.R., 1995. The origin and early diversification of angiosperms. Nature. 374, 27e33.

Darriba, D., Taboada, G.L., Doallo, R., Posada, D., 2012. jModelTest 2: more models, new heuristics and parallel computing. Nat. Methods. 9, 772.

Doolittle, R.F., Feng, D.F., Tsang, S., Cho, G., Little, E., 1996. Determining divergence times of the major kingdoms of living organisms with a protein clock. Science. 271, 470-477.

Dörfelt, H., Schmidt, A.R., 2005. A fossil Aspergillus from Baltic amber. Mycol. Res. 109, 956-960.

Dörfelt, H., Schmidt, A.R., 2007. A conifer seedling with two herbicolous fungi from the Baltic amber forest. Bot. J. Lin. Soc. 155, 449-456.

Dornberg, A., Beaulie, J.M., Oliver, J.C., Near, T.J., 2011. Integrating fossil preservation biases in the selection of calibrations for molecular divergence time estimation. Syst. Biol. 60, 519-527.Drummond, A.J., Ho, S.Y., Rambaut, A., 2006. Relaxed phylogenetics and dating with confidence. PLoS. Biol. 4, e88. 
Drummond, A.J., Rambaut, A. 2007. BEAST: Bayesian evolutionary analysis by sampling trees. BMC Evol. Biol. 7, 214.

Drummond, A.J., Suchard, M.A., Dong Xie, Rambaut, A., 2012. Bayesian phylogenetics with BEAUti and the BEAST 1.7. Mol. Biol. Evol. 29, 1969-1973.

Dunlop, J.A., 2010. Bitterfeld amber. in: Penney, D. (Ed.), Biodiversity of fossils in amber from the major world deposits. Siri Scientific Press, Manchester, pp. 57-68. Ebersberger, I., de Matos Simoes, R., Kupczok, A., Gube, M., Kothe, E., Voigt, K., von Haeseler, A., 2012. A consistent phylogenetic backbone for the fungi. Mol. Biol. Evol. 29, 1319-1334.

Eriksson, O.E., 2005. Origin and evolution of Ascomycota-the protolichenes hypothesis. Svensk. Mykol. Tidskr. 26, 30-33.

Feldberg, K., Heinrichs, J., Schmidt, A.R., Váňa, J. Schneider, H., 2013. Exploring the impact of fossil constraints on the divergence time estimates of derived liverworts. Plant. Syst. Evol. 299, 585-601.

Floudas D. et al., 2012. The Paleozoic origin of enzymatic lignin decomposition reconstructed from 31 fungal genomes. Sci. 336, 1715-1719.Forest, F., 2009. Calibrating the Tree of Life: fossils, molecules and evolutionary timescales. Ann. Bot. 104, 789-794.

Gargas A., Taylor W.J., 1992: Polymerase chain reaction (PCR) primers for amplifying and sequencing nuclear 18S rDNA from lichenized fungi. Mycologia. 84, S. 589-592

Geiser, D.M., et al., 2006. Eurotiomycetidae and Chaetothyriomycetidae. Mycologia. 98, 1053-1064.

Gouy, M., Guindon, S., Gascuel, O., 2010. Seaview version 4: a multiplatform graphical user interface for sequence anignment and phylogenetic tree building. Mol. Biol. Evol. 27, 221-224.

Gueidan, C., Ruiba,1 C., de Hoog, S., Schneider, H., 2011. Rock-inhabiting fungi originated during periods of dry climate in the late Devonian and middle Triassic. Fungal Biol. 115, 987-96.

Hall, T.A., 1999. BioEdit: a user-friendly biological sequence alignment editor and analysis program for Windows 95/98/NT. Nucl. Acids. Symp. Ser 41, 95-98.

Ham van der, R.W.J.M., Van Konijnenburg-van Cittert, J.H.A., 2003. Rare conifers from the type area of the Maastrichtian (Upper Cretaceous Southeast Netherlands). Scr. Geol. 126, 111- 119 .

Ham van der, R.W.J.M., Dortangs, R.W., 2005. Structurally preserved ascomycetous fungi from the Maastrichtian type area (NE Belgium). Rev. Palaeobot. Palynol. 136, $48-62$.

Hawksworth, D.L., 1991. The fungal dimension of biodiversity: Magnitude, significance, and conservation. Mycol. Res. 95, 641-655. 
Hawksworth, D.L., 2001. The magnitude of fungal diversity: 1,5 million species estimated revised. Mycol. Res., 105, 1422-1432.

Heckman, D.S., Geiser, D.M., Eidell, B.R, Stauffer, R.L., Kardos, N.L., Blair, Hedges S., 2001. Molecular evidence for the early colonization of land by fungi and plants. Science. 293, 1120-1133.

Hedman, M.H., 2010. Constraints on clade ages from fossil outgroups. Paleobiol. 36, $16-31$

Hibbett, D.S., Grimaldi, D., Donoghue, M.J., 1995. Cretaceous mushrooms in amber. Nature. 377, 487.

Hibbett, D.S., Grimaldi, D., Donoghue, M.J., 1997. Fossil mushrooms from Miocene and Cretaceous ambers and the evolution of Homobasidiomycetes. Am. J. Bot. 84, 981e991.

Hibbett, D.S., et al., 2007. A higher-level phylogenetic classification of the Fungi. Mycol. Res. 111, 509-547.

Hofstetter, V., Miadlikowska, J., Kauff, F., Lutzoni, F., 2007. Phylogenetic comparison of protein-coding versus ribosomal RNA-coding sequence data: A case study of the Lecanoromycetes (Ascomycota). Mol. Phyl. Evol. 44, 412-426.

Iturralde-Vinent, M.A., 2001. Geology of the amber-bearing deposits of the Greater Antilles. Carib. J. Sci. 37, 141-167.

Iturralde-Vinent, M.A., Mac Phee, R.D.E., 1996. Age and paleogeographical origin of Dominican amber. Science. 273, 1850-1852.

Inoue, J., Donoghue, P.C.J., Yang, Z., 2010. The impact of the representation of fossil calibrations on Bayesian estimation of species divergence times. Syst. Biol. 59, 7489.

Jagt, J.W.M., 1999. Late Cretaceous-early Palaeogene echinoderms and the K/T boundary in the southeast Netherlands and northeast Belgium: Part 1. Introduction and stratigraphy. Scr. Geol. 116, 1-57.

James, T.Y., et al., 2006. Reconstructing the early evolution of Fungi using a six-gene phylogeny. Nature. 443, 818-822.

Jones, E.B.G, Sakayaroj, J., Suetrong, S., Somrithipol, S., Pang, K.L., 2009. Classification of marine Ascomycota, anamorphic taxa and Basidiomycota. Fungal Divers. 35, 1-187.

Katoh, K., Toh, H., 2008. Recent developments in the MAFFT multiple sequence alignment program. Brief Bioinform. 92, 86-98.

Kirk, P.M., Cannon, P.F., Minter, D.W., Stalpers, J.A., 2008. Ainsworth and Bisby's dictionary of the Fungi, tenth ed., CAB International, UK.

Kreader C. A., 1996. Relief of amplification inhibition in PCR with Bovine Serum Albumin or T4 Gene 32 Protein. Appl. Env. Microbiol. 62, 1102-1106. 
Kumar, T.K.A., Healy, R., Spatafora, J.W., Blackwell, M., McLaughlin, D.J., 2012. Orbilia ultrastructure, character evolution and phylogeny of Pezizomycotina. 104, 462-476.

Lara, E., Moreira, D., López-García, P., 2010. The environmental cladeLKM11and Rozella form the deepest branching clade of Fungi. Protist 161, 116-121.

Liu, Y., Steenkamp, E.T., Brinkmann, H., Forget, L., Philippe, H., Lang, F., 2009. Phylogenomic analyses predict sistergroup relationship of nucleariids and Fungi and paraphyly of zygomycetes with significant support. BMC Evol. Biol. 9, 272.

Liu, Y.J., Whelen, S., Hall, B.D., 1999. Phylogenetic relationships among Ascomycetes: evidence from an RNA Polymerse II Subunit. Mol. Biol. Evol. 16, 1799-1808.

Liu, Y.J., Hall, B.D. 2004. Body plan evolution of ascomycetes, as inferred from an RNA polymerase II phylogeny. Proc. Natl. Acad. Sci. USA 101, 4507-4512.

Lücking R., Huhndorf, S., Pfister, D.H., Plata, E.R., Lumbsch, T.H., 2009. Fungi evolved right on track. Mycologia. 10, 810-822.

Lukoschek, V., Keogh, J.S., Avise, J.C., 2012. Evaluating fossil calibrations for dating phylogenies in light of rates of molecular evolution: a comparison of three approaches. Syst. Biol. 61, 22-43.

Lumsch, T.H., 2000. Phylogeny of filamentous ascomycetes. Naturwissenschaften. 87, 335-342.

Lumbsch, T.H., Huhndorf, S.M., 2010. Myconet Volume 14. Part One. Outline of Ascomycota - 2009. Part Two. Notes on Ascomycete Systematics. Nos. 4751-5113. Fieldiana Life Earth Sci. 1, 1-64.

Lumbsch, H.T., Hipp, A.L., Divakar, P.K., Blanco, O., Crespo, A., 2008. Accelerated evolutionary rates in tropical and oceanic parmelioid lichens (Ascomycota). BMC Evol. Biol. 2008, 8, 257.

Lutzoni, F., Pagel M., 1997. Accelerated evolution as a consequence of transitions to mutualism. Proc. Natl. Acad. Sci. USA 94, 11422-11427.

Lutzoni, et al., 2004. Assembling the fungal tree of live: Progress, classification, and evolution of subcellular traits. Am. J. Bot. 91, 1446-1480.

Magallon, S.A., 2010. Using fossils to break long branches in molecular dating: a comparison of relaxed clocks allied to the origin of angiosperms. Syst. Biol. 59, 384399.

Marshall, C.R., 2008. A simple method for bracketing absolute divergence times on molecular phylogenies using multiple fossil calibration points. Am. Nat. 171, 726742.

Martínez-Delclós, X., Briggs, D.E.G., Peňalver, E., 2004. Taphonomy of insects in carbonates and amber. Palaeogeogr. Palaeoclimatol. Palaeoecol. 203, 19-64. 
Meyer-Berthaud, B., Soria, A., Decombeix, A.-L., 2010. Land plant cover in the Devonian: a reassessment of the evolution of the tree habit. In Vecoli, M., Clément, G., Meyer-Berthaud, B. (Eds.), The terrestrialisation process: modelling complex interactions at the biosphere/geosphere interface. Geological Soci. London, Spec. Public. 339, 59-70.

Miadlikowska, J. et al., 2006. New insights into classification and evolution of the Lecanoromycetes (Pezizomycotina, Ascomycota) from phylogenetic analyses of three ribosomal RNA- and two protein-coding genes. Mycologia. 98, 1088-1103.

Moncalvo, J.M., Lutzoni, F.M., Rehner, S., Johnson, J., Vilgalys, R., 2000. Phylogenetic relationships of agaric fungi based on nuclear large subunit ribosomal DNA sequences. Syst. Biol. 49, 278-305.

Morgenstern, I., Powlowski, J., Ishmael, N., Darmond, C., Marqueteau, S., Moisan, M.C., Quenneville, G., Tsang, A., 2012. A molecular phylogeny of thermophilic fungi. Fungal Biol. 116, 489-502.

Néraudeau, D., Perrichot, V., Dejax, J., Masure, E., Nel, A., Philippe, M., Moreau, P., Guillocheau, F., Guyot, T. 2002. Un nouveau gisement à ambre insectifère et à végétaux (Albien terminal probable): Archingeay (Charente-Maritime, France). Geobios. 35, 233-240.

O’Brian, B.L., Parrent J.L., Jackson J.A., Moncalvo J.M., Vilgalys, R., 2005. Fungal community analysis by large scale sequencing of environmental samples. Appl. Environ. Microbiol. 71, 5544-5550.

Ohm, et al., 2012. Diverse lifestyles and strategies of plant pathogenesis encoded in the genomes of eighteen Dothideomycetes Fungi. PLOS Pathog. 8, e1003037.

Padovan, A.C.B., Sanson, G.F.O., Brunstein, A., Briones, M.R.S., 2005. Fungi evolution revisited: application of the Penalized Likelihood Method to a Bayesian fungal phylogeny provides a new perspective on phylogenetic relationships and divergence dates of Ascomycota groups. J. Mol. Evol. 60, 726-735.

Poinar, G.O. Jr., Peterson, E.B., Platt, J.L., 2000. Fossil Parmelia in New World Amber. Lichenologist. 32, 263-269.

Parham, J.F. et al., 2012. Best Practices for justifying fossil calibrations. Systematic Biology 61, 346-359.

Perrichot, V., Néraudeau, D., Tafforeau, P., 2010. Charentese amber, in: Penney, D. (Ed.), Biodiversity of fossils in amber from the major world deposits. Siri Scientific Press, Manchester, pp. 192-207.

Printzen C., Lumbsch T., 2000. Molecular evidence for the diversification of extant lichens in the Late Cretaceous and Tertiary. Mol. Phylogenet. Evol. 17, 379-387.

Pyron, R.A., 2010. A likelihood method for assessing molecular divergence time estimates and the placement of fossil calibrations. Syst. Biol. 59, 185-195. 
Rambaut, A., 2006-2009. FigTree. Tree figure drawing tool version 1.3.1, Institute of Evolutionary Biology, University of Edinburgh (http://tree.bio.ed.ac.uk/software/figtree/).

Rambaut, A., Drummond, A.J., 2009. Tracer. MCMC Trace analysis tool version v1.5.0 (http://tree.bio.ed.ac.uk/software/tracer/).

Redecker, D., Kodner, R., Graham, L.E., 2000. Glomalean fungi from the Ordovician. Science. 289, 1920-1921.

Reeb, V., Lutzoni, F., Roux, C., 2004. Multilocus phylogenetic circumscription of the lichen-forming fungi family Acarosporaceae and its position within the Ascomycota. Mol. Phylogenet. Evol. 32, 1036-1060.

Rehner, S.A., Samuels, G.J., 1994. Taxonomy and Phylogeny of Gliocladium analyzed by large subunit rDNA sequences. Mycol. Res. 98, 625-634.

Richardson, J.B., 1967. Some British Lower Devonian spore assemblages and their stratigraphic significance. Rev. Palaeobot. Palynol. 1, 111-129.

Rice, C.M., Ashcroft, W.A., Batten, D.J., Boyce, A.J., Caulfield, J.B.D., Fallick, A.E., Hole, M.J., Jones, E., Pearson, M.J., Rogers, G., Saxton, J.M., Stuart, F.M., Trewin, N.H., Turner, G., 1995. A Devonian auriferous hot springs system, Rhynie, Scotland. J. Geol. Soc. London. 152, 229-250.

Rikkinen, J., 2003. Calicioid lichens from European Tertiary amber. Mycologia. 95, $1032-1036$.

Rikkinen, J., Poinar, G., 2000. A new species of resinicolous Chaenothecopsis (Mycocaliciaceae, Ascomycota) from 20 million year old Bitterfeld amber, with remarks on the biology of resinicolous fungi. Mycol. Res. 104, 7-15.

Rikkinen, J., Poinar, G., 2002. Fossilised Anzia (Lecanorales, lichen-forming Ascomycota) from European Tertiary amber. Mycol. Res. 106, 984-990.

Rikkinen, J., Poinar, G., 2008. A new species of Phyllopsora (Lecanorales, lichenforming Ascomycota) from Dominican amber, with remarks on the fossil history of lichens. J. Exp. Bot. 59, 5 1007-11.

Ronquist F., Huelsenbeck. J.P., 2003. Bayesian phylogenetic inference under mixed models. Bioinformatics. 19, 1572-1574.

Rossi, W., Kotrba, M.,Triebel, D., 2005. A new species of Stigmatomyces from Baltic amber, the first fossil record of Laboulbeniomycetes. Mycol. Res. 109, 271-274.

Rutschmann, F., Eriksson, T., Salim A., K, Conti, E., 2007. Assessing calibration uncertainty in molecular dating: the assignments of fossils to alternative calibration points. Syst. Biol. 56, 591-608.

Sachs, J. 1874. Lehrbuch der Botanik, fourth ed. Engelmann, Leipzig.

Sanderson, M.J., 2003a. Molecular data from 27 proteins do not support a Precambrian origin of land plants. Am. J. Bot. 90, 954-956. 
Sanderson, M.J., 2003b. R8s: inferring absolute rates of molecular evolution and divergence times in the absence of a molecular clock. Bioinformatics. 19, 301-302.

Sauquet, H., Ho, S.Y.W., Gandolfo, M.A., Jordan, G.J., Wilf, P., Cantrill, D.J., Bayly, M.J., Bromham, L., Brown, G.K., Carpenter, R.J., Lee, D.M., Murphy, D.J., Sniderman, J.M.K., Udovicic, F., 2012. Testing the impact of calibration on molecular divergence times using a fossil-rich group: the case of Nothofagus (Fagales). Syst. Biol. 61, 289-313.

Schoch, C., Shoemker, R.A., Seifert, K.A., Hambletion, S., Spatafora, J.W., Crous, P.W. 2006. A multigene phylogeny of the Dothideomycetes using four nuclear loci. Mycologia. 98, 1041-1052.

Schoch et al., 2009. The Ascomycota Tree of Life: A Phylum-wide Phylogeny Clarifies the Origin and Evolution of Fundamental Reproductive and Ecological Traits. Syst. Biol. 58, 224-239.

Schmidt, A.R., Beimforde, C., Seyfullah, L.J., Wege, S.E., Dörfelt, H., Girard, V., Grabenhorst, H., Gube, M., Heinrichs, J., Nel, A., Nel, P., Perrichot, V., Reitner, J., Rikkinen, J., (in review). Amber fossils of sooty moulds. Rev. Palaeobot. Palynol.

Schmidt et al., 2010a. Cretaceous African life captured in amber. Proc. Natl. Acad. Sci. 107, 7329-7334

Schmidt A.R., Dörfelt, H., Struwe, S., Perrichot, V. 2010b. Evidence for fungivory in Cretaceous amber forests from Gondwana and Laurasia. Palaeontographica. 283, $157-173$.

Schwarz, G., 1978. Estimating the dimension of a model. Ann. Stat. $6461-464$,

Shearer, C.A., 2001. The distribution of freshwater filamentous Ascomycetes. In: Misra, J.K., Horn B.W., (Eds.), Trichomycetes and other fungal groups: Robert W. Lichtwardt Commemoration Volume. Science Publishers Inc. Enfield, New Hampshire, pp. 225-292.

Simon, L., Bousquet, J., Levesque, R.C., Lalonde, M., 1993. Origin and diversification of endomycorrhizal fungi and coincidence with vascular land plants. Nature 363, 6769.

Spatafora, J. W, Volkmann-Kohlmeyer, B., Kohlmeyer, J., 1998. Independent terrestrial origins of the Halosphaeriales (Marine Ascomycota). Am. J. Bot. 85, 1569-1580.

Spatafora, J.W., et al., 2006. A five-gene phylogenetic analysis of the Pezizomycotina. Mycologia. 98, 1020-1030.

Stadler, T., 2009. On incomplete sampling under birth-death models and connections to the sampling-based coalescent. J. Theor. Biol. 261, 58-66.

Stamatakis, A., Hoover, J., Rougemint, J., 2008. A Rapid Bootstrap Algorithm for the RAxML Web Servers, Syst. Biol. 75, 558-771.

Standke, G., 1998. Die Tertiärprofile der Samländischen Bernsteinküste bei Rauschen. Schriftenreihe für Geowissenschaften. 7, 93-133. 
Stankiewicz, B.A., Poinar, H.N., Briggs, D.E.G., Evershed, R.P., Poinar, G.O. Jr., 1998. Chemical preservation of plants and insects in natural resins. Philos. T. Roy. Soc. B. 265, 641-647.

Steenkamp, E.T., Wright, J., Baldauf, S.L., 2006. The Protistan Origins of Animals and Fungi. Mol. Biol. Evol. 23, 93-106.

Taylor, J.W., Berbee, M.L., 2006. Dating divergences in the Fungal Tree of Life: review and new analyses. Mycologia. 98, 838-49.

Taylor, T.N., Remy, W., Hass, H., 1994. Allomyces in the Devonian. Nature. 367, 601.

Taylor, T.N., Hass, H., Kerp H., 1999. The oldest fossil Ascomycete. Nature. 399, 648.

Taylor, T.N., Klavins, S.D., Krings, M., Taylor, E.L., Kerp, H., Hass, H., 2004. Fungi from the Rhynie chert: a view from the dark side. Trans. R. Soc. Edinb. Earth Sci. 94, 457-473.

Taylor, T.N., Hass, H., Kerp, H., Krings, M., Hanlin, R.T., 2005. Perithecial ascomycetes from the 400 million year old Rhynie chert: an example of ancestral polymorphism. Mycologia. 97, 269-285.

Thell, A., Crespo A., Divakar, P.K., Kärnefelt, I., Leavitt, S. D., Lumbsch, T.H., Seaward, M.R.D., 2012. A review of the lichen family Parmeliaceae - history, phylogeny and current taxonomy. Nord. J. Bot. 30, 641-664.

Tibell, L., 2001. Photobiont association and molecular phylogeny of the lichen genus Chaenotheca. Bryologist. 104, 191-198.

Tibell, L., Wedin, M., 2000. Mycocaliciales, a new order for nonlichenized calicioid fungi. Mycologia. 92, 577-581.

Tibell, L., Koffman, A., 2002. Chaenotheca nitidula, a new species of calicioid lichen from Northeastern North America. Bryologist. 105, 353-357

Tuovila, H., Schmidt, A.R., Beimforde, C., Dörfelt, H., Grabenhorst, H., Rikkinen, J., 2013 Stuck in time - a new Chaenothecopsis species with proliferating ascomata from Cunninghamia resin and its fossil ancestors in European amber. Fungal Divers. 58, 199-213.

Vijaykrishna, D., Jeewon, R., Hyde, K.D., 2006. Molecular taxonomy, origins and evolution of freshwater ascomycetes. Fungal Dives. 23, 351-390.

Vilgalys, R., Hester, M., 1990. Rapid genetic identification and mapping of enzymatically amplified ribosomal DNA from several Cryptococcus species. J. Bacteriol. 172, 4238-4246.

Webster, J., Weber, R., 2009. Introduction to fungi, third ed. University Press, Cambridge, UK.

Wedin, M., Tibell, L., 1997. Phylogeny and evolution of Caliciaceae, Mycocaliciaceae and Sphinctrinaceae (Ascomycetes), with notes on the evolution of the prototunicate ascus. Can. J. Bot. 75, 1236-1242. 
Wilkinson, R.D., Steiper, M.E., Soligo, C., Martin, R.D., Yang, Z.H,, Tavaré, S., 2011. Dating primate divergences through an integrated analysis of palaeontological and molecular data. Syst. Biol. 60, 16-31.

Woolfit M., Bromham L., 2003. Increased rates of sequence evolution in endosymbiotic bacteria and fungi with small effective population sizes. Mol. Biol. Evol. 20, 15451555 .

\section{Supporting Information: Figure S1}

Fig. S1. Maximum clade credibility (MCC) tree obtained from a Bayesian approach (BEAST) using Paleopyrenomycites as minimum age constraint for Pezizomycotina crown group (indicated by a red circle). The chronogram pictures a part of the Ascomycota phylogeny showing divergence time estimates for Pezizomycotina in millions of years (Ma), with bars indicating the $95 \%$ highest posterior densities (HPD). Estimated ages for numbered nodes are available in Table 3. Numbers at nodes indicate posterior probabilities for node support (pp). Geological periods are abbreviated as: Cam. $=$ Cambrian, Ord. $=$ Ordovician, Carb. $=$ Carboniferous, Perm. $=$ Permian .

[Figure also contains the abbreviations "Prot-Pal.", "Pal-Mes", and "Mes-Cen", plus a few cartooned clades. See comments in PDF. Include explanations above, please] 


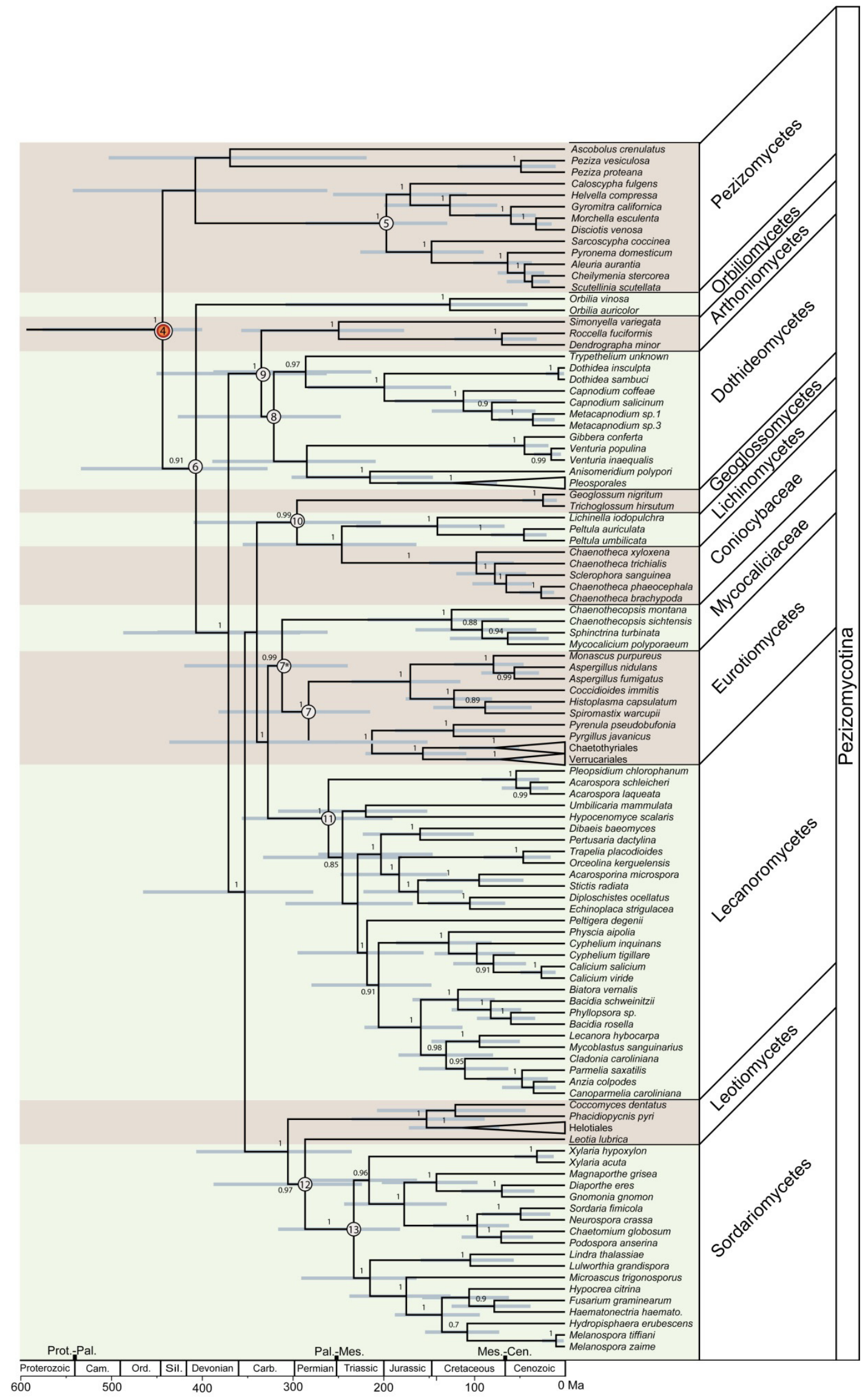





\section{Curriculum Vitae}

Christina Beimforde

Geburtstag und Geburtsort: 06.12.1977 Lohne, Deutschland

Nationalität: deutsch

Studium

1999-2006 Studium der Biologie an der Carl von Ossietzky Universität Oldenburg

2006 Diplomarbeit zum Thema "Einfluss von Restaurierungsmitteln auf gesteinsbesiedelnde mikrobielle Vergesellschaftungen: mikroskopischer und molekularbiologischer Vergleich"

2007-2008 Mitarbeiterin in der Abteilung Geobiologie der Georg-August-Universität Göttingen; Forschungsthema: mikrobielle Besiedlung von Bernstein und ihre Auswirkungen (Biodeterioration)

Nov. 2008 Promotionsstudium in der Nachwuchsgruppe "Die Evolution der Landpflanzen und die Entwicklung terrestrischer Ökosysteme" im Courant Forschungszentrum Geobiologie der Georg-August-Universität Göttingen

\section{Publikationen}

Beimforde C, (2011) Biodeterioration (of Stone). In: Reitner J. \& Thiel V. (eds), Encyclopedia of Geobiology, Springer-Verlag, Heidelberg, pp 112-117.

Beimforde C, Schmidt AR (2011) Microbes in Resinous Habitats: A compilation from modern and fossil resins. In: Reitner J, Queric N-V, Arp G (eds), Advances in Stromatlite Geobiology. Lecture Notes in Earth Sciences. 131, 391-407.

Beimforde C, Schäfer N, Dörfelt H, Nascimbene PC, Singh H, Heinrichs J, Reitner J, Rana RS, Schmidt AS (2011) Ectomycorrhizas from a Lower Eocene angiosperm forest. New Phytologist 192, 988-996.

Beimforde C, Feldberg K, Nylinder S, Rikkinen J, Tuovila H, Dörfelt H, Gube M, Jackson D, Reitner J, Seyfullah LJ, Schmidt AR, (submitted). Estimating the Phanerozoic history of the Ascomycota lineages: combining fossil and molecular data. Molecular Phylogenetics and Evolution.

Sadowski E-M, Beimforde C, Gube M, Rikkinen J, Singh H, Seyfullah LJ, Heinrichs J, Nascimbene PC, Reitner J, Schmidt AR, (2012) The anamorphic genus Monotosporella (Ascomycota) from Eocene amber and from modern Agathis resin. Fungal Biology 116, 1099-1110. 
Schmidt AR, Beimforde C, Seyfullah LJ, Wege SE, Dörfelt H, Girard V, Grabenhorst H, Gube M, Heinrichs J, Nel A, Nel P, Perrichot V, Reitner J, Rikkinen J, (in review). Amber fossils of sooty moulds. Review of Palaeobotany and Palynology.

Tuovila H, Schmidt AR, Beimforde C, Dörfelt H, Grabenhorst H, Rikkinen J, (2013) Stuck in time - a new Chaenothecopsis species with proliferating ascomata from Cunninghamia resin and its fossil ancestors in European amber. Fungal Diversity 58, 199-213.

\section{Tagungsbeiträge}

Beimforde C, Schmidt AR (2009). Vortrag: Fossile und rezente Harze als Lebensräume. Jahrestagung der Paläontologischen Gesellschaft, Bonn, 5.-7. Oktober 2009.

Beimforde C, Schmidt AR (2009). Posterbeitrag: Mesozoic and Recent Resins as Habitats of Microorganisms. Posterpräsentation: 10th International Symposium on Mesozoic Terrestrial Ecosystems and Biota, Teruel (Spanien), 14.-21. September 2009.

Beimforde C, Quéric N-V, Reich M, Reitner J (2008). Posterbeitrag. Microbial diversity in and on Baltic and Bitterfeld amber. In: Löffler, S.-B. \& Freiwald, A. (eds), Jahrestagung der Paläontologischen Gesellschaft, Erlangen, September 8.10.2008. Erlanger Geologische Abhandlungen, Sonderband 6, 76.

Beimforde C, Dörfelt H, Girard V, Grabenhorst H, Muschalla M, Reitner J, Rikkinen, J, Schmidt AR (2010). Posterbeitrag. Fossile Rußtaupilze in mesozoischen und känozoischen Bernsteinen. In: Wörheide G, Krings M (eds), 80. Jahrestagung der Paläontologischen Gesellschaft, München, 5.-8. Oktober 2010. Zitteliana, Series B 29, 21.

Beimforde C, Dörfelt H, Reitner J, Schmidt AR (2010) Amber and modern resins as habitats of microorganisms. Vortrag. FossilsX3: Insects, Arthropods, Amber, Capital Normal University, Beijing, China, 20. -25. August 2010, Abstracts 113.

Beimforde C, Feldberg K, Tuovila H, Rikkinen J, Gube M, Seyfullah JL, Dörfelt H, Reitner J, Schmidt AR (2013). Vortrag. The potential of fossils preserved in amber for calibrating the molecular clock: An estimation of the Phanerozoic history of the Ascomycota. Southern lands and southern oceans: life on the edge. VII Southern Connection Congress Dunedin, New Zealand, 21.-25. Januar 2013, Abstracts, pp. 9.

König J, Beimforde C, Reitner J, Schmidt AR (2010). Fossile Prokaryoten in mesozoischen und känozoischen Bernsteinen. In: Wörheide G, Krings M (eds) 80. Jahrestagung der Paläontologischen Gesellschaft, München, Germany, 5.-8. Oktober 2010. Zitteliana, Series B 29, 60. 
Schmidt AR, Beimforde C (2008). Fossil and Recent microbial associations from amber. In: Reitner J, Quéric N-V, Reich M. (eds) Geobiology of stromatolites. International Kalkowsky-Symposium, October 4-11, 2008, Abstracts, pp. 117-118. Universitätsverlag Göttingen.

Schmidt AR, Beimforde C, Dörfelt H, Nascimbene PC, Nel A, Nel P, Schäfer N, Singh, H, Wappler T (2011). New Ascomycota from Eocene forests and their interactions with plants and arthropods. In: Lehmann T, Schaal SFK (eds) The World at the Time of Messel: Puzzles in Palaeobiology, Palaeoenvironment, and the History of Early Primates. 22 ${ }^{\text {nd }}$ International Senckenberg Conference. 15.- 19. November 2011, Frankfurt am Main. Conference Volume, Senckenberg Gesellschaft für Naturforschung, Frankfurt am Main, pp. 149-150.

Seyfullah LJ, Beimforde C, Perrichot V, Rikkinen J, Schmidt AR (2012). The what and why of amber: attempting to understand the relationship between resin production and amber deposits. In: Witzmann, F. \& Aberhan, M. (eds) Centenary Meeting of the Paläontologische Gesellschaft. Programme, Abstracts, and Field Guides, September 24-29, 2012, Museum für Naturkunde Berlin, Germany. Terra Nostra März 2012, 166-167.

Seyfullah LJ, Beimforde C, Perrichot V, Rikkinen J, Schmidt AR (2012). Resin production in Araucariaceae: enlightening amber deposition? International Organization of Paleobotany Congress, Tokyo, August 2012. Japanese Journal of Palynology 58, 210.

Seyfullah LJ, Beimforde C, Perrichot V, Rikkinen J, Schmidt AR (2012). Sticky moments - understanding amber preservation through modern resin studies. Linnean Society Palaeobotany specialist group meeting. October 2012. Abstract vol. p. 6.

Seyfullah LJ, Beimforde C, Perrichot V, Rikkinen J, Schmidt AR (2012). Understanding amber deposits through modern resin studies. Palaeontological Association Annual Meeting, Dublin, Dezember 2012, Palaeontological Association Newsletter 81, 49.

Seyfullah LJ, Beimforde C, Perrichot V, Rikkinen J, Schmidt AR (2013). Southern Hemisphere forests shedding light on reasons for amber accumulations. In: Dickinson K, Lee, B (eds) VII Southern Connection Congress 2013, Dunedin, New Zealand, 21-25 Januar 2013. Southern lands and southern oceans: life on the edge? Programme and abstracts, p. 116.

Seyfullah LJ, Beimforde C, Perrichot V, Rikkinen J, Schmidt AR (2013). Why do we have amber forests? Using modern studies to attempt to understand the relationship between resin production and amber deposits. Bitterfeld amber colloquium. 